\title{
THE CONSTITUTIONAL AND PARLIAMENTARY HISTORY OF IRELAND [ST TILL THE UNION [82
}

J.G.SWIFT MACNEILL,M.P 


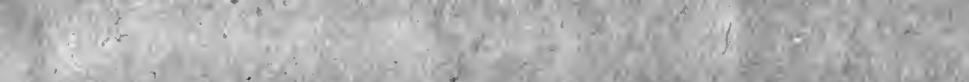

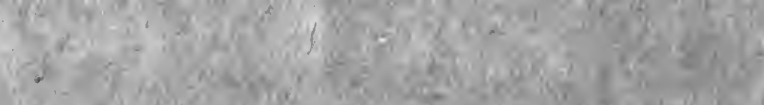

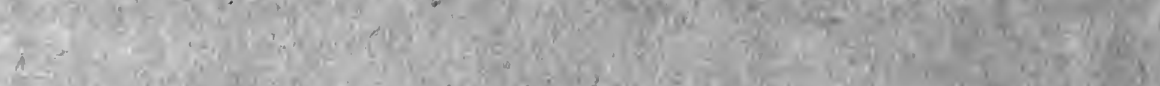

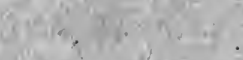

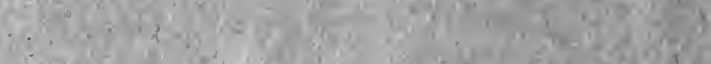

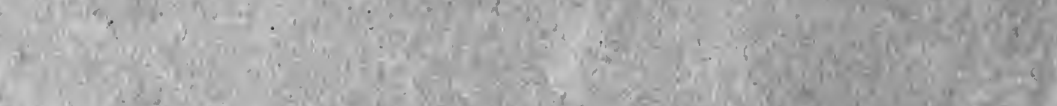

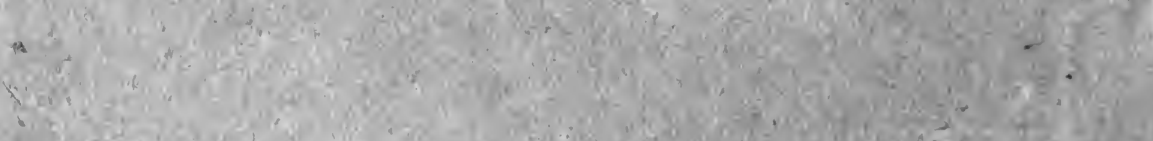

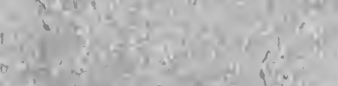
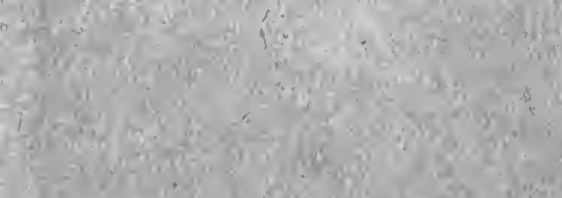

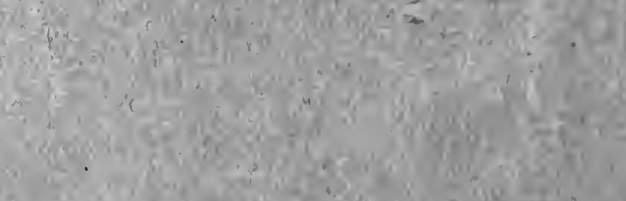

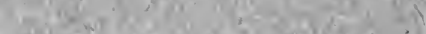

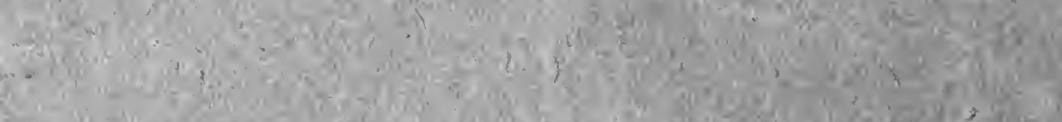

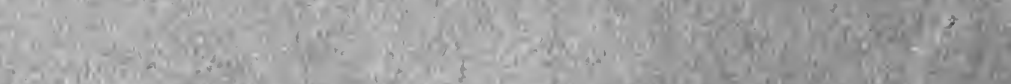

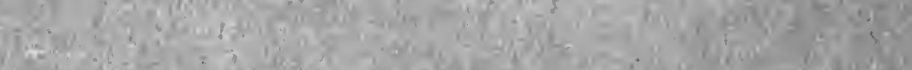

(a)

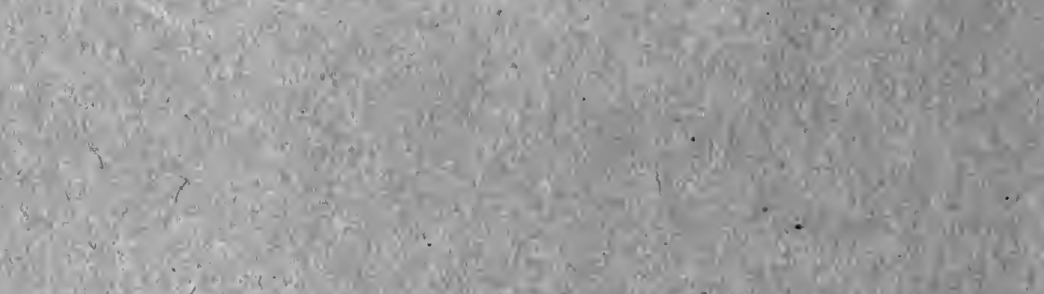

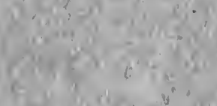

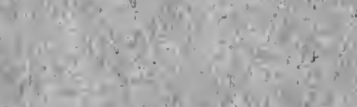

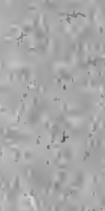

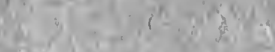
Whe

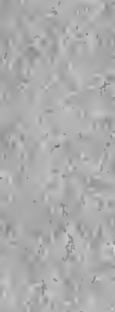

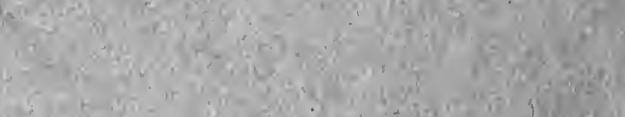

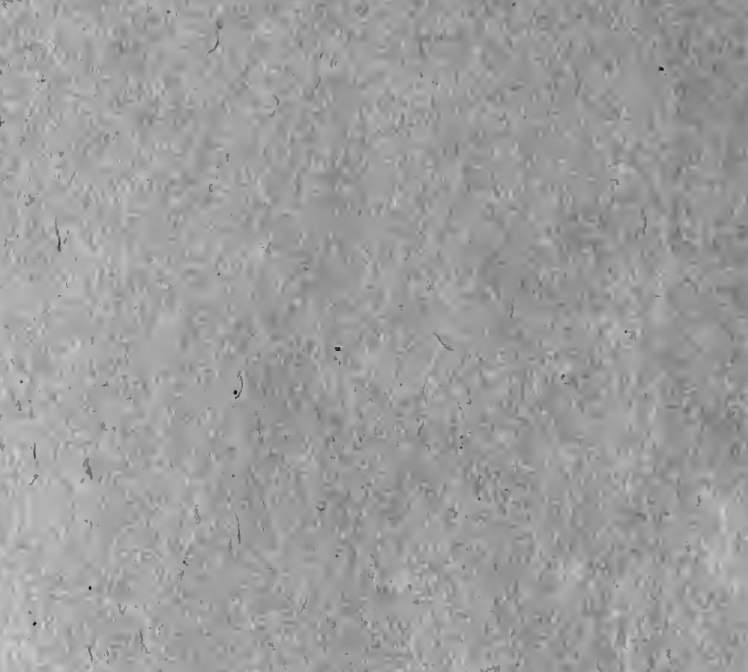

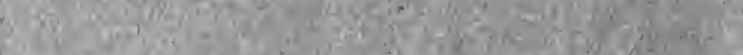

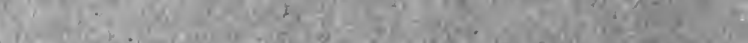

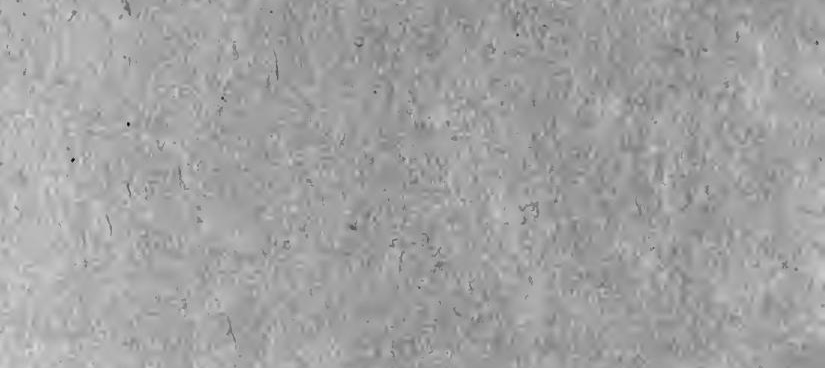

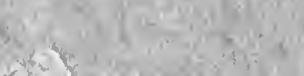




THE

CONSTITUTIONAL AND

PARLIAMENTARY

HISTORY OF IRELAND

TILL THE UNION 



\section{THE \\ CONSTITUTIONAL AND \\ PARLIAMENTARY \\ HISTORY OF IRELAND \\ TILL THE UNION}

BY

J. G. Swift MacNeill, M.P.

M.A.. Christ Church, Oxford.

One of His Majesty's Counsel in Ireland.

Dean of the Faculty of Law,

Professor of Constitutional Law and the Law of

Public and Private Wrongs, and

Clerk of Convocation, National University of Ireiand.

Formerly Professor of Constitutional and

Criminal Law in the Honourabie

Society of the King's Inns

Dublin

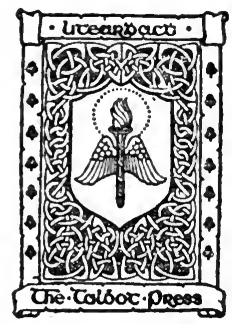

$$
\frac{152130}{6-9-19}
$$

DUBLIN
THE TALBOT PRESS
89 TALBOT STREET

\section{LONDON}

T. FIISHER UNWIN

('LIMITIED)

11 ADELPHI TERRACE

1917 


\section{DEDICATE THIS BOOK}

TO MY SISTER,

MARY CoLPOYS DEANE MACNEIL,

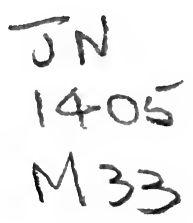




\section{PREFACE}

I purpose in this book to give a general view of the leading facts and characteristics of Irish Constitutional and Parliamentary History before the passing of the Act of Union.

I have endeavoured to present, in a comparatively small compass, such a description of the Irish Parliament and the working of governing institutions in Ireland as will place within easy reach and in handy form information of the salient features of the rise and progress of the Irish Constitution, just as information of the salient features of the rise and progress of the British Constitution, of which the Irish Constition was first a counterpart and subsequently an inversion, is within easy reach and in handy form.

Persons well informed in public affairs are not infrequently lacking in knowledge, however

$$
\checkmark .
$$


vi.

superficial, of the Constitutional and Parliamentary History of Ireland-a subject of the very highest interest in itself, acquaintance with which is moreover certain to be of incalculable value in the successful working of the Irish Legislative System of the future. Mr. Gladstone's advice in a letter in 1886 addressed primarily to a public man of the time, "Study Irish History," is of the very widest application. It has not lost its force, nor has the need of its adoption been modified after the lapse of upwards of a generation.

While I hope that these pages, written with the object I have indicated, may be useful to the student and to the general reader alike, I indulge in a still higher ambition-that the perusal of this work, in which references to the authorities which form its basis have been carefully given, may induce a taste for historical research, or may at least encourage and foster a zeal for the systematic study of Mr. Lecky's writings on Irish History, which will in itself be an epoch in the reader's intellectual life. 
The scheme of the book is very simple. Having set to myself the task of endeavouring to narrate the principal representative facts of Irish Constitutional and Parliamentary History, I have thus attempted to achieve my object. I have reproduced in the Introduction $M r$. Butt's speech addressed to a popular but highly representative audience, and avowedly designed as an exposition to the whole English speaking world of the constitution and powers of the Irish Parliament, and of the epochs of Irish Constitutional and Parliamentary History. That speech I have taken for my text, and on that text I have enlarged in the succeeding chapters of the book.

I recognise fully that readers of an historical treatise in the formation of their judgments should use as a corrective the "personal equation" of the writer. In this connection the trend of thought and the bias, however unconscious, of one who, like myself, has been for upwards of thirty years closely associated with a political movement founded on past history as 
viii.

much as on present conditions, cannot be ignored. " "There is nothing," a great man once observed to me, "less difficult than to be fair, but nothing more difficult than to appear so." In my endeavour not only to be fair but to appear so I have, eschewing originality, largely allowed the facts and the authorities by which they are supported to speak for themselves. I have moreover, as the frequent references to 'Mr. Lecky's writings show, stated on many occasions facts in $M r$. Lecky's own words and reproduced his judgments upon them, judgments which, if pronounced by me might be discounted as the utterances of a party man committed to certain political doctrines, but must be considered from a far different point of view as the mature judicial conclusions formed, to use a favourite expression of Mr. Lecky's, " in the cool light of history," by one of the foremost protagonists of his generation in the defence and maintenance. of the Union.

I have aspired, despite the tyranny of space, 
by quoting from Parliamentary debates, contemporary authors, the correspondence between Lords Lieutenant and Chief Secretaries on the one hand, and the representatives of the British Cabinets on the other, at presenting the views, characters and moral environment of men actually conversant with the practice of the Irish Constitution in whose working they were, or had been, actively engaged.

The limitations which I have imposed on myself have prevented the inclusion of matters not directly affecting the Constitutional and Parliamentary History of Ireland. In the 'Appendix, however, I have transgressed these narrow bounds in some instances. In Note $A$. I have stated some points of the law, custom and etiquette of the Irish Parliament; in Note $B$. I have sketched the efforts of that Parliament, despite appalling discouragements, to promote the material prosperity of the country; and in Note C. I have reproduced an Address I delivered in 1911 to the Eighty Club in the Irish Parliament House in Dublin on Irish Parliamentary life. 
X.

If these pages, written at intervals and amid many distractions, contribute in any degree to the promotion of the study of Irish History, with the great benefits to the people, not of these countries only, but of the whole British Empire, accruing therefrom, I shall be content and thankful.

Dublin, Sepiember, 1917. 


\section{CONTENTS}

CHAP.

INTRODUC'TION (INCI,UDING ISAAC BUTT'S SPELCH) xiii.

I. THF IRISH PARIIAMENT AND THE CLAIM OI THF BRITISH PARI,IAMHNT TO LIGISIATE

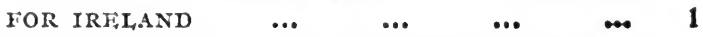

II. POYNINGS' IAW AS ATIECTING THE IRISH

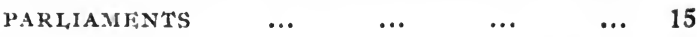

III. THE COMPOSITION OF THE IRISH PARIIAMENT 30

IV. THE IRISH PARI,IAMENT AND THE IRISH I,AND

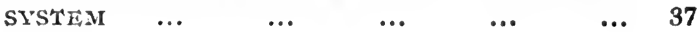

V. FARI, STRUGGI,ES IN THE IRISH PARIIAMENT FOR POPUIAR RIGH'TS $\quad \ldots \quad \ldots . \quad \ldots \quad 47$

VI. THE, IRISIT PARIIAMENT OF $1689 \quad \ldots \quad \ldots \quad \ldots \quad 59$

VII. THE IRISH PARIIAMEN'T AS AFFECTLD BY PUBLIC

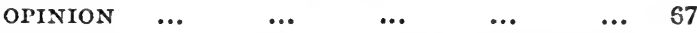

VIII. THE RISE AND PROGRESS OF PARI,IAMFNTARY OPPOSITION IN IRELAND $\ldots \quad \ldots \quad \ldots \quad \ldots$

IX. THE FIGH'T FOR I,IBERTY AGAINST CORRUPTION 103

X. THE METHOD OF SHCURING A PARI,IAMENTARY MAJORITY FOR THE GOVERNMENT ... $\quad \ldots 119$

XI. THE IRISH PARIIAMENT AND A SINISTER ADMINISTRATION $\quad \ldots \quad \ldots . \quad \ldots \quad \ldots 127$

XII. THE IRISH PARI,IAMENT AND PRESSURF FROM WITKOUT $\ldots . \quad \ldots \quad \ldots \quad \ldots$

XIII. THE IRISH PARLIAMENT AS AFFECTID BY THE VOIUNTEER MOVEMENT $\quad \ldots \quad \ldots$

XIV. THF TRIUMPH OF GRATTAN AND THE VOLUNTERS $\quad \ldots \quad \quad \ldots \quad \ldots 171$

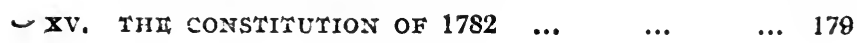


xii. CONTEN'TS

CHAP. PAGE

XVI. THE IRISH PARIIAMENT AND THE VOLUNTEER CONVENTION

$J$ XVII. THE IRISH PARIIAMENT AND "ORDE'S COMMERCIAL PROPOSITIONS” $\ldots \quad$... $\quad$.. 205

XVIII. THE IRISH PARLIAMENT AND THR REGENCY QUESTION $\ldots \quad \ldots \quad \ldots \quad \ldots \quad \ldots \quad \ldots 218$

$J$ XIX. THE AGITATION FOR PARLIAMENTARY REFORM AND THE RFMOVAL, OF CATHOLIC DISABILITIEAS 227

$\checkmark \mathrm{XX}$. THE FITZWILLIAM EPISODE $\quad \ldots \quad \ldots \quad \ldots \quad \ldots 249$

XXI. THE OPPOSITION OF THE BRITISH GOVERNMENT TO IRISH PARIIAMENTARY REFORM AND CATHOLIC EMANCIPATION ... $\quad . . \quad \ldots 271$

XXII. AN UNREFORMED AND CORRUPT PARLIAMENT AND COERCIVE LEGISIATION $\quad \ldots \quad \ldots 282$

XXIII. THA INSURRECTION OF 1798 AND ITS BEARING

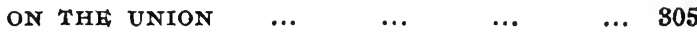

XXIV. PREPARING THE IRISH PARLIAMENT FOR THE $\begin{array}{lllllll}\text { UNION } & \ldots & \ldots & \ldots & \ldots & \ldots & 318\end{array}$

XXV. DEFEAT OF THE PROPOSAL OF THF UNION IN THE IRISH PARLIAMENT, 1799 .. $\quad \ldots 333$

XXVI. MAKING A PARIIAMENTARY MAJORITY FOR THE UNION

XXVII. THE CARRYING OF THE UNION THROUGH THE IRISH AND THE BRITISH PARLIAMENTS $\quad \ldots 883$

Note A-Laws, Customs, Usages, and Etiquette of the Irish Parliament $\quad \ldots \quad$... $\quad \ldots . \quad \ldots \quad 399$

Noty B-The Irish Parliament and Material Prosperity 437 Note C-A Sketch of Irish Parliamentary Life $\quad . .453$

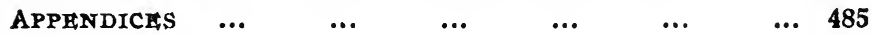
$\begin{array}{llllllll}\text { INDEX } & \ldots & \ldots & \ldots & \ldots & \ldots & \ldots & 507\end{array}$ 


\section{INTRODUCTION.}

WRITERS of historical treatises have not infrequently concluded their works by a summary of the results of their studies. I propose to adopt a different course, and to present to my readers an outline of the period to which I will invite their attention in detail in the following pages. That outline gives a brief but comprehensive view of the rise and development of Parliamentary institutions in Ireland, of the relations of the Parliaments of Ireland to the Parliaments of England, and subsequently to the Parliaments of Great Britain ; and of the relations of the Irish and British Governments to each other till the Legislative Union. A summary of such a character is ready to my hand. It is contained in the sketch of the rise and progress of the Irish Constitution by the late Mr. Isaac Butt in his statement at the Home Rule Conference in Dublin on the 18 th November, 1873 , in which he proposed the scheme for the re-establishment of a Parliament for Ireland to which the Home Rule movement in its present form owes its existence. Mr. Butt, who was a man of profound political genius, and one of the greatest constitutional lawyers of his own or of any generation, was, no doubt, in this outline of 
Irish Parliamentary and Constitutional history, speaking as a political leader, not as an historical student. His statement, however, deals with facts and not with theories, and his description of the history, constitution, and powers of the Irish Parliament, in his speech at the Home Rule Conference in I873, is in remarkable accord with his description of the history, constitution, and powers of that Parliament, when speaking, not as an advocate of the restoration of Parliamentary institutions in Ireland, but as the leading opponent of Mr. O'Connell, in $18_{43}$, in the debate on Repeal of the Union in the Corporation of Dublin. I examined both speeches very carefully, and directed Mr. Butt's attention to their absolute agreement in exposition of the history of the Irish Parliaments, which he acknowledged with gratification, stating that $\mathrm{Mr}$. O'Connell had said openly in the course of debate that Ireland would, in the future-Mr. Butt was then only in his thirtieth year-have in Mr. Butt a defender of Irish National rights, while he said to him in private that he would sooner or later be a great leader of the Irish Nation. Mr. Butt's outline of the history of the Irish Parliaments, which is unaffected by his political position in 1843 as an opponent of the Repeal of the Union, and in 1873 as an expounder of Home Rule, may be safely accepted as accurate and as an introduction to this work.

" From the very earliest introduction," said Mr. Butt, of the power of the English Kings in Ireland, the Irish, who submitted to the rule of those Kings, had a right to 
the same Parlianientary constitution as that which England enjoyed. No matter how that power was established, whether by right of conquest, as English writers have chosen to assert, or, as Irish writers have said, by the voluntary submission of some Irish chiefsfrom the day when, first at Lismore, and afterwards in Dublin, King John declared that the Irish people were to have the benefit of the great Charter and of English law-it became an essential part of the Union between Ireland and the English Crown, that the Sovereign should govern us-as in England-by the advice of a National Assembly. English power but slowly reduced the whole island to submission. During the process our Parliaments were but Parliaments of the Engiish Pale. It was not until the reign of James $I$. that the constitution of the Irish House of Commons was settled on a basis professing to embrace the entire island. At that time the English Sovereigns had not surrendered the power which, in the early times of Parliamentary history, they certainly possessed-that of enfranchising towns, and conferring on them the right, or rather imposing the duty-it was once deemed a burdensome duty-of sending representatives to the House of Commons. King James, after the Settlement of Ulster, exercised this power of enfranchising boroughs. These boroughs were in its last struggle the weakness - they were always the corruption-of the Irish Parliament. But, at all events, they completed the Parliamentary system of Ireland, a system which continued unaltered until, by the Act of Union, it was finally destroyed. In the 17 th century, from the accession of James to that of William III., the action of Irish Parliaments was more or less interrupted by wars and revolutions. From the Battle 
of the Boyne to the Union, an Irish Parliament regularly met upon the basis that was settled in the days of James. It was constituted according to English law. It had, like the English Parliament, its hereditary House of Peers. Its House of Commons was elected exactly like the English House of Commons, by the freeholders of the counties and by cities and towns, deriving their right to return Members from the Charters of Kings. In the two countries the laws regulating the Parliamentary Franchise were exactly the same. The Freehold Franchise was the same in both; and the Royal Charters had exactly the same effect, and were construed and tried by the same rules of law. Close boroughs had existed in England as in Ireland, although not so numerously in proportion to the other elements of representation.

"The Irish Parliament consisted of three hundred Members. Of these, sixty-four were returned by the forty-shilling freeholders of the thirty-two counties; two were sent by the University of Dublin; sixty-two were elected by the counties of the cities or towns in which the Freeholder Franchise existed, or by boroughs possessing more or less of popular franchises. Of the three hundred Members, only one hundred and twentyeight were chosen by the shadow of a popular election. The remaining one hundred and seventy-two were absolutely the nominees either of the English Government or of persons who held the power of nomination as their private property-in some instances, of English noblemen ; in many instances, of absentee proprietors ; in four instances, at least, of the Bishops of the Irish Established Church; not by Irish Bishops, but by Bishops sent here to serve the English interest, like Cleaver at Kilkenny, or Boulter and Stone at Armagh. 
" The records of the awards of compensation to private proprietors for boroughs extinguished at the Union abundantly established these facts. Eighty-four boroughs were treated as private property, and compensation given for that property to their patrons.

"Such was the constitution of the Irish Parliament. Let me briefly glance at its position and its powers.

"It was always an admitted principle of the Constitution that the Crown of Ireland was appendant and inseparably annexed to the Imperial Crown of England. Mr. O'Connell stated this, in very strong, but, after all, scarcely exaggerated, language when he said that whoever was King de facto in England was King de jure in Ireland. This much, at least, is unquestionable, that if, by any legitimate authority, a right was acquired to the Crown of England, the person who became King of England was de jure Sovereign of Ireland. When the succession to the English Crown was altered by the Act of the English Parliament, excluding the heirs of Charles I., and setting the Crown upon the descendants of the Princess Sophia, no corresponding Act was ever passed by the Irish Parliament. It was admitted that the English Parliament, in disposing of the English Crown, disposed, at the same time, of the appendant Crown of Ireland. Their power to do so was never questioned -it was distinctly recognised. The title of the House of Hanover to the Crown of Ireland rested solely on a statute of the English Parliament.

"From this admitted dependence of the Crown of Ireland upon that of England arose the claim of the English Parliament to legislate for Ireland. Over all the colonies and dependencies of the British Crown, the British Parliament had exercised the right of legis- 
xviii.

lation. Over Ireland they asserted the same right. I need not tell you how fiercely it was contested, and that it was finally abandoned in 1782 . But up to 1782 the right was asserted and occasionally exercised.

"This claim was disputed. But there was another consequence of the dependence of the Irish Crown, which was not so. The Sovereign of England, in all matters of his foreign relations, in all questions of peace and war, was advised solely by his English Privy Council, by his English Parliament, and by English Ministers, responsible only to that Parliament, but all his acts done under this advice bound Ireland. I will presently ask your attention more particularly to the effect of this under the arrangement of 1782 .

" To complete our view of the position of the Irish Parliament, we must remember that by an Act of Parliament itself, a most important restriction was placed upon its legislative powers. By an Irish Act of Parliament, passed in the reign of Henry VII., in the year 1495, it was enacted that no Bill should be presented in the Irish Parliament until the heads of that Bill had been submitted to the English Privy Council, and certified as approved of under the Great Seal of England. This law is known as Poynings' Law, from the name of the person who was Lord Deputy when it was passed. This law was a matter entirely distinct from any claim of the English Parliament to legislate for Ireland; it was a law of the Irish Parliament itself, passed by the King, Lords and Commons of Ireland, deriving its authority from a source entirely independent of the English claim, and continuing in force when that claim was abandoned. The original law required the assent of the English Privy Council to be given to the intended 
Bill before Parliament met. In the reign of Queen Mary it was modified so as to admit of that assent being given while Parliament was sitting; but that assent was still necessary to authorise the introduction of the Bill. With this modification the Law of Poynings continued in force up to 1782 .

"Such was the position of the Irish Parliament in the interval between the Revolution and 1782. I trust I am not wearying the Conference by dwelling on these historic details ; attention to them is absolutely necessary to the right understanding of our position, to the determination of the course we should pursue.

"I have now to ask the attention of the Conference to the change which was made in the position of the Irish Parliament by that which has been somewhat inaccurately called the Constitution of $\mathbf{1 7 8 2}$. In the proper sense of the word there was no new Constitution established in that year. Grattan and the Volunteers compelled England to renounce the claim of legislating for Ireland, and it was solemnly declared that no power on earth could make laws to bind Ireland except the King, Lords, and Commons of Ireland. It is impossible to exaggerate the importance and the value of that great achievement. It placed the liberties of Ireland in the keeping of her own Parliament; it removed the galling sense of subjection and dependence; while its immediate practical importance was chiefly felt in freeing the trade and commerce of Ireland from restrictions which the claim of the right to legislate for Ireland had enabled the English Parliament, under one pretence or other, to impose. The commercial as well as the civil freedom of the country was placed under the guardianship of the Irish Parliament 
itself. The truth is, that in the purely internal affairs of Ireland the instances of direct and actual interference by English legislation had been but few and comparatively unimportant.

"The only change which was then made in the Parliamentary constitution of Ireland was by a modification in the Law of Poynings. The Irish Parliament was authorised to consider and to pass Bills without the previous sanction of the English Privy Council. But that assent-the approval of the English Privy Council -was still made necessary to their becoming law. In all other respects the Parliamentary system of Ireland was left untouched. The absolute dependence of the Crown of Ireland upon that of England was absolutely reaffirmed. The House of Commons was elected exactly in the same manner as before, and its legal and constitutional powers were unchanged.

"It is strange, Sir, how little the real constitutional history of this period is understood. There are many persons I know who have been under the impression that in 1782 all control over Irish legislation in the English Privy Council was removed. Far from it; the consent of the Sovereign under the Great Seal of England was still necessary before any measure could become law. This arrangement was expressly made part of the Declaration of Rights moved by Mr. Grattan in the Irish House of Commons. On the 16th April, 1782, Mr. Grattan moved the Address to the King which denied the power of the English Parliament to make laws for Ireland. But, after solemnly making that denial, and after affirming the inseparable annexation of the Crown of Ireland to that of Great Britain, on which connection, 
in the words of the address, " the interests and happiness of both nations essentially depend,' that address proceeded-

'To assure his Majesty that his Majesty's Commons of Ireland do most sincerely wish that all Bills which become law in Ireland should receive the approbation of his Majesty under the Great Seal of Britain, but that yet we consider the practice of suppressing our Bills in the Councils of Ireland, or altering the same anywhere, to be a just cause of jealousy and discontent.'

"These are the words of the celebrated Declaration of Rights - the claim of the legislative independence of Ireland-solemnly put forward by Mr. Grattan and the Irish Parliament of 1782 . In reply to this address, the Duke of Portland, on the 27th May, conveyed to both Houses of the Irish Parliament a message from the King, telling them that in addition to the renunciation by the British Parliament of the claim to bind Ireland-

'The concessions so graciously offered by our Sovereign are the modification of Poynings' Law, and not only the abridgment of the Mutiny Bill in point of duration, but the formation of it on the model of the English Mutiny Bill, and prefacing it with a Declaration of Rights.'

"Nothing can be more distinct than the deliberate intentions of the men who led the Irish Nation in 1782 to retain a portion of the subjection to the English Privy Council in which the Law of Poynings placed the Parliament of Ireland. The restrictions of that law had been imposed by an Act of the Irish Parliament. An Act of the Irish Parliament could remove them. Accordingly, a Bill was brought in by Mr. Yelverton, modifying the Law of Poynings. Mr. Flood alone objected to that Bill as falling short of that which Ireland had a right to demand. The measure of Mr. Yeiverton provided that the Bills which passed both Houses of the Irish Parliament should be certified by the Lord Lieu- 
xxii.

tenant under the Great Seal of Ireland to his Majesty, and should not pass until they were returned under the Great Seal of Britain. It also provided that they should be returned without alteration, but it left untouched the requirement of Poynings' Law that Irish Bills must be sent over to England and returned with an approbation certified under the Great Seal of that country-that it is approved of by the advice of English Ministers and the English Privy Council. This provision was wholly distinct from the constitutional necessity of obtaining the royal assent. That assent was subsequently given by the Lord Lieutenant in the name of his Majesty in the Irish House of Lords. The certifying of the Bill under the Great Seal of England was a condition precedent to the King of Ireland giving his assent. Mr. Grattan pointed this out very clearly in the Regency debates. Lord Clare illustrated it very strongly, but not more strongly than truly, by the statement, that if his Majesty came to Ireland, appointing a Regent for England in his absence, the King could not have given the royal assent to any Bill in his Irish Parliament until his Regent had certified it to him under the English Great Seal. The provision virtually gave to the English Privy Council the power of negativing any Irish measure of legislation; and it would be easy to show how strongly this veto was relied upon by the National Party in the Irish Parliament as a real and practical security for the connection between the countries.

"The real concession which was obtained on this point-and it was a most important one-was that measures might be passed in both Houses of the Irish Parliament without the previous assent of the English Privy Council. That assent was now required, not 
before their introduction, but after they had passed. The restriction was no longer on the deliberative, but solely on the legislative power of the Irish Parliament. But let it be remembered that from 1782 to 1800 there did exist that restriction on its legislative power which consisted in requiring an assent under the Great Seal of England before any measure passed by it could become law.

"But under the arrangements which existed during the same period there was no such thing as an Irish administration responsible to the Irish Parliament. In modern times it is considered essential that the Ministers of the Crown should possess the confidence of Parliament, and that when they cease to do so they should resign. This is now established as the constitutional practice in Canada and in the Australian colonies. You will find it remarkably established in papers recently laid before Parliament, connected with the retirement from office, in the colony of Victoria, of the ministry of Sir Charles Duffy. But no such practice had ever been established in Ireland. If it had been, Irish liberty could never have been destroyed. In 1799, when Lord Castlereagh first introduced the measure of the Union, it was defeated. Had the constitutional practice prevailed he must have resigned, and a Minister opposed to the Union must have taken his place; but in Ireland the Ministers were the mere creatures of the English administration, changing when that administration changed, and therefore really dependent for their continuance in office on the votes, not of the Irish, but of the English Parliament. I have marked some extracts from the books before me, intended to show the importance of this subject. But that importance is so manifest, and I have so many matters to go 


\section{xxiv.}

over, that I am unwilling to dwell upon this. I will only ask you to remember that before the Union there was no such thing as an Irish administration responsible to an Irish Parliament, even for the management of purely Irish affairs.

"But while Ireland, even after 1782 , was thus left without any real responsible administration of her internal affairs, in all that concerned her external relations she was absolutely subject to the action of the English Sovereign, taken under the advice of English Ministers, controlled by an English Parliament, in which Ireland had no voice. It was the King of England who entered into treaties with foreign nations by the advice of his English Privy Council. It was the King of England who, by the same advice, declared war or made peace. By those treaties Ireland was bound. A declaration of war involved Ireland in that war. A treaty of peace bound Ireland by its terms: In all these things Ireland was the subject country, just as much bound by the Acts of the English Government as Canada or Australia are now bound. When George III., by the advice of his English Ministers, declared war against France, the King of Ireland was at war with that country, and every Irishman who aided or held intercourse with his French enemies was guilty of high treason. This is not matter of theory. "It was the actual and literal state of fact. The army was the army of England; the navy was the navy of England ; the ambassadiors to all foreign courts were the ambassadors of the King of England. All the colonies were dependencies of the English Crown; and over their government Ireland or the Irish Parliament did not exercise the slightest control. 
"I have asked your attention to the real position of the Irish Parliament even after the concessions of 1782 . Let me carry you back for a moment to the period of the Revolution, and ask you to observe what was accomplished by that Parliament in the century which followed. If I desired to point to an illustration of the value and power of the most enfeebled Parliamentary institution, I could not find one more striking than that which is supplied in the history of the Irish Parliament. It was not the Parliament of the whole people-it was chosen exclusively by the representatives of the Protestant minority, while the Catholic majority were excluded from all share of political power. It was not chosen by the voice even of the Protestant people. Nearly two-thirds of its Members were sent in by a system of nomination from which all popular influence was excluded. It had no Irish administration through which it could bring its influence to bear directly on the counsels of the Sovereign-Irish Ministers were the irresponsible agents of English parties. It was hampered in all its movements by the law, which, in its strict interpretation, forbade even the consideration of measures which had not been previously sanctioned by an English Privy Council-without any real possession of the powers, even in financial matters, which enabled the English House of Commons to assert the rights of the English people. It is impossible to conceive a more disadvantageous position than that in which the Irish Parliament was placed. Yet see what it accomplished. In the beginning of the last century its Members were elected virtually for life ; they could not be disturbed except by the death of the sovereign or a dissolution. They extorted from the English Privy Council a reluctant assent 
to a measure which shortened the duration of Parliament to eight years. I am not sure that the Members of the present House of Commons, if we felt ourselves virtually secure of our seats for life, would make a similar sacrifice to public liberty. We can scarcely avoid noticing the contrast between the legislatures of the two countries. In England, a House of Commons elected for three years passed a statute extending its tenure to seven. In Ireland, a House of Commons elected for the life or during the pleasure of the Sovereign abridged its tenure to seven years-it was in the English Privy Council that the term was altered to eight years, in the hope that the Irish Parliament would reject the Bill, when so altered, as a violation of their privileges. It was the same Parliament which established the Volunteers. It wrung from England the solemn renunciation of her usurped claim of legislating for Ireland-it modified the Law of Poynings-it established, after years of conflict, the necessity of an annual Mutiny Bill to be passed by the Irish Parliament-it asserted for itself the right of originating and appropriating supplies. When its existence was put an end to by violence and corruption and fraud, it was gradually establishing the same constitutional privileges of Parliament which have been the safeguards of English freedom. But more than this. A Protestant Parliament, elected exclusively by Protestants -it had repealed the Penal Laws which ground down the Catholic people. In 1793 it admitted the mass of the people to share political power with their Protestant countrymen. In that year it gave Catholics the elective franchise, long before the exclusion was removed in England; and in the same year the degrees in the University of Dublin were opened to Roman Catholics, 
a measure of liberality which the English universities have imitated within the last few years. It was the same Protestant Parliament that established and endowed a Catholic seminary for Catholic priests. It is hard for us now, in the advance of liberal opinions, to realise all that was involved in these measures. But when we remember that a Parliament representing a portion of the people who enjoyed a monopoly of political power, of the learned professions, and of the landed property of the country, had gone thus far in admitting their Catholic countrymen to a share in all these, we may well believe, with Mr. O'Connell, that if that Parliament had not been extinguished, a very few years would have seen the removal of every religious disability, and the admission of the Catholic people to a full participation in all the privileges of the Constitution.

" These triumphs of the principles of civil and religious liberty were achieved in a Parliament hampered and enfeebled by defects and difficulties such as I have described. Need I remind you of what it did for the material prosperity of the country in the eighteen years during which the renunciation of all claims on the part of England to legislate against Irish commerce left us free to foster the industry and enterprise of Ireland. 'There is not,' said Lord Clare, speaking in 1798 , 'a nation on the face of the habitable globe which has advanced in cultivation, in agriculture, and in manufactures with the same rapidity as Ireland.' I will not weary you by quoting testimonies with which many of us are familiar. Our sea fisheries, now decaying and perishing, before the Union had driven the Scotch and English trade out of the Continental markets. They were a source of wealth to the country and employment 
to our population. Everywhere our manufactures flourished, in streets, in villages, in districts where all manufacturing industry is now extinct. All testimonies bear out the statements of Lord Grey in the English House of Lords, of Mr. Foster and Mr. Plunket in the Irish House of Commons, that, in the words of Plunket, 'Ireland's revenue, her trade, her manufactures had thriven beyond the hope or the example of every other country of her extent within the few years before the Union with a rapidity astonishing even to herself.'

"But there are in the Irish heart other and higher memories associated with that Parliament. Every Irishman is proud of its glory and its fame. No one will say that he is not justly so. In the proudest and noblest days of English Parliamentary history, in the days of Pitt, of Fox, and of Erskine, when Ireland, indeed, contributed to the splendour of the English senate the grand additions of her Sheridan and her Burke, our Irish Parliament suffered nothing by a comparison with the great-it was a great-assembly at Westminster. Never, perhaps, was there an assembly which produced so many men destined to be great within the same period as that Irish Parliament. The name of Arthur Wellesley, or, as he then called himself, Wesley, was upon its rolls. Among its prominent Members was Castlereagh, afterwards the director of the foreign policy of England, and thus to some extent the arbiter of the destinies of Europe. Fitzgibbon, although, like Castlereagh, the enemy of his country, was in intellect equal to the greatest of his rivals. The walls of our Senate House echoed to the voices of Bushe and of Plunket. The fame of our own Parliament, the memories of Grattan, of 
Curran, and of Flood, are some of the precious inheritances with which a nation may not part, and wherever in any other country or in any clime there is an Irishman who has a pride in the glories of his country, his heart turns in passionate remembrance to that Senate House which threw a lustre on our land--the Senate House which he fondly remembers as "the Old House in College Green.'

"I resume my narrative, and come to the passing of the Act of Union. I have shown you what the Irish Parliament had done-how it had asserted civil and vindicated religious liberty-how it had promoted the material prosperity of the country-how its genius and intellect had thrown lustre on the national annals. We must give a few minutes' attention to the means by which it was destroyed.

"Let me read for you the words in which Lord Plunket, then Mr. Plunket, resisting the Union in the Irish House of Commons, described those means. $\mathrm{He}$ spoke at a time when the atrocities of the French revolution were not, as they are with us, the transactions of the far-off past, but when they were visibly present to the minds of the generation in which they were enacted. It was at such a time that he said :-

- I am bold to say that licentious and impious France, in all the unrestrained excesses to which anarchy and atheism have given birth, has not committed a more insidious act against her enemy than is now attempted by the professed champion of the cause of civilised Europe against a friend and ally in the hour of her calamity and distress - at a moment when our country is filled with British troops, when the loyal men of Ireland are fatigued and exhausted by their efforts to subdue the rebellion-efforts in which they had succeeded before those troops arrived-whilst the Habeas Corpus Act is suspended-whilst trials by courtsmartial are carrying on in many parts of the kingdom - whilst the people are taught to think they have no right to meet or deliberate ; and whilst the great body of them are so palsied by their fears 
and worn down by their exertions, that even this vital question is scarcely able to rouse them from their lethargy-at a moment when we are distracted by domestic dissensions-dissensions artfully kept alive as the pretext of our present subjugation and the instrument of our future thraliom.'

" ' The country,' said Mr. Plunket, ' is filled with British troops.' Before the English Government ventured to propose the Union, they passed an Act giving a bounty of $f_{1} 0$ to every Irish militiaman who would enlist for foreign service. This appeared to be an Act influenced only by the desire to invite Irish valour to the defence of the empire in its foreign wars; but mark what followed. Ten regiments of Irish militia accepted the bounty and volunteered for foreign service. They were instantly replaced by ten English regiments ; so that it was manifest that it was not for the purpose of taking troops abroad that this was done. While England was engaged in a desperate Continental struggle Ireland was held by 130,000 armed men-troops that had free quarters on the people, and on whose use of that privilege I do not choose to dwell. Let it be told in the burning words of their commander-in-chief.

"I have read to you the testimony of Mr. Plunket. I will cite one more. It is an extract from the protest in the House of Peers against the passing of the Act of Union-a protest signed by two Bishops and eighteen lay peers. The signature of the Duke of Leinster was the first. Twenty Members of the Irish House of Lords have left on record, in its journals, the protest in which, among other reasons, they objected to the act of Union in these words :-

- Because when we consider the weakness of this kingdom at the time that the measure was brought forward, and her inability to withstand the destructive designs of the minister, and couple with the Act itself the means that have been employed to accomplish it-such as the abuse of the Place Bill-for the 
purpose of corrupting the Parliament: the appointment of sheriffs to prevent county meetings; the dismissal of the old steadfast friends of the constitutional Government, for their adherence to the Constitution, and the return of persons into Parliament who had neither connexion nor stake in this country, and were thcrefore selected to decide upon her fate-when we consider the armed force of the minister. added to his power and practices of corruption-when we couple these things together, we are warranted to say that the basest means have been used to accomplish this great innovation, and that the measure of the Union tends to dishonour the ancient pecrage for ever, to disqualify both Houses of Parliament, and subjugate the people of Ireland for ever. Such circumstances, we apprehend, will be recollected with abhorrence, and will create jealousy between the two Nations, in place of that harmony which for so many centuries has been the cement of their union.'

"With these testimonies-with the testimony of all history-I may assume that the Union was carried by a system of force, and fraud, and corruption, for which no parallel is to be found in the history of a nation which was even nominally free." 



\section{The}

\section{Constitutional and Parliamentary}

\section{History of Ireland till the Union.}

I.

THE IRISH PARLIAMENT AND THE CLAIM OF THE BRITISH PARLIAMENT TO LEGISLATE FOR IRELAND.

ONE of the great representative facts which must always be borne carefully in mind in an attempt to obtain a knowledge of the true inwardness of Irish Parliamentary history has been admirably enunciated by Mr. Butt. "From the very earliest introduction," he writes, "of the power of the English Kings into Ireland, the Irish who submitted to the rule of these kings had the same Parliamentary constitution as that which England enjoyed." To this may be added as a corollary the statement that, wherever English rule prevailed, the English Constitution became the birthright of the Anglo-Irish colonists. " Ireland," said O'Connell, " had a Parliament as old as England. It rose as spontaneously from the congregation of freemen until the 
representation was much increased in the reign of James I. It had so existed, not as a favour, but as the inherent right of freedom, without which freedom was but a name."* In the parts of Ireland which Henry II. reckoned as his own, it was his aim to establish the English laws to render the lesser island, as it were, a mirror in all its civil constitutions of the greater. "The Colony from England was already not inconsiderable, and likely to increase; the Ostmen who inhabited the maritime towns came very willingly, as all settlers of Teutonic origin have done, into the English customs and language, and, upon this basis, leaving the accession of the aboriginal people to future contingencies, he raised the edifice of the Irish Constitution. $\mathrm{He}$ gave charters of privilege to the chief towns, began a division into counties, appointed sheriffs and judges of assize to administer justice, erected Supreme Courts in Dublin, and, perhaps, assembled Parliaments. His successors pursued the same course of policy; the great Charter of Liberties, as soon as granted by John at Runnymede, was sent over to Ireland, and the whole common law, with all its forms of process and every privilege it was deemed to convey, was established" (see Hallam, III., p. 350). The regular Constitution of Ireland was as nearly as possible the counterpart of the English Constitution. The administration was invested in an English Justiciary or Lord Deputy, assisted by a Council of judges and principal officers, mixed with some prelates and barons, but subordinate to that of England, wherein sat the immediate advisers of the sovereign. 'The Courts of Chancery, King's Bench, Common Pleas, and Exchequer were the same in both

* Debate on the Repeal of the Union in the Dublin Corporation, 184.3 . 
countries, but Writs of Error lay from judgments given in the second of them to the same Court in England. For all momentous purposes, as to grant a subsidy or enact a statute, it was as necessary to summon a Parliament in the one island as in the other. "An Irish Parliament, originally like an English one, was but a more numerous Council to which the more distant as well as the neighbouring barons were summoned, whose consent, though dispensed with in ordinary acts of state, was both the pledge and the condition of their obedience to legislative provisions " (Hallam, III., p. 355). Irish Parliamentary assemblies, such as they were, constituted under the English Kings, were simply imitations of English precedents. "It is not clear whether the introduction and confirmation of English law in Ireland was with the sanction of Councils in Ireland, or merely founded upon the royal authority." "Under John and Henry III., Councils enacted that the English laws and customs should be in torce in Ireland " (Ball's Irish Legislative Systems, p. 4). The question whether the power of the English Kings was established by right of conquest, as English writers have chosen to assert, or, as Irish writers have said, by the voluntary submission of some Irish Chiefs, which would now be regarded as of an interest purely academic, was in times past a subject of the fiercest controversy in connection with the assertion of authority by the English Parliament to make laws binding on Ireland. It was laid down, according to the judgment in Calvin's case, which was the composition of Lord Coke, and, although not the subject for the decision of the Court, had, despite its being a mere obiter dictum, a profound importance owing to the authority by whom it was delivered, that, " albeit 
Ireland was a distirct dominion, yet the title thereof being by conquest, Ireland might by express words be bound by the Acts of the Parliament of England."* The early Councils of nobles and prelates and other magnates summoned to advise the King, and to grant a subsidy, have been dignified by the name of Parliaments, but to these assemblies the name of Parliaments, as we understand the term, did not in reality apply, inasmuch as that form of legislative council to which we give the name of Parliament did not for several generations develop itself. Sir John Davies, the Speaker of the Irish House of Commons in $\mathrm{I}^{6} \mathrm{1} 3$, in the Parliament of James I., in his address to the Lord Deputy, Sir Arthur Chichester, gives a concise account of the previous Parliaments of Ireland. He was eminent in law and in literature, and, at the time of his death in 1626 , had just been appointed Lord Chief Justice of England. "And as there is now," he says, " but one common law, so for the space of 140 years after Henry II. had taken possession of the Lordship of Ireland, there was but one Parliament for both kingdoms. But the laws made in the Parliaments of England were, from time to time, transmitted hither under the Great Seal of that kingdom, to be proclaimed, enrolled, and executed as laws of this nation." This view is supported by Lord Coke in his chapter on Ireland in the Fourth Institute, where he states: "Sometimes the King of England called his nobles of Ireland to come to the Parliament of England, and, by special words, the Parliament of England may bind the subjects of Ireland." He then sets out the entry on the Parliamentary Roll, reciting the Writ by which the Irish nobles were summoned to Westminster to a Council, not to a Parliament in our

* Ball's Irish Legislative Systems, p. 23 ; Coke's Reports, " Calvin's Case," Part VII. 
sense of the term. Even after the establishment of Parliamentary institutions in Ireland, there is an instance of Irisin representatives being summoned to England in 1376 by Edward III., who, on his failure to obtain money from Ireland, had recourse to a Parliament at Westminster, attended by representatives from Ireland, not, however, without protests (Ball's Irish Legislative Systems, p. 19; $i_{i l d .,}$ pp. 224-225). In the reigns of Henry IV., Henry V., and Henry VI., the English and the Irish Parliaments advanced conflicting claims respecting their jurisdiction in Ireland. The former passed Acts expressly naming Ireland, and designed to bind its inhabitants. The latter, on the other hand, declared that Statutes made in England should not be of force in Ireland unless they were allowed and published in that Kingdom by Parliament. In the twentieth year of Henry VI., however, the English Judges in Pilkington's case had discussed the power of the English Parliament to tax Ireland, and had resolved against it.* But, in the reign of Richard III., eventually in the Merchants of Waterford's case, the English Judges decided that Statutes made in England did bind the people of Ireland. When, in 1459, Richard, Duke of York, appeared again in Ireland, where he had been previously Lord Lieutenant, and resumed his former office, several Statutes were passed, all tending to assert the legislative independence of Ireland. To these conflicting decisions, to the conflict of jurisdictions between the two Parliaments, probably to the fears entertained that, in a period of insurrection in England, an ambitious and unscrupulous Irish Lord Deputy might, for his own purposes, take advantage of troublous times to establish his own Sovereignty,

* Ball's Legislative Systems, pp. I6-I7. 
in 1495 the second of the Statutes named from Sir Edward Poynings, the Lord Deputy in whose term of office they were passed, was placed on the Irish Statute Book, whereby " it is enacted that all Statutes late made within the realm of England, concerning or belonging to the common or public weal of the same, from henceforth be deemed good and effectual in the law, and over that be accepted, used, and executed within the land of Ireland on all points at all times requisite, according to the tenor of the same. And if any Statute or Statutes have been made within the same land heretofore to the contrary, that they and every one of them be made void and of none effect in the law." Some question might be made whether the word "late" was not intended to limit this acceptation of English law, but, in effect, by this comprehensive and summary enactment, all the general fundamental laws previously in existence in England were transferred, without argument or opposition, exactly as they stood, into Ireland. This Act of Poynings referred only to English Statutes then existing; it had no effect upon future legislation. "The question of the jurisdiction of the English Parliament to make laws for Ireland remained in the same position as it was before."* It was probably considered that the Statute peculiarly known as Poynings' Law, which will be dealt with hereafter, would prevail sufficiently to effect the complete subjugation of the Irish to the English Parliament. The question, however, of the paramount authority of the English Parliament over the Irish Parliament was not yet settled. One of the articles of Strafford's impeachment, in which delegates from the Irish House of Commons were sent

* Ball's Legislative Systems, p. 22. 
over to offer assistance to the Lawyers, was " that the realm of Ireland, having been time out of mind annexed to the Imperial Crown of England, and governed by the same laws, the Earl (being Deputy in that Realm) to bring His Majesty's liege subjects into a dislike of His Majesty's Government, and intending the subversion of the fundamental laws and settled government of that Kingdom, and the destruction of His Majesty's liege people there, did declare and publish that Ireland is a conquered nation, and that the King might do with them what he pleased." Strafford, in reply, defended the proposition that "Ireland was a conquered country" as being true. Indeed, in 1640 , very soon after Strafford's recall from the Government of Ireland, the Irish House of Commons, imitating the precedent set by the English House of Commons, prepared a list of grievances, and, in order to ascertain whether these practices, which they asserted to prevail, were in accordance with the Constitution, drew up twenty-one queries, which were presented to the House of Lords, with a request that they should be submitted to the Irish Judges for their consideration and formal reply. The Lords did as desired, and the Irish Judges, very reluctantly, in May, 1641 , sent in their cautious and elaborate replies. One of the queries so submitted was: "Whether the subjects of this Kingdom (Ireland) be a free people, and to be governed only by the common law of England and the Statutes in force in this Kingdom ?" The answer of the Judges was not relished. The Commons desired a Conference, and, in the end, the House thereon resolved to promulgate its own ideas on the questions that had been sent to the Judges, which it embodied in a series of resolutions, of which 
the following was one: "That the subjects of His Majesty's Kingdom of Ireland are a free people, and to be governed only according to the Common Law of England and Statutes made and established by Parliaments in Ireland, and according to the lawful customs of the same."*

The English Parliament, however, soon afterwards passed an Act-the Adventurers' Act-which professed to dispose of the lands of the disloyal in Ireland in favour of persons who would advance money for quelling the rebellion in consideration of the lands to be thus allotted to them. This Statute, which plainly infringed upon the resolution of the Irish House of Commons, affirming the exclusive jurisdiction of the Irish Parliament, was the subject of protest to the Commissioners of Charles I., on the ground of its being legislation by the English Parliament for Ireland-the Acts of the Irish Parliament being alone binding on the King's Irish subjects. A treatise defending the rights claimed by the Irish Parliament, attributed to the pen of Sir Richard Bolton, Lord Chancellor of Ireland from 1638 till 1650 , was brought under the notice of the House of Lords, and was sent by the Lords to the House of Commons for consideration. The attention of Parliament was, however, distracted from constitutional questions by civil war.

After the Restoration, in May, r66r, a Parliament was called by Charles II. in Ireland. The great business of the Parliament and the Government was to carry the National Measure called the Act of Settlement, and afterwards to maintain it by the Act of Explanation (I4 \& 15 Car. II., c. 2 ; I7 \& I8 Car. II., c. 2). These Statutes were passed by the Irish Parliament

* Ball's Legislative Systems, pp: 25-27. Whiteside's Irish Parliaments, p. 64 . 
without any concurrence or assistance from the Parliament of England. This difficult, painful, and laborious undertaking of conferring possessions and settling, as far as could be done, the land question in Ireland, was carried on by Sir Heneage Finch, afterwards Lord Nottingham, Lord Chancellor of England. It was hotly debated whether the settlement of Ireland should be transacted by the English or the Irish Parliaments. Finch seems in favour of the Irish Parliament, assigning as his reason that, if they did the business in England, the laws of the English Parliament would only be binding by sufferance, and vested by adoption in Ireland. The Irish Parliament placed on record its grateful sense of the labours of Sir Heneage Finch. The claim of the English Parliament to legislate for Ireland, although not asserted in the momentous work of the settlement of property in Ireland, was, nevertheless, not suffered to lie dormant. "That the English Parliament of Charles II.," writes Dr. Ball, " abstained from interfering with the redistribution of land, which, during his reign, was arranged in Ireland, did not arise by reason of its having relinquished the legislative claims of former English Parliaments; on the contrary, the claims were persisted in, and among other enactments of this period which related to Ireland the tobacco plant there was prohibited" (Ball's Legislative Systems, p. 33).

With the Acts of the English Parliament excluding Irish ships from the plantations and colonies of England, and Irish goods from England herself, we are not for the present concerned. These laws did not control Irish legislation, nor interfere therewith, and were, however harsh and iniquitous, well within the powers 
of the English Parliament. England had an unquestioned power over her own plantations, colonies, and ports.* In many cases, moreover, after the Revolution, the Irish Parliament acquiesced in legislation of the English Parliament affecting Ireland. In 1690 , by an English Statute, the Acts and proceedings of the Irish Parliament of King James II., I689-I690, were declared null and void (I Wm. \& M., c. 9, et seq.). In I695 an Irish Statute declared the Acts and proceedings of James' Irish Parliament null and void, and added that the records of them should be burnt ( 7 Wm., c. 3 , Irish). Until I69I Roman Catholics were admissible by law into both Houses of Legislature in Ireland. Their exclusion was effected by an English Statute of this year (3 Wm. \& M., c. 2, Eng.), by which the provisions of a former English Act (30 Car. 2, pp. 2, c. I) were declared to extend to Ireland. That the Irish Parliament acquiesced in this Statute is partly evident from an Irish Statute of 1697 (9 Wm. III., c. 3, sec. 2), whereby a Protestant marrying a Catholic was disabled from sitting or voting in either House of Parliament. This Act would have placed the Protestant so married to a Catholic in a worse position than that of a Catholic Peer or Commoner, if he had not been deemed already excluded by the English Statute (Scully's Irish Penal Laws, pp. 65-66). The Act for the resumption of the enormous grants of land bestowed out of forfeited estates in Ireland by William III. on his mistress, Elizabeth Villiers, and other persons of like merits and character, was an English Act (II \& I2 Wm. III., c. 2), and an instance-perhaps the most remarkable of all-the measures hindering the export of wool from Ireland, which caused the production of Molyneux'

* Ball, pp. 33-34. 
celebrated treatise, entitled, The case of Ireland, being bound by Acts of Parliament in England stated, in 1698, were due, not merely to English legislation, but to the legislation of the enfeebled Irish Parliament, passed that year, which, in the words of Froude, "was invited to put the knife to its own throat," under circumstances which will be stated.*

Although the Irish Parliament made no protest against the legislation of the British Parliament affecting to bind Ireland, and even to cripple her trade with countries other than England, there was, no doubt, a feeling of the very deepest indignation in Ireland in reference to this policy, which would have found its expression in the legislature itself, if that corrupt body were amenable to pressure from without. The treatise of Molyneux, which produced so profound an impression, was published in 1698 - the very year which witnessed the destruction of the Irish woollen trade by the enactments of the English and the Irish Parliaments. The high notions of Parliamentary sovereignty, which were of the essence of the Revolution, strengthened the pretensions of the English Parliament to legislate for Ireland. Mr. Hallam has well observed that, while sovereignty and the enacting powers were supposed to reside wholly in the King, and only the power of consent in the two Houses of Parliament, it was much less natural to suppose a control of the English legislature over other dominions of the Crown having their own representation for similar purposes than after they had become in effect and general sentiment, though not quite on the Statute Book, coordinate partakers of the supreme authority. $\dagger$ The

* Froude's English in Ireland, I., p. 297.

$\uparrow$ Hallam's Constitutional History, III., p. 406. 
English House of Commons passed resolutions against the treatise of Molyneux, directed that it should be burnt by the common hangman, and addressed the King in condemnation of its doctrines, denying the authority of the King and people of England to bind the kingdom and people of Ireland, and the subordination and dependence that Ireland has, and ought to have, upon England, as being united and annexed to the Imperial Crown of that realm. Legislation on the subject would, of course, be a still more decisive mode of asserting a right. At that time the English House of Lords was the ultimate appellate tribunal from the English Courts of Chancery and Common Law. It assumed the same jurisdiction over the Irish Courts. In I7I9 the case of Sherlock v. Annesley was tried in the Irish Court of Exchequer, in which Annesley obtained a decree against Sherlock, which, on appeal to the Irish House of Lords, was reversed. From this sentence Annesley appealed to the English House of Lords, who confirmed the judgment of the Irish Exchequer, and issued process to put him into possession of the litigated property. Sherlock petitioned the Irish Lords against the usurped authority of England, and they, having taken the opinion of the judges, resolved that they would support their honour, jurisdiction, and privileges, by giving relief to the petitioner. Sherlock was put in possession by the Sheriff of Kildare; an injunction issued from the Court of Exchequer, pursuant to the decree of the English Lords, directing him to restore Annesley. The Sheriff refused obedience. He was protected by the Irish Lords, who addressed the Throne, recapitulating the rights of Ireland, her independent Parliament and peculiar jurisdiction. The Irish House of Lords sent 
the Barons of the Irish Court of Exchequer to jail. The address of the Irish House of Lords to the King was laid before the English House of Lords. That House re-affirmed their proceedings, and supplicated the Throne to confer some mark of special favour on the Barons of the Exchequer. This contest produced the Act so well known as the sixth of Geo. I., c. 5, which was passed by the English Parliament, by which the entire dependence of the Irish on the English Parliament was thus declared: "Whereas attempts have lately been made to shake off the subjection of Ireland upon the Imperial Crown of this Realm, which will be of dangerous consequence to Great Britain and Ireland: And Whereas the Lords of Ireland in order thereto have of late against law assumed to themselves a power and jurisdiction to examine, correct, and amend the judgments and decrees of Courts of Justice in the Kingdom of Ireland, therefore for the better securing of the dependency of Ireland upon the Crown of Great Britain, may it please Your Majesty that it may be enacted, and it is hereby declared and enacted by the King's Most Excellent Majesty, by and with the advice and consent of the Lords Spiritual and Temporal and Commons in the present Parliament assembled, and by the authority of the same, that the said Kingdom of Ireland hath been and of right ought to be subordinate unto and dependent upon the Imperial Crown of Great Britain as being inseparably annexed and united thereunto, and that the King's Majesty, by and with the advice and consent of the Lords Spiritual and Temporal and the Commons of Great Britain in Parliament assembled, both hath had of right and ought to have full powers and authority to make laws and statutes of sufficient force and validity to bind 
the people and kingdom of Ireland. And be it further enacted and declared by the authority aforesaid that the House of Lords have not nor of right ought to have any jurisdiction to judge, affirm, or reverse any judgment, sentence, or decree given or made in any Court within the same Kingdom, and that all proceedings before the said House of Lords upon any such judgment, sentence, or decree are and are hereby declared to be utterly null and void to all intents and purposes whatever."* In Blackstone's Commentaries on the Laws of England, which was published in 1765 , and attained an extraordinary reputation, the right of the British Parliament to bind Ireland by its laws was maintained without any qualification or restriction.

* In the Introduction to MacNevin's History of the Volunteers there is a very succinct account of this incident. 
II.

\section{POYNINGS' LAW AS AFFECTING THE IRISH PARLIAMENT.}

Having dealt with the claim of the English Parliament to legislate for Ireland embodied in the Act of George I., to complete our view of the constitution of the Irish Parliament we must remember that by an Act of that Parliament itself a most important restriction was placed on its legislative powers. In 1495 the famous Act, emphatically called Poynings' Law, was passed, which regulated the mode of summoning Parliaments, and of passing laws. By this Statute it is enacted that no Parliament shall in future be holden in Ireland till the King's lieutenants shall certify to the King under the Great Seal the causes and considerations, and all such acts as it seems to them ought to be passed thereon, and such be affirmed by the King and his Council, and his licence to hold a Parliament be obtained. Any Parliament holden contrary to this form and provision should be deemed void. Thus, by securing the initiative power to the English Council, a bridle was placed in the mouth of every Irish Parliament. We can thus understand the reason that English Statutes were not in conflict with Irish since Poynings' Law gave the King and his Council in England control over the legislation of the Irish Parliament, which could not without licence and assent under the Great Seal of England either alter or make laws. "It is probable that Poynings' Law was 
designed as a check on the Lords Deputy, sometimes powerful Irish nobles, whom it was dangerous not to employ, but still were dangerous to trust" (Hallam's Constitutional History, III., p. 362). Mr. Flood, who stated that he had devoted close attention to the construction of this Statute for twenty years, contended that Poynings' Law, which had been framed for the purpose of controlling the power of the Lords Deputy, and reserving the prerogative of assent or dissent in Irish legislation to the King, was tortured into an engine for depriving the Irish Parliament of any initiative in legislation by the corrupt and vicious interpretation of its provisions by the Irish and the English judges, by opinions delivered by the Irish judges to Lord Sydney as Lord Lieutenant of Ireland in February, I692, and by the English judges of King William III. on June 22nd, I693. James I., according to Mr. Flood, kept the Irish Parliament from all initiative in legislation. When some effort at independent legislation was made by that Parliament, the King "sent over for a convention of the Members, whom he ordered to attend him in England, and, having lectured them on the divine authority of kings and the mysterious art of legislation, and having informed them that it was a subject above the capacity of Parliament, these gentlemen came home much better courtiers than they went, and consented to a resolution, soon after proposed, that Parliament was but the humble remembrancer to His Majesty." In his argument in support of the contention that Poynings' Law was never intended to take away the right of Parliament, but merely to prevent the governors of Ireland from giving assent to laws that might be injurious to the King, Mr. Flood said that 
during the civil wars of York and Lancaster this had frequently happened : that the adherents of the York family, very numerous in Ireland, having been planted there chiefly in the reign of Henry VI., also sent the Duke of York with great power and great revenue to govern the Kingdom for no less than ten years, during which time and afterwards it became an asylum to the partisans of that House; that Lord Gormanston, who had preceded Poynings, had given great cause of suspicion; nay, it was even thought that when Simnel was crowned in Dublin, if there had been a Parliament sitting, that Parliament would have acknowledged him as rightful King; that voyages between England and Ireland in those days were much less frequent than between Europe and America at present, consequently many things happened here that were not known till long after in England, for which reason Henry VII., who derived his right from the House of Lancaster when he chose that trusty servant Poynings to be his deputy here, though he had the utmost reliance in his fidelity, yet would not entrust even him with the power of giving the royal assent to laws till they had been notified to the King himself in England under the sanction of the Great Seal of Ireland ; but that this was considered only as a restraint on the Governor, not on the Parliament of Ireland, which he proved had constantly pursued the practice of originating such Bills as they thought proper, and sending them engrossed on parchment, sometimes through the Lord Deputy, sometimes through special messengers of their own, to receive the royal assent. He said that Lord Bacon, who wrote the history of the reign of Henry VII., and who particularly mentions Poynings, would not have let so great 
a matter as the total perversion of our Constitution pass by the accuracy of his penetrating genius. He mentions the law of Poynings, indeed, but not this law. -Speaking of Poynings, he says: "But in Parliament he did endeavour to make awards for the meagreness of his services in the war, for there was made that memorable Act called Poynings' Act, not the Act that we are debating on, but that 'whereby all the Statutes of England were made to be of force in Ireland,' for before (says Lord Bacon) they were not" (Irish Debatcs, I., pp. 149-153).

The original law required the assent of the English Privy Council to be given to the intended Bill before Parliament met. In the reign of Queen Mary it was modified, so as to admit of that assent being given while Parliament was sitting, but that assent was still necessary to authorise the introduction of the Bill, although by contrivances of extraordinary ingenuity. legislative proposals had been brought into both Houses of the Irish Parliament at different times; sometimes they were called petitions, and sometimes heads of Bills.* With these modifications, which we will describe, the Law of Poynings continued in force till 1782 . A Bill, introduced into the Irish Parliament after it had been manipulated first by the Irish and then by the English Privy Council, could not be altered by the Irish Parliament, by whom it could only be passed in the exact words in which it was framed, or absolutely rejected. The workings of Poynings' Act and the Explanation Act of Philip and Mary in the Irish legislative system was thus described in the Irish House of Commons by Sir Frederick Flood: "Every man must acknowledge that before the tenth of Henry VII. and the third and fourth of Philip and Mary, our Parliamentary Consti-

* 3 and 4 Philip and Mrary (Ireland), c. 4. 
tution and the mode of passing Bills and making laws were the same as it is in England this day. Every man will acknowledge that the ancient Parliamentary Constitution of Ireland knows no persons but the King, Lords, and delegates of the people. Every man will acknowledge that the Privy Council is a body of men not even known to our ancient Constitution, in whom the Constitution placed no confidence, and yet they assume a power under misconstrued Acts of Parliament of throwing themselves between the Parliament of Ireland and their Sovereign. They delay, they stop and stifle, they mutilate, castrate, and misrepresent the acts of both Houses. All we desire is to be suffered to lay our petitions before the Royal Courts in our own words, and to remove that pale or barrier which obstructs the free communication between His Majesty and his subjects of Ireland, as it must be admitted on all hands that before the tenth of Henry VII. and the third and fourth of Philip and Mary we enjoyed the English Constitution here" (Irish Parliamentary Debates, I., p. I60).

On April 16th, 1782, Mr. Grattan thus described in the Irish House of Commons the effects of Poynings' Law on Irish Parliamentary measures: "As to the legislative powers of the Privy Councils, I conceive them to be utterly inadmissible against the Constitution, against the privileges of Parliament, and the dignity of Parliament. Do not imagine such power to be theoretical; it is in a very high degree a practical evil. I have here an inventory of Bills altered or injured by the interference of the Privy Council, Money Bills originated by them, protests by the Crown in support of these Money Bills, prorogations following these protests. I have here a Mutiny Bill of 1780 , altered by 
the Council, and made perpetual; - a Catholic Bill in $\mathrm{I}_{77} 8$, when the Council struck out the clause repealing the Test Act; a Militia Bill, when the Council struck out the Compulsory Clause requiring the Crown to proceed to form a militia, and left it optional to His Majesty's Minister whether there should be a militia in Ireland. I have the Money Bill of 1775 , when the Council struck out the Clause enabling His Majesty to take part of our troops for general service, and left it to the Minister to withdraw the forces against Act of Parliament. I have to state the altered Money Bill of 1771 , the altered Money Bill of 1775 , the altered Money Bill of $\mathrm{x} 780$-the day would expire before I could recount their ill-doings. I will never consent to have men (God knows whom)-ecclesiastics, etc., etc.-men unknown to the Constitution of Parliament, and only known to the Minister who has breathed into their nostrils an unconstitutional existence, steal to their dark divan, to do mischief, and make nonsense of Bills which their Lordships, the House of Lords, and we, the House of Commons, have thought good and fit for the people. No, these men have no legislative qualifications ; they shall have no legislative powers."

On the 17 th May, 1782 , Mr. Fox, speaking in the English House of Commons, as Secretary of 'State, thus explained the influence of Poynings' Law on Irish legislation, and its effect on votes in the Irish Pariiament, which he described with plainness of speech : "It must be admitted," he said, "that by this law a strange alteration has been made in the form of the Constitution of Ireland by making the Privy Council of that kingdom a branch of the legislature, and those who were acquainted with the nature of the interference of 
that Privy Council know very well that it was of the greatest detriment to the State, for not only it sometimes suppressed Bills which had passed the House of Lords or Commons nemine dissentiente, but such was the nature of it that Bills were sometimes passed according to the form indeed, but, in fact, nemine dissentiente, when it was contrary to the intention of any man in the House that such Bills should pass; they were, nevertheless, supported by all in confidence that in the Privy Council they would be thrown out. This kind of conduct was purely to gain popularity ; so that men who did not wish to oppose popular opinions which they did not approve should nevertheless unanimously give way to these opinions merely because they knew they would be rejected in the Privy Council.* For his own part, he was free to confess that the interference of that body, and their power to stop Bills in their progress from Parliament to the King, appeared to him improper, and therefore he could have no objection to advise His Majesty to the modification which they required of that law, from which the Privy Council derived that power. But the jealousies of the Irish went farther; they were jealous of the interference of the English Privy Council, and he admitted that the alterations which had sometimes been made by it in Irish Bills had given but too just cause for jealousy. It was generally understood in Ireland that Irish Bills were frequently altered in England, with very little consideration, and sometimes by a single person-the Attorney-General-which single person, the Irish imagined, made alterations without giving that attention to the Bills which the importanceof the subjects required. He would not say that these opinions were, in general, well founded, but this he was

* Appendix I. 
convinced of, that this power of altering might have still remained if an improper use had not been made of it ; but, to his knowledge, it had been grossly abused-in one instance, in particular, a Bill had been sent over to England two years ago, granting, and very wisely and very justly granting, indulgences to the Roman Catholics ; in that same Bill there was a clause in favour of the Dissenters for repealing the Sacramental Test. This clause was struck out, contrary, in his opinion, to sound policy, as the alteration tended to make an improper discrimination between two descriptions of men, which did not tend to the union of the people. It was by such conduct that the Irish were driven to pronounce the interference of the English Privy Council in altering their Bills a grievance, though, in his opinion, the power would never have been complained of if it had never been abused."*

Lord Mountmorres, writing in 1792, with a Parliamentary experience of the working of Poynings' Law, both before and after its modification, gives an account of this Statute as a factor in Irish legislation of which the following is a summary: Till 1495 laws were passed, and the Lords Lieutenant gave the Royal Assent from their own power and authority, as the King did in England; but, a bad use having been made of this power in the disputes between York and Lancasterparticularly by Richard, Duke of York-it was enacted by Poynings' Law that no Parliament should be held in Ireland till the Chief Governor and Council should certify to the King the causes and considerations for holding the same, or, in other words, all the Acts which were intended to be passed in the ensuing Parliament. This law appears to have been rigidly enforced in the 
subsequent Parliaments of Henry VII. and in the earlier Parliaments of Henry VIII., but, in the twenty-eighth and thirty-third years of that monarch's reign, two Parliaments were held which were licensed, notwithstanding the prescriptions of Poynings' Law had not been observed, by two laws which repealed Poynings' Act, and the last of them declares any person guilty of felony who should dispute the validity of that Parliament, notwithstanding it had been held contrary to the tenor of that Law. Probably the impossibility of foreseeing all the provisions which the exigencies of the State might render necessary to be passed into laws, rendered these temporary repeals unavoidable. Thus the Statute of $\mathrm{I} 54 \mathrm{I}$, raising Ireland from a Lordship into a Kingdom, was passed by a Parliament during the temporary suspension of Poynings' Law. In the third ard fourth of Philip and Mary an Act was passeci for the explanation of Poynings' Law, by which permission was given to the Lord Lieutenant and Council, while Parliament was sitting, to certify to the King such provisions as they might deem expedient to be formed into laws during a session of Parliament-a regulation which, naturally, arose from the fluctuating state of the times. In the second session of the eleventh of Elizabeth an Act was passed for suspending the provisions of Poynings' Law in consequence of unforeseen difficulties which had arisen in the collection of the revenue. Lord Mountmorres considers this Act, which was opposed by a considerable section in the House of Commons, from which the "Country Party" was to spring, to have been unnecessary, as provision had been made for such laws as were necessary to be made while Parliament was sitting by the Statute of Philip and Mary. 
Lord Mountmorres, however, has overlooked the fact that a very considerable time must have elapsed between the transmission of a Bill to England to be certified under the Great Seal and its return to Ireland for introduction in one of the Houses of the Irish Parliament. From a subsequent law of another session in the same year ( 1569 ), it appears that this Act was probably carried in a thin House, and by surprise, for it was thereby enacted that any proposition for suspending Poynings' Law should be agreed upon by the greater number of the Lords and Commons, which, taken in a literal sense, appears very extraordinary, as that is the case of every proposition and of every law which passes in Parliament. But the true meaning of this law probably was that the major part of the Lords and Commons who were summoned to Parliament, not those who were present on a given day, should consent to such a proposition. This regulation, Lord Miountmorres naïvely remarks, was strictly complied with in 1782 , as the present (1792) happy alteration in the mode of holding Parliaments and of passing laws was passed unanimously.

Various were the disputes and infinite were the jealousies which were engendered by this pernicious law till the last happy period in the Irish Parliament. It was usual, at the beginning of every new Parliament, for the Council to send to England a short Money Bill, which the House of Commons constantly rejected. This was the cause of a dissolution of Parliament in 1692 , and of a prorogation in 1769 . On both these occasions the Lords Lieutenant, Lords Sydney and Townshend, entered protests upon the Lords' Journals against the votes of the House of Commons, measures which were insolent, impolitic, and contrary to the usages of Parliament. 
This law was regarded by some as a sacred palladium of the English Government, which it was almost sacrilegious to touch, and to propose its repeal was considered as a political profanation. Even doubts seem to have been entertained of the propriety of such a proposition by the following entry on the 2nd December, 1757, in the Commons' Journal: "Resolved-That it is the undoubted right of every Member to declare his opinion touching the construction of Poynings' Law, and to move for its repeal without incurring any pains or penalties for the same, and any threat to deter a Member from so doing is a breach of the privilege of this House."

This truism, for such it certainly was, has a very extraordinary aspect upon the Journals. But the following account of it, which Lord Mountmorres had from Lord Pery, afterwards Speaker of the House of Commons, who was the Member alluded to in this resolution, contains not only a curious Parliamentary anecdote, but also throws a fresh light on the resolution. Mr. Pery had made a proposition relative to the construction of Poynings' Law, which had produced a debate, in the course of which Mr. Malone happened, unguardedly, to say, " That the gentleman would do well to take care of what he said or what he proposed, because he might be involved in the penalties of felony." This odd assertion from a man of the greatest weight, knowledge, and character, and who was then, confessedly, the leading Member of that Assembly, had a most extraordinary effect, and, after some warm altercation, Mr. Trench, the Member for Galway, moved the foregoing resolution, upon which the House divided, and, as the current flowed strongly in its favour, and a large body passed through the bar, the Government did not choose to be left in a 
small minority, and Mr. Rigby, the Secretary, followed the affirmatives, and, last of all, Mr. Malone himself, upon which it was declared that the motion was unanimously carried. Mr. Malone, on being asked subsequently how he came to make so extraordinary an assertion, explained it by saying he had made a mistake, and had unguardedly alluded to a provision in the law of I54I, by which those who called in question the validity of that particular Parliament were declared to be liable to the penalties of felony. Lord Mountmorres gives the following short view of the former (between I495 and I782) method of passing laws and holding Parliaments in Ireland, and the practice in this respect of his own time:

Before a Parliament was held, it was expedient, antecedent to 1782 , that the Lord Lieutenant and Council should send over an important Bill as a reason for summoning that Assembly. This always created violent disputes, and it was constantly rejected, as a Money Bill which originated in the Council was contrary to a known maxim, that the Commons hold the purse of the nation, as all grants originate from them, since in early times they were used to consult with their constituents upon the mode, duration, and generation of the supply. Propositions for laws, or Heads of Bills, as they are called, originated indifferently in either House. But it was not till after the Revolution of 1688 that the Heads of Bills were presented. These resembled Acts of Parliament, or Bills, with only this small difference- "We pray that it may be enacted," instead of "Be it enacted." After two readings and a committal, they were recommended to the Privy Council. As, however, they were recommended by one House only, 
it was desirable to induce the two Houses to confer, and to give efficiency to these propositions by a joint recommendation. When the Heads of Bills were peculiarly popular, they were presented by Parliament in a body to the Lord Lieutenant, with a request that he would recommend the measure to the King. In practice, the origination of Bills in the Privy Council was confined to the case of the summoning of a New Parliament. After two readings, and a committal, these Heads of Bills were presented to the Irish Privy Council, and then sent by the Council to England, and were submitted usually by the English Privy Council to the Attorney and Solicitor-General, and they were returned thence to the Irish Privy Council, by whom they were sent to the Irish House of Commons, if they originated there (if not, to the Lords), and after three readings they were sent to the House of Lords, where they went through the same stages, and then the Lord Lieutenant gave the Royal Assent in the same form which is observed in Great Britain. In all these stages in England and Ireland it is to be remembered that any Bill was liable to be rejected, amended, or altered, but that when a Bill had passed the Great Seal of England no alteration could be made by the Irish Parliament.*

By the modification of Poynings' Act, in I782, known as the Yelverton Act, it was not necessary for the Irish Privy Council to certify a Bill under the Great Seal of Ireland as a reason for summoning a Parliament, but it was ordered to be convoked by the proclamation from the Crown as it is summoned in England. Bills, however, originated in either House, and went from one to another, as in England. They were then deposited in the Lords' office, when the Clerk of the Crown took

* Appendix III. 
a copy of them, and this parchment was attested to be a true copy by the Great Seal of Ireland on the left side of the instruments. Then they were sent to England by the Irish Council, and, if they were approved of by the King, the transmiss, or copy, came back with the Great Seal of England on the right side, with a commission to the Lord Lieutenant to give the Royal Assent. All Bills, except Money Bills, remained in the Lords' office, but Bills of Supply were sent back to the House of Commons to be presented by the Speaker at the Bar of the House of Lords for the Royal Assent. It is accordingly manifest that no alteration could be made in Bills except in Parliament, as the record and original roll remains in the Lords' office till it obtains the Royal Assent.

Lord Mountmorres states that it is said that there are very few instances of the rejection of Irish Bills, or of their not being returned from England since 1782, though, doubtless, the royal negative is effective.*

Lord Mountmorres thus, in my judgment, correctly sums up the various alterations in the Irish Constitution, the mode of holding Parliaments in Ireland, and of passing laws.

In early times the Lord Lieutenant gave the Royal Assent, as the King does in England, without any communication with him, or any particular licence.

In the reign of Henry VII. it was provided that all Bills should be previously sent by the Lord Lieutenant and Council to England, which were intended to be passed in any Parliament as a reason for holding the Parliament. $\uparrow$

The extreme inconvenience of this necessary preliminary caused two temporary suspensions of this

$$
\text { * Appendix IV. } \quad \dagger \text { Appendix V. }
$$


law in the reign of his successor, and, in the reign of Philip and Mary, it was enacted that propositions for laws or heads of Bills might be transmitted from the Irish Council during the sitting of Parliament.

This practice, till $17 \delta 2$, founded upon these laws, was that the Council sent over a Bill every new Parliament as a reason for its convention, and also such propositions as were made to them from the two Houses while the legislature was sitting for Acts of Parliament.*

But, in consequence of a law in the said year (Yelverton's Act, passed in 1782), no law could be transmitted to the Council before the meeting of Parliament, Bills passed in Ireland as they do in England, and the Royal Assent was given by the Lord Lieutenant in consequence of a commission similar to that which is made when the King does not think it expedient to give the Royal Assent in person in England. (See Mountmorres' Irish Parliaments, I., pp. 47-65.) (See also Appendix V.)

* Appendix VI. 
III.

\section{THE COMPOSITION OF THE IRISH PARLIAMENT.}

The composition of the Irish Parliament, restrained by Poynings' Law, rendered subordinate to the Parliament of Great Britain by the Statute of George I., and dominated by the master passion of maintaining the "landed interests," may now be sketched in outline. The number of Irish temporal Peers was of a changing character. The Lords Spiritual were 22 in number, 18 Bishops and 4 Archbishops. In the reign of Elizabeth the total number of Irish Temporal Peers was 32. In I68I the number had increased to Ir9, but in $175 \mathrm{I}$ the number of Lords Temporal had dwindled down to 28 . It was not until the reign of George III. that the Irish Peerage became a factor in the work of government by corruption.* Between $175^{1}$ and 1790 the number of Irish Temporal Peers had increased from 28 to 178 , and, at the time of the Union, there were no fewer than 228 Temporal Peers. Irish Peerages were generally conferred as the rewards of political services, and of manipulation of the representation of nomination boroughs in the interests of the Administration of the day. It was, indeed, not unusual to confer Irish Peerages on men who had no connection with Ireland, but who, by becoming Irish Peers, could retain their seats in the British House of Commons. The origin of the Irish

* Mountmorres' Irish Parliaments, II., pp. 21 5-220. 
Peerages of Hotham, Galway, Sheffield, Muncaster, Clive, and many others is due to this practice. It was, moreover, customary to make Irish Peerages the rewards for naval or military services, as in the cases of the Peerages of Hood and Teignmouth, Graves and Radstock. The attendance in the House of Lords was never large. The Englishmen and Scotchmen of the Irish Peerage did not attend, but, strange to say, before the taking of the Oath of Supremacy and the Oath in repudiation of cardinal doctrines of the Roman Catholic Faith were enforced in 1692, Peers could be introduced by proxy. In Strafford's Parliament in 1634, the Lords who had proxies were severally introduced personating those whose proxies they had, and taking their seats according to their relative precedency. "This," says Lord Mountmorres, " is particularly mentioned, because the right of protesting by proxy, which is a custom peculiar to the House of Lords of Ireland, seems to depend upon this circumstance, for, as they personated those Lords, so it seemed to follow that they should act in every respect for their proxies as if they were present, and, among other privileges, had a right to protest" (see Mountmorres' Irish Parliaments, I., pp. 321-322). In Ireland Peerages were conferred avowedly as rewards for support in the Irish House of Commons, and were not infrequently sold for money which was subsequently expended by the Government in bribes to Members of the Irish House of Commons. The conflicts between the Government and the Country or Opposition Party in the House of Commons were followed by profuse creations of Peerages bestowed on Government supporters, to some of which I will subsequently direct attention. To give one or two instances: in 1776 , as the 
result of a contest between the Irish Government and the advocates of popular rights, no fewer than 18 Irish Peers were created in a single day, and 7 Barons and 5 Viscounts were, on the same day, raised a step in the Peerage. "The terms of the bargain were well known to be an engagement to support the Government by their votes in the House of Lords, by their substitutes and their influence in the House of Commons " (Lecky's History of England in the Eighteenth Century, IV., p. 44I). Peerages to the Irish gentry were always a peculiar object of ambition, and they had long been given in Ireland with a lavishness which materially degraded the position. In England the simultaneous creation of 12 Peers by Harley had been regarded as a scandalous and unprecedented straining of the prerogative, but no sooner had the Union been carried than Lord Cornwallis sent to England the names of sixteen persons to whom he had expressly promised Irish Peerages as rewards for their support of the Union. But these promotions were but a small part of what was found necessary. Twenty-nine Irish Peerages were created; 6 Peers received English Peerages on account of Irish services, and 20 Peers received higher titles.* The full list of these " honours" is reproduced in the Cornwailis correspondence.

The House of Lords of Ireland was never in conflict with the House of Commons on cardinal matters of public policy. No Bill of first-class importance before the modification of Poynings' Law in 1782 , passed by the House of Commons, was rejected by the House of Lords. The powers of the Irish and the English Privy

* Lecky's History of England in the Eighteenth Century, VIII., p. 398. 
Councils, by whom the Bills were not returned unless approved by the Government, rendered their rejection unnecessary. Again, after 1782, Bills passed by the House of Commons were not rejected by the House of Lords, because both Houses were of similar, not of contrasted, character, and a majority of the Members of the House of Commons was actually returned to that House by the influences of Peers, who were the patrons of nomination boroughs. Peerages, when conferred on Irishmen, were almost exclusively given to large borough owners, and it was stated in 1783 that 53 Peers nominated 123 Members of the Irish House of Commons, the Lower House being to a great extent the creation of the Upper one (Lecky's History of England in the Eighteenth Century, VI., p. 323).

In the first Parliament of Elizabeth, in 1560 , the number of Members of the House of Commons was 76 , ten only out of the twenty counties which had then been formed receiving a writ of summons (Hallam's Constitutional History, III., p. 367). In the last Parliament of Elizabeth, in 1585 , there were 126 Members of the House of Commons. In the Parliament of James $I$., in 1613 , the number of Members of the House of Commons was 232. In Strafford's Parliament, in 1634 , the Members of the House of Commons numbered 246. In 1666 the number of Members had increased to 276 , and shortly after the Revolution the number of Members was 300 , at which it remained till the Union. Of these 300 Members, 72 only could be regarded, however faintly, as having been returned by a semblance of popular election. The composition of the Irish House of Commons was never better described than by Mr. Hely Hutchinson, who was Provost of Trinity College, Dublin, and holder of 
the position of Secretary of State, in a speech delivered in the Irish House of Commons in 1793, in which, speaking without fear of contradiction to an audience which had special means of information on the subject, in reply to a question he had put to himself : "What is the history of representation in this country ?" he said :

"In the first Parliament of James I., held in $1_{613}$, the numbers of the House of Commons were 232 ; the last creation of a borough was by Queen Anne, who created one only. For the difference between the number of representatives at the accession of James and the present number of 300 , the House of Stuart is responsible. Onehalf of the representatives was made by them, and made by the exertion of prerogative; of these James made 40 at one stroke, most of them on the eve of a Parliament, and some after the writs of summons had been issued. The Commons, in that Parliament, expressed their doubts whether these boroughs had the power of returning Members to sit in Parliament, and reserved that subject for future consideration. Complaints were made to James I. of those grants, but what was his answer ?- I have made 40 boroughs: suppose I had made 400 - the more the merrier !' Charles I. followed the example of his father in exercising this prerogative, but not to so great an extent. Complaints were also made to him, and he gave assurances that the new Corporations should be reviewed by Parliament. The grants made by these two monarchs appear, by the histories and correspondences of those times, to have been for the purpose of giving the Protestants a majority over the Roman Catholics. The grants by Charles II., James II., and Queen Anne proceeded from motives of personal favour. Thus it would appear, if the facts 
were investigated, that one-half of the representation of Ireland had arisen from the exertion of the prerogative, influenced by occasional motives, disputes among religionists, and inducements of personal favour, but had not been derived from any of those sources which had produced the English Constitution. Had he the honour of being a member of the British House of Commons, he would never touch the venerable fabric of their representation, but in this Kingdom the part of the representation universally complained of had originated in party or private motives, and he did not believe there was one prescriptive borough in the whole Kingdom. He believed some boroughs were called so, but he believed, unjustly, eleven of the grants which had been mentioned did not appear at the Rolls Office, but most of them were modern in the time of the House of Stuart." Mr. Hely Hutchinson, had he been as well versed in the history of the British as of the Irish nomination boroughs, would scarcely have expressed his admiration for "the venerable fabric of British representation." In 1785 , Pitt himself had proposed a reform of that representation, in which he had made the suggestion of according compensation for their disfranchisements to the owners of nomination boroughs. Mr. Hallarn, writing in 1816 of the accessions to the British House of Commons of members for boroughs enfranchised by Edward VI., Mary, and Elizabeth, says: "The design of the great influx of new Members from petty boroughs, which began in the short reigns of Edward and Mary, and continued under Elizabeth, must have been to secure the authority of the Government, especially in the successive revolutions of religion. Five towns only in Cornwail made 
returns at the accession of Edward IV.; twenty-one at the time of Elizabeth. It will not be pretended that the wretched villages which corruption and perjury still hardly keep from famine were seats of commerce and industry in the sixteenth century" (Hallam's Constitutional History of England, III., pp. 38-39). A very remarkable document, entitled, "Table of Parliamentary Patronage for Ireland, 1793," published in a periodical of the highest merit in its day, describes concisely, without fear of contradiction, the state of Irish Parliamentary representation within a few years of the passing of the Act of Union. It states that the number of Members of the Irish House of Commons who owed their seats to Peers who were patrons of nomination boroughs was 134, and the number of Members who owed their seats to Commoners who were patrons of nomination boroughs was 94 ; so that, in the Irish House of Commons, which consisted of $300 \mathrm{Mem}$ bers, no fewer than 228 Members (196 of whom were returned for 98 boroughs) were returned either by Peers as their nominees, or obtained their seats by the influence of patrons who were Commoners, while the remaining 72 Members, like the others, represented Protestant constituencies exclusively, the great mass of the population, who were- Roman Catholics, being wholly unrepresented in the Irish House of Commons (Anthologia Hibernica, October, 1793, p. 268 ; see also Madden's United Irishmen, First Series, p. 194). 
IV.

THE IRISH PARLIAMENT AND THE IRISH LAND SYSTEM.

IT is essential, in estimating the work of the Irish Parliament, and in considering its occasional attacks on the principles of national liberty, and fair dealings between man and man, to bear in mind that that Parliament was composed exclusively of men who were, directly or indirectly, interested in the maintenance of the land system, popularly, but incorrectly, known as the Cromwellian settlement in Ireland, which, by a series of confiscations, placed the land of the country in the hands of a few, and had despoiled its former owners of their proprietary rights. This land settlement has been the chief cause of the political and social evils of Ireland is accountable for the deep and lasting division between the English and Scotch settlers and the native population from the period of the Reformation to that of the Revolution, and for the religious intolerance which found its expression in the Penal Code. Burke, who studied Irish history with much care, has noticed how its "real clue," from the accession of Elizabeth to the Revolution, is to be found in the confiscation of Irish land by English and Scotch adventurers, and the rooting out from the soil of the native inhabitants and of the descendants of the old Anglo-Norman families who had settled in Ireland from the time of Henry II. In a letter 
to Sir Hercules Langrishe, in I79x, Burke says : "We cannot miss the true genius and policy of the English Government in Ireland before the Revolution, as well as during the whole reign of Queen Elizabeth.

The original scheme was never deviated from for a single hour. Unheard-of confiscations were made in the Northern parts upon grounds of plots and conspiracies, never proved, upon their supposed authors. The war of chicane succeeded to the war of arms, and of hostile statutes, and a regular series of operations was carried on, particularly from Chichester's time, in the ordinary Courts of Justice and by special commissions and inquisitions, first under the pretence of tenures, and then of titles in the Crown, for the purpose of the total extirpation of the interests of the natives in their own soil, until this species of subtle ravage, being carried to the last excess of oppression and insolence under Lord Strafford, it kindled the flames of that Rebellion which broke out in $164 \mathrm{I}$. By the issue of that war, by the turn which the Earl of Clarendon gave to things at the Restoration, and by the total reduction of the Kingdom of Ireland in $169 \mathrm{r}$, the ruin of the native Irish, and, in a great measure, too, of the first races of the English, was completely accomplished."* The causes which produced the Rebellion of $\mathrm{r} 64 \mathrm{I}$ were agrarian and religious. "It had become clear," writes Lecky, " beyond all doubt, to the native population, that the old scheme of "rooting them out' from the soil was the settled policy of the Government, that the land that remained to them was marked as a prey by hungry adventurers, by the refuse

* Edmund Burke on Irish Affairs, edited by M. Arnold, pp. 24 I242. See Lecky's History of England in the Eighteenth Century, II., pp. 102-103. 
of the population of England and Scotland, by men who cared no more for their rights and happiness than they did for the rights and happiness of the worms which were severed by their spades."* Not only their land, but their religion was in peril. The overwhelming majority of the old English settlers and whole native population remained attached to the Roman Catholic Faith. The property of the Roman Catholic Church had been confiscated, and all religious worship, except the Anglican, was made illegal ; but the Roman Catholic worship had, in practice, been tolerated. The strengthening of the Protestant interest in Ireland was the one great object of the Plantation in Ulster. Irish Protestant Prelates preached vehemently against toleration, and the English House of Commons supported them by a remonstrance to Charles I., complaining bitterly that the Popish religion was publicly professed in every part of Ireland, and that monasteries and nunneries were then newly erected. "The primary causes of the rebellion are to be found," writes Hallam, " in the two great sins of the English Government in the penal laws as to religion, which pressed on almost the whole people, and in the systematic iniquity which despoiled them of their possessions." $\rightarrow$ The effect of the Acts of Settlement and Explanation, whereby the title to lands in Ireland was settled, as a sequel to the Rebellion of 1641 , the Cromwellian régime and the Revolution, was that, at the end of the seventeenth century, the Irish and Anglo-Irish Roman Catholics hardly possessed above one-seventh of the Kingdom. They were, however, very formidable from their numbers,

* History of England in the Eighteenth Century, II., pp. Ir7-I I8.

$\dagger$ Hallam's Constitutional History, III., p. $390^{\circ}$ 
and the victorious or Protestant Party saw no security for their land but in a system of oppression contained in a series of laws during the reigns of William and Anne, which has no parallel in European history * What powerful factors the Cromwellian settlement and the fear of its disturbance proved themselves to be in resistance to Irish rights and liberties, may be seen from the manner in which they were utilised by Lord Clare, the principal machinator after Lord Castlereagh in Ireland of the Union, in his celebrated speech in advocacy of the Union, delivered in the House of Lords, when Lord Chancellor of Ireland, on the roth February, 1800. The pronouncement is most valuable to the student of history as an exposition of the effect of the "Cromwellian settlement" on the trend of Irish politics, and justifies the reproduction of a lengthy quotation therefrom :

"Cromwell's first act," says Lord Clare, "was to collect all the native Irish who survived the general desolation, and remained in the country, and to transplant them into the Province of Connaught, which had been completely depopulated and laid waste in the progress of the Rebellion. They were ordered to retire there by a certain day, and forbidden to repass the Shannon on pain of death, and this sentence of deportation was rigorously enforced till the Restoration. Their ancient possessions were seized and given up to the conquerors, as were the possessions of every man who had taken part in the Rebellion or followed the fortunes of the King after the murder of Charles I. And this whole fund was distributed amongst the officers and soldiers of Cromwell's army in satisfaction of the arrears of their pay, and adventurers who had advanced money to

* Hallam's Constitutional History, p. 430. 
defray the expenses of the war. And thus a new colony of new settlers, composed of the various sects which then infested England-Independents, Anabaptists, Seceders, Brownists, Socinians, Millenarians, and Dissenters of every description-many of them infected with the leaven of democracy, poured into Ireland, and were put in possession of the ancient inheritance of its inhabitants. And I speak with great personal respect of these men when I state that a very considerable portion of the opulence and power of the Kingdom of Ireland centres at this day in the descendants of this motley collection of English adventurers.

"It seems evident, from the whole tenor of the declaration made by Charles II. at his restoration, that a private stipulation had been made by Monk in favour of Cromwell's soldiers and adventurers, who had been put into possession of the confiscated lands in Ireland, and it would have been an act of gross injustice on the part of the King to have overlooked their interests. The civil war of 1641 was a rebellion against the Crown of England, and the complete reduction of the Irish rebels by Cromwell redounded essentially to the advantage of the British Empire. But, admitting the principle to its fullest extent, it is impossible to defend the Acts of Settlement and Explanation, by which it was carried into effect, and I could wish that the modern assertors of Irish dignity and independence would take the trouble to read and understand them.

"I will not detain the House with a minute detail of the provisions of this Act, thus passed for the settlement of Ireland, but I wish gentlemen who call themselves the dignified and independent Irish nation to know that seven million eight hundred thousand acres of 
land were set out under the authority of this Act to a motley crew of English adventurers, civil and military, nearly to the total exclusion of the old inhabitants of the island, many of whom, who were innocent of the Rebellion, lost their inheritances as well, for the difficulties imposed upon them by the Court of Claims in the proofs required of their innocence, or from a deficiency in the fund for reprisal to English adventurers arising principally from a profuse grant made by the Crown to the Duke of York; and the Parliament of Ireland, having made this settlement of the island in effect on themselves, granted an hereditary revenue to the Crown. It is a subject of curious and important speculation to look back to the forfeitures of Ireland incurred during the last century. The superficial contents of the island are calculated at $I I, 420,682$ acres. Let us now examine the state of forfeitures :

Confiscated in the reign of James I., the whole Province of Ulster, containing $\ldots \ldots \ldots \ldots \ldots \ldots$ Set out by the Court of Claims at the Restoration ............ Forfeitures of 1688 $2,836,837$ acres. $7,800,000$ acres. 1,060,792 acres.

$$
\text { Total } \ldots \ldots \ldots \quad \text { I }, 697,629 \text { acres. }
$$

"So that the whole of your island has been confiscated, with the exception of the estates of five or six old families of English blood, some of whom had been attainted in the reign of Henry VIII., but recovered their possessions before Tyrone's rebellion, and had the good fortune to escape the pillage of the English Republic 
inflicted by Cromwell, and no inconsiderable portion of the island has been confiscated twice or, perhaps, thrice in the course of a century. 'The situation of the Irish Nation at the Revolution stands unparalleled in the history of the inhabited world.

"What, then, was the situation of Ireland at the Revolution, and what is it to-day? The whole power and property of the country has been conferred by successive monarchs of England upon an English Colony composed of three sets of adventurers who poured into this country at the end of three successive rebellions; confiscation is their common title, and, from the first settlement, they have been hemmed in on every side by the old inhabitants of the island, brooding over their discontent in sullen indignation."

The speech of Lord Clare, which was a most forcible Unionist appeal, both to the self-interest and to the fears of the Protestant population of Ireland, who were apprehensive of the resumption of the confiscated lands by the mass of the people, whe, having been admitted to the Parliamentary elective franchise since 1793, were clamouring for a comprehensive scheme of Parliamentary Reform, and for securing the eligibility of Roman Catholics to sit and vote in Parliamentmeasures that could not long be deferred. It is, moreover, a skilful and accurate statement of the position of the Irish Parliament, subject to galling restrictions by the British Government and the British Parliament, and, while humiliated by this lack of independence, fearful of making common cause with their Catholic fellow-countrymen, owing to the enjoyment of privileges founded in injustice and secured them by the English Government, to whom, in the words of 
Shiel, they "knelt on the necks of their Roman Catholic fellow-countrymen."

The fact that most of the country was held by the title of recent confiscations was itself a deterrent to every project for the amelioration of the condition of the people. To give an illustration: In 1709 the Irish House of Commons presented an address to Queen Anne, strongly urging the fatal consequences of reversing the outlawries of any persons who had been attainted for the rebellions either of $164 \mathrm{I}$ or of 1688 , on the ground that any measure of clemency would shake the security of property. "The titles of more than half the estates," they said, " now belonging to the Protestants, depend on the forfeitures of the two last rebellions, wherein the generality of the Irish were engaged." Mr. Lecky well observes that this fact lies at the very root of the social and political history of Ireland (History of England in the Eighteenth Century, II., p. 286).

The Irish Land Question has now been happily settled by the transfer of the land to the occupiers thereof, but dread of the disturbance of the Cromwellian Settlement was, for upwards of two centuries, a powerful factor in opposition to Irish rights and liberties, and a specious plea for religious intolerance. So recently as November, 1873, Mr. Isaac Butt, in formulating his proposal for the establishment of an Irish Parliament on a Federal basis, placed in the series of resolutions in which that proposal is embodied a declaration of readiness to insert in the Federal Constitution "guarantees against any disturbance of the present settlement of property, or any establishment of a religious ascendancy." That resolution, it is of interest to record, was proposed by the late Mr. W. A. Redmond, M.P., 
the father of the Leader of the Irish Parliamentary Party. Mr. Butt then said: "The settlement of property is a phrase familiar to all who are acquainted with the Irish Statute Book. It has reference to the Act passed in the reign of Charles II., confirming the titles of the forfeited estates. Immediately before that Statute there had been a great and a very violent transfer of property from the old Catholic proprietors to the Protestant adventurers who fought under Cromwell. This was, in fact, the Cromwellian Settlement of Ireland-a settlement which is the origin of the title to a large portion of the landed property in Ireland. Something of the same kind, but to a more limited extent, occurred in the reign of William III. After the Revolution the new proprietors had an apprehension, perhaps not an unnatural one, that if ever the Catholics obtained power their forfeitures would be reversed. They had, in fact, been so by the Catholic Parliament of King James. With every relaxation of laws against Catholics, with every concession that admitted them to civil rights, an oath was demanded of them that they would not interfere with ' the settlement of property now existing by law.' That oath was continued till within the last few years, and there are gentlemen in this room who have taken it as their title to be members of a Corporation. Two hundred years have passed away since these confiscations. Property has changed hands ; Catholic gentlemen are themselves the proprietors of the forfeited estates, and it is almost childish to talk of protecting 'the Act of Settlement and Explanation.' But prejudices remain long after the cause which has excited them has passed away."

The dread of the disturbance of the Cromwellian Settle- 
ment, which produced the atrocious Penal Code, is, no cloubt, accountable for the harsh and reproachful epithets of 'Papist,' 'Popish,' 'Romist,' 'Romanist,' etc., etc., which appear in the Statute Book. From the time of the introduction of the Protestant creed into Ireland, the appellation of Roman Catholics used by the Statutes appears to have been merely that of 'persons in communion with the Church of Rome.' From 1692, in the commencement of the reign of William III., when the Catholics were expelled from the Irish Parliament, a more hostile and contemptuous phraseology then appeared. From that time till 1792 the Statutes describe them as 'Papists,' 'Popish People,' etc." The later Statutes, notably the Relief Act of 1792, drop the harsher phrases altogether, and term them "Roman Catholics" only. "In the first Viceregal speech in 1793 the qualification was dropped, and for the first time since the Par-. liament of James II. the term ' Catholic' was employed from the 'Throne" (Scully's Irish Penal Laws, Lecky's History of England in the Eighteenth Century, VI., p. 563). 
V.

EARLY STRUGGLES IN IRISH PARLIAMENT FOR POPULAR RIGHTS.

Mr. LeCKY has stated that it has always seemed to him one of the most striking instances on record of the facility with which the most defective Parliament yields to popular impulses, and acquires an instinct for independence, that the Irish Parliament, which was so completely subservient to English influence, so wholly dependent on the Parliament of England, should have ever constituted itself on any single subject a faithful organ of public opinion, or succeeded in winning any concessions to the cause of popular rights and liberties. As in England, so also in Ireland; popular rights were established by the power of the purse. The English Parliament, though it assumed and repeatedly exercised the right of binding Ireland by its legislation, refrained from imposing taxation on that country. The early struggles of the Irish Parliament in the assertion of its independence turned on questions of finance, although the larger part of the revenue was entirely beyond the control of Parliament. The insufficiency, however, of the revenue, which laid, as we shall see, from the first, the foundation of the power of the Irish Parliament, rendered it necessary to ask for supplies, and, in this manner, conferred power on the Irish Parliament. In Ireland, as in England, Parliaments were convened by the Crown 
to obtain money, of which the Government stood in need, although in Ireland, as in England, attempts were made-some of them successful-for considerable periods of time to govern Ireland without Parliament, by financing the administration of the Crown out of the hereditary revenue. Mr. Lecky, in his account of the Irish revenue after the Revolution, explains clearly the relationship between the deficiency of that revenue and the convening of Parliaments, which can be seen to prevail throughout the history of the Parliaments of Ireland. This hereditary revenue of the Crown in Ireland, as it existed after the Revolution, rested, he tells us, substantially on the legislation of Charles II. (the Acts of Settlement and Explanation with the Quit Rents, and the Act for the Abolition of Feudal Tenures), and it grew in a great measure out of the confiscations after the Rebellion. "The lands which had then been forfeited by the Irish, and which were not restored by the Act of Settlement, had been bestowed during the Commonwealth on English soldiers. If the Crown, at the Restoration, had exercised its legal right of appropriating them, it would have obtained a great revenue, but, as such a course would have been extremely difficult and dangerous, it was arranged by the Act of Settlement that the Crown should resign its right to these forfeitures, receiving in compensation a new hereditary revenue. The older forms of Crown property were, at the same time, either incorporated into this revenue, or abolished with compensation, and the new hereditary revenue, as settled by Parliament, was vested for ever in the King and his successors. It was derived from many sources, the most important being the Crown rents, which were chiefly from the confiscations of Henry VIII., 
and from the six counties which were forfeited after the Rebellion of Tyrone; the quit rents, which had their origin in the confiscations which followed the Rebellion of $164 \mathrm{I}$; the hearth money, which was first imposed upon Ireland under Charles II.; licences for selling ale, beer, and strong waters, and many Excise and Customs House duties. For many years the revenue was sufficient for all the civil and military purposes of the Government, and no Parliament, with the exception of that which was convoked by James II., after his expulsion from England, sat in Ireland for the thirty-two years that elapsed between the Restoration and the Parliament which was summoned by Lord Sydney in $1692 . " *$

In Ireland, as in England, the Tudors laid great stress on obtaining, for the objects of public policy on which they had set their hearts, a formal Parliamentary sanction. The Reformation, accompanied with the abjuring of their ancient religion, was hateful to the people of Ireland. That movement had in England undoubtedly a considerable measure of support, whereas in Ireland it was without a friend. The Bishops, with the Primate, Cromer, at their head, and the Lords and Commons, in a Parliament held in Dublin in $153^{6}$, resisted the Act of Supremacy, which was, nevertheless, carried by the force of the Crown, absolutely coercing the Parliament. In the reign of Edward VI., however, it appeared dangerous to summon a Parliament, and the English liturgy was oriered by a royal proclamation, while, in Mary's reign, with the willing aid of an Irish Parliament, the old system was restored. In the first 224.

* Lecky's History of England in the Eighteenth Century, II., pp. 223- 
Parliament of Elizabeth, in 1560 , the Protestant Church was established by Statute, care having been taken by the enfranchisement of boroughs and the manipulation of the county representation to procure a Parliamentary majority for that purpose. Ten only out of the twenty counties which had then been formed received the Writ of Summons, and the number of seventy-six representatives of the Anglo-Irish people was made up by the towns, many of which were avowedly under the influence of the Crown, which had been enfranchised for the purpose of placing in the House of Commons dependants and henchmen of the Crown, by whom the compulsory establishment of the Protestant Church was secured (Hallam's Constitutional History, III., pp. 366-367). In the next Parliament of Elizabeth, held in 1569 , there is a distinct formation of a Parliamentary opposition. A strong Country party was formed in opposition to the Crown, and that opposition made itself effective in the domain of finance, while keenly alive to other grievances. They complained of the management by which irregular returns of Members had been made, and that some mere English strangers had been returned for places which they had never seen. The Judges, on reference to their opinion, declared that in cases in which the towns were not incorporated, and in which sherifis had returned themselves, the elections were illegal, but confirmed the non-resident burgesses, which still left a Court majority. After this preliminary discussion the Country party opposed unsuccessfully a Bill for the suspension of Poynings' Law, an incident which shows that upwards of seventy years after its enactment that measure was still regarded as a bulwark of Parliamentary liberty, and a new tax on wines. The assertion of the 
power of the purse was met by a Mr. Hooker, who sat for Isleworth in the English and for Athenry in the Irish House of Commons, and to whom we are inciebted for one of the earliest records of Parliamentary practice and procedure by the statement that "Her Majesty, of her own royal authority, might and may establish the same without any of your consents, as she hath already done the like in England, saving of her courtesy it pleaseth her to have it pass with your own consents by order of law, that she might thereby have the better trial and assurance of your dutifulness and good will towards her." This language produced an uproar which rendered it necessary that the House should be adjourned, and that Mr. Hooker should be protected by a guard. The duty on wines was laid aside for a time, but was carried in a subsequent Session.*

Closely connected with the acquisition of the power of the purse is the doctrine that no tax can be imposed or levied without the consent of Parliament. This doctrine was boldly advocated in 1576 , not in Parliament, but from without. "It had long been usual to obtain a sum of money for the maintainance of the household and of the troops by an assessment settled between the Council and the principal inhabitants of each district. This, it was contended by the Government, was in substitution of the contribution of victuals which the Queen, by her prerogative of purveyance, might claim at a fixed rate, much lower than the current price. It was maintained, on the other side, to be a voluntary benevolence. Sidney, the Lord Deputy, now devised a plan to change it for a permanent composition for every plough land, without regard to those who claimed exemption from the burden of pur-

\footnotetext{
* Hallam's Constitutional History, III., pp. 372-373.
} 
veyance, and imposed this new tax by Order in Council as sufficiently warrantable by the royal prerogative. The landowners of the Pale remonstrated against such a violation of their franchise. They refused compliance with the demand, and alleged it was contrary both to reason and to law to impose any charge upon them without the consent of Parliament. A deputation was sent to England in the name of all the subjects of the English Pale. After some demonstrations of resentment in committing the delegates to the Tower, Queen Elizabeth compromised the matter by the acceptance of a voluntary composition in the accustomed manner for seven years (see Hallam's Constitutional History, III., pp. 373-374).

In the reign of James $I$. a fear of Parliamentary opposition to the policy of the Crown is plainly perceptible. The King's Writ was obeyed at least in profession throughout Ireland, and English law was established in every quarter of the country. The difficulty, however, of obtaining the sanction of Parliament to the settlement of Ulster was very serious. Sir John Davies, the Speaker of the Parliament convened by James I. in 1613 , gave in his speech to the Lord Deputy, Sir Arthur Chichester, a history of the Parliaments of Ireland, and stated that in seventeen counties out of the thirty-two into which Ireland was finally parcelled, there was no town that returned burgesses to Parliament before the reign of James I., and the whole number in the rest was about 30 . James I. took the short and easy course of making the Irish Parliament answerable to "regal influence"- to use the term in vogue in a later generation by the enfranchisement of nomination boroughs for the purpose of swamping 
honest representation. In James's Parliament of $16{ }_{3}$ there were 106 more Members of the House of Commons -which consisted of 234 Members-than in its immediate predecessor, Perrot's Parliament, of 1585 . Of these, upwards of 80 were from the new boroughs created by James. Without the new boroughs the Irish, as distinguished from the Recusants, would have had a majority -as it was. they numbered ror (Ball's Legislative Systems, p. 223). Forty boroughs, as we have seen, were created in a single day, consisting for the most part of townships where towns were projected but not built, or of groups of three or four houses inhabited by a dozen or so of new settlers, to whom, in some cases, a charter had not been issued. "These boroughs were authorised to select two Members each, and, when the new Parliament met, 200,000 English and Anglo-Irish of the religion of the Court were found to have more representatives than the Irish nation six times their number. The Members for the new boroughs were not likely to be troublesome to the Crown; they were chosen from the Lord Deputy's servants, attorneys' clerks, bankrupts, outlaws, and other persons in a servile or dependent condition (Davis's Patriot Parliament, edited by Sir C. G. Duffy, Introduction, pp. xix.-xx.). This proceeding was the subject of the protest of the authentic representatives of the people, who sent agents to James to complain of the abuse of the Royal Prerogative, while the Lords of the Palc, in a letter to the King, couched in highly-constitutional language, expressed their apprehension that the erecting of so many insignificant places to the rank of boroughs was calculated to frustrate the general scope and institution of Parliament, they being ordained for the 
assurance of the subjects, not to be pressed with any new edicts or laws, but such as should pass with their general consents and approbations. "What is it to you," replied the King, " whether I make many or few boroughs? My Council may consider the fitness if I require it. But, what if I had created 40 noblemen and 400 boroughs? The more the merrier; the fewer the better cheer" (Hallam's Constitutional History, III., p. 383). The subject of the new boroughs was brought under the notice of the House of Commons, but Sir John Davis, the Speaker, whose election to the Chair was bitterly contested by the Patriot Party, devised a diplomatic method of shelving the thorny question. "Under his direction," writes Sir Charles Gavan Duffy, "the House of Commons confessed the wrong, but evaded the remedy. It was true that many Members were 'unduly elected' ; some (as the resolution recited) for 'not being estated in their boroughs, some for being outlawed, excommunicated, and, lastly, for being returned for places whose Charters were not valid.' It would greatly prejudice public business, however, to create a delay just then ; therefore, the returns should not be questioned, but this resolution must not, of course, be drawn into a precedent. The native Members withdrew in a rage (a notable instance of the secession from the House of Commons of an Opposition), and the representatives of the boroughs 'whose Charters were not valid,' the bankrupt, outlawed, and excommunicated nominees of the Castle, declared the territory of O'Neill and O'Donneil forfeited to the Crown." "Such a Parliament," Sir C. G. Duffy proceeds, " could scarcely be improved upon, and, when leisure came, the fraudulent boroughs were 
never called in question. They were not called in question, indeed, but carefully maintained by successive Sovereigns and Governments as a means of keeping Parliaments in order" (Davis's Patriot Parliament, edited by Sir C. G. Duffy, Introduction, pp. xxi.xxii.). The fraudulent boroughs were even increased, for the House of Commons was subsequently augmented, and reached its full complement, as I have said, shortly after the Revolution. These grants of the elective franchise Hallam considers to have been made, not, indeed, improvidently, but " with very sinister intents towards the freedom of Parliament, two-thirds of an Irish House of Commons, as it stood in the eighteenth century, being returned with the mere farce of election by wretched tenants of the aristocracy." (See Hallam's Constitutional History, III., pp. 383-384.)

In the Parliaments of Charles I., despite their crippled powers and essentially corrupt constitution, there is evidence of strong opposition to the iron hand of power, and deep-seated resentment at the breaches of faith by the King and his Ministers with the people. The Parliament of 1634 struggled to secure the Parliamentary confirmation of the "Graces" concessions to liberty, which Hallam terms the analogue of the Petition of Right in England, which had already been paid for by the people, in reliance on the promise of Charles I. that these concessions-reformations of unquestionable and intolerable grievances-would be secured by Act of Parliament.* The Parliament assembled by Strafford in 1640 , after his recall from the Lord Lieutenancy, made a manful assertion of Irish Parliamentary independence, of which, as I have mentioned, one of the articles of Strafford's impeach-

* Yallam's Constitutional History, III., pp. 383-384. 
ment is an echo, and a remonstrance of the Irish House of Commons presented to the Long Parliament exhibits in the catalogue of grievances therein detailed, in the words of Hallam, a true picture of the misgovernment of Ireland at all times, especially under Strafford. As both Parties-the Country or National Party and the Party of the Settlers-acted together in the framing of this remonstrance, temporarily waiving religious differences, it may be regarded as an evidence of the power of a body, despite the drawbacks to which the Irish Parliament was subject, being the semblance of the mouthpiece of a nation's will to unite in defence of the liberty of its citizens of every creed and race and party which was threatened with extinction. Mr. Lecky strongly censures the conduct of Parsons and Borlace, the Lords Justices, in proroguing the Irish Parliament on the outbreak of the rebellion of 1641 , " contrary to the strong remonstrances both of Ormonde and of the Catholic Party at a time when its continuance was of vital importance to the country." It contained a large proportion of those who were subsequently leaders of the rebellion, but " it showed itself strongly and unequivocably loyal, and at a time when the Puritan Party was rising into the ascendant, and when there was a great and manifest disposition to involve as many landed proprietors as possible in the guilt of the rebellion, the Catholic gentry regarded this Parliament as their one means of attesting their loyalty beyond dispute, and protecting in some degree their properties and their religion" (History of England in the Eighteenth Century, II., p. 126).

After the Restoration, on the 8th May, 166I, a Parliament was called by Charles II. in Ireland, whose 
first business was, as I have mentioned, to carry the comprehensive measure-the Act of Settlement-and to maintain it by the Act of Explanation. To the carrying of this legislation, not by an English, but by an Irish Parliament, owing to the sapient counsel of Lord Chancellor Nottingham, that the laws of England would only be binding by sufferance and protest by adoption in Ireland, I have previously called attention, as a significant pronouncement by one of the most acute and profound lawyers of his time of Ireland's exclusive right to legislate for herself. The Corporations of Ireland had been filled with Protestants by Cromwell, and the Irish House of Commons, at the Restoration, was purely Protestant. That House had, however, a keen but mistaken sense of its dignity, and a jealousy of its privileges, which, indeed, was a uniform characteristic of every Irish House of Commons, however unrepresentative of the people it may have been, and became in itself a very powerful factor in the achievement of the liberty of the people. The Parliament of Charles II.-the only Parliament of his reign-was dissolved in 1666 , and no Parliament (with the exception of the Parliament of James II., after his deposition from the Throne in 1689) was summoned till after the Revolution in 1692 . The dissolution of 1666 was occasioned by a squabble between the two Houses on points of idle etiquette and worthless ceremony with respect to the formalities to be observed by Members of both Houses respectively, in sitting down, in standing up, the place for the Commons to approach, whether the Peers should be allowed to sit covered while the Commons were to be allowed to stand uncovered. When Strafford was Lord Lieutenant, a stupid quarrel of a similar nature 
was adjusted by his tactful suggestion that the usage of the English Parliament, with which, as an old Member, he was well acquainted, should be followed. In 1666 the Duke of Ormonde, who was then Lord Lieutenant, through inability to compose the differences between the Houses, dissolved the Parliament. In a later generation, in 1737 , Conferences between the two Houses were discontinued owing to quarrels on points of etiquette and ceremonial. This morbid sensibility of the House of Commons in the assertion of its privileges, ridiculous as it may seem to us, was not, as I have said, without benefit to the people at large. Privilege can only be maintained by power, and it was early perceived that the power of the House of Commons waned or waxed in accordance with the favour in which it was held by the people. 
THE IRISH PARLIAMENT OF 1689.

THE accurate constitutional historian would be constrained to record that from $\mathrm{x} 666$ till $\mathrm{I} 692$ no Parliament was convened in Ireland. Just as in England, the later proceedings of the Long Parliament and the Parliaments of the time of the Commonwealth are regarded as nullities, so the Parliament convened in Ireland by James II., which sat in Dublin from May 7 th till July 2oth, I689, after the flight of James from England on December 23rd, 1688 , and after the declaration of the Convention Parliament against James and his family, and for William and Mary on the 12th February, 1689, was likewise a nullity. All the Acts and other official documents of this Parliament were ordered by William's Parliament to be burned by a clause in an Act unmaking its legislation.

It is, however, absolutely essential to a true understanding of the trend of Irish constitutional history to bear in mind the profound effect produced by the proceedings of this Parliament in increasing the hostility of the Landed Interest to any measure of reform under the belief that reform would be calculated to weaken that interest, and, likewise, in forecasting Irish Legislative Independence, which was not attained till $\mathbf{1 7 8 2}$, and universal religious toleration, with the relief of all religious disabilities, which, even at the present time, 
has not been completely achieved. This Irish Parliament of 1689 , nullity though it was according to the letter of the Constitution, held up to execration and misconstruction as it has been for upwards of two centuries, has been thus, in my judgment, correctly described :

"It was the first and the last Parliament which ever sat in Ireland since the English invasion possessed of national authority and complete in all its parts. The King, by law and in fact, the King who, by his Scottish descent, his creed, and his misfortunes, was dear (mistakenly or not) to the majority of the then people of Ireland, presided in person over that Parliament. The Peerage consisted of the best blood, Milesian and Norman, of great wealth and of various creeds. The Commons represented the Irish septs, the Danish towns, and the Anglo-Irish counties and boroughs. No Parliament of equal rank, from King to Commons, sat here since-none sat here before or since so national in composition and conduct" (Davis's Irish Patriot Parliament of 1689, pp. 39-40).

The Lords who sat in this Parliament were 54 in number, of whom six were Protestant Bishops-no Catholic Prelate was admitted at all-and 4 or 5 Protestant Temporal Lords. The Members of the House of Commons were 224, of whom 6 were Protestants. The Corporation Boroughs, which were created originally for the purpose of maintaining royal influence, were, no doubt, tampered with in the interests of James, and most of the important Protestant landlords had either gone over to the Prince of Orange, or fled to England, or, at least, resolved to withdraw themselves from public affairs till the result of the struggle was determined. 
"The Members of the House of Commons were, in many cases, the sons of the 3,000 proprietors who, without trial and without compensation, had been deprived by the Act of Settlement of the estates of their ancestors. 'To all of them the confiscations of Ulster, the fraud of Strafford, the long train of calamities that followed, were cruel and recent events."* A main object of the Parliament was to re-establish, at all costs, the descendants of the old proprietors in their land, and to annul the spoliations of the past. The repeal of the Acts of Settlement and Explanation by this Parliament must, writes Mr. Lecky, be judged "in the light of the antecedent events of Irish history, and with a due allowance for the passions of a civil war, for the peculiar position of the legislators, and for the extreme difficulty of all legislation on the subject." $\dagger$ It was enacted that all persons who had possessed landed property in Ireland on October 22nd, 164I, and who had been deprived of their inheritance by the Act of Settlement, should enter at once into the possession of their old properties. The owners, who were the adventurers or soldiers of Cromwell, were to be dispossessed without compensation, but persons who came into possession of the lands after the Act of Settlement for good and valuable considerations, and not considerations of blood, affinity, or marriage, were to be compensated out of the forfeited estates of Irish proprietors who did not acknowledge King James, or who aided, abetted, or corresponded with the rebels. Davis, while allowing the justice of this restoration of the Irish, admits that the Act contains no provision for the families of these adventurers who, however guilty when they came into the country, had

-Lecky's History of England in the Eighteenth Century, II., pp. I 8 I - I 82 †Lecky, II., p. 187 . 
been "in it for from thirty to forty years, and had time and some citizenship in their favour." "Yet," he proceeds, "let anyone who finds himself eager to condemn the Irish Parliament on this account read over the facts that led to it, namely, the conquest of Leinster before the Reformation, the settlements of Munster and Ulster under Elizabeth and James, the governments of Strafford and Parsons and Borlace, Cromwell's and Ireton's conquests, the effects of the Act of Settlement, and the false plot of the reign of Charles II.- - let them, we say, read these, and be at least moderate in censuring the Irish Parliament of 1689" (Patriot Parliament, pp. 72-73).

I have dwelt at length on this legislation which the triumph of the Williamite cause rendered futile, because it was a powerful factor in the formation of the attitude of obstinate resistance to every movement likely to endanger or even to weaken the landed interest, as established by the Act of Settlement. When, in the 'forties of the eighteenth century, Lord Clancarty succeeded in inducing the English Cabinet to consent to a Bill for reversing his attainder, and restoring property of the estimated value of $f 60,000$ a year, the indignation of the Irish landowners led to the abandonment of the measure by the Government, while the Irish House of Commons showed its feelings by angry resolutions.* The Act of Attainder, by which more than 2,000 men were conditionally attainted unless they appeared during an assigned interval before the law courts for trial, was really designed for the purposes of confiscation, and was passed by a Parliament composed of the representatives of the 3,000 men who had

* Lecky's History of England in the Eighteenth Contury', II., p. 429. 
been absolutely deprived of their possessions without trial in 1665. "It is indeed," writes Mr. Lecky, " a curious illustration of the carelessness or partiality with which Irish history is written, that no popular listorian has noticed that five days before this Act, which has been described as without a parallel in the history of civilised countries, was introduced into the Irish Parliament, a Bill, which appears in its essential characteristics to have been precisely similar, was introduced into the Parliament of England, that it passed the House of Commons, that it passed with slight amendment the English House of Lords, and that it was only lost in its last stage by a prorogation. This fact will show how far the Irish Act of Attainder was from bearing the unique character that has been ascribed to it" (see Lecky's History of England in the Eighteenth Century, II., pp. 193-195; see also Davis's Patriot Parliament of 1689, pp. 142-146).

The Act of Attainder, under whose operation it is not alleged that even one person lost his life, must be regarded as a corollary of the Act repealing the Act of Settlement, its true aim being a complete overthrow of the existing land system in Ireland, and as one of the series of circumstances which made landlords regard themselves as engaged in a life and death struggle in defence of a threatened and hated institution. Although a terrible Penal Code was enacted as a prop and stay of landlordism, it is safe to say that into what we may call the land legislation of James II. the spirit of religious animosity did not enter. To give an illustration: "One Gerard Dillon, a most ferocious papist," writes Archbishop King, " a serjeant-at-law, was Recorder of Dublin, and he stood to be chosen one 
of the burgesses of the City (for the Parliament of 1689), but could not prevail, because he had purchased a considerable estate under the Act of Settlement, and they feared lest this might engage him to defend it." Little value was set on "furious Popery" in comparison with the desire for the resumption of the property plundered by the Act of Settlement.* The Parliament of 1689 , though convened in open defiance of Poynings' Law, and, therefore, illegal, with all its Acts null and void, because unsanctioned by success, was, nevertheless, an epoch-making Assembly, because it enunciated the principal parts of a code of religious and civil liberty needful for the permanent freedom and prosperity of Ireland. James II., in the Speech from the Throne at the opening of the session, said: "I have always been for liberty of conscience, and against invading any man's property, having still in my mind that saying in Holy Writ, 'Do as you would be done to, for that is the Law and the Prophets.' . . . . Nothing shall ever persuade me to change my mind as to that, and, wheresoever I am the master, I design (God willing) to establish it by law, and have no other test or distinction than that of loyalty. I expect your concurrence in so Christian a work." The Parliament, accordingly, by an Act entitled "An Act for Liberty of Conscience and Repealing such Acts and Clauses in any Act of Parliament which are inconsistent with the same," which was far in advance of the age, established perfect religious liberty in Ireland. Although a Roman Catholic Parliament, it proscribed no man for his religion-the word "Protestant" does not occur in any Act, though, while it sat, the Convention Parliament at Westminster was not only thundering out insults against Popery,

* Davis's Patriot Parliament, p. 32. 
but inciting William to persecute it, and laying the foundation of the Penal Code, which was so soon to be enacted by the Parliament of the Revolution régime.* "The Act establishing Liberty of Conscience," writes Mr. Lecky, "in the full flush of the brief Catholic Ascendancy under James II., exhibits very remarkably the tolerant aspect of the Irish character." By yet another Act the Parliament boldly announced Irish Legislative Independence. By the Act declaring that the Parliament of England cannot bind Ireland, and against Writs of Error and Appeal to be brought for removing judgments, decrees, and sentences given in Ireland into England, it " anticipated the doctrine of Molyneux, Swift, and Grattan," and claimed that the .English Parliament had not, and never had, any right to legislate for Ireland, and that none, save the King and Parliament of Ireland, could make laws to bind Ireland. The Houses of Lords and Commons passed a Bill expressly repealing Poynings' Law, which the veto of James II. alone precluded from reaching the Statute Book. That Parliament, too, established religious equality. The voluntary system had no supporters then, and the Irish Parliament did the next best thing-they left the tithes of the Protestant people to the Protestant Ministers, and of the Catholic people to the Catholic Priests. Pensions, not exceeding $£_{200}$ a year, were given to the Catholic Bishops. No Protestant Prelates were deprived of stipend or honour. They held their incomes, and they sat in the Parliament (Davis's Patriot Parliament, Introduction, p. xciii.). Several other measures were passed for the developing of the resources of the country or the remedying of some great abuse. "Among them were Acts for encouraging

* Davis's Patriot Parliament, pp. I5I-I52. 
strangers to plant in Ireland, for the relief of distressed debtors, for the removal of the incapacities of the native Irish, for the recovery of waste lands, for the improvement of trade, shipping, and navigation, and for the establishing of free schools" (Lecky, II., pp. 183-184). The episode of the unacknowledged Irish Patriot Parliament of 1689 most powerfully affected the trend of public opinion in Ireland in the eighteenth century, and must have influenced the course of public men, and moulded their views, whether they happened to belong to the "Court" or to the "Country" or Patriot Party. A general knowledge of the proceedings of this Assembly is, accordingly, essential to an adequate conception of the development of the Irish Constitution, and of the causes which forwarded or retarded its growth. 
THE IRISH PARLIAMENT AS AFFECTED BY PUBLIC OPINION.

THE Irish Parliament which met in 1692 was the first Parliament to be legally convened after the Revolution. The legislation altering the succession of the Crown in England was not re-enacted in Ireland. By the provisions of an Irish Statute (33 Hen. VIII., p. c. I) the King of England is, ipso facto, King of Ireland. The Irish Parliament, by the Act of Recognition (4 William \& Mary, c. I), practically acknowledged England's right in this respect. "The Irish Parliament had never adopted the Act passed in the fifth of Elizabeth, imposing the oath of supremacy upon Members of the Commons. It had been full of Roman Catholics under Queen Elizabeth, James I., and Charles I. In the second Session of 164I, when the Rebellion was at its height, the House of Commons was induced to exclude, by a resolution of their own, all who would not take that oath. In the Parliament of $166 \mathrm{I}$ no Roman Catholic, or only one, was returned, but the House addressed the Lords Justices to issue a commission for administering the oath of supremacy to all its Members. A Bill passed the Commons in 1663 for imposing that oath in future, which was stopped by a prorogation." * An Act, as I have mentioned, of the English Parliament, in 1691 (3 Wm. \& Mary, c. 3),

* Hallan's Constitutional History, III., pp. 40I-402. 
reciting that great disquiret and many dangerous attempts have been made to deprive their Majesties and their royal predecessors of the said realm of Ireland by the liberty which the Popish recusants there have had, and taken to sit and vote in Parliament, requires every Member of both Houses to take the new oath of allegiance and supremacy, and to subscribe the declaration against transubstantiation before taking his seat. To this Statute there was cheerful submission on the part of the Irish Parliament. It was not, however, confirmed by the Irish Parliament till 1782, although it had uniformly been observed. The Irish Parliament seems to have very cheerfully acquiesced in English legislation, which was after its own heart. That Parliament, however, soon came to realise that the Parliament of England had no intention of foregoing or weakening its assumed control over Irish legislation, which was exercised, while the sovereignty was supposed to reside wholly in the King, now that that Parliament had become, in effect and general sentiments, though not quite on the Statute Book, co-ordinate partakers of the supreme authority. Ireland was, for instance, carefully excluded from the chief benefits of the Revolution. An Irish Bill, containing the principal provisions of the Bill of Rights, was sent to England under the Viceroyalty of Sydney in the first Irish Parliament after the Revolution, but was never returned. In fact, Ireland never had a Bill of Rights.* An effort of the Irish Parliament, in 1692 , to obtain the same control over the Irish finances as the English Parliament possessed over the finances of England failed. The jealousy of the English House of Commons at all periods in asserting the absolute right to originate all grants of money and Money Bills is a

* Lecky, II., p. 226. 
representative fact in English constitutional history. The Irish House of Commons contended that Money Bills should originate in their House, although all other Bills must have been certified by the Privy Council. That House, in 1692 , rejected a Money Bill which was sent over from England on the ground that it did not take its rise in the House, and, although on account of an urgent financial necessity, it consented to pass a similar Bill, it accompanied it with a resolution that the other Bill was rejected because it did not take its rise in the House of Commons, and explicitly asserted that " it was the sole and undoubted right of the House of Commons to propose heads of Bills for raising money." The Judges, however, to whom the matter was referred, pronounced adversely to the claim of the House of Commons, while Lord Sydney entered a protest against the proceedings of the House of Commons in the House of Lords' Journals, and prorogued the Parliament, which was soon afterwards dissolved. In the short life of this Parliament there are several indications of the trend of opinion towards legislative independence.*

The Parliament which met in September, 1698 , is signalised by a tragic episode in the history of Ireland. That Parliament was convened for the express purpose of destroying, in the interest of the English commercial classes, the Irish woollen trade, which was the staple industry of the country. There was an important woollen manufacture in England, and the English manufacturers earnestly petitioned for the total destruction of the rising industry in Ireland. Their petitions were speedily considered. Both Houses of the English

*Lecky, II., p. 4I8. Froude, I., pp. 253-256. 
Parliament addressed William III. on this subject on the 9 th June, I 698 , urging him, in the words of the address of the English House of Commons, " to enjoin all those you employ in Ireland to make it their care and use their utmost diligence to hinder the exportation of wool from Ireland, except to be imported hither, and for the discouraging of these woollen manufactures." The King promised to do as he was requested. An Irish Parliament was summoned, being, as we have seen from the nature of its constitution and the circumstances of the country, without power to resist English influence. The Lords Justices, in their opening speech, urged the Parliament to encourage the linen and hempen manufacture instead of the woollen manufacture, which England desired to monopolise. The Commons, in reply, promised their hearty endeavours to establish a linen and hempen manufacture in Ireland, expressed a hope that they might find "such a temperament" in respect of the woollen trade as would prevent it from being injurious to that of England, and proceeded, at the instance of the Government, to impose heavy additional duties on the export of Irish woollen goods. They were in dread of abolition if they refused, and unable to help themselves. This is, however, one of the few instances in which the Irish Parliament was prevailed on to pass laws in restraint of Irish trade. Even in this case the destruction of the woollen industry was not considered complete until English legislation gave it a final blow. The English were still unsatisfied. The Irish woollen manufactures had already been excluded by the Navigation Act from the whole colonial market. They had been virtually excluded from England itself by duties amounting to a prohibition. A law of crushing severity enacted by the British Parlia- 
ment in 1699 completed the work, and prohibited the Irish from exporting their manufactured wool to any other country whatever (Lecky's History of England in the Eighteenth Century, II., pp. 210-211. Froude, I., pp. 292-293).

Submission to the authority of the English Parliament, which was rendered most reluctantly by the Irish Parliament, did not extend to the portion of the Irish people who concerned themselves with public affairs. They were however, almost absolutely helpless, cut off from the great body of the nation, excluded from the highest political and judicial offices, which were all but invariably nilled by Englishmen, and, being in a poverty-stricken country, they could do little but utter a few barren protests. William Molyneux, however, in his celebrated treatise, which appeared in 1698 , amid the downfall of Irish commerce through English legislation, voiced the discontent of the period, the apprehension of what the jealousy of English commerce might ordain, and the reluctance to admit an authority in the English Parliament which had on previous occasions been repudiated in Ireland.* In his Case of Ireland's being bound by Acts of Parliament in England stated, he set up the claim of his country, based on strong historical arguments, for the absolute legislative independence which was eventually achieved in 1782 . The House of Commons at Westminster came to resolutions against this book, and directed that it should be burned by the common hangman. Miolyneux died in October, I698. Macaulay thinks that if he had lived a few years longer he would have been impeached. His treatise bore good fruit in the fostering of a public opinion in Ireland in opposition to the subordination of the Irish to the English Parlia-

* Ball's Legislative Systems, pp. 40-4 I. 
ment, and in stimulating intelligent criticism of the results produced by that subordination. When we remember the date of the publication of Molyneux's treatise-February, r698-and the date of the convening of the Irish Parliament, in the September of that year, we may, I think, confidently surmise that the legislation of the Irish Parliament in restraint of the woollen trade was, in its true inwardness, an effort to maintain the semblance of the power of that Parliament to legislate for Ireland, from the knowledge that, if the Bill were rejected, it would have been passed by the English Parliament, and that Ireland would be powerless to resist its operation. From the time of this prohibition of the woollen manufactures no Parliament was held in Ireland for five years, till $\times 703$. There is, moreover, evidence of the fear of public opinion at the effectswidespread poverty and destitution-produced by the deliberately devised ruin of the staple industry of the country. In I 701 pensions to the amount of $£_{1} 6,000$ were struck off.* In 1703,1705 , and 1707 the House of Commons resolved unanimously that " it would greatly conduce to the relief of the poor and the good of the Kingdom that the inhabitants thereof should use none other but the manufactures of the Kingdom in their apparel and the furniture of their houses, and, in the last of those sessions, the Members engaged their honours to each other that they would conform to the said resolution." $\uparrow$ The consequences of the prohibition are recorded in the Parliamentary Journals. In 1703 the House of Commons laid before Queen Anne a most affecting representation, containing, to use their own words, " a true state of our deplorable condition," protesting that no groundless discontent was the motive

* Lecky, II., p. 237.

$\dagger$ Hely-Hutchinson's Commercial Restraints, p. 143. 
for that application, but a deep sense of the evil state of their country, and of the further evils they have reason to fear will fall upon it if not timely prevented. They set forth the vast decay and loss of the country's trade, its being almost exhausted of coin, that they are hindered from earning their livelihoods, and from maintaining their own manufactures, that their poor have thereby become very numerous, that great numbers of Protestant families have been constrained to move out of the Kingdom, as well into Scotland as into the dominions of foreign Princes and States, and that their foreign trade and its concerns are under such restrictions and discouragements as to be thus become, in a measure, impracticable, although that Kingdom hath, by its blood and treasure, contributed to secure the plantation trade to the people of England. In a further address to Queen Anne, laid before the Duke of Ormonde, then Lord Lieutenant, by the House of Commons with its Speaker, they mention the distressed condition of that Kingdom, and more especially of the industrious Protestants, by the almost total loss of trade and decay of their manufactures, and to preserve their country from utter ruin, apply for liberty to export their linen manufactures to the Plantations. In a subsequent part of this session the Commons resolved that, by reason of the great decay of trade and discouragement of the manufactures of this Kingdom, many poor tradesmen were reduced to extreme want and beggary. The resolution was agreed to, nem. con., and the Speaker, Mr. Broderick, then Solicitor-General, afterwards Lord Chancellor, in his speech at the end of the session, informs the Lord Lieutenant that the representation of the Commons was, as to the matters contained in it, the 
unanimous voice and consent of a very full House, and that the soft and gentle terms used by the Commons in laying the distressed condition of the Kingdom before Her Majesty showed that their complaints proceeded not from querulousness, but from a necessity of seeking redress. He adds, it is to be hoped they may be allowed such a proportion of trade that they may recover from the great poverty they now lie under, and, in presenting the Bill of Supply, says the Commons have granted it " in time of extreme poverty" (see Hutchinson's Commercial Restraints of Ireland, pp. 15-17).

The tendency to throw land into pasture became so general after the peace in I $7 I_{5}$, owing to the destruction of industries, that the House of Commons, in 1716 , passed a resolution against covenants or leases forbidding tenants to break up or plough their land.* The position of the Irish Parliament towards the people at iarge made any efforts on their part to prevent the utter ruin of the country by restraints on its trade all but futile. Thus, in 1709 , a year in which the House of Commons macie some show of independence in rejecting a Money Bill because it had been altered in England, they presented the address to which I have referred to Queen Anne, urging strongly the fatal consequences of removing the outlawries of any persons who had been attainted in the rebellions either of $164 \mathrm{I}$ or 1688 , on the ground that any measure of clemency would shake the security of property. "The titles of more than half the estates," they said, "now belonging to the Protestants depend on the forfeitures of the two last rebellions, wherein the generality of the Irish were engaged " (Lecky's History of England in the Eightcenth Century, II., p. 286).

* Froude, I., p. 442. 
The absence of any approach to the spirit of nationality in the Irish Parliament at this time may be gauged from the fact that " in 1703 , four years before the Scotch Union was completed, both Houses of Parliament in Ireland concurred in a representation to Queen Anne in favour of a Legislative Union between England and Ireland, and, in 1707 , the Irish House of Commons, while congratulating the Queen on the consummation of the Scotch measure, expressed a hope that God might put it into her heart to add greater strength and lustre to her Crown by a yet more comprehensive Union." " The spirit," writes Lecky, " of commercial monopoly triumphed. The petition of the Irish Parliament was treated with contempt, and a long period of commercial restrictions and penal laws and complete Parliamentary servitude ensued" (Lecky's History of England in the Eighteenth Century, VIII., pp. 268-269). There were, however, occasional attempts at the assertion, not, indeed, of independence, but of some slight control over the Executive. In 1709, as I have mentioned, a Money Bill was rejected because it had been altered in England, and, in the last days of Queen Anne, the vehement Whig policy of the Irish House of Commons, who feared alterations in the Land Acts of Settlement and Explanation, and, perhaps, the repeal of these enactments, so seriously impeded the Tory, if not Jacobite, policy of the Government, that Sir Constantine Phipps, an English lawyer, who was then Irish Lord Chancellor, appears to have contemplated the possibility of reducing the expenditure of the country to the limits of the hereditary revenue, whose sources have been explained, and governing without a Parliament.* The increase of the army, the erection of

* Lecky's History of England in the Eighteenth Century, II., p. 418. 
barracks, and other expenses resulting from the Revolution, had made the hereditary revenue insufficient, and it became necessary to ask for fresh supplies. "This insufficiency of the hereditary revenue laid the foundations of the power of the Parliament, and that power was increased when the Government found it necessary, in 1715 , to borrow $£ 50,000$ for the purpose of taking military measures to secure the new dynasty. The National Debt, which before this time had been only $£_{16,000}$, became now a considerable element in the national finances. It grew in the next fifteen years to rather more than $£ 330,000$, and a series of new duties was imposed by Parliament for the purpose of paying the interest and principal."*

The helplessness, however, of the Irish Parliament is thus demonstrated by Hely-Hutchinson. He states that in $172 \mathrm{I}$, during a period of great distress, the Speech from the Throne and the Addresses to the King and Lord Lieutenant declare in the strongest terms the great decay of trade and the very low and impoverished state to which the country was reduced. "But," he says, "it is a melancholy proof of the desponding state of this kingdom that no law whatever was then proposed for encouraging trade or manufactures, or, to follow the words of the Address, for reviving trade, or making us a flourishing people, unless that for amending laws as to butter and tallow casks deserves to be so called And why? Because it was well understood by both Houses of Parliament that they had no power to remove those restraints which prohibited trade and discouraged manufactures, and that any application for that purpose would at that time have

\footnotetext{
* Lecky's History of England in the Eighteenth Century, II., p. 224.
} 
only offended the people on one side of the Channel without bringing any relief to those on the other" (Commercial Restraints, pp. 25-26).

And then, as so often happens when all things seem invested with impenetrable gloom and hopelessness, a light came unexpectedly to illumine the darkness. In I720-the year after the Parliament of England had passed the Statute to which I have referred, asserting in the most express terms the subjection of the Irish Parliament, and denying all appellate jurisdiction to the Irish House of Lords - the Government felt themselves bound to endeavour to suppress a powerful appeal made, not by Parliament or to Parliament, but to the people at large. The House of Commons had passed, again and again, resolutions urging the exclusive use of Irish manufactures, but the tract of Swift, in 1720 , with the same object in view, exercised a more powerful influence than any resolution of the House of Commons. The institution of proceedings for the prosecution of the printer of this tract was, in itself, an acknowledgment of the impression it had produced on the public mind. The failure of that prosecution may be regarded as the first popular triumph over the system of English misgovernment and oppression in Ireland, and that triumph came, not from within the Parliament, but from without. The battle was fought and won, not in the Irish House of Commons, but in a Law Court, where a jury proved themselves the champions of the liberty of the subject. " Nine times the jury desired to return a verdict of not guilty, and nine times they were sent back by the presiding Judge, Chief Justice Whitshed, who placed his hand on his breast and declared his belief that the pamphlet was written in the interests of the Pretender "- 
a statement calculated to have a prevailing weight with men who believed the advent of the Pretender would mean their undoing by the repeal of the Act of Settlement. He prolonged the disgraceful scene for eleven hours, till the jury brought in a special verdict, leaving the matter to the Judge himself. The unpopularity of the prosecution was so great that the Government did not venture to proceed further. A second trial was contemplated, but more prudent counsels prevailed, and a nolle prosequi was entered.*

The rise of the movement which culminated in Irish Parliamentary Independence, established in 1782, may be dated from 1724 . In 1722 a Memorial was presented to the Lords of the Treasury, complaining of the base quality of the copper coinage then in circulation, and in that year it was determined to issue a new coinage. The privilege of supplying that coinage was given by royal prerogative to the Countess of Kendal, one of the mistresses of George I., who had an Irish pension of the annual value of $£ 2,500$, and whose daughter, Lady Walsingham, had another Irish pension of $f_{1}, 500$. The Duchess of Kendal sold the patent thus obtained to one William Wood, an English ironmonger. By the terms of the patent, one pound avoirdupois of copper was to be coined into halfpence and farthings to the nominal value of $25.6 \mathrm{~d}$., while it was acknowledged that the market price of this quantity of uncoined copper was only $12 d$. or $13 d$. In order that the pronits should be very large, a sum of no less than $f_{108,000}$ was to be coined. In England the copper coinage served only for the convenience of change, and its intrinsic value was a matter of indifference. In Ireland the whole current coin was believed to be not more than $£ 400,000$,

* I.ecky's History of England in the Eighteenth Century, II., p. 420.

Froude's English in Iveland, I., pp. 561-562. 
and the proposal to coin in copper more than a fourth part of that sum made the question of value vitally important, for the new coins would necessarily enter into all large payments, gradually displacing gold and silver, which, it was found, would all, or nearly all, pass to England in the shape of rents, leaving but a debased copper coinage at home. Both Houses of Parliament, and most of the Corporations, voted addresses against the coinage, and there was a general resolution to refuse it, although the patent obliged no one who was unwilling to receive the coin, and the reduction of the sum to be coined from $\ell_{1} 08,000$ to $f_{4}, 000$ by no means assuaged the intense indignation at its appearance, which was increased by the boast of Wood, that he would ram the coin down the throats of the people. When the agitation was at its highest, Swift, in 1724 , under the assumed name of M. B. Drapier, addressed a series of letters to the people of Ireland, attacking Wood and his patent with all his powers of ridicule and invective, and demanding the annulling of the patent. The national spirit was at last aroused, and it was finally irresistibie. In the fourth of the Drapier's letters, Swift, with unerring tact, changed the controversy from Wood's halfpence into an examination conducted with remorseless bitterness of the manner in which the Government of Ireland was carried on in regard to the social and political condition, and, in the plainest terms, claimed for the Irish Legislature the right of selfgovernment.*

The creed of the Irish Patriot Party is enunciated in the following words of Swift :-

"Those," he writes, "who come over hither to us

* Ieciry's History of England in the Eighteenth Century, II., pp. 420-424. 
from England, and some weak people among ourselves, whenever in discourse we make mention of liberty and progress, shake their heads and tell us that Ireland is a depending Kingdom, as if they would seem by this phrase to intend that the people of Ireland is in some state of slavery or dependence different from those of England, whereas a depending Kingdom is a modern term of art unknown, as I have heard, in all ancient civilians and writers upon governments, and Ireland is, on the contrary, called in some Statutes an Imperial Crown as held only from God, which is as high a style as any Kingdom is capable of receiving. Therefore, by this expression-a depending Kingdom-there is no more understood than that by a Statute made here in the thirty-third year of Henry VIII., the King and his successors are to be Kings Imperial of this Realm, as united and knit to the Imperial Crown of England. I have looked over all the Irish and English Statutes without finding any law which makes Ireland depend on England any more than England doth upon Ireland. We have, indeed, obliged ourselves to have the same King with them, and, consequently, they are obliged to have the same King with us. For the law was made by our own Parliament, and our ancestors were not then such fools (whatever they were in the preceding reign) to bring themselves under, I know not what dependence, which is now talked of without any ground of law, reason, or common sense. Let whoever think otherwise, I, M. B. Drapier, desire to be excepted. For I declare next, under God, I depend only on the King, my sovereign, and on the laws of my own country. And I am so far from depending on the people of England, that if they should ever rebel against my 
Sovereign (which, God forbid), I would be ready at the first conmand from His Majesty to take arms against them, as some of my countrymen did against theirs at Preston. And, if such a rebellion should prove so successful as to fix the Pretender on the throne of England, I would venture to transgress that Statute so far as to lose every drop of my blood to hinder him from being King of Ireland. It is true, indeed, that within the memory of man the Parliaments of England have sometimes assumed the power of binding this kingdom by laws enacted there, wherein they were at first openly opposed (as far as truth, reason, and justice are capable of opposing) by the famous Mr. Molyneux, an English gentleman born here, as well as by several of the greatest patriots and best Whigs in England, but the law and torrent of power prevailed. Indeed, the arguments on both sides were invincible. For, in reason, all government without the consent of the governed is the very definition of slavery. But, in fact, eleven men well armed will certainly subdue one single man in his shirt."

Swift makes no secret of the motive which urged him to enunciate these constitutional principles. "The remedy," he writes, " is in your own hands, and, therefore, I have digressed a little in order to refresh and continue that spirit so reasonably raised among you, and to let you see that, by the laws of God, of Nature, and of your own country, you are, and ought to be, as free a people as your brethren in England."

The chord thus struck " vibrated through every class in Ireland," more especially as the question was unconnected with creed or party. The Government, in alarm, offered a reward of $£ 300$ for the apprehension of the 
writer of the letter, but, although he was generally known, no evidence could be obtained. A prosecution was instituted against the printer, but the Grand Jury, in spite of the strenuous exertions of Chief Justice Whitshed, ignored the bill, and, not content with this, presented all who consented to receive the money.* The Government bent before the storm. The coins were withdrawn from circulation, the patent was revoked, and Wood received as compensation a pension of $£ 3,000$ a year, payable for eight years. $\dagger$ When the question of Wood's halfpence was decided, the larger controversy of the subordination of the Irish to the English Parliament was suspended for a season, to be revived at a later and more opportune period. To Swift, however, belongs the credit of having sown the seed which afterwards matured and yielded fruit in due season. The best tribute to Swift's work in this episode, which occupies so conspicuous a place in Irish history, is that given by Mr. Whiteside, an eminent Conservative lawyer, in the middle of the last century, who, having represented Dublin University in the Imperial Parliament, where he achieved a high reputation as a Conservative leader, was afterwards Lord Chief Justice of Ireland. "Had there been," he writes, " a few in the Irish Parliament possessed of the originality, energy, honesty, and capacity of Swift, the management of political affairs and the true interests of the country would have speedily been improved instead of being shamefully neglected. Swift created a public opinion; Swift inspired hope, courage, and a spirit of justifiable resistance in the people; Swift taught Irishmen they had a country to love, to raise,

\footnotetext{
* Lecky's History of England in the Eighteenth Century, pp. 420425 .

Froude's English in Ireland, I., pp. 582-608.
} 
to cherish. No man who recalls the affectionate respect paid by his countrymen to Swift while he lived-to his memory when dead-can impute political ingratitude to be amongst the vices of the Irish people " (Whiteside's Irish Parliament, p. 89).

"This contest," writes Mr. Lecky, "deserves to be placed in the foremost ranks in the annals of the Irish race. There is no more momentous epoch in the history of a nation than that in which the voice of a people has first spoken, and spoken with success. It marks the transition from an age of semi-barbarism to an age of civilisation, from the government of force to the government of opinion. Before this time rebellion was the natural issue of every patriotic effort in Ireland; since then rebellion has been an anachronism and a mistake. The age of Desmond and O'Neill had passed; the age of Grattan and O'Connell had begun."*

"Swift," writes Mr. Redmond, " now became the idol and the leader of the Irish people. He taught them. their first lessons in self-reliance. He led them to victory when oppression had well nigh broken their spirit, and when the exile of all their leaders had robbed them of hope, he held up before their eyes the possibilitysoon afterwards in part to be realised-of the fusion of the two sections into one nation." $†$

The great constitutional victory in the matter of Wood's halfpence, impressed on the English Government the wisdom of provoking no controversy which might have a tendency to unite all classes of the Irish people by a community of interest in determined opposition to misrule. For the next few years the contests between

* Leaders of Public Opinion, p. 49.

$\dagger$ Irish Protestants and Home Rule, p. 10. 
the Country Party and the Government were confined to matters of finance. Thus, in 1731, during the first Administration of the Duke of Dorset, a new financial question arose about a fund which had been provided for paying the principal and interest of the National Debt. " The Court Party, ever desirous of withdrawing the control of the finances from Parliament, desired that this sum should be granted to His Majesty, his heirs, and successors for ever, redeemable by Parliament. The Opposition insisted that it should be granted in the usual constitutional fashion from session to session. The Court Party proposed, as a compromise, to vest it in the Crown for twenty-one years, and this proposition was put to the vote. The numbers were at first equal, but, at the last moment, Colonel Tottenham, the Member for New Ross, who had 1idden over in haste to be piesent at the division, appeared in boots and in a riding attire splashed with mud in the midst of an assembly which then always met in full dress, and his vote turned the balance against the Government." Again, in 1749 , " under the Administration of Lord Harrington, there had been a very unusual gleam of prosperity ; the Peace of Aix-laChapelle had been followed by a sudden increase of Irish commerce ; a surplus of over $£_{200,000}$ appeared in the Exchequer, and it was resolved to appropriate $f_{0}, 120 ; 000$ towards the payment of the National Debt. Heads of a Bill for this purpose were sent over to England, but the English authorities maintained that the surplus belonged to the Crown, and that the Irish Parliament could not even discuss its disposition without the previous consent of the King. To establish this principle, the Duke of Devonshire opened the Session of $175^{1}$ by a

\footnotetext{
* Lecky's History of England in the Eighteenth Century, II., p. 428.
} 
speech signifying the royal consent to the appropriation of a portion of the surplus to the liquidation of the National Debt. The House, on the other hand, passed such a Bill, but carefully omitted to take any notice of the consent. The Bill, when it was carried in Ireland, was sent over to England, and returned with an alteration in the preamble signifying that the royal consent had been given, thus establishing the principle. The House succumbed, and passed the Bill in its altered form. In 1753 the contest was renewed. The speech from the Throne again announced the consent of the Sovereign to the appropriation of the new surplus towards the payment of the National Debt. The opposition, however, was now stronger. The reply to the Address took no notice of the consent of the Sovereign. The Bill was sent over as in the previous Session, omitting to notice it, and this time, after an excited debate, the House, by a majority of five, rejected the Bill on account of the alteration. The Government dealt with the subject with a very high hand. All the servants of the Crown who voted with the majority were dismissed, and a portion of the surplus was applied by royal authority to the payment of the debt."* This question, which regarded the right of the House of Commons to superintend and control the expenditure of public money, was quickly perceived to be one of vital magnitude to the liberty and prosperity of the country. A serious Parliamentary organisation was at last organised as the result of these proceedings, and their effect on the public was evidenced by the extraordinary interest taken in Parliamentary matters by the formation of patriotic societies, and by petitions, addresses, and resolutions supporting the Speaker. The conduct of the

* Lecky, II., pp. 43I-432. 
Government in dealing with the surplus was such that the Opposition resolved that no further surplus should exist, and began, accordingly, to appropriate public money largely to local improvements.

The struggle in reference to the disposition of the surplus communicated life and heat to the Irish House of Commons. So rapid was the importance it gave to that assembly, that a borough sold in 1754 for three times as much as in $175^{\circ}$. " Supposing," writes Hardy, the biographer of Lord Charlemont, "the speculation a corrupt one, it proves the rising consequence of the popular branch of the legislature when such a speculation could be made at all. There was much private corruption, but there was also a lofty public principle and liberty altogether predominant and progressive" (Hardy's Life of Charlemont, I., pp. $8 \mathrm{I}-82$ ).

We have seen that, on the destruction of the Irish woollen manufacture, there were resolutions of the Irish Parliament in favour of a Legislative Union passed, no doubt, in the hope that such a measure would have the effect of removing the restraints on trade, and securing the maintenance of the system whereby, under the Act of Settlement, the land of Ireland was possessed by its present holders. The events of half a century, however, had inspired all classes of the community with a national sentiment, and with a love for the Irish resident Parliament, from which, notwithstanding all its imperfections, great things were hoped. Swift had taught the lesson that the voice of a united people could not be silenced, and that the power which that voice called into being was at the last irresistible. When, in 1759 , a rumour that a Union, which was prayed for in the first decade of the century, was in contemplation, the 
people were lashed into uncontrollable fury, and a riot broke out in Dublin, which was the fiercest ever known in the metropolis. The mob burst into Parliament House, seated an old woman on the Throne in the House of Lords, placed a pipe in her mouth, and insisted on her smoking. They searched for the Journals which they desired to burn, stopped the carriages and killed the horses of the Members. They insulted the Lord Chancellor and some of the Bishops, erected a gallows on which they intended to hang Rigby, the Chief Secretary, who had been made Master of the Rolls, and to whom they attributed the machination of a scheme for the destruction of the Irish Parliament, and compelled all who fell into their hands to swear that they would oppose the measure (Lecky, II., pp. 435-436 ; Froude, I., pp. 698-704). 
VIII.

\section{THE RISE AND PROGRESS OF PARLIA- MENTARY OPPOSITION IN IRELAND.}

From the contest with reference to the disposal of the surplus in 1753 , we may date the rise of a Parliamentary Opposition in Ireland. It must, however, be borne in mind that the Country Party, as it was termed, to distinguish it from the Court Pary, was, in its personnel, as changing as the colours in a kaleidoscope. An eminent politician in fierce opposition might be found in the very same session, or in the next session, a supporter through thick and thin of the Government. The Opposition, whose criticism of the Government and of Government measures was speciously declared to be for the public good, had not infrequently its true motive in desire for place or power or title or pension, in disappointment at the failure in attaining such objects, and in the exercise of unpleasant and sometimes dangerous tactics to acquire Parliamentary importance, which it would be well worthy of the pains of the Government to conciliate with the desired reward. "The work of patriotism," writes Lord Charlemont, who was for upwards of forty years a prominent figure in Irish public life, "is often assumed to disguise self-interest 
and ambition, and the paths of violent opposition are frequently trod as the nearest and surest road to office and emolument. These frequent apostasies have been used by the corrupt as an inexhaustible source of ridicule, and even of argument, against true patriotism ; the same species of false wit and false reasoning have been repeatedly urged against religion itself. But such flowery prattle does not merit a serious confutation. As well might we say, because there are many hypocrites, men ought not to be moral or religious " (Hardy's Life of Charlemont, I., p. 94).

Amid the corrupt bargains for peerages, pensions, sinecure offices, promotions in the Church and the Law, and management of the Houses of Parliament by powerful owners of nomination boroughs, some of whom in the absence of the Lord Lieutenant, who only resided in Ireland in a Parliamentary Session, which was biennial, were Lords Justices, and known as "Undertakers," the controversies in the House of Commons reached the Commons at large. whose hearts and minds had been well prepared to appreciate the merits and demerits of a faction by the formation of that educated public opinion to which the writings of Molyneux, of Berkeley, and of Swift so powerfully contributed. The system, however, of government by "Undertakers," or, in other words, by a few great personages who possessed an extraordinary Parliamentary influence, and who undertook to carry the King's business through Parliament on condition of obtaining a large share of the disposal of patronage, obtained.* That system, however, although not controlled, was restrained and arrested by an active press, and by an Opposition who aspired "to make the Irish Parliament in Irish affairs

* Lecky, II., p. 435. See also ibid., p. 453, and Appendix. VII. 
what the English Parliament was in English affairs, and to secure for the Irish Protestants all those constitutional rights which the Revolution of 1688 had established in England, and of which the English people were so justly proud."* The first forty years of the reign of George III., from 1760 till I800, was the period of the great Parliamentary history of Ireland which was terminated by the Union. The Parliament of Ireland lasted an entire reign, unless dissolved by the exercise of the prerogative, and the Irish Parliament of George II., which was dissolved by his death, had sat for thirtythree years, the entire period of his reign. A whole generation had grown up which had not witnessed a general election. Flood, who entered the House of Commons in 1759, at the age of seven and twenty, sat in a Parliament which had been convened some years before he was born. The persons in charge of the Irish Administration were not inobservant of the signs of the times, and of an element of opposition to anomalies, abuses, and denials of constitutional liberties, which would certainly make its power felt in the new House of Commons and on Parliamentary candidates. On the eve of the election which took place on the accession of George III., public meetings were held, and stringent tests imposed upon candidates, chiefly in reference to the securing of an Act for the shortening of the duration of Parliament, and to the abatement of the scandals of the Pension Lists. $†$

The Lords Justices and the Irish Privy Council, on the accession of George III., strongly contended that a Money Bill should not be certified from the Privy Council as the cause for the summoning of a Parliament,

* Lecky's History of England in the Eighteenth Century, IV., p. 352.

$\dagger$ Lecky, IV., pp. 359-360. 
and that to the Irish House of Commons should be left the privilege of originating Money Bills themselves. A Money Bill, it was said, is, by the theory of the Constitution, a free grant made by the Commons to the Sovereign, and it was, therefore, plainly unconstitutional that it should take its rise in a body such as the Privy Council, which is neither virtually nor professedly representative. They stated, in a very able and elaborate representation to the Lord Lieutenant, the Duke of Bedford, that such a Bill would be surely rejected in Parliament, and that, in the existing condition of men's minds, it would create a ferment at the beginning of a new reign which would speedily be diffused throughout the whole Kingdom. A motto was prefixed to this document, being the words spoken by Strafford before he had joined the Royalist side: "This hath not been done by the King, but by the projectors who have extended his prerogative beyond its just bounds. They have introduced a Privy Council ravishing at once the spheres of all ancient government." The English Privy Council, however, refused to depart from the former precedents. After considerable discussion, the Lords Justices consented to certify and support the Money Bill, which was carried without difficulty through Parliament.* William Gerard Hamilton, so well known in England as " Single-speech " Hamilton, was Chief Secretary to the Lord Lieutenant, and accordingly defended, in the Irish House of Commors, the Money Bill procedure. $\dagger$ His argument is very able and instructive, as explaining the difference and contrast between British legislation and Irish legislation under the provisions of Poynings' Law : "As to the analogy between this and the British House of Commons, every

* Lecky, IV., p. 359. Whiteside's Irish Parliaments, p. I I 2

+ Appendix VIII. 
argument must be incomplete which means to assimilate things which are in their very form and origin-in their very first concoction-not only different, but opposite. The two Constitutions were once, indeed, upon the same model. The plan of Poynings' Act was to remove the Irish Constitution from the ground on which it stood, to change the model of it, and to make it not only different, but, in some respects, the very reverse of the House of Commons." *

At the General Election to the Irish Parliament, which took place in October, $176 \mathrm{I}$, pledges as to Parliamentary action were enforced for the first time on candidates-a course which was followed in England some years later, in 1769 . The Irish House of Commons in this Parliament had a new experience-the exercise of pressure from without. The limitation of the duration of Parliament to a reasonable length was, as I have said, a cardinal object of policy with the reformers. The creation of a strong public opinion in favour of this measure was due to influence which was at first brought to bear upon Parliament from without. That influence was acquired by Charles Lucas, a Presbyterian apothecary, without means or any adventitious advantages, a cripple in ill-health, but a man of high principles, absolute fearlessness, indomitable energy, and superabounding enthusiasm. In 1743 Lucas came into public notice in an attempt to reform the Dublin Corporation, of which he was a member, then labouring under gross mismanagement. He detected and exposed serious encroachments that had been made in the electoral rights of the Dublin citizens, and, by an easy transition, applying his attention to higher matters of

\footnotetext{
* Whiteside's Irish Parliament, p. I I 3.
} 
public interest, became the most popular writer in the Dublin Press, advocating the principles of Molyneux and Swift, and urging especially the necessity of shortening the duration of Parliament.* In 1747 he commenced the publication of the Citizen's Fournal in Dublin in the viceroyalty of the Earl of Harrington, by whom, at first, he had been favourably received. He dedicated the first number of the paper, a weekly organ, in which the abuses of the Irish system of government and of Irish society were denounced, to the King. Lucas then appeared at a viceregal levée, intending to ask Lord Harrington if he had transmitted the dedication to the King. The Lord Lieutenant sent an officer to desire him to leave the reception room. A full account of the incident was published in the next number. Lucas became, like Swift, the idol of the people, and in a Parliamentary vacancy occurring for the City of Dublin, Lucas came forward as a candidate-his election being regarded as an absolute certainty. "The incendiary," wrote the Lord Lieutenant, " had gained so many converts that it was absolutely necessary to put a stop to his proceedings."

Before the writ for the city election could be issued, at the opening of the Parliamentary Session, Lord Harrington denounced him in his speech from the Throne. On the second day of the Session of 1749 complaint was made to the House of Commons of certain seditious writings of Dr. Lucas, which were, after some fruitless opposition, voted highly criminal. Lucas, when he had been induced before the starting of the Citizen's fournal to have an interview with the Lord Lieutenant, was so cordially listened to that he left with the Lord Lieutenant, for his own justification,

*Lecky, II., pp. 429-+3o.

† Froude, I., pp. 677-680. 
some pamphlets which had been much censured by the Government dependents. When he was summoned to the Bar of the House of Commons, he was merely asked whether he was the author of such-and-such papers. It would have been scarcely possible to prove the authorship, the printer was not to be found, and no evidence was forthcoming, when Mr. Weston, the Chief Secretary of the Lord Lieutenant, who was a Member of the House of Commons, produced, with cunning treachery, the very papers which Lucas had left at the Castle for the perusal of the Lord Lieutenant. Lucas withdrew to England, and, to prevent his return to Ireland, he was voted by Parliament an enemy to his country, and thus compelled for some years to go into exile. Mr. La Touche, who was returned for the vacant Dublin seat, was unseated on petition, on the sole accusation of having been joined to and influenced by Lucas, and a supporter of the Government placed in his stead. " A more infamous proceeding," writes Hardy, " never disgraced any House of Commons " (Life of Charlemont, I., pp. 299-303).

Lucas, who at first fled to the Isle of Man, pursued his profession in London, and wrote an Essay on Waters, which was reviewed by Dr. Johnson, who thus recommended him to the notice of the British public: "The Irish Ministers drove him from his native country by a Proclamation, in which they charged him with crimes which they never intended to be called to the proof, and oppressed him by methods equally irresistible by guilt or innocence. Let the man thus driven into exile for having been the friend of his country be received in every other place as a confessor of liberty, and let the tools of power be taught in time that they may 
rob, but cannot impoverish." At length he was enabled, by the interposition of some powerful interest, to return to Ireland, where he was, in 1761 , elected a Member of the House of Commons for the City of Dublin-a pesition from which he had been twelve years previously debarred. He sat in the Irish House of Commons till his death in 1771 .

I have dwelt at such length on the career of Lucas, whose memory is fast sinking into oblivion, as the head of a political agitation organised and directed outside the House of Commons, which prevailed to place the Octennial Bill, which was the nidus from which all the subsequent popular measures sprang, on the Statute Book. As in the case of many other men, whose influence in the Press, on the platforms, in the management of party, has been great, Lucas, as a Parliamentarian, was ineffective. $\mathrm{He}$ is thus described by the biographer of Lord Chariemont, who evidently reproduced the estimate formed of Lucas by Lord Charlemont, who held him in great personal esteem and affection: "As a politician, Lucas was, as Duc de Beaufort was called during the time of the Fronde at Paris, un roi des halles -a sovereign of the Corporations. In the House of Commons his importance was withered, and, comparatively, shrunk to nothing . . . . Lucas had, in truth, little or no knowledge as a leader in Parliament, and his efforts there were, too often, directed against men whose perfect disregard of him left them at full liberty to pursue their argument as if nothing had disturbed them. Self-command, whether constitutional or arising from occasional contempt, is a most potent auxiliary. His opponents were sometimes, indeed, rendered indignant, but, whether calm or angry, the 
battle always left him worse than before. Yet, with al! his precipitancy, and too frequent want of knowledge, he annexed a species of dignity to himself in the House of Commons which was not without its effect. His infirmities-for he was always carried into and out of the House-being so enfeebled by the gout that he could scarcely stand for a moment, the gravity and uncommon neatness of his dress, his gray and venerable locks, blending with a pale but interesting countenance, in which an air of beauty was still visible, altogether excited attention, and I never saw a stranger come into the House without asking who he was. The surest proof of his being in some way or other formidable to Ministers was the constant abuse of him in their papers. . . . He had certainly talents, but talents unaided by cultivation. Originality is merit. He raised his voice when all around was desolation and silence. He began with a Corporation, and he ended with a Kingdom, for some of the topics he suggested, such as the Octennial Bill, were of vital magnitude to Ireland " (Hardy's Life of Charlemont, I., pp. 302-305).

The various methods by which the legislation of the Irish Parliament was liable, before 1782 , to be destroyed, mutilated, and spoiled by crippling amendments or postponements, which I have already sketched, cannot be better illustrated than in their application to the proposal for the shortening of the duration of Parliament, which, although immediately brought forward in the Parliament which met in October, 1761 , failed to reach the Statute Book in any form, despite the pledges given to vote in its favour for seven years, till an Act was passed which fixed eight years as the utmost period of life for an Irish Parliament. The Heads of a Bill for 
a Septennial Parliament were brought forward on the very first day on which the new Parliament sat, on 22nd October, 1761. If the Irish House of Commons, who, in their hearts, hated this measure, which they were pledged to support, could have been assured that it would be rejected in England, they would gladly have passed it. They united it with a property qualification for Members of Parliament- $£ 600$ a year in real estate for a county seat, and $£ 300$ for a borough seat-hoping that, by this addition, the Bill would be less acceptable to the other branches of the legislature. The English Property Qualification Act, passed in the reign of Queen Anne, never became law in Ireland until after the passing of the Act of Union. A measure similar to the English Act had frequently been passed in the Irish House of Commons, but it was invariably rejected by the House of Lords, owing to the fact that the proprietors in that Assembly of rotten boroughs in the House of Commons desired to have the power of putting into these boroughs penniless men, who would naturally be more dependent on their patrons, more amenable to their wishes in voting in the direction dictated by the interests of the " owners " of the boroughs, and in accordance with the bargains for Parliamentary support between them and the Government. When, on the 9th December, it was moved that the Lord Lieutenant would be pleased to recommend the measure in the most effectual way to His Majesty, the motion was negatived by a large majority in the House of Commons, who also refused to present it in a body to the Lord Lieutenant. The public indignation provoked by these proceedings, which demonstrated the insincerity of the House of Commons, elicited the 
following undignified resolution of that body on 26 th April, I762: "Resolved-That the suggestions confidently propagated that the Heads of a Bill for limiting the duration of Parliament, if returned from England, would have been rejected by this House, are without foundation." The Heads of the Bill were eventually transmitted to England by the Irish Privy Council, which assented to this course after a decision carried by a majority of one. The Heads of the Bill were not returned from England. Lord Halifax was succeeded in the Viceroyalty by the Earl of Northumberland, when the same disingenuous and discreditable tactics obtained. Leave was given to bring in the measure on $15^{\text {th }}$ October, 1763 ; it was not presented till the $14^{\text {th }}$ December, nor reported till the middle of February." The House of Commons, with the object of making a specious atonement for their conduct in the Viceroyalty of Lord Halifax, assumed an attitude of seriousness, and addressed the King through the Lord Lieutenant, asking him to assent to it. Northumberland answered that he had received information of the most authentic nature that the Bill for limiting the duration of Parliament would not be returned this Session. For the present, accordingly, the English Ministers took upon themselves the responsibility of rejecting it, much to the secret gratification of the Irish House of Commons and the Irish Privy Council.

This policy of deception and prevarication increased the determination of the Irish people not to permit themselves to be fooled by such manœuvres. The High Sheriffs, and more than 800 of the Protestant merchants and traders of Dublin, signed a paper of instructions to their Members enjoining them to vote

\footnotetext{
* Hardy's Charlemont, I., pp. 250-25I.
} 
for no Money Bill of a longer duration than three months until a Septennial Bill had become law. "Is was a serious thing," writes Mr. Lecky, "to resist the strongest and most persistent wish of the electoral body in Ireland, and the attitude of Parliament on the question already showed that, in spite of all the defects in the Constitution, the popular voice had a real, if not a controlling, influence within its ranks " (Lecky's History of England in the Eighteenth Century, IV., pp. 367-370; Froude's English in Ireland, II., pp. 7-11).

The ultimate triumph of this measure is thus related by Mir. Hardy: "Once more the people petitioned, and once more the House of Commons sent the Bill to their good friends, the Privy Council, enjoying in public the applause of the nation for having passed it, and in secret the notable triumph that it would be soon destroyed. But here matters assumed a different aspect; the Privy Council began to feel that this scene of deception had been long enough played by the Commons, and being, with some reason, very much out of humour that the plaudits of the nation should be bestowed on its representatives, whilst His Majesty's Privy Council, by the artifice of some leaders, was rendered odious to the country, resolved to drop the curtain at once, and certified the Bill to the English Privy Council, satisfied that it would encounter a much more chilling reception there than it had met with even from themselves. The aspect of affairs was again changed. The Irish Privy Council had disappointed the Commons, and the English Cabinet now resolved to disappoint and punish both. Enraged with the House of Commons for its dissimulation, with the aristocracy for not crushing the Bill at once, and, amid 
all this confusion and resentment, not a little elated to have it in their power completely to humiliate that aristocracy, which, in the true spirit of useful obsequious servitude, not only galled the people, but sometimes mortified and controlled the English Cabinet, itself afraid of popular commotions in Ireland, feeling as English gentlemen that the Irish public was in the right, as statesmen that it would be wise to relinquish at once what in fact could be but little longer tolerable, they sacrificed political leaders, Privy Councillors, and Parliament to their fears, their hatred, their adoption of a new policy, and though last, not the least motive, it is to be hoped, their just sense of the English Constitution."* They returned the Bill changed from a Septennial to an Octennial one. The charge frequently made, that this change was a manœuvre intended to induce Parliament to reject it, is unfounded. The provision was inserted in order to suit the special circumstances of Ireland, when Parliament only sat every second year, and also to prevent the inconvenience which would arise if general elections in England and Ireland were spontaneous (Lecky's History of England in the Eighteenth Century, IV., p. 381). The Bill was once more, according to the mode of passing Bills in those days, to appear before Parliament. The Parliament House was surrounded by many thousands of men who compelled the Members, as they entered, to promise that they would vote for the Bill, and all over the country the excitement was such that it would have been madness to have resisted. The Bill quickly passed through both Houses, while the House of Lords consented to its passage through all its stages on the same day, and

* Hardy's Life of Charlemont, I., pp. 252-253. 
passed a resolution declaring that this course, which is not to be drawn into a precedent, was adopted as a distinguishing mark of the approbation of the House of the Bill. The carriage of the Lord Lieutenant was drawn by the crowd from the Castle to Parliament, when he went to pronounce the royal assent to a Bill which may be said, in the words of Lord Charlemont, to have first unlocked the political energies of Ireland, and which, in the opinion of Mr. Lecky, laid the foundation of Irish Parliamentary influence and independence.*

Dr. Ball thus sums up the effects of the Octennial Act : "The Act unquestionably effected great changes in the character of the Irish House of Commons; previously its Members had practically only one immediate source of insecurity in their seats to fearthe Crown might dissolve Parliament. Their interest, therefore, led them to support the King's Ministers, since this was the way to avert a dissolution. Independence could be expressed in debate, but, in voting, the Government were not to be placed in a minority, since defeat would lead to a general election. Now, instead of a possible undisturbed tenure for the reign, it might be of a youthful sovereign, a representative of the Commons had the certainty, in the case of a county or city, of meeting his constituents, or, in the case of a small borough, the patron who nominated him, at the latest, eight years after his return. The electors, not the Crown, became the task-master to be obeyed. And, as a consequence, if a policy were popular outside Parliament, it soon came to be popular within it, at least so far as the votes of Members were concerned.

Contemporaneously with the passing of the Octennial Act, Parliament was dissolved, and a new

$$
\text { * Lecky, IV., p. } 382 .
$$


House of Commons was elected. The infiuences which the Act brought into operation were apparent in the character and subsequently in the conduct of its Members. From this period may be traced an increased manifestation of the sentiments popular among the people generally. At the same time, more zeal for the public service, greater political knowledge, and improved capacity in the management and discussion of affairs became perceptible" (Ball's Irish Legislative Systems, pp. 88-89). 
IX.

'THE FIGHT FOR LIBERTY AGAINST CORRUPTION.

Trie Parliament of Ireland, by which the Octennial Act was passed, was dissolved on May 28th, 1768 . The new Parliament, owing to the fact that Parliaments in Ireland up to this period were convened, not annually, but biennially, did not meet till October 17 th, 1769 , although the General Election had taken place long previously. The impulse given by the Octennial Act to the movement in favour of popular rights and liberties may render it of interest to sketch what were the aims at this period of the "Country" or, in other words, of the Patriot Party in and out of Parliament. I have outlined the defects of the Irish Constitution. The objects of the Patriot Party were to obtain for Irish Protestants the laws which were regarded by Englishmen as the safeguards of their liberty. Their object, likewise, was to abolish the scandals of the Irish pension list, and the system under which the great Irish offices of State were bestowed as sinecures on Englishmen nonresident in Ireland. The constitution and powers of the Irish Parliament being such as I have attempted to describe them, and Members of that Parliament being themselves in the very necessity of things in many cases amenable to Government influence, and exercised in the securing of titles, places, pensions for themselves or their protégés, the difficulty of the struggle for the establishment of a free Constitution may be appreciated, 
more especially when the Patriot Party were far from unanimous on the subject of the admission of the Roman Catholics, who were the overwhelming majority of the population, into a participation of the liberties for which they themselves were struggling. Again, the absence of the Lord Lieutenant, before the Viceroyalty of Lord Townshend, from the country, when Parliament was not in session, placed the administration in the hands of the Lords Justices, a Lord Primate-a nobleman with powerful interest in election to nomination boroughs-and a Speaker of the House of Commons, who, sometimes themselves, sometimes with the assistance of others, managed to maintain a Ministerial, as opposed to a Patriot Party, for the smooth working of the Government machine, and for the bringing of the Parliament, when it met, into harmonious relations, not with the people, but with the Castle. The very composition of the Irish House of Commons tended to give some three or four large borough owners a prevailing power over that assembly. They, in conjunction with the Lords -Justices, who frequently had borough influence themselves, perhaps in imitation, albeit unconscious, of the English ruling families who governed Great Britain, owing to the ignorance of the country, and the language of George I. and George II., governed Ireland in the absence of the Lord Lieutenant, and, during his short stay in the country, were powerful factors in the direction of his policy, which they undertook to carry out in Parliament, the consideration open and avowed being a large share in the disposal of public patronage. To the influence of these "Undertakers" may be attributed the strange and sudden changes from opposition to support of the Government, followed quickly by recognition of 
services to the Government in the form of honours or emoluments. These startling political tergiversations were likewise in part attributable to the fact that the Party system had not in Ireland reached even its very imperfect development in England at that time. Above all, it should be remembered, in order to form a correct estimate of the powers of the "Undertakers," and subsequently of the Lords Lieutenant over the Irish Parliament, that in Ireland there never was Responsible Government, that is to say, an executive responsible to the Irish House of Commons, and, through them, to the Irish people. Motions of no confidence, of censure, framed in scathing terms, and rejections with contumely of cardinal measures of Government policy, were frequently passed by the Irish House of Commons. They effected no change in the Irish Government, who held office at the pleasure of an English Ministry, and vacated office on the resignation of that Ministry. The Irish Parliament could, no doubt, have taken the extreme measure of refusing to vote the supplies-a course not infrequently threatened, but never adopted, owing to the influences to which the House of Commons was subject.

Let us then consider the programme of a Patriot Party hampered by such conditions. In addition to the assimilation of the Irish to the British Constitution, reforms in administration claimed their attention in attacks on the Irish pension list, the tenure of great offices by absentees, and economy in the public expenditure. The revenue of Ireland was, as I have shown, so ample that its unconscionable disposal alone rendered it necessary to convene Parliament for taxation purposes. The chief of these abuses lay, no doubt, in the pension 
list and in the creation of sinecure offices. "The habit of quartering on Ireland," writes Mr. Lecky, " persons who could not be safely or largely provided for in England, was inveterate. The Duke of St. Albans, the bastard son of Charles II., enjoyed an Irish pension of $£ 800$ a year ; Catherine Sedley, the mistress of James II., had another of $f 5,000$ a year. William III. bestowed confiscated lands, exceeding an English county in extent, on his Dutch favourites, Portland and Albemarle, and a considerable estate on his former mistress, Elizabeth Villiers. The Duchess of Kendal and the Countess of Darlington, the two mistresses of George I., had pensions of the united annual value of $£ 5,000$. Lady Walsingham, the daughter of the Duchess of Kendal, had an Irish pension of $\ell_{1}, 500$. Lady Howe, the daughter of Lady Darlington, had a pension of $£_{500}$. Madame de Walmoden, one of the mistresses of George II., had an Irish pension of $£ 3,000$. The Queen Dowager of Prussia, sister of George II.; Count Bernsdorff, who was a prominent German politician under George I., and a number of less-noted German names may be found on the Irish pension list " (Lecky's History of England in the Eighteenth Century, II., p. 228). In I 701, when the destruction of the woollen trade had ruined Ireland, pensions, as I have stated, to the amount of $f_{1} 6,000$ were struck off, and, in 1729 , at the time of the great famine, a measure was carried by which all the salaries, employments, places, and pensions of those who did not reside six months of the year in Ireland were taxed $4 s$. in the $£$, but the unfortunate qualification was added, "unless they shall be exempted by His Majesty's sign manual" (History of England in the Eighteenth Century, II., p. 237). In 1753 this law had been suffered to drop, for it was 
found that the clause enabling the Sovereign to grant exemptions rendered it wholly nugatory. When Lord Townshend became Lord Lieutenant in 1767 , the pension list had increased to $£ 86,74 \mathrm{I}$. In 1757 the House of Commons had passed resolutions denouncing the increase of pensions as alarming, and compelled the Duke of Bedford, the Lord Lieutenant, by threat of withholding supplies, to forward them to the King. In 1763 the House agreed that pensions were an intolerable grievance, and in that year the Government of Lord Northumberland gave a distinct assurance that the King would not grant any more pensions for lives or years upon the establishment, except on extraordinary occasions (History of England in the Eighteenth Century, IV., pp. 365-367). George III. was cognisant of the bribery which was in England systematically used to secure Parliamentary support, and even personally advised and recommended "gold pills for an election" (see May's Constitutional History of England, I., p. 34I). $\mathrm{He}$ was, however, at the commencement of his reign, anxious to discourage corruption in Ireland. In a letter of instructions addressed to Lord Hertford, as Lord Lieutenant, in 1765 , the King writes : "Give no orders upon any letters of ours, either for pensions, money, lands, or titles of honour, unless such letters have been entered at our Signet Office. If warrants come to you contrary to these instructions, do not execute them. Should the revenue fall short of the cost of the establishment, you will take care that the same is not applied to the payment of pensions till the rest is first paid off. if there be not enough, you will abate the pensions" (Froude's English in Ireland, II., pp. 45-46). George III., who was alive to the impropriety of granting pensions 
in Ireland, was less scrupulous with his own disgraced relations. In 1774 he imposed a pension of $£ 3,000$ per annum on the Irish Exchequer for the benefit of his sister, the Queen of Denmark, who had just been banished for adultery with the Count Struensee.*

Then, again, the system which prevailed in full force of making lucrative sinecures, paid out of Irish revenues, rewards for English politicians living in England, and filling lucrative offices, not sinecures, by Englishmen, constituted a well-grounded grievance. Swift, in his " Fourth Drapier's Letter," published in 1724, gives a catalogue of the great Irish offices, some of them perfect sinecures, which were then distributed among English politicians. Lord Berkeley held the great office of Master of the Rolls, Lord Palmerston that of First Remembrancer, with a salary of nearly $£^{2,000}$ a year; Dodington was Clerk of the Rolls, with a salary of $£ 2,500$ a year ; Southwell was Secretary of State, Lord Burlington was Hereditary Lord High Treasurer, Mr. Arden was Under Treasurer, with an income of $£ 9,000$ a year ; Addison had a sinecure as Keeper of the Records in Birmingham Tower, and four of the Commissioners of Revenue lived generally in England. In the legal profession, every Chancellor till $\mathbf{1 7 8 9}$, and in the early years of the eighteenth century every Chief of the three Law Courts, was an Englishman. In the Church, every Primate during the eighteenth century was an Englishman, as were also ten out of the eighteen Archbishops of Dublin and Cashel, and a large proportion of the other Bishops (Lecky's History of England in the Eighteenth Century, II., pp. 227-228). Sir Hercules Langrishe, a distinguished Member of the Irish Parlia-

* Lecky's History of England in the Eighteenth Century, IV., p. $4^{\circ} 3$. 
ment, writing in 1769 , says: "The heads of the Church, the State, the Army, and the Law in Ireland have for a course of years been of another country. Of the twenty-two right reverend Prelates, the natives only furnish seven . . . . . . of the seven chief judicial offices two only are occupied by Irishmen. Of the fourteen great officers of the staff five only are of that country, and, besides all this, several of the principal employments are granted in reversion out of the Kingdom " (Considerations on the Dependencies of Great Britain, 1769, p. 46). The office of the Chief Secretary to the Lord Lieutenant owed its importance to the fact that the position of Principal Secretary of State was granted as a sinecure to representatives of three generations in the Southwell family - father, son, and grandson. Rigby, who had been Chief Secretary to the Duke of Bedford in 1759-1761, was given the sinecure offices of Master of the Rolls and Vice-Treasurer, which he held, living in England, till his death in 1789. " Single Speech " Hamilton was Chief Secretary to Lord Halifax and Lord Northumberland from 1761 till 1763 , when he was given, as a sinecure, the Irish Chancellorship of the Exchequer for life, with a salary of $£ 1,500$ per annum, being allowed to treat it as an absolute sinecure. In 1784 , after a long negotiation, he consented to sell it to the Government for the grant of a life pension in Ireland of $£ 2,500$ a year, which he was empowered to sell.* The excessive expenditure in public works, with which the Irish Parliament was charged, was owing to the failure, in 1753 , to gain authority over the surplus which had accumulated, which made succeeding Parliaments determine that no such surplus should occur again. It

* Lecky's History of England in the Eighteenth Century, VI., p. 373. 
was stated in the Irish Parliament that in the two sessions before $1753, f 400$ in each session was thought a sufficient bounty for public works, but that, in the succeeding ten years, not less than $£ 400,000$ had been voted for this purpose. During the four succeeding years the grants continued to increase (Lecky's History of England in the Eighteenth Century, IV., p. 356). One of the most wholesome rules of Parliamentary practice in England, embodied in a Standing Order of the House of Commons, dating so far back as the IIth June, 17 I $_{3}$, that the House will not proceed upon any motion for a grant or charge upon the public revenue unless recommended by the Crown, did not obtain in Ireland. The absence of such a rule accounts for the following episode, recorded in the reports of Sir James Caldwell, who was himself a Member of the House of Commons, of the debates of that body in $176_{3}$ and 1764 , illustrative of the temper and tone of the Irish Parliament of this period. It was moved that a Petition of the widow of a calico printer, praying aid to enable her to carry on her business, which was presented and read, be referred to a Committee. A discussion arose on the principle of political economy involved in grants for such purposes of public money. The mover of the Petition said he thought it very hard that he should be the first to be refused, and that he failed to see why he should not have his $j o b$ done as well as another. The word job grated on the House, and the following description of a "job" was given in debate: "The monosyllable Job is the name of a certain illegitimate child of Public Spirit, whom the world has agreed to call Job. He is well known in this House, and, I am sorry to say, has not been ill-received in it. Let me give an account of his 
descent and family character and qualifications. Selfinterest was the father by whom Public Spirit has numerous issue distinguished by the name of Job. Miny of them have come over here from a neighbouring country, and have, with great success, played both upon our weakness and our virtue. They very often assume their mother's name, and pretend that their father was Integrity, a gentleman of very honourable descent, who, having of late years been much neglected by persons of power and interest, has fallen into misfortune, and having been long in obscurity, nobody knows where he is. Of late, they (Jobs) have condescended to amuse themselves with great guns, howitzers, and mortars, with powder, ball-fire, and smoke, with warlike peace and peaceful war. As to the places where they are to be found, they have good company, and associate much with those in whom you place confidence. They are found at the Treasury Board, the Linen Board, the Barrack Board, and, in short, at every other Board. Nor are they ever to be missed at Grand Juries or Societies that have the disposal of money" (see Whiteside's Irish Parliament, pp. I I9-120). This humorous description of the corruption of the time may well be read in connection with some passages from a letter addressed by Lucas to Lord Halifax, one of Lord 'Townshend's immediate predecessors in the Viceroyalty, in which the scandals of Irish Administration and of the Irish Parliament are scathingly denounced. He thus refers to the Lords Lieutenant: "Your Excellency may easily look back and see the splendid figures some of the most necessitous of men put into this employment (the Lord Lieutenancy) have been able 
to render on their return home after enjoying this place for a session or two. See some of them and their worst tools loaded with excessive pensions for a number of years. Take a view of the favourites they have provided for in the Church, in the State, and in the Army. Your Excellency will often find the most infamous of menthe very outcasts of Britain-put in the highest employments, or loaded with exorbitant pensions, while all that ministered or gave sanction to the most shameful and destructive measures of such Viceroys never failed of an ample share in the spoils of a plundered people." He accounts for this appalling state of things in the constitution of the Irish Parliament. "Its Members are," he says, " a packed convention," and, further, so far from being elected by the people, that they are confessedly appointed in opposition to the sense of the electors, and held in servile bondage by some one man or junto of a few crafty persons grown rich and powerful by the spoils of a plundered and abused nation." "Serving the Crown," he adds, "is a phrase which in Ireland has been frequently extended to the giving money to a Minister for the erecting of forts, that, perhaps, were never intended to be founded, for arms that never were or will be made, or for raising funds upon any other frivolous pretence to enable a Viceroy to gratify himself and his no less mercenary minions with the most immoderate douceurs and boundless pensions. These are what have usually passed with us for serving the Crown, the King's business, and the like-and in long-lived Parliaments (the Octennial Act had not then been passed) a supple majority was seldom wanting to give sanction to the sordid deed, while a sufficient number of the Members were gratified 
with a share of the spoils" (Lecky's History of England in the Eighteenth Century, II., pp. 238-239).

Mr. Lecky has thus tersely summed up the apparent hopelessness of the political situation before the passing of the Octennial Act: "The attempt to resist (the régime of corruption) was almost hopeless. With the immense majority of the Nation wholly unrepresented, with the immense preponderance of legislative power concentrated in the hands of a few great men, who could be easily bribed by peerages or pensions, or of officials who were directly interested in the continuance of corruption, there was no real safeguard" (History of England in the Eighteenth Century, II., pp. 237-238).

The policy of Lord Townshend in Ireland was, like the policy of George III. in Great Britain in the early part of his reign, to overthrow the power of an oligarchy which had exceedingly flourished in the reigns of George I. and George II., and to substitute for it the power of the Crown. In each case the oligarchical leaders, to maintain their power, posed as the friends of popular rights and liberties, and in each case more corruption was employed to overturn their ascendancy than had cver been required to maintain it (Lecky's History of England in the Eighteenth Century, IV., p. 354). Immediately after the passing of the Octennial Act, the group of infiuential persons who had ruled the country in the absence of a Lord Lieutenant, and to whose power and influence a Lord Lieutenant in continuous residence would be fatal, showed their appreciation of the struggle between the Viceroy and the former Undertakers, which was imminent by the defeat of the Government through their influence in the House of Commons of an address acceding to a request embodied 
in a King's message laid before Parliament for a measure augmenting the number of soldiers $\mathrm{cn}$ the Irish establishment from 12,000 to 15,255 men.* The Parliament was dissolved in a few days afterwards. Townshend, in a letter to Shelburne, early in his Viceroyalty in December, 1767 , as one "being on the spot, and seeing the general disposition of the House of Commons," writes: "I know His Majesty did not mean to grant more pensions, nor could I give them hopes, though I could not help listening to their proposals. But, when I observed how very weak this Government had become, I thought it my duty to submit the matter again to His Majesty, being convinced that, until the system of government here can be totally changed, and the true weight and interest of the Crown brought back to its former channel, there must be some relaxation of this rule." $\dagger$ Immediately after the dissolution of 1768 he wrote to the Cabinet that the constant plan of " these men of power "-speaking of the Undertakers-" is to possess the government of this country and to lower the authority of English government, which must, in the end, destroy that dependence which this Kingdom-Ireland-has upon England. The aristocratic party must be broken. Every place, office, and honour must depend exclusively upon the favour of a resident Viceroy, so as to concentrate an overwhelming political influence in the Crown." After the Dissolution of 1768 , in recognition of services to the Viceroy, four Peers were raised a step in the Peerage, four new Peers, four Baronets, and four Privy Councillors were made, and Townshend urged the propriety of creating an Irish Order like that of the Thistle or the Bath, as a method of rewarding those members of the nobility

* Lecky, IV., p. 384. Froude, II., pp. 72-73.

† Frcude, II., p. 69. 
who were foremost in supporting the Government (Lecky's History of England in the Eighteenth Century, IV., p. 385). 'This suggestion was, fifteen years later, adopted by the establishment, from similar motives, of the Order of the Kinghthood of St. Patrick. "The ()ctennial Bill," wrote Lord Townshend on August 17th, 1769, " gave the first blow to the dominion of aristocracy in this Kingdom, and it rests with the Government to second the good effects of it."* Corruption was to be met by corruption, places and offices were multiplied, and pensions, notwithstanding royal prohibitions, lavishly conferred, while strong inducements were offered to the minor borough owners to dissociate themselves from the Undertakers, who were, however, still left undisturbed in their offices. The new Parliament met on October 17th, 1769, after nearly eighteen months' elaborate preparation by the Government to secure a majority, which proved to be unsuccessful.

Ponsonby, one of the Undertakers, who was the Chief Commissioner of the Revenue, with the patronage of the Customs Offices, in which, by various peculations, the Government was losing over $£_{150,000}$ a year, was re-elected Speaker without opposition. In the first trial of strength the Government was decisively beaten. The scheme of Army Augmentation, which had, in the last Parliament, been defeated by 108 to 104 , was now defeated by ro $_{4}$ to $72-\mathrm{a}$ defeat which, like many another defeat on questions of Ministerial policy of highest moment, was not, for reasons I have attempted to explain, followed by the resignation of the Government. Then the pension list, with all its scandals, was censured at the instance of persons who were aggrieved at not having themselves a share therein, but who, in this

* Lecky, IV., p. 386 . 
attack, had with them public opinion, to which that list was justly abhorrent. A Money Bill, moreover, which took its origin in the Privy Council, and had been sent over to England under the provisions of Poynings' Act, as one of the causes of the summoning of the new Parliament, was rejected, and a resolution was carried, stating that the Money Bill was rejected because it did not take its rise in the House of Commons. A course was here adopted which varied from that of the House of Commons of 1692, which was immediately prorogued, and not allowed to sit again by Lord Sydney. It was not denied that the Privy Council had the right to originate a Money Bill. It was only denied that it fell within the provisions of Poynings' Act, and that the Privy Council had the exclusive right. It was clained that the House of Commons had the right of origination also, and their right to reject a Money Bill or any other Bill was, of course, incontestable. The House of Commons carefully abstained from passing a resolution similar to the resolution of the House of Commons of 1692 , that "it is the sole and undoubted right of the Commons to propose Heads of Bills for raising money." In this case it was not stated whether the objection to the Money Bill, as not originating in the House of Commons, was on the ground of its being unconstitutional or inexpedient. The rejection of the Money Bill took place on November 2ist. Townshend was directed to follow the course of Lord Sydney-to prorogue Parliament, and not suffer it to sit again, if it were possible out of the hereditary revenues, as Lord Chancellor Phipps had hoped in the reign of Queen Anne, to carry on the civil and military establishments. The Lord Lieutenant, however, reported that the 
necessary cxpenses of the Government, even if pared down to the narrowest limits, were in excess of the revenue by $\{34.000$ !er annum, and that, if the establishment were maintained as at present, with the pension list included, the excess would be $£ 260,000$. The House of Commons, in order to checkmate any scheme of the kind, thwarted measures for a proposed reduction of the expenditure, and even introduced a motion carried by the casting vote of the Speaker, himself the head of the Revenue Department, on December 5th, 1769 , the effect of which, if carried into execution, would have largeiy reduced the fixed and permanent duties (see Froudie's English in Ireland, II., pp. 84-88; see also Lecky's History of England in the Eighteenth Century, IV., pp. 390-392.)

The Lord Lieutenant, accordingly, restrained his resentment for the time. The House of Commons, having rejected the Money Bill, proceeded immediately to draw a Bill of their own, in which practically the whole sum demancied by the Government was granted for the usual period of two years, while a vote of credit to the extent of $£^{100,000}$ was given to the Government. They also passed the Army Augmentation Bill. This studied moderation, after the striking of an effective blow, was one of the peculiarities of the Irish House of Commons, which may be explained by a knowledge of the conditions of Parliamentary and public life in Ireland which I have mentioned. Mr. Bowes Daly, a great Irish Parliamentary orator, sitting in the Irish House of Commons beside Mr. Hardy, the biographer of Lord Charlemont, thus commented on the moderation in the emphasising of triumphs in the Irish Parliament : "Bowes Daly," writes Mr. Hardy, "once made an 
observation to me which showed such a general knowledge of the Irish House of Commons, that I never shall forget it. On some question, no matter what, the Court was either left in a minority or obliged to withdraw it. Some Member attempted to pursue this apparent triumph by a more decisive resolution. 'How little is he acquainted with this House,' said Mr. Daly. "Were I a Minister, and wished to carry a very untoward measure, it would be directly after we had passed some strong resolution against the Court. So blended is the good nature of Irish gentlemen with their habitual acquiescence, that, unless Party or the times are very violent indeed, we always wish to shrink from a second resolution against a Minister, and to make, as it were, some atonement for our precipitant patriotism by as rapid a return to our original civility and complaisance " " (Hardy's Life of Charlemont, I., pp. 282-283). On the 2oth December, 1769 , the Lord Lieutenant went down to the House of Lords, and, having summoned the House of Commons, he thanked them for their liberal supplies, and then delivered a solemn protest against their resolution as an infringement of Poynings' Law, directed that his protest should be entered on the Journals of each House, and at once prorogued Parliament, which was not allowed again to sit for fourteen months, but was prorogued at intervals from three months to three months. The protest was entered on the Journals of the House of Lords, but the House of Commons, before separating, forbade their Clerk to enter it in their Journals.*

$$
\text { *Lecky, IV., p. } 392 .
$$


$\mathrm{X}$.

\section{THE METHOD OF SECURING A PARLIAMEN- TARY MAJORITY FOR THE GOVERNMENT.}

THE Parliament of Ireland which had been prorogued on December 26,1769 , under the circumstances I have cndeavoured to sketch, was not convened till February 26, 1771. The prorogation of a Parliament which had sat for a period little exceeding two months before it had any opportunity of serving public interests, but, as it appeared, had only been called to vote supplies to the exclusion of every other business, was a matter of severe stricture both in England and Ireland, and Lord Townshend and his Administration were the subjects of able and acrimonious attacks in the Press, to which Flood, Grattan, and Langrishe were powerful contributors. Lord Townshend did not follow the precedent of r692, when the Parliament was dissolved. He was determined to bring a recalcitrant assembly into subjection by coarse metallic corruption, and to cause the Irish Parliament which bitterly opposed him in 1769 to stultify itself by its servile adulation of him in 1771 . The fourteen months of the Parliamentary recess were spent by the Viceroy, who was resident in Ireland during that recess, in purchasing a majority for his Government, and turning a House of Commons opposed to that Government into supporting the Administration by means akin to the methods whereby at a later period the Parliament which rejected the Union in 1799 carried that measure without a dissolution in 1800 . 
Townshend's methods were simple but profound. $\mathrm{He}$ aimed at the overthrow of the Undertakers by detaching their supporters, and bringing them into subjection to his influence. On the 23rd December, 1769, three days before the prorogation, the Lord Lieutenant wrote asking for leave to remove Lord Shannon, who was Master of the Ordnance, and Ponsonby, the Speaker, who was head of the Revenue Board, from their positions under the Crown, and for liberty to remodel the Irish Privy Council. In due course the permission sought for by the Lord Lieutenant was granted, and "the unworthy servants of the Crown" were dismissed from office with all their subordinates and dependents-the entire Departments of the Ordnance Board and the Revenue Board being changed to a man. At this time there was no Place Act in Ireland, and Parliamentary status was unaffected by the acceptance of office under the Crown. Many of the large borough owners were brought into political alliance under the Lord Lieutenant by fear of loss of office or by promise of appointment to office and of promotion in the peerage, while on their nominee Members in the House of Commons, who were bound by the etiquette of the time to vote on cardinal questions of public policy in accordance with the wishes of their patrons, offices and titles and in many cases large sums of public money were bestowed. It was indeed openly stated in the Irish House of Commons in 1789 that half a million sterling had been expended in bringing this Parliament into harmony with the Government. Seven peerages were instantly conferred. The Prime Sergeant, Hely-Hutchinson, obtained an addition of $f_{1}, 000$ a year to the salary of his sinecure office of Almoner, and it is said that pensions amounting 
to $£ 25,000$ per annum were promised. All patronage, legal, ecclesiastical, military, and political, was employed to the same end. "The gentlemen of the House of Commons were taught to look up to the Viceroy, not only as the source, but as the dispanser of every gratification" (Lecky's History of England in the Eighteenth Century, IV., PP. 395-396; Camphell's Philosophical Surzey, p. $5^{8}$ ).

Nor was it merely to the "trade of Parliament" the entering into sordid arrangements whereby favours were promised for support in Parliament that Townshend applied his energies. He knew well how powerfully the attractions of a Court, levées, drawing-rooms, profuse hospitality, and lavish expenditure can prevail in bringing popularity and in gaining an influence which will re-act on politicians. Mr. Froude thus describes this aspect of Townshend's campaign in securing a majority in Parliament: "He gave masquerades, he gave fancy balls, in which the costumes, with a skilful compliment to Ireland, were made only of Irish manufacture. The Members of the Opposition sneered and would have stayed away; the wives and daughters refused to excluce themselves from assemblies of which the capital of Ireland had never seen the equal, and forced their husbands and fathers into submission " (Froude's English in Ireland, II., p. 98). He likewise displayed considerable political foresight in making suggestions to the English Cabinet for a partial relaxation of the commercial restrictions which weighed so heavily on Ireland, and were destined a decade later to be removed by the force of the Volunteer Movement.

At length, on the 26th February, 1771, the Irish Parliament, whose Members had been in training for 
upwards of a twelvemonth in a course of corruption, met. Wide was the change in tone of a body which was practically composed of the same men who had passed the celebrated Money Bill resolution of December, 1769 . The Ponsonby-Shannon group were minished and brought low, and the converts to the Lord Lieutenant's powers of gentle suasion were in the ascendant. An Address to the King was moved by the younger Ponsonby in reply to the Speech from the Throne, from which the usual words of compliment to the Lord Lieutenant, thanking the King for retaining him in the Lord Lieutenancy, were studiously omitted. An amendment inserting the words " To return our most humble thanks to His Majesty for continuing His Excellency Lord Townshend in the Government of this Kingdom " was proposed and carried by 132 to 107 . The ex-Undertakers, when expelled from the management of the country, posed, like many other disappointed place-mongers and place-beggars, as friends of popular rights. The amendment to the address was used to excite the clamour of the people, and was the occasion of a furious riot outside Parliament House next day, which was quelled by the military, who remained guarding the building while the Houses were sitting. A resolution moved by Flood, that the House was being overawed, was defeated by 99. to $5^{\mathrm{I}}$; another resolution likewise moved by him, to declare the undoubted rights of the House of Commons to originate Money Bills, was defeated by 128 to 105 . The Address to the Throne was agreed on, with the addition of a paragraph moved by Sexton Pery, that while the Commons were incapable of attempting anything against the rights of the Crown, they were tenacious of the honour of being the first movers in granting supplies, 
and they besought His Majesty not to construe their zeal into an invasion of his authority. The address to the Lord Lieutenant, the double ceremony being invariably observed, was then moved and carried. It devolved upon Ponsonby, as Speaker, to present it, but he, in a very dignified letter announcing his resignation of the Chair, declined to submit to what he regarded to be a humiliation. "He had desired," he wrote, " to preserve and transmit to his successors the rights and privileges of the Commons of Ireland. In the last Session it had pleased the Lord Lieutenant to accuse the Commons of a great crime. In the present Session it had pleased the Commons to take the first opportunity of testifying their approbation of His Excellency by voting him an address of thanks. Respect for their privileges prevented him from being the instrument of delivering such address, and he must request them to elect another Speaker." Pery was elected in his place by the narrow majority of four votes in the Session which lasted till May. Heads of a Bill for the encouragement of Agriculture passed by the House of Commons were rejected by the English Privy Council, because the Bill would add to the expenditure, while the Heads of a Bill likewise passed by the House of Commons, devised to prevent corn from being wasted on whisky-making, was also, notwithstanding the earnest recommendation of the Lord Lieutenant that it should be returned, rejected by the English Privy Council because it would be a loss to the revenue. The representations of the Lord Lieutenant to the Cabinet on the impropriety of restraints on Irish trade in favour of English merchants were renewed, but failed to make any impression.* This Parliamentary majority

* Froude's English in Ireland, II., pp. I10-I I 4. 
was only maintained by the most constant and lavish corruption. We find the Lord Lieutenant in March, $177 \mathrm{I}$, asking for commissions for the relations and dependents of his Parliamentary friends on hearing that a regiment for the East India Service is to be recruited in Ireland.* And in May, 1771, he seeks for eight more promotions to the Peerage and recommends three or four Members of the House of Commons as Peers. He added to the number of Commissioners of Account, notwithstanding the passing of a resolution by the House of Commons that the existing seven Commissioners were sufficient, and divided the Customs and Excise Department; five new places of $f_{5} 500$ a year being created, and all of them being bestowed on Members of Parliament. $†$ The Viceroy, however, was wholly unable to satisfy the cupidity of his venal supporters, who, on the meeting of Parliament in October, 1771 , renewed their attacks upon his Administration. A proposed addition to the Address to the Throne, moved by Lord Kildare, that " we lament that we cannot enumerate among our blessings the continuance of Lord Townshend in the Government of Ireland," was rejected by a much diminished majority, whilst Flood carried by a majority of no less than forty-six a resolution condemning the alteration in the constitution of the Revenue Board. A vote of censure was passed on the Government for the conferring of a pension on one Jeremiah Dyson and his three sons of $f \mathrm{r}, 000$ a year on Irish establishment. A clause introduced among the additional duties protecting Irish linen from the importation of cotton manufactures from the Continent was struck out by the English Privy Council. The Eill

* Lecky's History of England in the Eighteenth $\dot{C}$ entury, IV., p. 396. † Ibid., p. 397. 
Bo aliered was rejected. Heads of a new Bill with the clause inserted were passed and sent back without a moment's delay. The Government only succeeded by a majority of 12 in defeating a vote of censure directed against the King's letters, reimbursing by a fresh grant in the case of a few eminent persons the tax of $4 \mathrm{~s}$. in the pound which the Irish Parliament had imposed on all places or pensions held by absentees. When the reply cance from the King in February, 1772 , stating that he regarded it as his duty to maintain the charges made on the Revenue Board, notwithstanding the objections of the House of Commons, several angry motions-one that the $\mathrm{n}$ aintenance of the new Commissioners was an indignity to Parliament, another that the House should record its dissent from the message from the Throne-were carried, while on the igth February a resolution was carried by the casting vote of the Speaker that whoever had advised the increase in numbers of the Commissioners had advised a measure contrary to the sense of the Legislature.* Then there came an astonishing change in the temper of the House of Commons. In the very same assembly which had passed votes of censure repeatedly on the Lord Lieutenant, by a startling rolte face, an address was carried to him declaring entire satisfaction with his Administration. The change was brought about by an overture made by the Lord Lieutenant to Lord Shannon, who consented for place and power to break away from Ponsonby and to support him with his enormous Parliamentary influence. $\dagger$ At last, in September, 1772 , the British Cabinet determined to bring this disgraceful administration to a close.

* Lecky's History of England in the Eighteenth Century', IV., p. 399. Froude's English in Ireland, II., pp. I I 6-123.

$\dagger$ Froude's English in Ireland, II., p. I24. 
Nearly the last letter of Lord Townshend before he left Ireland asked for a peerage for the wife of HelyHutchinson, and for peerages and baronetcies for seven Members of Parliament in return for their votes. The following proposed amendment to the Address of thanks to Lord Townshend, voted by the House of Commons at the conclusion of the Session in May, 1772, presents, in my judgment, a picture of his administration in Ireland despite the passing of the Octennial Act: " And we cannot sufficiently congratulate your Excellency on your prudent disposition of lucrative offices among the Members of this House, whereby your Excellency has been enabled to excite gratitude sufficient to induce this House to bear an honourable testimony to an administration which, were it not so beneficial to individuals, must necessarily have been represented to His Majesty as the most exceptionable and destructive to this kingdom of any that has ever been carried on in it. The carrying into execution the division of the Revenue Board, contrary to the sense of this House, we should have considered and represented as a high contempt of Parliament. But from the distribution of the multiplied seats at the two Boards now instituted among Members of this House, we entertain a very different sense of that measure, and conceive that it was carried into execution not from contempt, but the highest veneration of Parliament, the indignation of which you dreaded, and therefore thus averted. And we assure your Excellency we are very, much obliged to you for the offices which you have bestowed upon us. We also return you thanks for instituting offices for us at a new Board of Accounts, which, however unnecessary for the public service, we find very serviceable to ourselves."**

* Froude's English in Ireland, II., p. I24. 
XI.

THE IRISH PARLIAMENT AND A SINISTER

ADMINISTRATION.

LORD TOWNSHEND's Viceroyalty began the period of the Irish resident Viceroy instead of the Irish migratory Viceroy, whose residence in Ireland was confined to the Parliamentary Session, which was then held biennially. In his Viceroyalty, likewise, the régime of the Undertakers was terminated and the régime of the Lord Lieutenant as a dispenser of patronage began. The system of governing the country by Undertakers was one of hopeless corruption, and the system of Viceregal Government by which it was succeeded was even more corrupt and more expensive. George III had, as we have seen, early in tis reign, given personal instructions to Lord Hertford on his appointment to the Viceroyalty to put down corruption. Instructions of the same character had been given to Lord Townshend by the English Cabinet. We have seen that in his Viceroyalty offices, pensions, peerages, had been lavishly bestowed avowedly as the rewards of corruption, by which alone the work of the Government could be carried on. Lord Harcourt, who had the advantage of succeeding immediately a most unpopular predecessor, had also received instructions to discourage all applications for new peerages and promotions, additional pensions and salaries, new offices, employments for life, and all grants 
of revenue, as well - $s$ the sale of offices, places and employments. He was also instructed to do his utmost to regain for the King the full control of the hereditary revenue by inducing the Parliament to make good by taxation the many charges which had been thrown upon it in the form of pensions and bounties. (See Lecky's History of England in the Eighteenth Century, IV., p. 402.) Lord Harcourt arrived in Ireland in November, 1772. Parliament was not to meet till the Uctober following. He received in March the direction to which I have previously referred from Lord North, the Prime Minister, who, like George III., was alive to the impropriety of granting pensions, to the effect that the King had determined to place his disgraced sister, the unfaithful wife of the King of Denmark, on the Irish establishment as the recipient of a pension of $£ 3,000$ per annum.* The Administration of Lord Harcourt, which has been characterised by a writer so little disposed to form a severe judgment as Hardy, as " a sinister administration," carricd the system of corruption established by Townshend to a still greater excess. Hardy, who may be regarded as reflecting the sentiments of Lord Charlemont, thus described the methods of Government in the Harcourt régime from 1772 till 1776 : "The recall of Lord Townshend," he writes, "was grateful to some gentlemen who indulged the hope that his successor's Administration might proceed on more constitutional principles. They did not, therefore, join Lord Harcourt's Government, but were prepared to give him such support as, in their opinion, he might be justly entitled to. Too many, however, laid hold on Lord Townshend's departure not as an apology for but an

\footnotetext{
"Lecky's History of England in the Eighteenth Century', IV., p. fo3.
} 
entire justification of their abandonment of the party to which they had hitherto adhered. In the true cant of political hypocrisy and tergiversation they said : ' It is highly indecorous that every Lord Lieutenant should be indiscriminately opposed. We could not conscientiously join Lord 'Townshend, but we may certainly support Lord Harcourt.' This was abstractedly fair, had they upheld Lord Harcourt's Government upon principles of candour and disinterestedness. But how did they support it? As all such apostates have ever supported any Viceroy! Besieging his doors, besieging those of the Secretary night and day, soliciting every employment, courting every service at the Castle, unresisting sycophants in the House of Commons, adventurous braggadocios hourly insulting the public whom they robbed, and by their rapacity hourly weakening the royal authority which, with an audacious temerity, they affected exclusively to maintain. It is deeply to be deplored that any Secretary should be obliged to enlist such mercenaries, and had this Administration aspired to any loftiness of station or measures of great and permanent utility it might have laughed their mendicancy to scorn. But it was soon discovered it was a Government of patronage, of multiplied arrangements. Such a Government will always be weak, though it appears to superficial observers exactly the contrary. But having no public measures to rest on, no confidence of the people to resort to, it will be always upheld by the servile and the venal; their solicitations are necessarily complied with, their numbers pass for strength, their misdeeds for spirit, but all is hollow" (Hardy's Life of Charlemont, I., pp 318-319). 
I have quoted this passage at considerable length, because, in my judgment, it is a very admirable description, by a writer who had the experience of a member who sat in the three last Parliaments of Ireland in the House of Commons, of a system of conducting the government of the country which he actually saw. It, moreover, gives a sketch in all its salient features of the typical corruptionist Member of the Irish Houses of Lords and Commons, who was at all times the weakness and disgrace, and eventually the ruin, of the Irish Parliament. No less than $f 80,000$ was added in this Administration to the public expenditure of Ireland. Several thousands of pounds were spent in creating new offices or annexing new salaries to old ones, and, in the words of Grattan, "there was scarcely a sinecure whose salary Government had not increased." It was no longer possible to urge that the public revenue was largely wasted in private grants for stimulating private enterprises. Most of the new expenses emanated trom the Government itself. "Candid men," writes Mr. Lecky, "were obliged to confess that the old system of Undertakers was much more economical and was certainly not more corrupt than that which had succeeded it." (History of England in the Eighteenth Century, IV., pp. 44I-442.)

Lord Harcourt, as we have said, came to Dublin in November, I772, and Parliament was not to meet till October, I773. The Lord Lieutenant had accordingly ample opportunity of becoming acquainted with the friends of Administration, and of being introduced, in the words of Mr. Froude, to the "mysteries of corruption" in which his Chief Secretary, Sir John (Lord De Blaquiere) Blaquiere actually revelled.* The

* Appendix IX. 
possessors of powerful borough influence in the House of Commons and the Members of that body who represented themselves exceedingly well were prepared to give Lord Harcourt a fair trial. Lord Shannon very plainly stated his terms. He asked for one peerage, one pension, and four appointments - the Governorship of Cork, the position of Prime Serjeant, a Commissionership of Revenue, and a Bishopric for his protégés. In the first Session of Pariiament after his appointment to the Lord Lieutenancy, Harcourt obtained great popularity by re-uniting the Boaids of Excise and Customs, whose division under Lord Townshend, with the creation of a large number of Parliamentary offices, had created great indignation. The economy, however, thus effected was more apparent than real. Five Commissioners and four Surveyors-General were compensated by pensions for the extinction of their posts.*

Lord Harcourt's Administration is mainly to be remembered for the defeat, by a cunning contrivance, of the Absentee Tax, which was apparently favoured by the Government, and would have enormously lightened the buriens of the people and eased the financial difficulties of the country; the winning over of Flood, who was then the leader of the Country party, to the Castle interest, by his appointment to the sinecure post of Vice-Treasurer of Ireland with a salary of $£, 3,500$ a year, and the purchase of a Parliamentary majority in favour of the war of Great Britain against her American Colonies, to which the Irish people were wholly opposed.†

The Irish Treasury was over $\& 300,000$ in arrear, and the revenue was falling off owing to the stoppage of the

\footnotetext{
* Lecky's History of England in the Eighteenth Century, IV., pp. 402-403. Froude's English in Ireland, II., p. I60.

$\uparrow$ Appendix X. Appendix XI.
} 
Colonial trade. A reduction in the Pension List, which had nearly doubled in the last twenty years, was considered, having regard to the methods of Irish Government, unthinkable. In these circumstances, Harcourt determined to recommend, and Lord North agreed to accept, if it were carried in Ireland, a tax of $2 s$. in the pound on the rents of absentee proprietors. The drain on the resources of the country, from vast sums of money being deported to be expended elsewhere, had always been in Ireland an all but intolerable grievance, and many efforts were made to lighten that grievance, to some of which reference has been previously made. These proceedings may be briefly stated. In I729, at the time of great famine, a measure was carried by which all the salaries, employments, places, and pensions of those who did not reside six months in the year in the country were taxed four shillings in the pound, but the unfortunate qualification was added: "unless they shall be exempted by His Majesty's sign manual."* In $175^{1}$ this statute was repealed, the exemptions to which it was subject having made it practically a dead letter. In 1767 the Government consented to accept a reenactment of the old law imposing a tax of $4 \mathrm{~s}$. in the pound on absentee placeholders and pensioners, with the omission of the clause authorising the Sovereign to exempt those whom he pleased from its operation. In 1770 a vote of censure directed against the Kinn's Letters reimbursing by a fresh grant in the case of a few eminent persons the tax of $4 \mathrm{~s}$. in the pound imposed on all places $\mathrm{cr}$ pensions held by absentees, was repelled by 12 votes only in the Irish House of Commons, the contention being unanswerable that the Act was a mockery if a new grant of $4 \mathrm{~s}$. in the pound were to be

* Lecky, II., p. 237. 
macie to the pensioners out of the Irish revenues in order to compensate them for the tax.* The great Irish absentee Whig Peers, represented by the Duke of Devonshire, the Marquis of Rockingham, the Earl of Bessborough, Lord Milton, and Lord Upper Ossory, issued a public letter in opposition to the proposal. The manifesto, which is one of the most powerfully written State documents of the time, is the composition of Edmund Burke, who, on this occasion, acted rather as a mouthpiece of an English party than an advocate of Irish rights, and was well aware that the measure, which was the subject of a denunciation written by him, but signed by titled personages who were deeply personally interested in the matter, was consonant with the wants and wishes of the Irish people. "If," he wrote to the Marquis of Rockingham, " Government here (in England) persists in countenancing such a plan, I have no sort of doubt that it will pass the Parliament and Privy Council of Ireland not only without difficuly, but with the greatest satisfaction and applause." $†$ The great English Companies, who were also large owners of $I_{1}$ ish property, likewise joined in fierce opposition to the measure, and arrangements were made by all the absentee land-owners, whether individuals or Corporations, to appear before the English Privy Council by the most eminent members of the Bar in resistance to the Heads of the Bill in the event of its transmission to England. The Absentee Tax Bill was defeated in the Irish House of Commons by the treachery of the Irish Lord Lieutenant himself in the adoption of a course which he thus explained in a letter written on November 9th, 1773, to the English Cabinet: "The decided opinions," he wrote, " of some of the wisest and most experienced men in this

$$
\text { *Lecky, IV., p. 399. †Froude, II., p. I69. }
$$


Kingdom, and the general wishes of the people for half a century past, added to the exigencies of Government, led me to press it on your Lordship. This, however, iike every other mode of taxation, must naturally irritate those whose hitherto untaxed estates would principally be affected by it, and be attended with inconveniences, though inadequate to the advantages it must produce. Not to embarrass your Lordship, as soon as I saw how things were going, with the help of our friends here I have obstructed the progress of the tax. We mean to allow it to be moved by a certain wild, inconsistent gentleman, who has signified such to be his intention. This will be sufficient to damn the measure, though no other means be employed against it. Opposition are first made to startle and by degrees grow alarmed at it, as an approach to a general land tax. As to our own people, by speaking indecisively and equivocally to those who seem to wish (sic) against it, and by setting those at defiance who wish to extort favours by a compliance with any requisition of the Government, men in general have been brought to hold themselves in suspense with regard to it."* The letter of the five Lords, Lord Harcourt said he could have used with effect if he had wished the Bill to pass to create exasperation against the absentees. "Having, or at least wishing to give up the object, I will endeavour to make these letters a means of condemning the tax in the House of Commons. It will in course grow a topic of general observation and discussion, and, from a capricious instability observable in the opinions of the people of this country, I imagine that by leaving men now totally to their own inclinations this now so much sought for boon may die in a few days, and if it should not of itself, very little addition to what

$$
\text { *Froude, II., pp. 166-I67. Lecky, IV., p. 4II. }
$$


has already been done on our part shall be made to destroy it."

Before the measure came formally before the House of Commons, there was an incidental reference to it which Sir John Blaquiere, the Chief Secretary, co-operating with the Lord Lieutenant, turned to good account by damning the projected legislation with faint praise. He had heard, he said, the Absentee Tax very lately described as the salvation of the country, and he had not yet quite griven up the idea, though his faith may have been somewhat staggered by the variety of opinions which now obtain. They had not convinced him. He adhered to his own impression, but he desired the House to understand that the Administration would be guided entirely by the judgment of the Irish Parliament. "I will lay my heart upon your table," he concluded. "Under the strange revolution of sentiment which this subject has already undergone, let it surprise no man if upon this occasion my best friend and I divide on different sides of the House." $\dagger$ On the 25th November the question came directly before the House of Commons. 'The debate lasted till two o'clock in the morning. The proposal was that a tax of two shillings in the pound should be laid on ail net rents and profits payable to persons who did not reside in Ireland for six months in the year. The equity of the tax was universally admitted, but Lord Harcourt's treacinerous suggestions, as related by himself, were not forgotten. "They did unanimously," he says, writing to Lord North on the day the division was taken, " and in the most violent manner

*Lecky's History of England in the Eighteenth Century, IV., pp. 4I I-4I2. Froude's English in Ireland, II., pp. I66-I67.

† Froude's English in Ireland, II., pp. 167-I68. Lecky's History of England in the Eighteenth Century, IV., pp. 412-415. 
inveigh against the insidious and deep designs of the English Government to introduce by these means a general Land Tax." Some of the leading interests turned against the measure, and it was rejected by 120 to 106 . "Thus," wrote Lord Harcourt to Lord North, " the long expected measure which for ages has been the subject of their discourse, the warmest object of their complaints and wishes, and still within these three months considered as too important an acquisition ever to be hoped for by their country, has been rejected by a majority of fourteen." An attempt was made next day to reconsider the question, but after a debate of nine hours' duration, the motion for reconsideration was, "by most dexterous management "- to use the words of the L.ord Lieutenant-rejected without a division. Lord North congratulated Lord Harcourt on having defeated an Irish measure of priceless service to Ireland, but prejudicial to the personal and pecuniary interests of a few individuals and corporations, "without any promises of peerage or pension." Lord North's letter of congratulation to Lord Harcourt was one of grateful acknowledgment. "Your Excellency's campaign," said the Prime Minister, " has been most glorious and successful. The Irish Government will now be carried on with credit and tranquillity. His Majesty is extremely pleased with you."** I have related this episode at considerable length owing to the fact that it throws light on the duplicity which characterised the dealings of the English Government with the Irish Parliament, and the caprice and instability of the self-seekers who were in so large a majority in the Irish Parliament.

The Absentee Tax, having been rejected, the Customs

* Froude's English in Iveland, II., pp. I69-I74. 
Duties had been raised to cover the deficit. The Heads of three Supply Bills had been sent to England, but the irritating practice of making alterations in them was again pursued. Two of these Bills were unanimously' rejected. Harcour $i$ warned the Government that the alcerations were regarded as "wanton, unnecessary, and unkind," and that, if the Bills were altered again, they would not be passed. The Commons proceeded to re-enact the Bills with new titles, and they came back from the English Privy Council without alteration.*

The rejection of the Absentee Tax naturally turned public attention to the commercial restrictions to which Irish trade was subjected by English Governments, and to the enforced emigration from Ireland of the most highly-trained artisans. Ireland had manufactured hemp and flax, to whose manufacture she had been restricted by English legislation, to such good purpose as at one time to supply sails for the whole British Navy. England had now laid a disabling duty on Irish sail cloths, which had injured Ireland without conferring any benefit on English trade. The British market was supplied from Holland, Germany, and Russia, while to the Empire the result was only the ruin of Ulster and the flight of the Protestant population to America. Mr. Pery, the Speaker of the Irish House of Commons, in presenting the Supplies to the Lord Lieutenant at the Bar of the House of Lords on December 26th, 1773, made a formal representation of the impropriety and injustice of English interference with Irish industries, which is a proper sequel to the history of the Absentee Tax. All the subsequent proceedings in favour of the extended

* Froude's English in Iveland, II., pp. I 75-I 76. Lecky's History. of England in the Eighteenth Century, IV., pp. 413-4I4. 
commerce of Ireland were founded on this representation, to which reference is made in a note among the papers of Lord Charlemont, the Leader of the Volunteer Movement, by which trade restrictions were removed from Ireland. "In Lord Harcourt's time the liberty of trade was begun by a speech of the Speaker's." (Hardy's Life of the Earl of Charlemont, I., p. 343.)

"The Commons," said Mr. Speaker Pery," "have exerted their utmost efforts to answer your Excellency's expectation, not only in providing for the discharge of an arrear of $f_{2} 265,000$, but also in mairing an addition to the revenue of near $f_{\mathrm{N}} 100,000$ a year. Difficult as this rask appeared in a Kingdom so destitute of resources as this, yet it was undertaken with cheerfulness and prosecuted with vigour, but if the means which they have employed shall prove inadequate to the liberality of their intentions, it must be imputed to the inability of the Kingdom, not to any disinclination or unwillingness in them to make ample provision for His Majesty's service to which they have sacrificed their most favourite objects. The moderation and temper with which all their proceedings have been conducted during the course of this Session afford the most ample proof not only of gratitude for $\mathrm{His}$ Majesty's attention and condescension to their wishes, but also of the just sense they entertain of Your Exceilency's intercession in their favour, and they have the fullest confidence that the same humane and benevolent disposition will induce Your Excellency to represent to His Majesty in the strongest light not only their duty and affection to him, but also the state and circumstances of this Kingdom, from which they conceive the most sanguine hopes that those restrictions which the narrow and short-sighted policy of former times, equally injurious

*Appendix XII. 
to Gieat Britain and to us, imposed on the manufactures and commerce of this kingdom will be remitted. If Great Britain reaped the fruits of this policy, the Commons of Ireland would behold it without repining, but it aggravates the sense of their misfortunes to see the rivals, if not the enemies of Great Britain, in the undisturbed possession of these advantages to which they think themselves entitled upon every principle of policy and justice. It is the expectation of being restored to some, if not to all, of those rights, and that aione, which can justify to the people the conduct of their representatives in laying so many additional burdens upon them in the course of this Session, and no time can be more favourable to their wishes than the present, when the public councils are directed by a Minister who has judgment to discern and courage to pursue the common interest of the Empire, and when the Throne is filled by a monarch the sole object of whose ambition is to render all his people happy." (Hardy's Life of Lord Charlemont, I., pp. 34r-343.)

In a very few years the line of policy thus advocated was enforced by the Irish Parliament, backed by the Irish Volunteers.

And then again the Harcourt Viceroyaity was marked by the acceptance of office under the Crown by Mir. Flood, who had, in a Parliamentary career of great brilliancy, been for upwards of seventeen years the foremost advocate in the House of Commons of popular rights and liberties, including in his programme the shortening of the duration of Irish Parliaments, which was achieved in 1768 ; the removal of the scandals of the Pension List, the modification - if not the repeal-of Poynings' Law, the establishment of an Irish Militia, and had opposed 
the increase of offices and the Government influence in Parliament thereby secured, and come forward as the protagonist of the Absentee Tax. In 1775, after a long negotiation with the Government, Flood accepted the sinecure office of Vice-Treasurership of Ireland at an annual salary of $£ 3,500$ a year. The Irish ViceTreasurerships, of which there were three, had invariably been filled by Members, not of the Irish but of the English Parliament. Lord Harcourt, in announcing the conclusion of his negotiation with Flood to Lord North, speaks of the true inwardness of Flood's appointment to office with an exquisite directness and candour which leave no room to doubt that His Excellency regarded his conduct in the matter as a diplomatic triumph of the same character as his success in strangling the Absentee Tax while posturing as the friend of that measure. " Since I was born," wrote the Lord Lieutenant to Lord North, "I never had to deal with so difficult a man, owing principally to his high-strained ideas of his own great importance and popularity. But the acquisition of such a man, however desirable at other times, may prove more than ordinarily valuable in the difficult times we may live to see, which may afford him a very ample field for the display of his great abilities."*

"For seven years," writes Lecky. "Flood was silent in office while the questions which he had first brought forward were rising rapidly to the front, and when at last he broke from the Government he found that his place was filled and that he was no longer trusted and followed as of old. In the very session in which he accepted office (October, 1775), his great rival, Grattan, took his seat in the Irish Parliament." $\dagger$

* Lecky's History of England in the Eighteenth Century, IV., pp. $427-428$.

$\dagger$ Lecky, IV., pp. 428-429. Froude's English in Ireland, II., pp. I $84-189$. 
And then Lord Harcourt, by resort to the corruptionist agencies and influences by which he had defeated the Absentee 'Tax Bill, and had placed in official harness the greatest leader of Opposition who had yet appeared in Irish Parliamentary history, achieved a triumph on whose accomplishment he declared in a confidential letter to the British Cabinet on October II, 1775: "I have never passed moments so happy as these have been since the question was determined." The matter to which the Lord Lieutenant thus alluded was the sanction and support of the Irish Parliament in the attitude of the British Government in relation to the American Colonies in the War of the American Independence, although, in the great words of Lord Chatham, whose advocacy of American rights made him a hero in Ireland, and gave his name to two streets in the City of Dublin, "Ireland was with America to a man."* The controversy between Great Britain and the North American Colonies had been watched at its every stage with a microscopic eye in Ireland, whose history, associations, and circumstances invested the question with an absorbing national interest. The American colonists were largely composed of IrishmenProtestants who had been driven from Ireland by the restrictions placed by English legislation on Irish trade and industry, and by the rapacity of Irish landlords, and Catholics who, in their own land, had been subject to the oppression of which their Protestant fellow-countrymen were victims, with the additional tyranny of the atrocious Penal Code system. Their fellow-countrymen in Ireland knew that the Irish and American questions were attended with so many parities of circumstance

* 'Thackeray's Life of Chatham, II., p. 286. 
as to be practically identical. "The question in both countries," writes Froude, "was substantially the same, whether the Mother Country had a right to utilise her Dependencies for her own interests, irrespective of their own consent." (English in Ireland, II., p. 189.) English lawyers had sometimes asserted and sometimes denied the existence of the right of the English Parliament to make laws for Ireland, but the first explicit Act in its favour was the Declaratory Act of George I., by which the English Parliament asserted its own right of legislating for Ireland. It was precisely parallel to the Declaratory Act which was passed when the Stamp Act was repealed, affirming the right of Parliament to make laws binding the British Colonies " in all cases whatsoever," and condemning as unlawful the votes of the Colonial Assemblies which had denied to Parliament the right of taxing them.

"In both cases," writes Mr. Lecky, " the right was denied, but in both cases the great maiority of politicians was practically ready to acquiesce, provided certain restrictions and limitations were secured to them. The Americans did not dispute the power of the English Legislature to bind their commerce and regulate their affairs as members of an extended Empire as long as they were untrammelled in their local concerns, and were not taxed except by their own representatives. The position of most Irish politicians was very similar. The Irish Parliament legislated for the local concerns of Ireland, and it still retained with great jealousy a certain control over the power of the purse." (See Lecky's History of England in the Eighteenth Century, III., pp. 339-342.) (See also Ibid., IV., pp. 430-432.)

When, in 1771 , Benjamin Franklin, who, four years 
later, when leaning on the Bar of the British House of Lords, was denounced in his own hearing by Lord Sandwich as the most mischievous and bitterest enemy England had ever known, visited Ireland, he was received in the Irish House of Commons with conspicuous respect and honour. "I supposed," he writes, "I must go to the gallery, when the Speaker stood up and acquainted the House that he understood there was in town an American gentieman of (he was pleased to say) distinguished character and merit," and he asked that Franklin should be admitted to sit among them, which was unanimously granted. (Franklin's Works, VII., pp. 557-558.) Franklin has recorded his impressions of the Irish Patriot Party and of their attitude to America. "I found them," he said, " disposed to be friends of America, in which I endeavoured to confirm them with the expectation that our growing weight might in turn be thrown into one scale, and, by joining our interests with theirs, a more equitable treatment from this nation (Lingland) might be obtained for themselves as well as for us."* The cause of Ireland was, indeed, identical with the cause of America. 'The treatise of Molyneux was the text-book of Irish liberty. The assertion of Blackstone in his Commentaries, published in 1765 , the year of the passing of the Stamp Act, of the right of the British Parliament to bind Ireland by her laws without restriction or qualification, applied with equal if not with greater force to America. "It was plain to demonstration," writes Mr. Lecky, "that if the English Government could establish its right to tax the Colonies without their consent, it must possess

* Lecky's History of England in the Eighteenth Century, IV., pp. $434-435$. 
a similar power in Ireland."* Lord Harcourt; who had succeeded in attaching to his Government by the methods I have described every man who possessed considerable Parliamentary influence, was well aware that in the Irish Legislature the universal feeling of the country on the American question would be only feebly represented. He knew, however, that the Irish Patriot body were acting in union on this subject with the Opposition in the English Parliament, and that the troubles in America must, on the meeting of the Irish Parliament, be quickly the subject of discussion. He accordingly introduced the matter in the Speech from the Throne in October, 1775, by noticing the rebellion existing in America and by complimenting Ireland on her good behaviour. "I saw," he wrote to the British Cabinet, " the moment approaching when this important. question would have been pressed upon me by the Opposition to the King's Government in this country, who were daily gaining strength upon this ground with such advantages that I should have had great difficulty in resisting it." An address was at once drawn up in reply to the Speech from the Throne inviting the House of Commons to assure the King " that while his Government was disturbed by a rebellion of which they heard with abhorrence and felt with indignation, they would themselves be ever ready to show the world their devoted attachment to his sacred person."

An amendment moved by Mr. Ponsonby, strongly urging the necessity of " conciliatory and healing measures for the removal of the discontent which prevails in the Colonies," was defeated by 92 to 52 , and an amendment expunging the words which stigmatised the conduct of the Americans by 90 to 54, and the original

$$
\text { *Lecky, IV., p. } 432 .
$$


Address was carried. The discussion lasted without interruption till the evening following, and the Irish cause was openly identified with the American in speeches which the Lord Lieutenant considered to be "of great violence." Mr. Daly said that if America was beaten, 30,000 English swords would impose the Irish taxes, while Mr. Hussey Burgh declared that England meant to reduce her dependencies to slavery. Shortly after the Address had been passed, the House of Commons agreed by 103 to 58 to the proposal of the Government to permit 4,000 of the troops who were appointed by Statute to remain in Ireland for its defence to be withdrawn for active service in America as "armed negotiators "-a description of these forces by Flood which was long remembered. The absence on occasions of such importance of more than half the Members of the House of Commons is very significant, and may well be ascribed to the American sympathies of many members who owed their seats to great borough owners in alliance with the Government, and who were therefore precluded, according to the usual code of Parliamentary honour, from voting against the Minister.*

The methods by which the votes in favour of the English Government on the American question in the Irish House of Commons were secured when a general election was imminent may be surmised by a letter from Sir John Blaquiere to Mr. Robinson, the Secretary to the Treasury : "You must by pension or place sink a sum of not less than $£ 9,000$ per annum, exclusive of the provision that may be found requisite for rewarding and indemnifying those who are connected by office with His Majesty's Administration.

* Lecky's History of England in the Eighteenth Century, IV., pp 436-439. Froude's English in Ircland. II., pp. I42-I 44. 
... There are several gentlemen who, holding not a shilling under the Crown, have assisted or are now engaged to support the measures of the Government upon expectation given them of a suitable provision at the end of this Session." A step, to which frequent reference has been made, was, moreover, taken, which, in England, Mr. Lecky thinks, would probably have been followed by an impeachment. Eighteen peers were created in a single day, and seven barons and five viscounts were, at the same time, raised a step in the peerage. The terms of the bargain were well known to be an engagement to support the Government by their votes in the House of Lords, and by their substitutes and their influence in the House of Commons. Four baronets were also made about the same time for corrupt Parliamentary services. Having remained in office till after the General Election of 1776 , Lord Harcourt retired from the Irish Government in November of that year.

* I,ecky's History of England in the Eightecnth Century, IV., p. 440. † İit?., p. 44I. 
XII.

\section{THE IRISH PARLIAMEN'T AND PRESSURE FROM WITHOUT.}

DURING the "sinister" régime of Lord Harcourt in Ireland and that of his successor, Lord Buckinghamshire, the country was sunk in the lowest depth of wretchedness, and national bankruptcy was imminent. The National Debt amounted to one million sterling, while the nation was burdened with life annuities of $\delta^{6}$ per cent. for the sum of $f_{444}, 000$; the pension list had risen between March, 1773, and September, I777, from $£ 79,099$ to $f^{89,095}$; the establishment was loaded with sinecures such as the Mastership of the Rolls, the Chancellorship of the Exchequer, the three Vice-Chancellorships, to which enormous salaries were attached, and which, with one exception, Mr. Flood's Vice-Chancellorship, was filled by English absentee politicians. $f_{600,000}$ per annum went out of the country to absentee landlords. To crown all, the direct legislation of the British Parliament, arowedly contrived to hinder the development of Irish trade and manufactures, had, despite the despairing efforts of the Irish Parliament to modify its effects, laid the country prostrate. The War of the American Independence had closed one of the chief markets for Irish linens, while the provisions trade was annihilated by an embargo on the exports of provisions from Ireland. The rupture, moreover, with France inflicted dreadful financial injury on Ireland, for one of the effects of the 
Laws of the British Parliament restricting Irish commerce with Great Britain and her Colonies had been to establish a close commercial connection between Ireland and France (Lecky's History of England in the Eighteenth Century, IV., pp. 44I-442). At every opportunity great numbers were flying across the sea, and the extension of pasture, which diminished the price of labour, raised the price of bread. The coasts were threatened on every side by enemy ships of the line, which insulted the British flag, captured or destroyed vessels in the passage between England and Ireland, and threatened a descent upon the country, which was wholly unprotected. Such being the position of affairs in Ireland, the struggle between Great Britain and the American Colonies was watched with intense interest in Ireland, from the fact that the analogies between the American and the Irish questions were, as we have seen, very close. Lord Townshend, who, during his Viceroyalty, had repeatedly and vainly urged the British Cabinet to take measures for liberating Ireland from the commercial restraints imposed on her by British Parliament through the influence of selfish and rapacious English traders, speaking in the English House of Lords, thus contrasted Ireland with America, and foretold the consequences of refusal to remove from Ireland the trade shackles imposed upon her: "The Irish, he said, were patient under misery which might have driven a wiser people into madness. The Americans were rebellious in the midst of plenty and prosperity. Ireland, he declared, perishing in fetters which had chained her industry, had petitioned humbly for partial release, and England had answered insolently, 'Break your chains if you can.' The Americans had leagued themselves with England's inveterate enemy, for her 
total destruction. 'To them England had said, "You shall be free, you shall pay no taxes, we will interfere with you no more, remain with us on your own terms.' If these replies were persisted in, then the Irish, when peace was made, would emigrate to a land where honest labour would receive its due reward. While the war continued they would be held down by force, and at any moment they might refuse after all either to buy manufactures or export their own produce, and fleets and armies would preach to them in vain." (Froude's English in Ireland, II., pp. 238-239).

Lord Buckinghamhsire on his appointment to the Lord Lieutenancy had little experience in public affairs, but had filled some years previously the position of British Ambassador at the Russian Court. He selected as his Chief Secretary, at a most difficult and critical time in the relations between Great Britain and Ireland, whose delicacy was enhanced by a war of enormous magnitude, in which England was fighting for her existence, a gentleman who is thus described by one who knew him. "Posterity," he writes, "will hardly" believe that at a juncture so critical and alarming the Cabinet should not have insisted on the nomination of the Secretary as well as the Viceroy. But the choice was left to Lord Buckinghamshire. And what opinion he formed of the difficulties he was to encounter in the Irish Parliament may be gathered from the person he selected-a worthy man undoubtedly-Mr. Richard Heron, his law agent, and supervisor, I believe, of his estates. Now, let the reader conceive an antique scrivener or laborious conveyancer from Gray's Inn transplanted at once to such a scene as Ireland presented at that time! When he arrived there, what was expected 
from him or what were the duties, even in part, he was to perform? To raise the manufactures, the revenue, the commerce of the country, all drooping, all withered! To combat the prejudices of the mercantile interests in England, to soothe clamours at home, to reconcile the minds of men to a desolating civil war with America, to balance parties, to manage the leaders of the House of Commons, and win the high debate. Alas! good man, he was not only inadequate to ail this, but to any part of it, nor was he to be blamed. Neither his species of knowledge nor habits of life were in the slightest degree assimilated to his situation. What right had the British Cabinet to complain when they committed the interests of both countries in truth to such a well-meaning but inefficient personage ?"**

The Parliament which had been elected when the Viceroyalty of Harcourt was drawing to an end met for the first time in the autumn of 1776 . The methods by which Lord Harcourt had prevailed in securing a majority in that Parliament, which was destined for the establishment of the Constitution of 1782 , have been already sketched, and for the first few weeks of its sittings matters proceeded smoothly, and public attention was directed more to the developments of the American War than to purely domestic afiairs, more especially as the realities of warfare had been brought home very painfully to the people of Ireland by the danger of enemy raids upon her coasts. In a few months, however, this lull was broken, and the year r 778 was one of the most memorable in the constitutional history of Ireland, as it witnessed the first and most substantial relaxation of the laws in restraint of trade, the first important modification of the Penal Code, and the rise of the Irish Volunteer Movement. These great events

* Hardy's Life of Charlemont, I., pp. 366-367. 
must be regarded as closely associated and allied with each other. 'The demand for the removal of galling trade restrictions, the protest against the infliction of this grievous wrong in the interests of Great Britain and to the prejudice of Ireland, to be effective should have been made by a united people, and not by a privileged section, who, while complaining of injustice and violation of national rights, were themselves inflicting the most serious political and civil lisabilities on the vast majority of their own fellow-countrymen. The Volunteer Movement, moreover, being a movement of an extra Parliamentary character and claiming for its support public opinion, found that support not merely from: the Protestant but from the Catholic population of Ireland. The epoch in Irish history inaugurated in 1778 owed its existence to the spirit of resistance to injustice, and the determination to abate all wrongs which animates an entire nation, and is not the perquisite of any mere section of the community. On the $7^{\text {th }}$ February, 1778, Mr. Grattan moved in the House of Commons an address to the Crown that the condition of Ireland was no longer endurable. He laid stress on the lavish expenditure on a Military establishment, while the country was undefended, and its coasts insulted by enemy ships. The sinecures and the pension list were subjects of strongest reprobation. The motion, as might have been expected in an assembly whose composition was so thoroughly affected by Harcourt's corruption, was defeated by 143 to 66 , but the Lord Lieutenant in his letters to the Cabinet and to the Prime Minister states very plainly that the Parliamentary majority on this occasion was fai from representing the feelings of the country. The Lord Lieutenant stated that the supporters of the Govern- 
ment after this division expressed to him their hope that the privileges which were to be granted through the medium of Lord Carlisle, then on a mission to America to the American Colonies in revolt, would be extended to Ireland, and that the restrictions on Irish trade would be relaxed or abolished. (Froude's English in Ireland, II., pp. 225-226.) Lord North cordially adopted the view of Lord Buckinghamshire, that an enlargement of the trade of Ireland had become absolutely necessary for the support of the country, and Lord Nugent brought the question of the relaxation of the Irish Commercial Code before the English Parliament in April, 1778. The propositions that Ireland, with the exception of the restrictions on wool and the woollen manufacture, might send all her products to the English settlements and plantations, and might receive those of the Colonies, with the exception of tobacco, in return, without their first being unladen in England, and to repeal a prohibitory duty which excluded from England cotton yarn made in Ireland, were at first well received as being founded on justice and a liberal policy required by the circumstances of the time. Subsequently, however, the jealousy of English manufacturers and traders was so strongly expressed, and so much influenced the conduct of many of the representatives of those interests in Parliament, that in the Bill giving effect to the propositions it was thought necessary to give up most of the advantages originally intended for Ireland. "Vessels made in Ireland were no doubt henceforth to be considered British built, and were to be entitled to receive the bounties in fisheries of every kind, but the Irish were forbidden absolutely to export to the Colonies wool, woollen and cotton manufactures, hats, glass, hops, gunpowder, and coals. They 
were forbidden to export iron or iron wares till the Irish Parliament had inmosed a prescribed duty upon them. They were obliged in like manner to charge duties and taxes on all their exported manufactures equivalent to those paid on similar articles of British fabric, and they were still forbidden to import goods direct from the Colonies. Cotton yarn homespun in Ireland might, however, now be imported into England free of duty I8 Geo. III., Ch. 55-56). The concession was plainly insufficient for the necessities of Ireland, and at a time when commerce with America was wholly suspended, it was almost nugatory. It marked, however, the gradual subversion of the old policy of restriction."* Edmund Burke, whose advocacy of the cause of Ireland on this occasion was the subject of severe stricture by his constituency-the commercial city of Bristol-in letters in defence of his action says : "Is Ireland united to the Crown of Great Britain for no other purpose than that we should counteract the bounty of Providence in her favour, and in proportion as that bounty has been liberal that we are to regard it as an evil which is to be met with in every sort of corrective?" (Burke on Irish Affairs, edited by M. Arnold, p. Ior.) Again, "Ireland, having received no compensation, directly or indirectly, for any restraints on her trade, ought not in justice or in common honesty to be made subject to such restraints. I do not mean to impeach the rights of the Parliament of Great Britain to make laws for the trade of Ireland-I only speak of the laws it is right for Parliament to make." (Edmund Burke on Irish Affairs, edited by M. Arnold, p. III.)

The wretched condition of the finances (the Treasury

$$
\text { *Lecky, IV., pp. 447-45I. }
$$


was literally empty) - the Government that had obtained a loan of $£_{20,000}$ from La Touche's Bank, on further application were told by the heads of that Bank " that it was not in their power to lend, though very much in their inclination ";* the corrupt disposal of patronage, the refusal of the English Parliament to grant that commercial freedom which was essential to Irish prosperity, and, above all, the example of America, had engendered a strong aspiration towards legislative independence, and a conviction that it could only be obtained with the hearty goodwill of the Catholics. Sir George Savile carried through the British Parliament in 1778 the first Roman Catholic Relief Act which was passed in England. The penalties which were then repealed were imposed in 1700. They were the perpetual imprisonment of priests for officiating in the services of their Church, the forfeiture of the estates of Roman Catholics being educated abroad in favour of the next Protestant heir, and the prohibition to acquire land by purchase. $\dagger$ This Act, which passed unanimously through the Parliament, gave rise to the riots of 1780 which were associated with the name of Lord George Gordon.t Such legislation presented an object lesson to the Irish Parliament if inclined to modify the disqualifications imposed by the Irish Penal Code. The Irish Catholics had been uniformly loyal to the Crown, despite the horrible grievances under which they suffered. In March, 1778, when the Catholic Committee had presented to Lord Buckinghamshire a statement of the civil and political disabilities from which they sought relief, he was amazed at the comprehensive character of iheir demands, which, he informed the British Cabinet, amounted to a repeal almost of the whole of the Penal Laws. $\S$ The substance of the Catholic demands was that

\footnotetext{
* MacNevin's History of the Irish Volunteers, p. 67.

† I 8 Geo. III., c. 60.

* May's Constitutional History, III., pp. 96-99.

$\S$ Froude, II., p. 226.
} 
no person who had taken the Oath of Allegiance in its latest form, in accordance with a Statute of 1774 and a Form of Declaration thereby prescribed, renouncing allegiance to the Stuarts and denying the temporal and civil jurisdiction of the Pope within the Realm, should be counted a Papist according to the meaning of the Popery Acts. The Lord I ieutenant, as the result of enquiries then made, came to the conclusion that, although a relaxation of the Penal Laws was desirable, the present time was unfavourable for its proposal. In the summer, however, Lord North, who was fully aware of the disappointment and discontent which the failure of the total repeal of the Commercial Code was certain to produce, hoped that a relaxation of the Penal Laws might prevail to soothe an irritation which was highly justifiable. When the Lord Lieutenant wrote that, in consequence of the recent measures in favour of Roman Catholics in the English House of Commons, "measures of a similar tendency were in agitation in Ireland," the Viceroy was directed by Lord North, who, in the debate on Irish commerce, had taken occasion to say a few sympathising words in favour of the Catholics, "to urge the friends of the Government to forward some measure of expedient relief." The Bill was introduced by Mr. Luke Gardiner, afterwards Lord Mountjoy, who fell in the battle of Vinegar Hill in 1798 . His proposal was to repeal the gavelling clauses of the Act of Anne, to allow the property of Catholics to descend unbroken, to take from the eldest son the power of making his father tenant for life by effecting concessions to enable Catholics to purchase freehold properiy, and to relieve them from the vexatious limitations on their leases which had led so many of the larger tenants to affect to be Protestants. 
An amendment to withhold from Catholics the right of buying freeholds, and to enable them instead to take leases for 999 years, was carried after a long debate by a majority of three-II I to ro8. A clause proposed by Sir Edward Newenham for relieving Presbyterians from the Sacramental Test was added to the Bill. That clause was, however, struck out by the English Privy Council, and the enemies of the Catholics hoped that the Irish House of Commons would be so exasperated at the mutilation that they would throw out the whole measure. They acted, however, more wisely, and the first great Relief Bill for the Irish Catholics was carried through the Commons by 127 to 89 , through the Lords by 44 to 28 .* This great remedial measure was a source of genuine joy to Henry Grattan, whose first principle was that " the Irish Protestant would never be free till the Irish Catholic had ceased to be a slave." Burke, in a letter written to the Speaker of the Irish House of Commons in reference to this measure, says: "The Irish House of Commons has done itself infinite honour..... You are now beginning to have a country, and I am convinced that when that thing called a country is once formed in Ireland quite other things will be done than were done whilst the zeal of men was turned to the safety of a party, and whilst they thought its interests provided for the distress and destruction of everything else." $\dagger$

* Lecky's History of England in the Eighteenth Century, IV., pp. 477-479. Froude's English in Ireland, II.. pp. 232-236.

† Lecky, IV., pp. 479-480. 
XIII.

\section{THE IRISH PARLIAMENT AS AFFECTED BY}

\section{THE VOLUNTEER MOVEMENT.}

Mr. Grattan, who had a genius for epigram, in moving in the Irish House of Commons on April 16th, 1782, the declaration of Irish rights and grievances, tersely described the methods by which Irish Legislative Independence had been secured, and sketched accurately the rise and progress of the Volunteer Movement which had been so powerful a factor in that great achievement. He narrated the career of the Irish nation from " injuries to arms and from arms to liberty," till the whole faculty of the nation was braced up to the act of her own deliverance. The country, reduced by the circumstances I have endeavoured to state to a condition of abject poverty artificially produced, was left undefended from foreign invasion. The English fleet was occupied elsewhere and the Irish coast was unprotected. It was said that little more than a third part of the 12,000 men who were considered necessary for the defence of their country were there, and they were concentrated chiefly in one or two encampments.* The Government were quite unable to discharge the primary duty of protecting the country. When official information came that an invasion of Belfast by the French was imminent, application was

* Lecky's History of England in the Eighteenth Centur', IV oj p. $4^{82}$. 
made for troops for its defence. The reply to that application, embodied in the letter of Sir Richard Heron, the Chief Secretary and former estate agent of the feeble Lord Lieutenant, was the direct cause of the Irish Volunteer Movement, and its effect was so momentous that it may well be reproduced in its entirety. The letter was addressed to the "Sovereign" of Belfast, and is as follows :-

SIR,

$$
\begin{aligned}
& \text { "Dubrin Castre, } \\
& \text { August 14Th, I778. }
\end{aligned}
$$

My Lord Licutenant, having received information that there is reason to apprehend that three or four privateers in company may in a few days make attempts on the northern coasts of this kingdom, by His Excellency's command I give you the earliest account thereof in order that there may be a careful watch, and inmediate intelligence given to the inhabitants of Belfast in case any party from such ships should attempt to land. The greatest part of the troops being encamped near Clonmel and Kinsale, His Excellency can at present send no further aid to Belfast than a troop or two of horse, or part of a company of invalids, and His Excellency desires you will acquaint him by express whether a troop or two of horse can be properly accommorlated in Belfast, sulong as it may be proper to continue them in that town, in addition to the two troops now there.

$$
\text { I have, etc., }
$$

RICHARD HERON." *

Under these circumstances the people of Ireland, at a time when a pauper Government was unable, in the words of Dr. MacNevin, "to furnish the country with a hundred men," determined to defend themselves. The Belfast men, who had eighteen years previously proved their mettle under Lord Charlemont, when Thurot had landed at Carrickfergus, and were thanked for their services by the Lord Lieutenant of the day, rushed to arms and formed associations for defence against the foreign enemy. Their example was quickly followed throughout the length and breadth of the land. Military discipline was acquired under the instruction of

$$
\text { * MacNerin's Volunteers, p. ;2. }
$$


seasoned veterans in the American campaigns. The Volunteers chose their own officers, who were generally the leading noblemen and the gentlemen of their respective localities. They submitted to the most rigorous military discipline. Huge sums were subscribed for the various munitions of warfare. The Roman Catholics, who were not yet enrolled, contributed most liberally to the funds of the Association-those of the County of Limerick alone subscribed $\AA_{800}$-and their enthusiasm was undamped by the fact that on the 12 th July, Orange Volunteer Companies paraded in their uniform with Orange cockades and fired three volleys in commemoration of the Battle of the Boyne. Meetings were held in every county, and resolutions adopted enthusiastically for the raising of Volunteer Companies.*

Lord Buckinghamshire, the Lord Lieutenant of Ireland, dic not view the rise of the Volunteer Movement with any particular favour. He writes to the English Cabinet on I 2 th December, I778, explaining that the conditions of the finances had rendered it impossible to raise troops for the protection of the country, and that the idea then was among the people that they must defend themselves. He could not, he said, comply with the request made to him to supply them with arms and ammunition-such associations, however justifiable in extreme danger, not being allowable by law-but he did not attempt to suppress them, and he now finds that they are spreading into the interior of the kingdom. In another letter Buckinghamshire writes that discouragement has been given on his part as far as might be without offence at a crisis when the aim and goodwill of every individual

\footnotetext{
* Lecky's History of England in the Eighteenth Century, IV.,pp $48_{4}-485$.
} 
might have been wanting for the detence of the State, while in the interior and remote parts of Ireland the mode of "suppressing" the Volunteers would have been “difficult and delicate.”* In April, 1579, he writes: " The Grand Juries represented that the fields and highways were filled with crowds of wretched beings, hal naked and starving; that foreign markets were closed to them, and they besought the King to interfere in their favour for the removal of the restrictions on Irish trade." In February, 1779, the Sheriffs of Dublin informed the Lord Lieutenant that in that city alone more than 19,000 persons connected with the weaving trade, besides many other poor, were on the brink of starvation, and that nothing but an extension of trade and a free export of their manufactures could save them. $\dagger$ At last, as Lord Townshend had foreseen, the advice of Swift, given half a century before, was taken. On April 26th, 1779, a great meeting was held at the Tholsel in Dublin, at which all present pledged themselves to exclude from the Irish markets every article of British manufacture which could be produced at home. The Lord Lieutenant was anxious to prosecute the organisers of the meeting, but the Law Officers of the Crown deprecated the taking of such a course, which would have led to an insurrection.f The Volunteers themselves, to whom the Viceroy had eventually in September, 1779, upon the urgent advice of the Privy Council, given 16,000 stands of arms, originally designed for a militia which there was no money to support, favoured Irish manufacturers by clothing their regiments and troops in materials of Irish production, and by the passing of resolutions promising assistance

* Lecky's History of England in the Eighteenth Century, IV., p. 486.

$\dagger$ Lecky, IV., p. 487 .

+ Froude's English in Ireland, II., pp. 234-240. 
to the non-importation movement, and urging the extension of the commerce of Ireland. The Lord Lieutenant, in his letter to the British Cabinet describing the Tholsel meeting, warned them that if the session of the English Parliament closed without some favour to Ireland, he looked forward to a formidable opposition when the Irish Parliament met.* Lord Weymouth, on the part of the Cabinet, admitted the very serious character of the nonimportation movement, but advised the Viceroy to be conciliatory in manner, to express the sympathy of the King with the sufferers from the prevailing distress, and obtain the opinions of prominent persons on the causes of the impoverished condition of the country to be laid before the Cabinet. 'The Lord Lieutenant accordingly requested the Lord Chancellor (Lord Lifford), the Lord Chief Justice (Lord Annaly), the Speaker (Mir. Pery), the Prime Serjeant (Mr. Hussey Burgh), the Provost (Mr. HelyHutchinson, and Sir Lucius O'Brien to state their views, which were given in writing with great detail and elaboration, and when presented in July, 1779, embodied the unanimous conclusion that the removal of the trade restrictions was essential to the very existence of the Irish people.t The Lord Lieutenant did not fail to apprise the Cabinet of the effect of the Volunteer Movement in relation to the economical condition of the country. Writing in May, 1779, he speaks of the insinuations which are daily circulated in the public prints that the idea of the number of the Volunteers may conduce to the attainment of political advantages for their country. $t$ In the same month a letter from Lord Weymouth on behalf of the Cabinet, directing Lord Buckinghamshire

* Lecky, IV., pp. $4^{87-488 . ~}$

Froude's English in Ireland, II., pp. 240-24I.

* Lecky, IV., p. ${ }^{\prime} 88$. 
to prevent the Volunteers from assembling and to take their arms from them, elicited the immediate reply that it was too late for such steps, which in the absence of a militia were impossible ; that the movement had spread as if the whole country had in it a purpose already prepared; that to interfere there must be a British Army, and there were not 3,000 British soldiers in the island.* The loyalty of the Volunteers and their devotion to the connection between England and Ireland were regarded as beyond question, and there can be no doubt whatever that the existence of this organisation prevented in August, 1779, a most formidable descent on the Irish western coast. $\uparrow$ In the words of Mr. Lecky, "a sincere loyalty to the Crown and a firm resolution to defend the country from invasion were blended with a resolute determination to maintain a distinctively Irish policy" (Lecky's History of England in the Eighteenth Century, IV., pp. 495-496).

The Session of the Irish Parliament from October 12, I779, till September 2, 1780, was one of the most prolonged and important Parliamentary Sessions ever held. The speech from the Throne was designedly vague and colourless. An amendment to the Address moved by Grattan, that it was not by temporary expedients, but by a free export, that the nation was now to be saved from impending ruin, was carried, with an alteration at the instance of Flood, who insisted that the amendment should go to Free Trade. Votes thanking the Volunteers for their spirited and necessary exertions in the defence of their country were carried unanimously in the House of Commons, and with two dissentient voices in the House of Peers. The reply from the King of Ist

* Froude's English in Ireland, 11., pn. 251-252.

† Froulic, II., pp. 253-254. 
November, that he would be always ready to concur in " measures which on mature consideration should be thought conducive to the general welfare of all his subjects," produced great discontent, and was interpreted as a refusal to entertain the policy of free trade. The $4^{\text {th }}$ November, which was celebrated as the birthday of William III., was the occasion of a Volunteer demonstration in front of Parliament House and round the statue of William III., which was hung on all sides with very significant emblems, " The Volunteers of Ireland," "A Short Money Bill," while two cannon bore the label "Free Trade or This." The populace, who were incensed by a remark of Scott, the Attorney-General, in reference to the Volunteer Demonstration, as to whether Parliament existed to register the pleasure of the Volunteers, assailed his house, went in search of him to the Four Courts, and finding that he had taken refuge in Dublin Castle, went to College Green and compelled members as they were about to enter Parliament House to swear that they would vote for Free Trade and a Short Money Bill. The military were summoned to disperse the crowd, but the Lord Mayor of Dublin in terror refused to order them to act. The House of Commons, by a resolution on the day following, condemned the assembling of mobs to coerce debate, and the Lord Mayor and Sheriff were summoned to the bar to be reprimanded for their cowardice. A motion by Grattan, that it was inexpedient in the presence of so much general poverty to grant new taxes, was carried by 170 votes to 47 , and a Six Months' Money Bill was carried by 138 to 100. It was on this occasion that Hussey Burgh used the memorable words in reply to a statement that Ireland was at peace : "Talk not to me of peace, it is smothered war. 
England has sown her laws in dragon's teeth, and they have sprung up in armed men." A few days later he sent in his resignation of the position of Prime Serjeant. " The gates of promotion," said Grattan, " are shut, and the gates of glory are opened."*

In December, 1779, the repeal of the Sacramental Test, which had been added as a clause to the Catholic Relief Bill of 1778 , and had been eliminated by the English Privy Council, was brought in as a distinct measure, and, having passed the House of Commons, was returned unchanged by the Irish and English Privy Councils, and became law. The placing of this measure on the Statute Book was a distinct acknowledgment by the English Government of the power of the Presbyterians, which had been enormously augmented by the Volunteer Movement. There is little doubt that the failure of the efforts for the repeal of the Test Act in 1778 was largely due to the fact that the Presbyterians were as a body open and avowed sympathisers with the American Colonies in their struggle for independence.

The proceedings of the Irish Parliament, which were beyond all doubt approved by the Irish nation as a whole, strengthened the Lord Lieutenant in his urgent request for the removal of the commercial restrictions - a project to which Lord North was very favourable, but refrained from accomplishing through the pressure and terrorism of the English trade interests. At the close of 1779 and the beginning of 1780 a series of measures was carried in England wholly repealing the Acts which prohibited the Irish from exporting their woollen manufactures and their glass, and the great trade

* Lecky's History of England in the Eighteenth Century, IV., pp. 498-499. Froude's English in Ireland, II., pp. 256-264. 
of the Colonies was freely thrown open to them on the sole condition that duties equal to those paid in British ports be imposed by the Irish Parliament on the imports and exports of Ireland.* The Heads of a Bill giving Irish judges the security of tenure enjoyed by English judges under the provisions of the Act of Settlement were sent over to England, but rejected by the Privy Council, although a measure of this nature had been promised by Lord Townshend many vears previously in his first speech from the Throne. The Heads of a Habeas Corpus Bill were likewise not returned by the English Privy Council.t

The Lord Lieutenant very clearly saw that the abolition of the restrictions on Irish trade by no means completed the programme of the Volunteers. In 1780 the detached bands were organised into a regular army, and consolidated into an efficient body under the command of officers, Lord Charlemont himself becoming the Commander-in-Chief. It was clear that the peop!e were determined to secure the extension to Ireland of all the popular rights and privileges guaranteed to England by the Revolution of r 688 and the legislation resulting therefrom. To this great and inspiring movement the Lord Lieutenant was only able to offer a resistance based on Parliamentary corruption. "Beyond a certain line," he writes, in February, 1780, to Lord Hillsborough, who had succeeded Lord Weymouth in the Secretaryship of State, "you cannot press, for the intended conduct of independent gentlemen and even positive assurances may not be able to resist popular clamour. Upon the whole, it is my private opinion

* Lecky, IV., pp. 500-50I.

†Lecky, IV., p. 504. Froude, II., p. 200. 
that, barring insurrection, or something nearly resembling it, I shall go through the business of the Session with success."* He tells Lord Hillsborough that he has already secured his majority, and could count on the support of I 54 out of the 300 members of the House of Commons, and of these 154,78 had already places or pensions. $\dagger$ On March I, 1780 , in discussion on a resolution expressing gratitude for the repeal of the trade laws, Mr. Grattan, with exquisite directness of language, announced that the wants and wishes of the people had not yet been satisfied. "Poynings' Act," he said, " must be modified, and the Declaratory Act passed by the British Parliament, asserting the powers of that Parliament to make laws binding on Ireland, must be repealed." $f$ Grattan, subsequently, gave notice that he would move on the rigth April a declaration of rights, and Mr. Bushe on the 18 th April, the day before the time fixed for Grattan's motion, asked leave at a later period to bring in a Mutiny Bill, on the ground that the English Mutiny Bill did not extend to Ireland. This leave, which was opposed by the Government, was granted.§ Mr. Grattan's declaration of independence consisted of a series of resolutions which formed the basis of the Irish Constitution of 1782. They asserted that while the Crown of Ireland was inseparably annexed to that of Great Britain, no power on earth but the King, Lords and Commons of Ireland was competent to make laws for Ireland. After fifteen hours the debate was indefinitely adjourned. The Lord Lieutenant, however, thus records his impression of its effects : "It is with the utmost concern that I must acquaint your Lordship (Lord Hillsborough) that, although so many gentlemen expressed

* Froude, II., p. 274 ; Lecky,IV.pp. 502-503. †Lecky, IV., p. 505. † Froude, II., pp. 275-276.

$\S$ Froude, II., p. 278. 
their concern that the subject had been introduced, the sense of the House against the obligation of any Statutes of the Parliament of Great Britain within this kingdom is represented to me to have been almost universal." When Bushe introduced his motion proposing the Heads of a Mutiny Bill, Sir Richard Heron, the Chief Secretary, moved that it should be postponed for a fortnight, in orcier that instructions should be received from England. That motion was carried by 146 to $75 . \dagger$ Bushe's Bill, with an additional clause moved by Foster, to the effiect that the Army should be regulated by such laws as the King has made or may make not extending to life or limb, passed through the House of Commons and through the Privy Council, and was transmitted to England. It was, however, returned from the English Privy Council, altered by the omission of the words limiting its duration, altered in other words into a perpetual Mutiny Bill. A motion for restoring the original words was defeated by 114 to 62 , and thus the government of the Army in Ireland was placed beyond Parliamentary control. The Supply Bill was also returned altered, the English Privy Council having refused to sanction a prohibition duty against British loaf sugar, and the Bill thus altered passed through the Irish Parliament.f Three bodies of Dublin Volunteers passed resolutions denouncing the conduct of the majority in Parliament, which they ordered to be published in the papers. The Session ended on September 2nd, and nearly the last act of the House of Commons was to censure the Volunteer Resolutions as seditious and libellous, and to call upon the Lord Lieutenant to institute

* Lecky, IV., pp. 508-510.

$\ddagger$ Lecky', IV., pp. 5II-514. Froude, II., pp. 281-287 
prosecutions against the printers and publishers.* The securing by the Lord Lieutenant of a Parliamentary majority was an achievement for which the price paid must be regarded as excessive. Immediately after the conclusion of the Session he wrote to the English Cabinet recommending eight members of the House of Commons for peerages, thirteen peers for advancement in the peerage, five appointments to the Privy Council, seventeen persons for civil pensions, and several others for favours of other kinds. The English Ministry refused at first to acknowledge the claims of any one of the persons whose names appeared in the Viceroy's detestable list. At last five peerages were granted, and eleven steps in the peerage and many places and pensions. "I had not," said the humiliated Lord Lieutenant, " contracted any absolute engagements of recommendation either to peerage or pension till difficulties arose which necessarily occasioned so much and such forcibly communicated anxiety to His Majesty's Cabinet that I must have been culpable in neglecting any possible means of securing a majority in the House of Commons." $\uparrow$ The letters of the patriots who were cheated out of the bribes promised for votes given against the interests of their country are extant. One of the disappointed legislators, Sir Henry Cavendish, actually challenged Lord Buckinghamshire to a duel.f A period was put to Lord Buckinghamshire's disgraceful tenure of the office of Lord Lieutenant very shortly after the end of this Session of the Irish Parliament, whose history was thus sketched by Edmund Burke himself, speaking in 1780 : "Forty thousand men were raised and disciplined without commission from the Crown. Two illegal

\footnotetext{
* Froude, II., pp. 286-290. Lecky, IV., pp. 512-5I4.

$\dagger$ Lecky, IV., pp. 5I5-5I6. †Froude, II., pp. 292-294.
} 
armies were seen with banners displayed at the same time and in the same country. No executive magistrate, no judicature in Ireland, would acknowledge the legality of the Army which bore the King's commission, and no law or appearance of law authorised the Army (of Volunteers) commissioned by itself. In this unexampled state of things, which the least error, the least trespass on the right or left, would have hurried down the precipice into an abyss of blood and confusion, the people of Ireland demand a freedom of trade with arms in their hands. They interdict all commerce between the two nations. They deny all new supply in the House of Commons, although in time of war. They stint the grant of the old revenue given for two years (the Irish Parliament had not annual but biennial sessions) to all the King's predecessors to six months. The British Parliament in a former Session (1778), frightened into a limited concession by the menaces of Ireland, frightened out of it by the menaces of England, was now frightened back again, and made a universal surrender of all that had been thought the peculiar reserved uncommunicable rights of England - the exclusive commerce of America, of Africa, of the West Indies, all the enumerations of the Acts of Navigation, all the manufactures-iron, glass-even the last pledge of jealousy and pride, the interest hid in the secret of our hearts, the inveterate prejudice moulded into the constitution of our frame, even the sacred fleece itself all went together (in 1779). No reserve, no exception, no debate, no discussion. A sudden light broke in upon us all. It broke in not through well-curtained and well-disposed windows, but through flaws and breaches, through the yawning chasms of our-ruin. We were taught wisdom by humiliation. No town in 
England presumed to have a prejudice or dared to mutter a petition. What was more, the whole Parliament of England, which retained authority for nothing but surrender, was despoiled of every shadow of its superintendence. It was without any qualification denied in theory as it had been trampled upon in practice. This scene of shame and disgrace has, in a measure, whilst I am speaking, encied by the perpetual establishment of a military power in the dominions of the Crown (the Irish Perpetual Mutiny Act) without the consent of the British Legislature, contrary to the policy of the Constitution, contrary to the declaration of rights, and by this your liberties are swept away along with your supreme authority-and both linked together from the beginning have, I am afraid, both together perished for ever." (Edmund Burke on Irish Affairs, edited by M. Arnold, pp. 130-131.) 


\section{XIV.}

\section{'THE TRIUMPH OF GRA'T'TAN AND THE}

\section{VOLUNTEERS.}

THE appointment to the Lord Lieutenancy in succession to Lord Buckinghamshire, with Sir R. Heron as his Chief Secretary, of Lord Carlisle, with Mr. Eden as his Chief Secretary, was calculated to generate well-founded hopes of a full concession of Irish demands, having reyard to a very recent incident in the careers of the new Lord Lieutenant and his Chief Secretary, and the admittedly analogous character of the Irish and the American Questions. Lord Carlisle and Mr. Eden, afterwards raised to the Peerage as Lord Auckland, were the two Commissioners sent out by the British Cabinet to America after the surrender of Burgoyne at Saratoga - the pretension to tax the Colonies having been totally abandoned by statute-with power to offer free trade, to offer seats in the British House of Commons if America wished to be represented there, to offer even in the name of England to share the debt which the Colonists had incurred in maintaining the war. The offer, however, now that France had entered into an alliance with America, which a few months previously would have been accepted with gratitude, came too late-Congress replied that if Great Britain desired to negotiate with America she must withdraw her fleets and armies and recognise American Independence.* Although Lord

* Froude, II., pp. 220-22I. 
Carlisle and Mr. Eden did their best to resist popular measures in Europe, their correspondence with the Cabinet, more especially the correspondence of Lord Carlisle, warning the Government against the folly of meeting the Irish claims with a definite refusal, shows how strongly they had been impressed by their American experience. Lord Carlisle informed the Cabinet repeatedly that Ireland could not be governed by English Laws. "It is beyond a doubt," he writes, " that the practicability of governing Ireland by English laws is become utterly visionary. It is with me equally beyond a doubt that Ireland may be well and happily governed by her own laws. It is, however, by no means so clear that if the present moment is neglected this country will not be driven into a state of confusion, the end of which no man can foresee or limit." (Lecky, IV., pp. 540-54r.) The policy of Lord Carlisle was as far as it was feasible in antagonism to the National Movement, whose strength and intensity he was quick in apprehending. He arrived in Dublin in December 1780 ; the Parliament was not to meet till October, $178 \mathrm{r}$. The Lord Lieutenant and his Secretary prepared to tread in the path of their predecessors by overbearing opposition in the accustomed way. The brother of Mr. Pery, the Speaker, was appointed to a Bishopric, while we find the Chief Secretary complaining of the want of a secret service fund, and imploring that the Lord Lieutenant should be allowed to draw the sum of $£ 3,000$ a year at least from the King's Privy Purse to be applied to His Majesty's service and the effective conduct of Government.* The Volunteers in the meanwhile increased and multiplied, and, of course, emphatically supported the popular

* Lecky, IV., pp. 5i9-520. Froude, II., pp. 311-313. 
demands. It has been computed that towards the close of 1781 they numbered no fewer than 80,000 men. When in September, 1781 , Ireland was again threatened with invasion on her southern coasts, the City of Cork being the principal objective, Lord Charlemont waited on Lord Carlisle and proposed that the Volunteers should act under the Commander-in-Chief of the Forces to assist the regular troops. It was computed that 15,000 men could be spared from Ulster for the defence of Munster. The offer was accepted in what Mr. Lecky calls grateful but guarded terms. The word "Volunteers " does not occur in his Excellency's reply. "I have ever," said the Lord Lieutenant, " placed the most unbounded confidence in the attachment and loyalty of all His Majesty's subjects in this kingdom to His Majesty's person and government, and I receive with particular pleasure these early and spirited offers of services of which I shall think it my duty to avail myself to the fullest extent if either the events of war or further intelligence should make it expedient to have recourse to them."*

The instructions given to the Lord Lieutenant for the guidance of the administration during the Session of Parliament which opened on the 9th October, 1781 , were to divert the Parliament from all constitutional questions and to oppose with all his power any attempt to carry a declaration of independence, the repeal of Poynings' Act, and the limitation of the Mutiny Act. The Lord Lieutenant wished in his speech to refer in special terms to the loyalty of the Volunteers. He was, however, restrained from so doing by the English Cabinet. The Address to the Throne from the House

*Lecky, IV., pp. 52I-524. MacNevin's Volunteers, p. I47. 
of Commons was accompanied with a vote of thanks to the Volunteers. A motion by Mr. FitzGibbon, that, before the thanks of the House were voted to the Volunteers, the censure passed on them at the close of the last Session should be read, was received with very great indignation as an effort to stir up forgotten controversies.* The Heads of a Habeas Corpus Bill were introduced and passed in all their stages. These Heads of a Bill were subsequently returned from England and became law.

A limitation of the Perpetual Mutiny Act, moved by Grattan, seconded by Flood, who was dismissed from the Privy Council and anticipated dismissal from the Vice-Chancellorship by resignation, was rejected by a large majority. $\dagger$ An address of sympathy with Great Britain on the occasion of the surrender of Lord Cornwallis was carried by 167 to 37 , although both Flood and Grattan urged in vain that it should include a demand for Irish Independence.f The Committee which Flood desired on the administration and working of Poynings' Law was rejected by 66 to 135 , but the Heads of a Bill introduced by Yelverton, restricting the Irish Privy Council to sending over to England the proceedings of the Irish Parliament without alteration, passed through all its stages, and had the warm recommendation of the Lord Lieutenant for its acceptance by the Irish and the English Privy Councils. $\oint$

The failure, however, of all attempts to repeal or modify Poynings' Law, and to abolish the usurped power of the British Parliament to legislate for Ireland,

\footnotetext{
* Froude, II., pp. 317-318.

†Froude, II., p. 321. Lecky, IV., pp. 524-526.

$\ddagger$ Lecky, IV., p. 527.

$\$$ Lecky, IV., pp. 528-529. Froude, II., 326-327.
} 
concentrated attention on the essentially corrupt and unrepresentative character of the Irish Parliament, and the urgent need of bringing pressure from without, the product of public opinion, to bear on that assembly. The Volunteers well knew that the achievement of Free Trade rendered the establishment of an unfettered Irish Parliament easily within their reach.

On December 21,1781 , the officers and delegates of the first Ulster Volunteer Regiment, commanded by Lord Charlemont, assembled to take into consideration the state of the country and the prospects of the national caluse. They invited the Volunteer Regiments of Ulster to assume the functions virtually abdicated by Parliament, and to send delegates to a Convention to be held in Dungannon on the $15^{\text {th }}$ February, 1782 , to deliberate on the alarming condition of public affairs. ${ }^{*}$ On the $15^{\text {th }}$ February, I 782 , the representatives of the regiments of Ulster-one hundred and forty-three Corps-marched to the Church at Dungannon, two and two, attired in their various uniforms and fully armed. The fact that five measures passed quite recently by the British Parliament were extended to Ireland gave a most powerful impetus to the work of the Convention (Lecky's History of England in the Eighteenth Century, IV., p. 540). They passed resolutions, as the representatives of 25,000 armed men, and in the truest sense a Parliament, declaring that the claim of any body of men other than the King, Lords and Commons of Ireland to make laws to bind that kingdom is unconstitutional, illegal, and a grievance ; in favour of Free Trade ; the independence of the Judges ; the freedom of Irish legislation from interference by the

\footnotetext{
* MacNevin's History of the Volunters, pp. I53-154. Leci'y, IV., p. 532 .
} 
Privy Councils of England and Ireland; an Annual Mutiny Bill-pledging themselves only to support those candidates who would seek a redress of those grievances; appointing an Executive Committee to act for the Ulster Volunteer Corps, and to call general meetings of the Province as occasion shall require; nine members of this Executive Committee to be a Committee in Dublin in order to communicate with other Volunteer Corps in the other Provinces. They passed, moreover, two memorable resolutions which had been drawn up by Grattan. They resolved that "We hold the right of private judgment in matters of religion to be equally sacred in others as in ourselves ; that as men, as Irishmen, as Christians and Protestants, we rejoice in the relaxation of the penal laws against our Roman Catholic fellow subjects, and that we conceive the measure to be fraught with the happiest consequences to the union and prosperity of the inhabitants of Ireland." All Ireland adopted these resolutions, and meetings were held in every county for their formal endorsement. The delegates of Munster, Connaught, and Leinster met in pursuance of the respective invitations of Lord Kingsborough, Lord Clanricarde, and Mr. Flood.* A motion, however, of Mr. Grattan in the Irish House of Commons on February 22, 1782, for an Address to the King declaring the rights of Ireland, was lost by a majority of 137 to 68 . His speech is memorable for the tribute to the work of the Irish Volunteers. "You have an immense force, the shape of much greater of different religions, but of one political faith, defending the Government. I say aiding the Civil power and pledged to

* MacNevin's History of the Volunters, pp. I54-I60. Lecky, IV., pp. 532-534. 
maintain the liberty of Ireland to the last drop of their blood. Who is this body, the Commons of Ireland, and you at the head of them? It is the property, it is the soul of the country armed; that self-armed association this age has beheld, posterity will admire, will wonder."*

The Lord Lieutenant well knew the trend of public opinion in Ireland. In reference to the discussion on Grattan's address to the King in February, 1782, enunciating the independence of the Irish Legislature, Lord Carlisle wrote- " I must not omit to inform your Lordship that through the whole course of the debate the principle of Ireland not being bound by Acts of the British Legislature was most strenuously supported by every man who spoke on either side, even by those the most zealous in support of the Government, except only the Attorney-General, who, duly respecting his official situation, avoided declaring his opinion on the question of law, though repeatedly and urgently called upon by the Opposition." $†$

The Irish Parliament was adjourned for a month on March 14th. Before the separation, Grattan moved that a summons be issued by the Speaker ordering Members to attend on April 16th, the day following the Easter recess, as they tender the rights of the Irish Parliament. A few days after the adjournment of the Irish Parliament, Lord Carlisle, writing to the British Cabinet, as represented by Lord Hillsborough, bore a very striking testimony to the increasing influence of public opinion on the Irish Parliament. On March 28th, he writes : "I wish to know whether my Chief Secretary is expected to make any opposition to the motion which will be made by $\mathrm{Mr}$. Grattan declaratory of the independence of the Irish

* IacNerin's Volunteers, p. I66. †Lecky, IV., pp. 535-536. 
Parliament. I have in former letters observed to your Lordship (Lord Hillsborough) that my Government on every other point has the support of a most respectable and very large majority, and even resisted this particular question in several shapes in the course of the present session, but that under the universal eagerness throughout the kingdom to have this claim decided I cannot expect the friends of the Administration to sacrifice for ever their weight among their countrymen by a resistance which would probably lead to serious consequences. . . . The friends of the Government who might be supposed to support tenets contrary to the principle of independent legislation would lose their weight in this country if that point should remain long undecided. The Volunteer Associations (already in some places made use of in electioneering purposes) have set the example in the County Galway by withdrawing themselves from the command of Mr. Daly and of other gentlemen who have shown themselves well-wishers of administration. . . . It is my serious opinion that if the first day of the next meeting of Parliament does not quiet the minds of the people on that point, hardly a friend of the Government will have any prospect of holding his seat for a County or popular Corporation, and, what is more immediately interesting, they will also lose their present subsisting influence over armed associations.* 
XV .

\section{THE CONSTITU'IION OF 1782 .}

The representations of Lord Carlisle in reference to the state of the country, and, in vicw of the popular feeling, the absolute impossibility of maintaining with effect the power assumed by the British Parliament of legislating for Ireland, were rendered futile by the resignation of Lord North's Government on the 2oth March, 1782, just four days after Lord Carlisle had written a letter reviewing very fully the position of the Irish Administration and the principal incidents in his term of office, and strongly suggesting reforms in accordance with the trend of Irish public opinion. The Government of the Marquis of Rockingham, whose head and members, notably Mr. Fox, had been favourable to Irish claims, had not entered into office before, as we have seen, the Habeas Corpus Act had become law in Ireland, and the heads of a Bill, giving to the Judiges the security of tenure guaranteed to Judges in England under the provisions of the Act of Settlement, had been returned from England, and were rapidly passing as a Bill through the Irish Parliament. Mr. Eden, Lord Carlisle's Chief Secretary, had gone over to England with Lord Carlisle's resignation, but, on hearing that Lord Carlisie had been removed from the Government of Ireland under circumstances which he conceived to amount to personal discourtesy, took advantage of his position as a Member of the British Parliament to move for the repeal of the principal pro- 
visions of the Act of George I., asserting the power of the British Parliament to make laws binding on Ireland.* This proceeding was deeply resented as an effort to bring the Ministry into a declaration of their Irish policy by a gentleman who, when in office, had carried out the Irish policy of the Government of which he was a member in resisting, as far as he could do with prudence, Irish popular demands. It, however, produced the desired effect, since, on the very next day (April gth, 1782) a Royal message was sent to both Houses of the British Parliament deploring the discontent in Ireland, calling on Parliament to take it into consideration " in order to effect such a final adjusiment as may give mutual satisfaction to both Kingdoms." The Irish Parliament was to meet after its adjournment on April r6th, the day for which Grattan had given notice of moving the Declaration of Irish Independence. The Duke of Portland, who had been appointed to the Lord Lieutenancy, and Mr. Fitzpatrick, his Chief Secretary, an Irish gentleman, arrived in Dublin on April I4th. Great pressure was brought on Mr. Grattan and on Lord Charlemont to secure the postponement of Grattan's motion in order to enable the new Government to become familiar with the situation. They were both firm. in resisting that proposal, and they both refused to accept office which was pressed upon them.t Accordingly, on the meeting of Parliament, Portland, while refusing to adopt the Declaration of Independence, sent a message to the effect that " His Majesty, being concerned to find that discontents and jealousies were prevailing among his loyal subjects in Ireland upon matters of great weight and importance, recommended the House to take these

*Leckv, IV., p. 544. Froude, II., pp. 348-349.

† Lecky, IV., pp. 544-545. 
matters into their most serious consideration, in order to effect such a final adjustment as might give mutual satisfaction to his Kingdoms of Great Britain and Ireland." George Ponsonby moved a formal reply, and then Grattan rose to move as an amendment a ceclaration of rights and grievances. In a speech of unrivalled eloquence and high-wrought enthusiasm he moved the amendment, asserting that, while the Crown of Ireland was inseparably united to that of England, Ireland was by right a distinct Kingdom ; that the King, Lords and Commons, and these alone, had a right to bind her, and that the discontents and jealousies of the nation were chiefly due to three great infringements of her freedom: (I) the clains advanced by the British Parliament in the Act of George I. to legislate for Ireland and exercise a right of final judicature ; (2) the power exercised under Poynings' Law by the Privy Council to suppress or alter Irish Bills, and (3) the Perpetual Mutiny Act, which placed the Irish Army beyond the control of the Irish Parliament. * This address passed unanimously. An address of congratulation to the new Lord Lieutenant was passed likewise unanimously, and a resolution of thanks to Lord Carlisle, the late Lord Lieutenant, was carried " without a division, there being about five noes." Portland was surprised to observe that the Irish Parliament attributed little if any importance to the change of Government, and were of opinion that he and Fitzpatrick " were only carrying out the plan which they had forced their preceding Governor to adopt." He told the British Cabinet in the plainest terms that the demands embodied in the Addresses of both Houses. were irresistible, and that every point must be conceded. "It is," he wrote, " no longer the Parliament of Ireland

*Lecky, IV., pp. 545-548. 
that is to be managed or attended to. It is the whole of this country. It is the Church, the Law, the Army (I fear when I consider how it is composed), the merchant, the tradesman, the manufacturer, the farmer, the labourer, the Catholic, the Dissenter, the Protestant, all sects, all sorts and descriptions of men, who, I think mistakenly on some points, but still unanimously and most audibly (the Volunteers were sending up declarations thanking Grattan and the Parliament, and the Grand Juries were adopting a similar course), call upon Great Britain for a full and unequivocal satisfaction."* The Irish Parliament adjourned a few days after the carrying of the Declaration of Rights on April 27th tiil May 4th, and from May 4th till May 27th, when the King's reply to the Addresses was awaited.

In the meanwhile the opinions of the Lord Lieutenant had prevailed with the British Cabinet, and on May r 7 th resolutions were brought forward in both Houses of the British Parliament-in the House of Lords by Lord Shelburne, and in the House of Commons by Mr. Fox -in concession of the Irish demands. The decision of the Government was announced to repeal the Declaratory Act of George I.; to abandon the appellate jurisdiction of the English House of Lords; to consent to such a modification of Poynings' Law as would annihilate the exceptional powers of the two Privy Councils, and to limit the Mutiny Act.* The resolutions passed unanimously through the House of Commons and, with one dissentient roice-that of Lord Loughborough-through the House of Lords. A Bill repealing the Act of George I. was immediately introduced and quickly placed on the English Statute Book, and when the Irish Parliament

- Lecky, IV., pp. 548-550. Froude, II., pp. 359-360. 
met on the 27th May, the Duke of Portland announced that the King was prepared to give his assent to Acts to prevent the suppression of Bills in the Privy Council of this Kingdom, and the alteration of them anywhere, and to limit the duration of the Mutiny Act to two years. The idea of Fox was indeed realised, " to meet Ireland on her own terms and give her everything she wanted in the way in which she seemed to wish for it." Ireland was not slow in showing her gratitude. A sum of $f_{100,000}$ was voted on the motion of Grattan himself towards furnishing 20,000 additional troops to the British Navy. The Irish Parliament, notwithstanding the pledge given by Lord Townshend, that 12,000 of the troops in the Irish Establishment should always be kept in Ireland for its defence, except in the case of actual invasion or rebellion in England, authorised the King to withdraw from Ireland at any time before December 25th, 1783, an additional force of 5,000 men. This proceeding was by no means pleasing to Portland, who was afraid of the Volunteers, although ostensibly a protagonist of the popular movement, but ultimately 3,245 troops out of the 5,000 were sent over to England.*

It has often been noticed that the Irish Parliament became the exponent of toleration in proportion to its increasing freedom. The Constitution of 1782 had only just been established when Bills, introduced by Colonel Gardiner, the author of the Catholic Relief Act of 1778 , eventually became law-one enabling Catholics who had taken the oath of allegiance and declaration enacted under Lord Harcourt's administration to purchase and bequeath land like Protestants, provided it was not in a Parliamentary borough, and abolishing obsolete provisions of the

*Lecky, IV., pp. 552-555. Froude, II., pp. 369-371. 
Penal Code; another allowing Catholics to become schoolmasters, teachers, and private tutors, provided they took the oath of allegiance and subscribed the declaration and took no Protestant pupils. In the same Session an Act was passed to give retroactive legal validity to marriages of Protestant dissenters celebrated by their Ministers in their meeting-houses, and to give dissenting Ministers, so far as their co-religionists were concerned, the same rights of celebrating valid marriages as Anglican Churchmen. Acts, moreover, were passed modifying Poynings' Law in such a manner as to render the legislative independence of the Irish Parliament subject to the veto of the Crown absolute, confirming a large number of British Statutes relating to Ireiand, for the most part dealing with title to land and religious questions, limiting her Mutiny Acts, and establishing the rights of final judicature and the independence of the Irish Judges. A grant was made to Grattan of $£ 50,000$. The House of Commons wished him to be the recipient of $f_{100,000-a}$ proposal he positively refused to entertain. The $£ 50,000$, with a residence, he accepted, at the same time pledging himself to devote his life and energies exclusively to public affairs and not to resume the practice of his profession at the Bar. This promise he kept to the letter.*

The business of the Irish Parliamentary Session was wound up by an Address to the Duke of Portland, which was written by Grattan himself, thus describing the merits of the newly-established Irish Constitution :

"We have seen the Judges rendered independent of the Crown, the Mutiny Law abridged in duration, the jurisdiction of the hereditary Judges of the land restored, the vicious mode of passing laws in this land reformed,

$$
\text { * Lecky, IV., pp. 556-558. }
$$


the sole and exclusive right of legislation, external as well as internal, in the Irish Parliament firmly asserted on the part of Ireland and unequivocally acknowledged on the part of Great Britain. We have seen this great national arrangement established on a basis which secures the tranquillity of Ireland and unites the affections as well as the interests of both Kingdoms."*

The Constitution of 1782 , notwithstanding this glowing description, was as yet without its coping-stone, to use Mr. Lecky's term†-the Renunciation Act of 1783 . For the purpose of a more succinct narration, the circumstances of the enactment of this measure may here be given by way of anticipation. The English Act of 6th George I., which was a complete assertion of authority over the legislature and Kingdom of Ireland, and a practical denial of its Parliamentary independence, was, as we have seen, repealed in 1782 by the British Parliament. The mere repeal of this Statute did not satisfy Mr. Flood, who contended, with the support of some eminent lawyers in the House of Commons and with the cordial approbation of the Volunteers, that there should be a complete and absolute renunciation by the English Parliament of all claims to legislate for Ireland. " It is," he said, " an undeniable principle of law that the mere repeal of a declaratory Act does not renounce the principle of it, and it is clear to common sense that nothing but a final renouncing of the principle of this law is adequate to our security. With regard to this law of George I., the maxim I have mentioned obtains with peculiar force. What is the title of the law ? It is an Act for the better securing of the dependency of Ireland. On the face of it, therefore, it imports expressly

$$
\text { * Froude, II., p. } 380 . \quad \text { †Lecky, VI., p. } 313 .
$$


that dependency did before exist, and that, by consequence, it must continue till expressly renounced. It had, indeed, too strong an antecedent existence to be destroyed by any weak implications. The first authority known to the English law is that of the great Lord Coke. His authority is expressly against us and in favour of the English Parliament. Will any lawyer say that the clear and decided opinion of Lord Coke in a matter of law is to be contemned? Add to this a number of Statutes made by the English Parliament and acquiesced in by the Irish Nation antecedent to the declaratory law of George I., and will any man be so rash, so foolish, or so corrupt as to say that such pretension is to be overlooked ? or that it can be rationally stated to be so void of principle and colour as that a bare repeal of a subsequent and declaratory Act can annihilate it ?"* Grattan, on the other hand, contended that the simple repeal of the Statute was abundantly sufficient to secure the complete legislative independence of Ireland, and the Irish Parliament inclined to this view, although the public opinion of the country at large was averse thereto. Lord Mansfield, the Lord Chief Justice of England, in Michae!mas, 1782 , and after this question of renunciation as distinguished from simple repeal had been raised, pronounced judgment in an Irish appeal. The case, however, had been carried to England long before the repeal of the Act of George I. Complaints were made of Lord Mansfield's decision in the British House of Commons. On the 22nd January, 1783 , Mr. Secretary Townshend introduced a Bill in the British House of Commons, which William Grenville, the Secretary to Lord Temple, who was then Lord Lieutenant, came over

$$
\text { * Irish Debates, I., pp. 417-418. }
$$


to explain and support in that assembly, for removing and preventing all doubts which may have arisen or may arise concerning the exclusive rights of the Parliament and Courts of Ireland in matters of -legislation and judicature, which was carried without difficulty (23 George III., c. 8). In a remarkable letter to the British Cabinet urgin; the immediate necessity of this legislation, the Lord Lieutenant writes: "Two Irish causes are now before the English House of Lords. If it should decide them I will not answer for the effect of such a judgment twenty-four hours after it is known."*

The death of the Marquis of Rockingham, the British Prime Minister, in July, 1782, brought to a close the Viceroyalty of the Duke of Portland, who, with his Chief Secretary, Colonel Fitzpatrick, left Ireland-Earl Temple succeeding the Duke in the Lord Lieutenancy. The Portland Administration must always be had in remembrance for the establishment of the Irish Constitution of 1782 , of which the British Act of Renunciation in 1783 was the completion. The arrangement of 1782 , to which the British Cabinet, of which Mr. Pitt, the author of the Union, was a prominent supporter, was no provisional plan, but a final and determinate settlement between the legislatures of the two countries. Speaking in the English House of Commons on Iith February, I799, against Mr. Pitt's Union proposals, General Fitzpatrick made this memorable statement: " $\mathrm{He}$ was in Ireland, and had a seat in the House of Commons there, when the resolutions (in relation to Irish Parliamentary independence) passed in 1782 . He held at that time an official situation. The whole of that assembly almost was well disposed to these resolutions, but there was one member of that House, 
who was afterwards a member of this, who was not very well disposed to them-he meant Mr. Flood. He called upon him as an official person in that House to say whether there was any other measure to be grounded on that resolution, to which he answered and assured that gentleman, from the authority of those with whom he acted, there was no constitutional measure to be brought forward. There were some measures to be brought forward on commerce and he knew not what, but, strictly speaking, there was nothing remaining of a constitutional point to be settled. Surely the Union was a constitutional point, and therefore was so far inconsistent with the settlement of 1782 , which he assured Mr. Flood was not to be followed by any measure whatever. This he assured that gentleman. He would venture to say that, for the fifteen years following this resolution, there had been no doubt entertained upon the independence of the Irish Legislature in a constitutional point of view. He confessed, therefore, he was surprised to hear the right honourable gentleman (Mr. Pitt) say anything of a slighting nature against the settlement of 1782. He must consider him as a party to that settlement. He was a strenuous supporter of the Rockingham Administration. He was a very active Member of Parliament ever since he came into that House. He would go further and say it was a settlement which not only had the approbation of the right hon. gentleman, but was a measure that was universally approved of. It had the approbation of many of those who were now the friends and adherents of the right hon. gentleman, some who had been called into another place for changing their political sentiments, while he remained where he was, because he had not changed them." General 
Fitzpatrick himself had in June, 1782 , as Irish Secretary in the Irish House of Commons, stated that he had been authorised publicly to disavow any intention of bringing forward further measures in reference to the settlement of the constitutional relations between Great Britain and Ireland, which were final.* Stung by General Fitzpatrick's speech, Mr. Pitt stated that the arrangement of 1782 was not final and not considered to be final by the Duke of Portland, and that he could, by documentary evidence, convince him of his error. Mr. Pitt consented, in the event of General Fitzpatrick adhering to his view, to produce this evidence to the British House of Commons. The documents-seven letters, the first dated 6th May, 1782 , and the last 22nd June, 1782 -were produced, from which it appeared that the Duke of Portland, who, eighteen years afterwards, was one of the principal machinators by corrupt methods of the Union, when Lord Lieutenant of Ireland in 1782 , without the knowledge of the Chief Secretary, had been attempting to regain a large part of the legislative supremacy which England had surrendered in $\mathbf{1 7 8 2}$ under the arrangement of which the Duke was the avowed supporter as the Lord Lieutenant in a Government by which that arrangement had been effected. $\dagger$

* Parliamentary Register, VIII., pp. I I-I 5.

+ Parliamentary Register, VIII., pp. 535-54I. 


\section{XVI.}

\section{THE IRISH PARLIAMENT AND THE}

\section{VOLUNTEER CONVENTION.}

The Constitution of 1782 was, as I have endeavoured to explain, subject to defects which were fatal to its efficiency as a legislature and as a control of the Executive. The House of Commons was, in the first instance, essentially unrepresentative, only 128 of its three hundred members being returned by a semblance of popular choice. In an overwhelmingly Catholic country no Catholic was competent to be elected or even till 1793 to vote for a Parliamentary candidate. In Ireland there never was an Executive responsible to the Parliament or through that Parliament to the people. The Irish Government, the Lord Lieutenant and his Chief Secretary, owed their position to the British Government, and on a change of that Government vacated their offices, whether they possessed the confidence of the Irish House of Commons or otherwise. There was no serious conflict between the Irish House of Lords and the Irish House of Commons, because in truth the Lower House was to a great extent the creation of the Upper one. It was computed in $I 783$, as I have previously stated, that 124 Members of the House of Commons were absolutely nominated by 53 Peers, while 91 others were chosen by 52 Commoners. The Irish Parliament, we have seen, did not refiect the views even of the Irish Protestant population on the questions involved in the War of the American 
Independence. Grattan's Constitution, as it has been termed, was achieved not by the Irish Parliament proprio motu as the exponent of the views of the people, but by pressure from without by the Volunteer Movement, which was the outcome of public opinion, bringing irresistible influence to bear on the Irish Parliament. The confidential correspondence of the Lords Lieutenant to the English Cabinet, in which the loyalty and devotion of the friends of Administration are admitted and praised, and the fact of their impotence to resist the clearly expressed will of the nation is admitted and deplored, are conclusive proof that the Constitution of 1 782 was not the independent work of the Irish Parliament, but the product of pressure from without which that Parliament could neither resist nor control. The Duke of Portland, whose short Viceroyalty was terminated by the death of Lord Rockingham in July, 1782 , brought in June, 1782 , to the notice of the Cabinet the fact that Parliamentary reform had become the subject of serious discussion.* Earl Temple, afterwards Marquis of Buckingham, the Duke of Portland's successor, in his first Viceroyalty, which lasted from September, 1782, till the following March, and corresponded with the Shelburne Ministry in England, was quick in perceiving the signs of the times. A few days after his landing in Ireland he writes to the British Cabinet- " No Government exists. Those to whom the people look up with confidence are not the Parliament, but a body of armed men, composed chiefly of the middling and lower orders, influenced by no one, but leading those who affect to guide them." $\dagger$ He strenuously supported the policy of the Renunciation Act of 1783 , with a desire of strengthen-

$$
\text { * Lecky, YI., p. 323. † teckl, VI., py. 309-310. }
$$


ing the sham Irish Parliament in a contest with the people. He instituted the Order of the Knights of St. Patrick, the first Knighthoods being in many cases purchased, the proceeds forming a fund for the bribing of Members of the House of Commons. In his secret correspondence he avows his desire "to foment that spirit of disunion among the Volunteers, on which alone I found my hopes of forming a Government." Again" Nothing but a Parliament can recover the Government and be opposed to the Volunteers."* Although Lord Temple resigned the Viceroyalty in March, 1783 , on the fall of Shelburne and the formation of the Coalition of Fox and North, he was not permitted to leave Ireland till June, when Lord Northington, who had been appointed his successor, came into residence. The circumstances connected with the passing of the Renunciation Act, a measure which was at first regarded as unnecessary and invidious by the Irish Parliament, gave a powerful stimulus to the agitation for Parliamentary reform. A dissolution for which Temple had been preparing took place immediately after the arrival of Lord Northington, and it seemed clear that the life of the new Parliament would be signalised by the struggle for Parliamentary reform which sooner or later was recognised as inevitable. The Viceroyalty of Lord Northington, which commenced on June 3 rd, 1783 , and terminated in February, 1784, forms a most important epoch in the constitutional history of Ireland. Shortly after his arrival the Parliament of 1776 , in whose existence Grattan's Constitution was established, was dissolved, and followed by a general election, the new Parliament meeting in October, 1783. Among the measures which

$$
\text { * Lecky, VI., p. } 3 \text { Iо. }
$$


were announced in the speech from the Throne were the establishment of a separate Post Office and Court of Admiralty in Ireland, and at this time the system of annua! sessions was substituted for the system of biennia! sessions, and, as a corollary of the change, the Mutiny Ac: was passed for one year instead of for two years. An annual session of Parliament was strongly urged as a constitutional antidote to the effect of Conventions, and likewise as a means of expediting the decisions of Appeals by the Irish House of Lords, which had now become the final tribunal.* But the great issue was the question of reform, or, in other words, the contest between the Volunteers, on one hand, who were pressing for the comprehensive reform of the Irish Parliament, by making that body the exponent of the wants and wishes of the people, and the effective means of carrying out those wants and wishes, and the Parliament itself, on the other hand, two-thirds of the Members of whose House of Commons were the nominees of influential individuals. On March Ist, 1783 , a provincial meeting of Volunteers at Cork passed resolutions in favour of Parliamentary reform, and on July Ist, I783, delegates of fortyfive companies of Ulster Volunteers assembled at Lisburn, who met at Belfast on July 19th, resolved to convoke for the ensuing September a great meeting of Volunteers at Dungannon to consider the best way of obtaining a comprehensive measure of Parliamentary reform. The general meeting of the delegates of the whole Province of Ulster, which was held in Dunga nnon on September 8 th, 1783 , passed resolutions declaring that inasmuch as a majority of the House of

* I.ccky, VI., p. 327.

* Hardy's Life of Lord Charlemoint, II., p. 94. 
Commons were elected by the mandates of a few Peers and Commoners, that House was in no sense a representation of the people; that the franchise ought of right to extend to all those and those only who are likely to exercise it for the public good, and that the present imperfect representation and long duration of Parliament were intolerable grievances. They at the same time called on the few representatives of free constituencies to refuse to vote any but short Bills of Supply till their grievances were redressed; expressed the warmest sympathy with the English and Scotch reformers, and summoned the Volunteers of all four provinces to meet together to elect a Convention of delegates chosen by ballot from each county in Ireland. This Convention was to meet in Dublin on November roth, shortly after Parliament had assembled and while it was still sitting, to frame a plan of reform and to demand those rights without which " the forms of a free nation would be a curse" (Lecky's History of England in the Eighteenth Century, VI., p. 336). The Lord Lieutenant was under no delusion as to the result of a contest between the Volunteer Convention and the Irish Parliament on the subject of Parliamentary reform. A few days after the

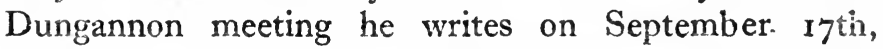
I783, to Lord North-"A Parliamentary reform is the grand subject intended to be proposed by the delegation of the Volunteer Corps. There can be no room for apprehension with regard to the fate of this question when the present constitution of the House of Commons in this country is referred to."* On November roth, 1783 , the opening meeting of the Volunteer Convention was held in Dublin. The delegates being very numerous

* Fronic, Ii., p. 404. 
the place of meeting was altered from the Royal Exchange, the rooms of which were too small, to the Rotunda. Lord Charlemont, in response to a Committee appointed for the purpose of arranging the meeting at Dungannon, which he did not attend, who requested him to indicate such specific method of reform as appeared most suitable to the condition of Ireland, strongly urged the policy of pressing for a measure of reform exclusively, and advocating the adoption of the principle of Parliamentary Reform, leaving the details of the measure to the discretion and deliberation of Parliament.* Lord Charlemont had considerable doubts as to whether he should ofier himself for election as a delegate to the Convention, and at last came to the conclusion that it was better that he should be a member of the Convention of which he disapproved, in the hope that his presence might have a moderating influence on the proceedings and serve as a check on the policy of the Earl of Bristol, who was Bishop of Derry, and had openly proclaimed his desire for the admission of Roman Catholics to the Parliamentary franchise and to seats in Parliament. Many friends and supporters of Lord Charlemont became delegates with a similar object. Lord Charlemont was unanimously chosen President of the Convention. "The same reason," he writes, "which induced me to accept the nomination from Armagh and to persuade many mocierate friends of mine much against their wishes to be delegated, namely, that there should be in the assembly a strength of prudent men suficient by withstanding and preventing violence to create moderate measures, induced me now to accept the troublesome and dangerous office of President, which was unanimously roted to me.

* Hardy's Life of Lord Charlemont, II., pp. 96-98. 
Further reasons also concurred to prevent my refusal. The Bishop of Derry had, I know, done all in his power to be elected to that office, and I found that, if I should refuse, the choice might fall on him, which would, indeed, have been fatal to the public repose."* The Convention adopted, so far as it was practicable to do so, the rules, orders, and customs of Parliament. Having passed resolutions declaring that the Protestant inhabitants of this country are required by statute law to carry arms or have the use of them, and are not by their compliance with the law excluded from their civil rights, and asserting their attachment to the Sovereign and the Constitution, they resolved themselves into a committee of which Mr. Brownlow was appointed Chairman, and then a Sub-Committee, consisting of one member from each county, was appointed to frame a plan of reform for the approbation of the Convention.t The Committee was embarrassed by a multiplicity of plans of reform, in many instances introduced by the friends of the Government, in the words of Lord Northington, " to perplex its proceedings and to create confusion," and above all to kindle dissension in reference to the Catholic question, which was at last settled by the exclusion of Catholics from the proposed scheme of reform, owing to a statement made by Sir Boyle Roche, for which there was no foundation, that he had been commissioned to say that the Catholics did not wish to press their claims to the franchise and disavowed a desire for an immediate alteration in their position.f Little progress was made under such conditions till Flood, who was not on the Committee, was, on the motion of the Bishop of Derry,

* Hardy's Life of Lord Charlemont, II., p. 105.

† Hardy's Life of Charlemont, II., p. Io7. Lecky, VI., pp. 342-343.

+Lecky, VI., pp.367-368. Froude, II., pp. 4I8-4I9. Hardy's Life of Lord Charlemont, II., pp. IO7-I II. 
nominated as an assessor. He soon obtained a complete ascendancy in the proceedings. The Bishop more than once endeavoured to bring forward the question of the Catholic franchise, but was defeated by the opposition of Flood and Charlemont. So rapid and decisive was the superiority which Flood obtained that without his concurrence nothing was approved of. At last Mr. Flood produced his own plan for new-modelling the House of Commons. It was adopted by the SubCommittee, and was then submitted to the Grand Committee, as it was called. Having passed the ordeal of the two Committees, it was finally reported to the Convention, when the proposal of the Bishop of Derry in support of Catholic claims was once more defeated. Mr. Flood's Reform Bill proposed to restrict the right of voting, except in the case of electors who possessed freehold or leasehold property of $£_{20}$ a year ; to men who had actually resided in the constituency six months out of the preceding twelve; to throw open the decayed boroughs by extending their franchise to the neighbouring district; to annul by Act of Parliament the bye-laws by which any Corporation had contracted the right of franchise ; to give votes to all Protestants resident in any city or borough who possessed freeholds or leaseholds of a specified value and duration; to incapacitate all who held pensions during pleasure from sitting in Parliament ; to compel every Member of Parliament accepting a pension for life or any place under the Crown to vacate his seat and submit to a new election; to oblige all Members to swear that they had not given money for their seats, and, finally, to limit the duration of Parliament to three years.* A proposition to recommend vote $b y$

$$
\text { *Lecky", VI., pp. 343-344. }
$$


ballot was rejected, and Flood's pian of reform was agreed upon. Charlemont and five other borough proprietors who sat in the Convention deciared their readiness to surrender their patronage. Flood rose in the Convention about 4 o'clock in the afternoon of Saturday, November 2gth, and proposed that he, accompanied with such Members of Parliament as were then present, should immediately go down to the House of Commons and move for leave to bring in a Bill exactiy correspondent in every respect to the plan of reform which he had submitted to and was approved by the Convention. To this proposition he added another: "That the Convention should not adjourn till the fate of his motion was ascertained." Both motions were carried. "A more complete designation and avowal," writes Hardy, " of a deliberative assembly, co-existing with Lords and Commons and apparently of co-extensive authority, could scarcely be made. It was in truth like bringing up a Bill from the Bar of one House of Parliament to that of another." (Life of Charlemont, II., p. I33.) Mr. Lecky is of a similar opinion. "It would be impossible," he writes, "to assert more strongly the position of the Convention as a kind of rival Legislature, and to bring it more directly into conflict with Parliament" (Lecky's History of Englant in the Eighteenth Century, VI., p. 343). It should not, however, be forgotten that the Convention was more truly representative of the people of Ireland than the corrupt rotten borough Parliament. "If," wrote a member of the Sub-Committee, "property and fortune are the criteria of consequence, the members of the Convention were of equal importance and possessed an equal interest in the public welfare as the Members of the House of 
Commons.... There cannot be a more irrefragable argument in favour of a reform of Parliament than, originating with the people, that it should be embraced by almost every man of rank and fortune in the kingdom except the individuals whose respective interests and occupations were supposeci to be affected by a more equal representation" (History of the Last Session of Parliament, by a Member of the Sub-Committec of the Convention, pp. 9-IC). A record of the reception in the House of Commons of Mr. Flood's motion for leave to introduce the Reform Bill has been given by a Member of that Assembly who was an eye-witness and participator in the proceedings, Mr. Hardy, the biographer of Lord Charlemont, who was then in the first year of his highly honourable Parliamentary career. "Whoever was present," he writes, " in the House of Commons on the night of the 29th November, 1783 , cannot forget what passed there. I do not use very disproportionate language when I say that the scene was almost terrific. Several of the minority and all the delegates who had come from the Convention were in (Volunteer) uniform, and bore the aspect of stern hostility. On the other hand, Administration, being supported on this occasion by many independent gentlemen, and having at their head very able men such as Mr. Yelverton (the famous framer of the Yelverton Act, afterwards Viscount Avonmore and Lord Chief Baron of the Exchequer), and Mr. Daly (an eminent Parliamentary orator who died in early life), presented a body of strength not always seen in the ministerial ranks, looked defiance to their opponents, and indeed seemed almost unassailable. They stood on most advantageous ground, and that ground was given to them by their adversaries. Mr. Flood, flushed 
with his recent triumph in another place, and enjoying the lofty situation which his abilities always placed him in, fearlessly led on the attack. Mr. Yelverton answered him with great animation, great strength of argument, and concluded with a generous, dignified appeal to the Volunteers, whom he applauded for every part of their conduct, the present alone excepted. Some speeches followed in a similar tone, but the minds of men became too heated to furnish any regular debate whatever. It was uproar, it was clamour, violent menace and furious recrimination. If ever a popular assembly wore the appearance of a wild and tumultuous ocean it was on this occasion; at certain and then very short intervals there was something like a calm, when the dignity of Parliament, the necessity of supporting the Constitution, and the danger of any military assembly were feelingly and justly expatiated on. The sad state of the representation was with equal truth depicted on the other side. A denial of Volunteer interference and the necessity of amending the representation, whether Volunteers existed or not, was in the first instance made with very imperfect sincerity, and in the latter with genuine candour. To this again succeeded tumult and confusion, mingled with sad and angry voices of many who, allied to boroughs, railed at the Volunteers like slaves, not gentlemen, and pretended to uphold the Constitution, whilst they were in truth appalled at the light that now began, as their terror suggested, to pervade their ancient and ambiguous property. But the imprudence of the Volunteers was of more service to such men than all their array of servile hostility. On that night, at least, it proved their best safeguard, and placed them not within the shadowy uncertain confines of a depopulated borough, 
where they could find no safety, but under the walls of the Constitution itself. The teripest (for towards morning debate there was none) at last ceased; the question was put and carried, of course, in favour of the Government; their number 159, those of the Opposition 7\%. This was followed, and wisely, too, by a resolution 'declaratory of the fixed determination of the House to maintain its privileges and just rights against any encroachments whatever,' and that it was then indispensably necessary to make such a declaration. An address to be carried to the Throne as the joint Address of Lords and Commons was then moved for, in which, after expressing their perfect satisfaction in His Majesty's Government, they declared their determined resolution to support that Government with their lives and fortunes. This Address was carried to the Lords, and immediately agreed to " (Hardy's Life of Charlemont, II., pp. $135^{-138)}$. Grattan, who absolutely disapproved of the Convention and of its proceedings, supported the proposition to consider the Bill on its merits, but he voted silently for the resolution declaring the determination of the House to maintain its rights and privileges against all encroachments. The Convention had remained in Session till long after midnight, awaiting the result of the division in the House of Commons on Flood's motion in accordance with their resolution, when Charlemont with some difficulty induced them to adjourn till the Monday following. On Sunday he held a meeting of his own friends in Charlemont House, and they agreed together that the Convention should be dissolved. On Monday, December Ist, the Convention again met. The moment Lord Charlemont took the chair, Captain Moore began to speak in denun- 
ciation of the House of Commons for the treatment accorded to Mr. Flood's motion and for disparaging remarks in debate with reference to the Convention. Lord Charlemont promptly called him to order, and said " that one of the wisest things in Pariiament was never to take notice in one House of what was said in another." The observation of such a rule he then begged particularly to recommend to the Convention. A resolution was passed asserting anew the manifest necessity of a Parliamentary reform. The delegates agreed to forward the plan of reform to their several districts and to endeavour, by public meetings, petitions, instructions to members and the publication of abuses, to obtain for it a great weight of civil support. At the request of the Bishop of Derry, Mr. Flood, while earnestly deprecating violence, proposed that there should be an Address from the Irish Nation to the King, which he composed and moved himself, embodying a protestation of loyalty to the Sovereign, a recital of the services to the Realm of the Volunteers, and concluding with these wrods: "And to implore your Majesty that our humble wish to have certain manifest perversions of the Parliamentary Representation of this Kingdom remedied by the Legislature in some reasonable degree may not be imputed to any spirit of innovation in us, but to a sober and laudable desire to uphold the Constitution, to confirm the satisfaction of our fellow-subjects, and to perpetuate the cordial union of both Kingdoms."*

The Convention was then peacefully dissolved. Its failure to secure a measure of Parliamentary Reform may be regarded as the death-warrant of the Irish Parlia-

* Lecky, VI, pp. 345-346. Froude, II., 406. Hardy's Life of Lord Charlemont, Il., pp. I 38-142. 
ment, which was put into execution seventeen years later. No fewer than 138 of the majority of the Irish House of Commons who refused to give leave for the introduction of Mr. Flood's Reform were placemen, or the very persons on whom the reform was intended to operate. The House of Commons was not afraid to flout the Convention because they knew that many of its Members sought and secured election not to promote its aims, but with the view, in the words of Lord Charlemont in respect to his own attitude, of being useful towards guiding and moderating those efforts which they could not with efficiency oppose. The Reform Bill was essentially a half measure, the proposal of one million of divided Protestants in their own interests, as they conceived, to the exclusion of three millions of united Catholics. If Flood's measure of reform had extended to the enfranchisement of Protestants and Catholics alike, if it had been proposed in the name and with the support of a United Nation, the demand would have been irresistible, the rotten boroughs would have been swept away in a storm of contempt and indignation, and, in the words of an address to the Bishop of Derry, who was the exponent of this policy, "the Augean stable-the noisome stalls of venality and corruption-would have been cleansed," and the Union would never have been carried. The historian of the Volunteer Movement thus sadly sums up the effect of the Convention which sealed the fate of the old Volunteers, as Grattan used to call them: "The Dublin Convention was an error. It was a rival Parliament, and as such it violated the spirit of the Constitution. It was the Parliament of a minority, for it excluded Catholics from the benefits it proposed to confer. The nation was indifferent to the 
contests of two rival assemblies, one the organ of a Government, the other the organ of a faction. As a great measure of revolution the Convention would have been all-powerful if the Volunteers were ready to back its mandates with their arms and the people with their sympathies. But the Volunteers were irresolute-the people were apathetic. It was a madness to suppose that a mere oligarchy could contend with the forces of England. . . . That fatal disunion-that mixed feeling of religious hatred, personal suspicion and contempt with which the Catholics of Ireland were regarded by the Protestant people-gave way for a while to the enthusiasm of volunteering, and seemed to be exorcised by the Convention of Dungannon. But it revived after the concessions of Parliamentary independence. The aristocratic party, the nobility of the Parliament, were contented with their own triumph and jealous of all participation in their glory. They churlishly refused to the Catholics their political rights. It became an easy task for the dark and evil genius of the greatest of English Ministers (Mr. Pitt) to ripen the seeds of division. The Catholics were disgusted and the Protestants deceived. If Grattan had gone on with the movement, his tolerant genius would possibly have influenced the timid spirit of Charlemont and rendered his bigotry as harmless as it was contemptible. The Volunteers would have become a national body, not an aristocratic institution, and the Constitution of I782 would have withstood every effort of England to destroy that 'final adjustment" (MacNevin's History of the Volunteers, pp. 217-218). The Volunteers practically expired with the Convention. They held annual reviews, they passed addresses and resolutions, but 
henceforward their proceedings were without effect. When at length they came into direct collision with the military, they wisely declined the contest. A few country corps had fixed upon holding a review at Duah, in the County of Antrim. The military marched to the spot to disperse them, but the Volunteers avoided assembling, and when the Government issued its mandate that every assemblage of the body should be dispersed by force, "the phantom of the Army of Ireland had passed from the scene for ever." (MacNevin's History of the Volunteers, p. 215; MacNevin's Pieces of Irish History, p. 58.) 
XVII.

\section{THE IRISH PARLIAMENT AND “ORDE' COMMERCIAL PROPOSITIONS."}

The successful resistance of the Irish Parliament to the demand for its reform advanced by the Volunteer Convention of 1783 was, in reality, equivalent, as I have said, to the signing of the death-warrant of that assembly. In the very session which witnessed the discomfiture and dissolution of the Volunteer Convention, a signal proof of the reactionary spirit which a successful resistance to popular demands inevitably generates was afforded by the rejection of the Bill imposing a tax of four shillings in the pound on all rents remitted out of the Kingdom to non-resident landowners. In the time of the Harcourt Administration in $\mathbf{1 7 7 4}$, this very measure had been all but carried. It was then rejected by the narrow majority of 14 , whereas the minority became in 1783 a minority of 162, the Absentee Tax Bill being rejected by 184 to 22 .* The fall of the Coalition Ministry of Lord North and Mr. Fox, and the succession of Mr. Pitt to power, led to the resignation of Lord Northington and the appointment of the Duke of Rutland to the Lord Lieutenancy, with Mr. Orde, who had filled the position of Secretary to the Treasury, as Chief Secretary, and had the reputation of being the possessor of expert knowledge in matters of finance. Pitt had, at this time, two great objects in mind

\footnotetext{
* Froudc, II., pp. 429-430.
} 
in reference to Ireland-a reform of the Irish Parliament, which he knew must accompany or quickly follow a reform of the Parliament of Great Britain, on which he had set his heart, and now that the artificial restraints laid by English legislation on Irish commerce had been removed, a treaty of commerce establishing for the future a perfect free trade between Great Britain and Ireland. On the question of Irish Parliamentary Reform the Duke of Rutland, in a letter to Mr. Pitt, written from Dublin on June 16 th, 1784 , had expressed himself with great directness of language: "The question of reform, should it be carried in England, would tend greatly to increase our difficulties, and I do not see how it will be evaded. In England it is a delicate question, but in this country it is difficult and dangerous to the last degree. . . Your proposition of a certain proportionable addition of the county members would be the least exceptionable, and might not, perhaps, materially interfere with the system of Parliament in this country, which, though it must be confessed, does not bear the smallest resemblance to representation. I do not see how quiet and good government could exist under any more popular mode " (Ashbourne's Pitt, pp. 72-73).

Pitt, writing to Orde on September 19th, 1784, refers to the questions of Irish Parlaimentary Reform and of the commercial plan: "The Government can never be carried on to any good purpose by a majority in Parliament alone if that Parliament becomes generally or lastingly unpopular. We may keep the Parliament but lose the people. . . The people, by having to a certain degree a confidence in Parliament, will go to less excess than lef $t$ to the guidance of every impulse without doors. At all events, even if the Parliament of Ireland should be 
brought to invent or countenance new demands which we could not grant, a stand must be made against them. Nor do I think this country (Great Britain) would be less able to make a stand on good ground even against Parliament than with a Parliament on questionable ground against the people." With reference to the proposed commercial plan Pitt writes : "It is certainly, on general principles, desirable (though with some reservation arising from the actual circumstances) that the system of commerce should be so arranged as to extend the aggregate wealth of Great Britain and Ireland to its utmost limit without partiality or preference to one part of the Empire or the other. But for this purpose two things seem fundamentally requisite: One, that Ireland, which will thus gain upon England in relative strength and riches, should proportionately relieve her of the burden which she now sustains exclusively. The other, that this increase of strength and riches in Ireland may really prove either a positive addition to that of the Empire at large, or, at least, a transfer from one member of it to the other, and may not, in the end, be so much taken from ourselves and given to a separate country" (Ashbourne's Pitt, pp. 85-9I). With the attitude of Pitt towards Parliamentary Reform I shall subsequently deal. The commercial relations between the two countries were the subject which first engaged the more immediate attention of the Government, and, as it formed one of the two great differences between the English and the Irish Parliaments, it may be entered into somewhat fully. The Irish Government, which was, as we have seen, carried on through the instrumentality of a corrupt oligarchy, of a large compact body of members holding places and pensions at the pleasure of the Government, 
and removed by the system of rotten boroughs from all effectual popular control, had little, if any, difficulty or danger of friction in its relation with the Parliament. " On the whole, no legislative body could be found which was less troublesome to the Executive. There was one subject, and one only, on which it was recalcitrant. It was jealous in the very highest degree of its own position as an independent Legislature, and any measure which appeared even remotely to restrict its powers and to make it subordinate to the British Parliament produced a sudden and immediate revolt." (See Lecky's History of England in the Eighteenth Century, VI., pp. 442-443, and pp. 371-372.) The plan of the commercial relations between the two countries in 1785 , and the Regency questions in 1789 , fell within this category, and were the cause of explosions of passionate jealousy, resentment, and intolerance of any inferiority of the Irish Parliament in power and independence to the British Parliament. The practical boon which had been won for the Irish Nation by the Volunteers was the right of the Parliament of Ireland to control Irish harbours and to regulate Irish trade. Of course, the trade of Ireland was subject to the interference which England could exercise by her dominion over the colonies and dependencies of the Imperial Crown. A law which would have prohibited the exportation of Irish goods either to England or France or Canada would have been beyond the power of the English Parliament to pass, but it was perfectly competent to that Parliament to prohibit the importation of these goods into England or Canada, just as the French Government might have prohibited their importation into France. The English Parliament was the supreme legislature for England 
and the Colonies, and had just the same power of legislating against the importation of Irish products as they would have had against those of Holland or Russia (Butt's Irish Federalism, pp. 38-39). "The very liberal legislation of Lord North had granted to Ireland the full right of direct trade with the English plantations of Africa and America on the sole condition of establishing the same duties and regulations as those to which the English trade with the plantations was subject, and also a full participation of the English trade with the Levant, while the subsequent establishment of her legislative independence had left her absolutely free to regulate her trade by treaty with all foreign countries. The monopoly of the East India Company still excluded Ireland from the Asiatic trade. The commercial relations between England and Ireland were, of course, regulated by the Acts of their respective Parliaments. Ireland admitted all English goods either freely or at low duties; she had not imposed any prohibitory duty on them, and whenever she laid heavy duties on any article which could be produced in Great Britain, she had all but invariably excepted the British article. The British Parliament had excluded most Irish manufactures, and especially Irish manufactured wool, by duties amounting to prohibition, but in the interest of English woollen manufacturers it freely admitted Irish woollen yarn, and in the interests of Ireland it admitted linen, which was the most important article of Irish manufacture, without any duty whatever, and even encouraged it by a small bounty" (Lecky's History of England in the Eighteentin Century, VI., pp.

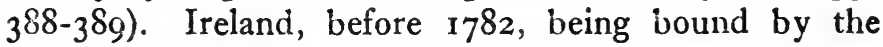
chain of Poynings' Law, was unable to protect her own industries, and it was very natural that, in the words of 
Mr. Pitt, with an independent legislature, she should now look for perfect equality. The distress which had been severe in 1783 continued in 1784 ; proposals, however, for protecting duties, for which there was much clamour outside Parliament, were rejected on the ground that measures of such a character would inevitably throw England into an attitude of hostility and produce reprisals which would probably work the ruin of the linen industry.* Pitt's proposal of a treaty establishing for the future perfect free trade between the two countries, and securing to Ireland the benefit of the colonial trade, subject to a fixed contribution by Ireland in time of peace and war for the general defence of the Empire, was presented to the Irish Parliament on February 7 th, 1785 , in the form of ten resolutions. "Their most important provisions were that all foreign and colonial goods might pass from England to Ireland and from Ireland to England without any increase of duty; that all Irish goods might be imported into England and all English goods into Ireland either freely or at duties which were the same in each country; that where the duties in the two countries were now unequal they should be equalised by reducing the higher duty to the level of the lower; that except in a few carefully specified cases there should be no new duties or bounties on exportation; that each country should give a preference in its markets to the goods of the other over the same goods imported from abroad, and that whenever the hereditary revenue exceeded a sum which was as yet not specified, the surplus should be appropriated towards the support of the naval forces of the Empire in such a manner as the Parliament of this kingdom shall direct" (Lecky's History of Englond in the Eighteenth Century, VI., Pp. 395-396).

$$
\text { * Lecky, TI., pp. 353-354. }
$$


Grattan insisted that no additional contribution should be paid to the general defence of the Empire till the Government put an end to the ruinous system of annual deficits and loans. To meet this objection a new resolution was introduced which made the contribution in time of peace contingent upon the establishment of a balance between Revenue and Expenditure. The hereditary revenue was now $£_{0} 652,000$, and was steadily rising. The new resolution provided that whatever " surplus it produced above the sum of $£_{656,000}$ in each year of peace wherein the annual revenue shall equal the annual expense, and in each year of war without regard to such equality, should be appropriated towards the support of the naval force of the Empire in such manner as the Parliament of this Kingdom shall direct." These resolutions, although they were impugned by Mr. Brownlow as " tending to make Ireland a tributary nation to Great Britain,"* and were fiercely denounced by Mr. Flood, passed through the Irish Parliament with a general concurrence. $\dagger$

One of the first consequences of the resolutions was a motion which was introduced by Mr. Foster, the Chancellor of the Exchequer, and carried by a large majority, imposing restrictions on the grants to manufacturers, charities, and public works, which had hitherto been lavishly and often corruptly voted, and the Parliament then imposed additional taxes, estimated to produce $f_{140,000}$ a year, for the purpose of enabling Ireland to fulfil her part of the transaction, and showing that she had no desire to evade the obligation of a contribution (Lecky's History of England in the Eighteenth Century, VI., pp. 397-398). The resolutions passed to England, and

* Froude, II., p. 462 .

† Lecky, VI., pp. 396-397 
were introduced by Mr. Pitt on February 22nd, 1785. They encountered a ficrce opposition, were denounced by North and Fox as ruinous to English trade, excited the fears of the English commercial classes, who presented petitions against them, while twelve weeks were expended in hearing the evidence of trade experts as to the pernicious effect the legislation, founded on these resolutions, would be calculated to have on English commercial prosperity. It became certain that the resolutions in their present form could not be carried in the English Parliament, and when Pitt again brought forward the scheme in May, 1785 , the original resolutions were re-digested and extended to twenty.*

The resolutions now proposed for a treaty of commerce between the two Kingdoms withdrew privileges contained in the former series of resolutions, and interposed stipulations which undoubtedly encroached on Irish Parliamentary independence. It was provided that, whatever Navigation Laws were adopted by the British Parliament, the Irish Legislature must bind itself to re-enact. "Under the terms first offered Irish trade was unrestricted by local limitation, and the East and the West Indies would have been equally open to them. Though they might still trade freely for themselves with the Dutch, Spanish, and French Colonies in the West Indies, they were allowed to re-import into England only the produce of the English West Indian Colonies, and they 'were debarred from countries east of the Cape of Good Hope,' so long as the Charter of the East India Company continued." $\dagger$ These resolutions were carried through the English House of Commons on the 2oth May, after an impassioned debate, which continued till past

$$
\text { *Lecky, VI., p. } 399 . \quad \text { † Froude, II., pp. } 477-478 .
$$


8 a.m. The opponents of the resolutions, while exciting English commercial jealousy against them, denounced them as a surrender of Ireland's Parliamentary independence. Sheridan insisted that the resolutions were a proposal on the part of the British Parliament that Ireland should upon certain conditions surrender her now acknowledged right of external legislation, and return, as to that point, to the situation from which she had emancipated herself in 1782.* "I will not," said Fox, " barter English commerce for Irish slavery-that is not the price I would pay, nor is this the thing I would purchase." + On the I2th August Mr. Orde introduced the propositions so widely altered from their original form in the Irish House of Commons. They encountered a strenuous resistance. Grattan characterised them as a revocation of the Constitution. "We are," he said, "to agree to subscribe whatever laws the English Parliament shall prescribe respecting navigation-we are to have no legislative power. Here, then, is an end to your free trade and free constitution." $\mathrm{He}$ also curiously objected that the measure was "an union, an incipient and creeping union-a virtual union establishing one will in the general concerns of commerce and navigation, and reposing that will in the Parliament of Great Britain."' Flood was in his element. "The Irish Parliament," he said, " will not become the register of the English Parliament. Freedom of the Constitution is necessary to freedom of trade. Liberty is the nurse of commerce. I will not give up an atom of it." Leave to bring in a Bill based on the resolutions was only granted, after a debate which lasted 17 hours, by 127 to 108 . This was accepted as a virtual defeat of the Government

* Whiteside's Irish Parliament, p. I 44.

$\dagger$ Lecky, VI., pp. $401-402$.

\$Whiteside's Irish Parliament, p. I 45. 
proposal. Two days after the Bill was produced. Flood moved a resolution, which was defeated by a still smaller majority, "that we hold ourselves bound not to enter into any engagements to give up the sole and exclusive right of Parliament to legislate for Ireland in all cases externally, commercially, or internally." $\mathrm{Mr}$. Orde announced that the Bill would not be pressed further. Dublin was illuminated, and the people exulted in the abandonment of the scheme.

On August $13^{\text {th }}, 1785$, the Lord Lieutenant wrote an account of the defeat to Mr. Pitt, who replied on August I 7 th, calmly and with dignity, not, however, concealing the poignancy of his feelings: "I confess myself not a little disappointed and hurt on your account by your letter and Mr. Orde's of the event of Friday. I had hoped that neither prejudice nor party could have made so many proselytes against the true interests of the country, but the die seems in great measure to be cast, at least for the present. Whatever it tends to we have the satisfaction of having proposed a system which, I believe, will not be discredited even by its failure, and we must wait times and seasons for carrying it into effect" (Ashbourne's Pitt, p. 145). The conduct of the Opposition in the British Parliament, in taking advantage, for Party purposes, of the jealousy of the Irish Parliament of all that savoured of external legislation in relation to Irish affairs, has been severely reprobated by Chief Justice Whiteside (Life and Death of the Irish Parliament, pp. 145-146), with whose views Lord Morley is in agreement. He says that the course of the (English) Opposition was factious, and, as Burke followed Fox as his leader, he found it hard to vindicate him from the

* Froude, II., pp. 477-485. I.ecky, VI., pp. 402-403. 
charge of factiousness. "For once he allowed his political integrity to be bewildered" (Edmund Burke, by John Morley, p. 125). The abandonment of the Commercial Propositions led to no complications nor friction between the Parliaments of Great Britain and Ireland. This fact assumes a present-day importance in view of the many prophecies which have been so freely and so confidently made in reference to the absolute certainty of differences in reference to commercial relations between Great Britain and Ireland under a Home Rule system, notwithstanding provisions how well devised so ever to prevent them. Mr. Lecky thus states the sequel of the rejection of the Commercial Propositions : "No positive evils appear to have followed from the rejection of the commercial propositions. Ireland, as a distinct country, continued to legislate independently for her commerce, and her Parliament did not show the faintest disposition to interfere with English commercial interests. The commercial treaty which Pitt negotiated with France in 1786 included Ireland, and it was vehemently opposed by the Whig Party in England, but, the Address approving, it was carried in Ireland without a division, and the resolutions for making the necessary alterations in Irish duties passed without the smallest difficulty. A new Irish Navigation Act, proposed by the Government, and adopting almost the whole of the English Navigation Act of Charles II., was soon after carried with equal facility (27 Geo. III., c. 23). A few years later some resolutions were moved resenting the exclusion of Ireland from the Asiatic trade, but nothing was done, and, as far as commercial matters were concerned, England had certainly no reason to distrust or complain 
of the Irish Parliament (Lecky's History of England in the Eighteenth Century, VI., pp. 404-405).

Lord Westmorland, writing as Lord Lieutenant to the English Government in 1790, thus describes the attitude of Ireland towards Great Britain in trade arrangements. "Since the failure of the propositions for a commercial intercourse between Great Britain and Ireland, no restraint or duty has been laid upon British produce or manufacture to prejudice the sale in this country, or to grasp at any advantage to articles of Irish manufacture, nor has any incumbrance by duty or otherwise been laid on materials of manufacture in the raw or middle state upon their exportation to Great Britain. At the same time in everything wherein this country could concur in strengthening and securing the navigation and commerce of the Empire, the Government has found the greatest readiness and facility. The utmost harmony subsists in the commerce of the two Kingdoms, and nothing has arisen to disturb it or give occasion for discontent.",

* Lecky, VI., p. 405. 
XVIII.

\section{THE IRISH PARLIAMENT AND THE}

\section{REGENCY QUESTION.}

The second of the great differences between the Parliaments of Great Britain and Ireland arose four years subsequent to the rejection by the Irish Parliament of the commercial propositions. As, however, the attitude of the Irish Parliament was, as in the former case, based on a jealous care for its supremacy, and an intolerance of all approach to subordination to the English Parliament, an account of this incident may, by anticipation in the order of events, be given in immediate sequence to the sketch of the history of the commercial propositions. Mr. Grattan, who was on terms of the closest personal and political intimacy with the leaders of the Whig Opposition in Great Britain, had visited England in 1788 , and was at Chester on his way home to Ireland in the October of that year when he was overtaken by a message which recalled him instantly to London. King George III. had been wholly deprived of reason, had been placed under restraint, and Parliament, which had been prorogued till the 2oth November, could not be opened, nor the causes of summons declared in a speech from the Throne, formalities always held to be essential to enable Parliament to proceed with its legislative business. The Irish Parliament had been prorogued till the $5^{\text {th }}$ February, 1789. Grattan had 
accordingly ample time to return to London and watch the proceedings rendered necessary for the conduct of public business in England in the case of the mental incapacity of the sovereign, a contingency for which no provision had been made by law, with a view to the guidance and direction of public affairs in Ireland on the meeting of the Irish Parliament. On the 2oth November both Houses of the English Parliament assembled, but agreed, under the circumstances, to adjourn for a fortnight, all members being summoned by circular letters to attend at the next meeting of the Houses to which they respectively belonged. Then, although Parliament, without being summoned by the Crown, had no authority to deal with any business whatever, it, owing to the necessity of the occasion, proceeded to deliberate on the questions to which the King's illness gave rise. It was admitted by Pitt that the moral claim of the Prince of Wales to exercise the office of Regent was overwhelming, but that Parliament had a right to select a Regent and to define and limit his powers. Fox, on the other hand, maintained that the English monarchy being hereditary and not elective, and the eldest son of the King being of age, he had a right to enter into the full exercise of the royal power during the incapacity of his father, but that the two Houses of Parliament, as the organs of the nation, were alone entitled to pronounce when the Prince ought to take upon himself this power. Pitt met Fox's claim of right by proposing and carrying a resolution that it was the duty of the Lords and Commons to provide a substitute pending the incapacity of the Sovereign. If the Prince, according to the theory of Fox, had an inherent right to assume the royal power in all its plenitude, it was a simple thing for the two Houses 
to carry an address inviting him to do so. But if limitations were to be imposed it could only be done by Act of Parlianent, and no Act of Parliament could exist without the Royal Assent. The proposal was accordingly made that a Commission should be appointed by the two Houses for the purpose of keeping the Great Seal, the impress of which was the formal expression of the King's Assent; that this Commission might bo presumed to act as the representative and by the direction of the King, and that under this fictitious authority it might affix the Great Seal and give validity to the Regency Bill. This plan, which was described as a "phantom" of Royalty, a "fiction," and a " forgery," was adopted, as there appeared to be no other way of limiting the Regency, by large majorities in the British Parliament (Lecky's History of England in the Eighteenth Century, VI., pp. 416-4I8). "The simplest and most direct course," writes Sir Erskine May, "would undoubtedly have been for both Houses to agree upon an address to the Prince of Wales praying him to exercise the Royal authority, subject to conditions stated in the address itself, and on his acceptance of the trust to proceed to give legal effect to these conditions by a Bill to which the Royal Assent would be signified by the Regent on behalf of the Crown. Either in earlier or later times such a course would probably have been followed. But at that period, above all others, lawyers delighted in fiction, and Westminster Hall was peopled with legal phantoms of their own creation " (May's Constitutional History of England, I., pp. 191-192). Grattan remained in London till January, when the establishment of the Regency, which would have been immediately followed by a change of Government, with Fox as Prime Minister, was thought 
to be a question of days. He had received an assurance of the recall of the Irish Lord Lieutenant, Lord Buckingham, who had made himself very unpopular, and that his measures of reform should not be opposed by the incoming Government, while he in turn had undertaken that the Irish Parliament would elect the Prince of Wales Regent, dispensing with the ungenerous restrictions with reference to dealings with royal property, granting of offices for life and creation of peerages, and acknowledging Fox's views of his position. The Lord Lieutenant was well aware of the sensibilities of the Irish Parliament with reference to its own powers. On November 23rd, I 789 , in a " most secret " letter to the Cabinet, he warned them of the extreme jealousy which might be looked for in the most loyal hearts if England should appear to encroach on their Constitution by dictating their action, while he, at the same time, assured them that "any measures taken in England would be adopted without difficulty."* On January 29th, 1789, a few days before the meeting of the Irish Parliament, the Lord Lieutenant took a widely different view of the situation. "I have very little hope," he writes, "to be able to stem, on

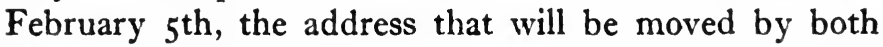
Houses to His Royal. Highness to take upon himself the Regency of this Kingdom." When Parliament met, a motion to postpone the question till the English Parliament had decided on the Regent was rejected by 128 to 74 . The plan of proceeding by Bill, which was proposed by the Government, was rejected, and, after a long debate, and chiefly under the guidance of Grattan, who utterly denied that an English Regent made by an English Statute could have any authority in Ireland

* Froude, II., p. $54^{\circ}$. 
unless he was also made Regent by the Irish Parliament, and contended that limitation of the power of a Regent was an attack on the King of Ireland, both Houses agreed to address the Prince of Wales to take upon himself " the government of this nation during the continuance of His Majesty's present indisposition, and no longer, and under the style and title of Prince Regent of Ireland, in the name and on behalf of His Majesty, to exercise and administer, according to the laws and constitution of this Kingdom, all regal powers, jurisdiction, and prerogatives to the Crown and Government thereto belonging."* In the House of Commons the Government attempted no division. In the House of Lords the resolution was carried by a large majority, 45 contents, 26 non-contents. $\dagger$ The address was carried by the two Houses to the Lord Lieutenant on the following day for transmission to the Prince. The Lord Lieutenant refused to receive the Roll. "Under the impression," he said, " which I feel of my official duty, and of the oath which I have taken as Chief Governor of Ireland, I am obliged to decline transmitting this address into Great Britain. I cannot consider myself warranteci to lay before the Prince of Wales an address purporting to invest His Royal Highness with power to take on him the government of this realm before he shall be enabled by law to do so." + Mr. Grattan moved that the Lord Lieutenant, having refused to transmit the address to the Prince, a deputation should be chosen from the Lords and Commons to carry it over, and this being assented to, he proposed next a formal resolution that, in addressing His Royal Highness, the Parliament of Ireland had exercised an undoubted right. Grattan moved and

*Lecky, VI., pp. 419-420. †Froude, II., p. 549. †Froude, II., p. 550. 
carricd yet another resolution, that Lord Buckingham's refusal to submit the address was "ill advised and unconstitutional." A similar resolution was passed by the House of Lords. In order to secure that Parliament should be sitting during the continuation of the case, the chief supplies were only granted for two months, and the two Houses appointed six Commissioners, including the Duke of Leinster and Earl Charlemont, to present the address. They went to England and discharged their task, but at this critical moment the recovery of the King put an end to the question that was pending." The Prince of Wales, in reply to the address, having thanked the Parliament of Ireland for their loyalty and affection, stated that he trusted the King would soon be able to resume the personal exercise of Royal authority which would render unnecessary any further answer except a repetition of his thanks.

This collision between the British and the Irish Parliaments on the Regency question was made one of the pretexts of the Union. It was always an acknowledged principle of the Irish Constitution that whoever is King de facto in England is King de jure in Ireland. A Bill, when the measure of the Union was in progress, was introduced by the Anti-Unionists to enact that whoever was Regent de facto in England should be Regent de jure in Ireland. Lord Castlereagh, on the part of the Government, opposed it. He did not wish the difficulty to be obviated. With reference to this Bill, Lord Cornwallis, the Lord Lieutenant of the Union, writing to the Cabinet, mentions " several possible cases of difficulty between the British and the Irish Cabinets which Lord Castlereagh

*Lecky, VI., pp. 428-429. Froude, II. pp. 550-555.

† May's Constitutional Histery of England, I., pp. 194-I95. 
will urge. And as many possibilities of this kind may be stated, Lord Castlereagh will endeavour to insinuate that the only complete measure for putting an end to the difficulties which arise from the present situation in Ireland is a Parliamentary Union" (Castlereagh Correspondence, II., p. I8I). Professor Dicey is of opinion that this Regency question "had been treated as possessing more importance than from a constitutional point of view belonged to it" (Case of England against Home Rule, page 222). Mr. Lecky, in one of his earliest works, says: "The difference which arose between the English and the Irish Parliaments concerning the Regency was undoubtedly a very serious embarrassment, but its constitutional importance has been greatly exaggerated " (Leaders of Public Opinion in Ireland, p. 190). To this view he adheres with a more matured judgment. "I am entirely unable," he writes in 1887 ; " to concur with those who have represented the action of the Irish Parliament as seriously endangering the connection. It is quite certain that nore of the leading actors in Ireland was disloyal to that connection, and it appears to me to be absurd to suppose that a measure, investing the acknowledged heir of the British Throne with regal power in Ireland during the incapacity of his father, should have tended to produce a permanent separation of the two countries. It was constantly repeated that under the Constitution of 1782 the hereditary monarchy was the sole bond of union, but in the difference between the two Parliaments it was the Irish Parliament which most exalted the principle of heredity, which was most anxious to preserve the executive power unimpaired in its prerogatives, and which formed the most modest estimate of the capacity of Parliament. It was morally certain 
that the same Regent would preside over both countries, though with slightly different powers. It is probable that if the Regency had continued, a change of Ministers would, in both countries, have placed the executive and legislative powers in harmony. In the worst case, either the death or the recovery of the King, or a turn in his illness which made his recovery hopeless, would have replaced the two nations in their former relation, and an express enactment might then have been easily made preventing the possible recurrence of a difficulty which was serious only because it was unprovided for by law" (Lecky's History of England in the Eighteenth Century, VI., pp. 427-428). Two great English lawyers have placed on record their well-considered judgments that in the Regency question the course adopted by the Irish Parliament, in contrast with the action of the British Parliament, was in accordance with the spirit of the Constitution. Lord Campbell, who filled the position of Lord Chancellor of Ireland, Lord Chief Justice, and Lord Chancellor of England, writes: "After the consideration I have repeatedly given to the subject, I must ever think that the Irish Parliament proceeded more constitutionally by considering that the heir apparent was entitled to exercise the Royal authority during the King's incapacity, as upon a demise of the Crown, and by presenting an address to him praying him to do so, instead of arrogating to themselves, in Polish fashion, the power of electing the supreme magistrate of the Republic, and resorting to the palpable lie of the proceeding being sanctioned by the afflicted Sovereign" (Lord Campbell's Lives of the Lord Chancellors, IX., p. 185). Lord Brougham, another Lord Chancellor of England, writing in $\mathbf{1 8 6} \mathbf{1}$, in his closing years, says : 
" Of all the sovereign's attributes none is more important than his independent and hereditary title, nor can a greater inroad be made upon the fundamental principles of the Constitution than the bringing of this into any doubt or any jeopardy. Hence, in the event of his infancy, illness or other incapacity, it is a serious defect in the system that no ground has been provided for supplying his place, because this leaves the question to be discussed and debated each time that the Royal Authority fails, and in the midst of all the passions sure to be engendered by the adherents of contending parties and the advocates of conflicting opinions. There can be no manner of doubt that Mr. Fox's opinions (on which the Irish Parliament acted) in 1788 were more in accordance than those of Mr. Pitt with the spirit of a Constitution which abhors all approach to election in the appointment of the Chief Magistrate " (Brougham's British Constitution, pp. 262-263). 


\section{XIX.}

\section{'I'HE AGITATION FOR PARLIAMENTARY REFORM AND THE REMOVAL OF CATHOLIC DISABILITIES.}

THE jealousy of external influence manifested by the Irish Parliament on two memorable occasions-the questions of the Commercial Propositions in 1785 and of the Regency in 1789 -seems curious to the historian who is aware of the composition of the Irish House of Commons ; the relations of that House to the House of Lords, by whose Members so many of the representatives of the nomination boroughs were returned, and of the hostility of the Irish Parliament to a comprehensive measure of reform which would have rendered it truly representative of the country, and an exponent of its wants and wishes. The dissolution of the Volunteer Convention in 1783 , with an Irish Parliament still unreformed, rendered the Union possible. Mr. Lecky has well said that the experience of all countries shows that a monopoly of power as complete as that which was possessed by a small group of borough owners in Ireland is never, or scarcely ever, broken down except by measures bordering on revolution; that while the great Catholic population were wholly unrepresented in the Irish Parliament, the Protestant yeomen of the north and the great bulk of the Protestant gentry found them- 
selves either unrepresented or most inadequately represented-classes which combined most of the intelligence and a great preponderance of the property of the country. (See Lecky's History of England in the Eighteenth Century, VI., p. 348.)

"The accumulation of borough interests at the disposal of the Treasury, and the habitual custom of 'supporting the King's Government,' gave the Government, on nearly all occasions, an overwhelming strength in the Irish Parliament, while the majority had certainly no desire to carry any measure of reform which would alter their own very secure and agreeable position, or expose them to the vicissitudes of popular contests" (Lecky's History of England in the Eighteenth Century, VI., p. 37r). The system of corruption " enabled a small oligarchy to resist the most earnest and most legitimate demands of Irish opinion, and, as Grattan vainly predicted, it taught the people to look elsewhere for their representatives, and exposed them to the fatal contagion of the revolutionary spirit that was then circulating through Europe" (Lecky's History of England in the Eighteenth Century, VI., p. 443). On the question of granting the suffrage to the Catholics, the Ministers in England were in favour of concession, being deeply influenced by the war in revolutionary Europe against the Catholic faith, which stood for reverence for law and stability of institutions, while the administration in Ireland, largely influenced by the corruptionist ascendancy and borough-mongering party, were opposed to such concessions, which they feared would go hand in hand with Parliamentary Reform and the abatement of class privilege and monopoly. To both the British Cabinet and the Irish Administration the overtures made by the 
revolutionary Protestants in the North to the Catholics scemed very alarming. After the dissolution of the Convention a very serious agitation began. A correspondent, writing to Lord Charlemont, says that a rage for supporting the Convention has seized on the Yeomanry. The Bishop of Derry urged the Volunteers to make the political emancipation of the Catholics their first object. The Government, for a time, contemplated the possibility of prosecuting him. Pitt, writing on August 2oth, 1784 , to Orde, the Irish Secretary in the Duke of Rutland's Viceroyalty, says : “ The madness of the Bishop of Derry, though certainly not innocent, has not yet, I think, reached the legal guilt of such magnitude as to admit of any vigorous or decisive proceedings. I am clear, as I am persuaded you are, that no blow should be menaced till it can be struck." Mr. Pitt then, in the next sentence, shows that he is not unfamiliar with Castle methods of government. "I hope," he says, " you will be as successful as you expect in interesting the oracles of modern timesthe newspapers-in your favour. Though not the most glorious, they are, I am sure, both here and in Ireland, the most effectual, and, perhaps, both the cheapest and most harmless engines that Government in such circumstances can employ" (Ashbourne's Pitt, pp. 80-81).

Soon after the Convention episode the Bishop of Derry left Ireland on the plea of ill-health, and spent the remaining years of his life in Italy, where he died in 1803. He on one occasion only interfered in Irish politics by writing a letter in 1800 in favour of the Union. The rejection in 1784 , and again in 1785 , of Flood's measure for reform in the Irish Parliament showed that in the Irish Parliament, if unaffected from without, there 
was little hope that progress in this direction could be made. The Corporation drew a petition to the King complaining that the Reform Bill had been denied a hearing, and imploring that the penal laws which oppressed the Roman Catholics should be abolished. The Lord Lieutenant, while complying with the request that the petition should be transmitted to the Throne, stated that he would convey to the King his entire disapprobation of it.* Fitzgibbon, by a strained and unusual construction of law, treated the conduct of Mr. Hugh Reilly, High Sheriff of Dublin, in summoning a meeting to elect delegates for a Reform Congress, as a contempt of the Court of King's Bench, proceeded against him by " attachment," and, without the intervention of a jury, caused him to be condemned to a small fine. Pitt took a serious view of this zeal beyond the law. "The business of the County meeting," he writes to Orde on August 20th, 1784, "you will, I am sure, have attended, is an object of great delicacy. It seems to me, on the one hand, necessary to cherish the spirit of any friends of Government who will stand forth, and not to give the friends to disorder any advantage by encouraging anything that can be construed into an attack on the legal rights of petitioning" (Ashbourne's Pitt, p. 80). Again, in another letter to Orde, January 12 th, 1785 , Pitt refers to this incident : "I think it a matter of great delicacy and caution, and enough has been done already" (Lecky's History of England in the Eighteenth Century, VI., p. 365). The House of Commons supported Fitzgibbon's view, which was challenged by Flood and Curran, by a majority of two to one. Erskine, who was consulted on the subject, wrote a 
remarkable letter, in which he asserted that the conduct of the King's Bench Judges would justify their impeachment, and that the precedent, if acquiesced in, would be fatal in the highest degree to liberty in both countries. In July, 1784 , an address in favour of Parliamentary reform and the extension of the franchise to Catholics was presented to Lord Charlemont by the Ulster Volunteers in Belfast, but he, while expressing himself in favour of Parliamentary reform, pronounced himself strongly against Catholic suffrage.* 'The nature of the petitions for Reform may be gauged from a petition which came from Belfast in 1784 . It stated "that the majority was illegally returned by the mandates of Lords of Parliament and a few great Commoners, either for indigent boroughs where scarcely any inhabitants exist, or for considerable towns where the elective franchise is unjustly confined to a few .... that the House of Commons is not the representative of a nation, but of mean and venal boroughs; that the price of a seat in Parliament is as well ascertained as that of the cattle in the fields, and that although the united voice of the nation had been raised in favour of substantial reform, yet the abuse lying in the very frame and disposition of Parliament itself, the weight of corruption crushed with ignominy and contempt the temperate petitions of the people." Under these circumstances, said the petitioners, the repeated abuses and perversion of the representative trust amounted to a virtual abdication and forfeiture in the trustees, and they had summoned " a civil convention of representatives to be freely chosen by every county, city, and great town in Ireland .... with authority to determine in the name of the collective body on such

$$
\text { * Lecky, VI., p. } 364 \text {. }
$$


measures as are likely to establish the Constitution on a firm and permanent basis." They accordingly asked the King to dissolve Parliament and to "give efficacy to the determination of the convention of actual delegates either by issuing writs agreeably to such plan of reform as shall by them be deemed adequate, or by co-operating with them in other steps for restoring the Constitution " (Lecky's History of England in the Eighteenth Century, VI., pp. 365-366). The Congress, however, which met in October, 1784 , and again in November, 1785 , was not a success. The Catholic question divided the members, and little resulted from the Congress except some declamatory addresses in favour of Parliamentary reform.

Grattan, who, as we have seen, co-operated with Flood in 1784 , and again in 1785 , in his unsuccessful efforts for Parliamentary reform, was himself, with his immediate following, disposed to devote an undivided energy to the active reform of Parliament. His proposals were of the most moderate character. "A 'Place Bill,' limiting the number of placemen who sat in the House of Commons, copied from that which had existed for more than eighty years in the English Statute Book; a Pension Bill, limiting the number of pensioners; a Responsibility Bill, giving additional guarantees for the proper expenditure of different branches of the Revenue, and a Disfranchisement of income and custom house officers, like that which had been carried in England under Rockingham, would, at this time, have met Grattan's demands, but all these measures were steadily resisted." (See Lecky's History of England in the Eighteenth Century, VI., p. 387.) In March, 1786, it was stated that the Pension List amounted to $f 100,000$ per annum. Grattan wound up his speech by the declaration that if he should 
affirm the Pension List was not a grievance, he would " affirm, in the face of his country, an impudent, insolent, and public lie." It was in this debate that Curran uttered his celebrated denunciation of the Pension List as " that polyglot of wealth, that museum of curiosities, which embraces every link in the human chain, every description of men, women, and children, from the exalted excellence of a Hawke or a Rodney to the debased situation of a lady that humbleth herself that she may be exalted" (Froude's English in Ireland, II.,pp. 504-505). In I $79^{\circ}$ the House of Commons was told in language of exquisite directness that the Constitution of 1782 was wholly ineffective so long as Parliament itself remained unreformed and subject to corrupt influence. "The acquisitions of 1782 ," said Sir Lawrence Parsons, " freed this country from external power, but not from internal machination. On the contrary, this country has been governed worse since then than it ever was before, and why? Because of those very acquisitions. . . . . It has been the object of English Ministers ever since to counteract what we obtained at that time and to establish a surreptitious and clandestine influence for the open power which the English Legislature was thus obliged to relinquish."* The French Revolution affected Irish politics just as the War of the American Independence ten years previously had affected Irish politics. In 1791 the anniversary of the French Revolution was celebrated at Belfast with great enthusiasm, and in September of that year Wolfe Tone published his pamphlet, under the signature of "A Northern Whig," urging Parliamentary reform through the exertions of the Roman Catholics and the Presbyterians working

$$
\text { *Iecky, VI., p. } 460 \text {. }
$$


together.* In Cctober, 1791, Wolfe Tone founded in Belfast the first Society of United Irishmen, which consisted of thirty-six original members, and was intended to aim at "an equal representation of all Irishmen." Very soon a branch of this Society was established in Dublin. The Society was originally constituted for the purpose of forming a political union of Protestants and Catholics, and thus obtaining a liberal measure of Parliamentary reform. Wolfe Tone's reform scheme, which embodied the proposal that Ireland should be divided into 300 equal electoral divisions, each returning one member, with universal suffrage, payment of members, and annual Parliaments, was widely different from Grattan's mild Reform programme-a programme based on the assumption " that the Constitution of Ireland was essentially a good one, and might be amended without subverting any of its fundamental principles." Tone made no secret of his contempt for Grattan's Reform Party. "They are not," he wrote, " sincere friends to the popular cause; they dread the people as much as the Castle does." $†$.

The birth of the United Irish Movement, with its aim of obtaining a reform of Parliament of the most comprehensive character, was signalised by the rise in the Catholic Committee of a party headed by John Keogh, a Dublin tradesman, who determined that the Catholic Cause would be more effectually promoted by demands couched in precise language and backed by the people at large than by the gentler and more diplomatic measures of the Catholic Bishops, noblemen, and landed gentlemen who had previously directed the Catholic agitation. Several circumstances were conspiring to make this

$$
\text { *Lecky, vI., pp. 462-463. † †ecky, VI., pp. 465-468. }
$$


party ascendant in the Catholic Committee. "Towards the close of 1790 the Catholic Committee waited on Major Hobart, the Chief Secretary in Lord Westmorland's Viceroyalty, requesting him to support a petition to Parliament which asked for nothing specific, but simply prayed that the case of the Catholics should be taken into consideration, but their request was refused, and they could not find a single member to present their petition to Parliament. In the course of the same year an address of loyalty, intended to be presented to Lord Westmorland by the Catholics on the occasion of a visit of the Lord Lieutenant to Cork, was returned to them because it concluded with a hope that their loyalty would lead to a further relaxation of the Penal Code. In the beginning of 1791 a deputation from the Catholic Committee went to the Castle with a list of the Penal Laws which they were anxious to have modified or repealed, but were dismissed without even the courtesy of an answer." (See Lecky's History of England in the Eighteenth Century, VI., pp. 472-473.) The members of the Catholic Committee, who were reluctant to any course transgressing the limit of deference and obedience to authority, headed by Lord Kenmare, viewed with great aversion the tendency of Catholics to unite with Presbyterians of the revolutionary school of politics for the purpose of achieving Parliamentary reform in which Catholic emancipation would be included, and seceded from the Catholic Committee when defeated in a proposal that the extent of the future relaxations of the Penal Code should be left wholly to the Legislature. In October, 1791, the month of the founding in Belfast of the Society of the United Irishmen, the Catholic Committee issued a declaration demanding in strong terms 
a complete abolition of all parts of the Penal Code. They shewed their conviction that the Irish Administration was determined to make no concession, with reference to the removal of Catholic disabilities, of their own free will, by sending in January, 1792 , a deputation to England to lay their petition before the Throne (Lecky's History of England in the Eighteenth Century, VI., pp. 476-477). The attitude of the Catholic Church in the revolutionary war, the fact that, by Mitford's Act in I791, English Catholics who took the oath provided by the Statute were relieved from all the laws against recusancy, were restored the full rights of celebrating their services and educating their children, were admitted to be barristers, solicitors, clerks and notaries, and freed from petty and vexatious restrictions-above all, the fear that Irish Catholics, alienated by denial to them of their just demands, might make common cause with the revolutionaries-all powerfully contributed towards the adoption by the Cabinet of a friendly attitude on the subject of Irish Catholic claims.* On October 20th, I79I, Lord Grenville wrote to Lord Westmorland : "I cannot help feeling a very great anxiety that such measures may be taken as may effectually counteract the union between the Catholics and the Dissenters, at which the latter are evidently aiming. I may be a false prophet, but there is no evil I would not prophesy if that union takes place at the present moment, and on the principles on which it is endeavoured to bring it about." $\dagger$ The English Cabinet, in deference to the remonstrances of Lord Westmorland and Major Hobart, who were terrorised by the prophecies of the friends of the Government, as the borough-mongers termed themselves,

$$
\text { *Lecky, VI., p. } 479 \text {. † Lecky, VI., p. } 484 .
$$


abandoned their first scheme of extending in 1792 the suffrage to the Roman Catholics, although they were careful to impress on the Lord Lieutenant and his Secretary that there must be no pledge as to the future conduct of the Government on the Catholic question. "Any pledge," wrote Pitt to Westmorland on June 29th, 1792, " against anything more in the future seems to me to be in every view useless and dangerous, and it is what on such a question no prudent Government can concur in. I say nothing on the idea of resisting all concession, because I am in hopes there is no danger of that line being taken. If it were, I should think it the most fatal measure that could be contrived for the destruction ultimately of every object we wish to preserve."*

That the concession of the franchise to the Roman Catholics in 1792 could have been made without the expense of a great social and political convulsion predicted by the Irish Government, is proved by the fact that the concession of the Catholic franchise was carried without the smallest difficulty in 1793 , and that nothing but the recall of Lord Fitzwilliam in 1795 prevented the admission of Catholics into the Irish Parliament in that year. Although the Irish Government, which had placed itself completely in the hands of the corruptionist and ascendancy faction, could not, having regard to the decided wish of the British Cabinet, prevent the introduction of the Relief Bill in 1792, they succeeded in greatly limiting its provisions, and in depriving it of the grace and authority of a Government measure. It was seconded, indeed, by Hobart, but it was introduced by Sir Hercules Langrishe, a private member, though a steady

$$
\text { * Lecky, VI., p. } 500 .
$$


supporter of the Government. It enabled the Catholics to be attorneys, solicitors, notaries and attorneys' clerks, and to practise at the Bar, though they could not rise to the position of king's counsel or judge. It repealed the laws prohibiting barristers from marrying Catholics, and solicitors from educating their children as Catholics, the laws of William and Anne against the intermarriage of Catholics and Protestants, the obsolete Act against foreign education, and the equally obsolete clause of the Act of 1782 which made the licence of the ordinary necessary for Catholic schools, and, finally, it removed all restrictions on the number of apprentices perinitted to Catholic trade. "The concessions fell far short of the Catholic expectations, but the ascendancy spirit, which had been evoked, stimulated, and supported by the Administration, now rose very high. A petition of the Catholics asking for some share of the elective franchise, and a petition of the Protestant United Irishmen of Belfast asking for the repeal of all the anti-Catholic laws, were received at first by the House of Commons, but after they had been laid on the table they were rejected by large majorities" (Lecky's History of England in the Eighteenth Century, VI., pp. 503-504). The Catholic Committee did not permit feelings of irritation and disappointment to get the better of cool judgment. "They endeavoured to allay the ferment by publishing a declaration of belief, similar to that which had lately been published in England, abjuring some of the more obnoxious tenets ascribed to them and corroborated by opinions of foreign Universities, and they also published in February, 1792, a remarkable address to the Protestants, denying formally that their application for relief extended to unlimited and total emancipation, and that 
their applications had ever been made in a tone of menace." They asked only, they said, for admission to the profession and practice of the law, for capacity to serve as county magistrates, for a right to be summoned and to serve on grand or petty juries, and for a very small share of the county franchise. They desired that a Catholic should be allowed to vote for a Protestant county member, but only if, in addition to the forty-shilling freehold, which was the qualification of the Protestant voter, he rented and cultivated a farm of $£, 20$ a year, or possessed freehold of that value. The disfranchisement of the Catholic farmers was, it was said, a most serious practical grievance, for, in the keen competition for political power which had arisen since the Octennial Act, and still more since the Declaration of Independence, landlords, in letting their farms, constantly gave a preference to tenants who could support their interests at the hustings. Catholic leaseholders, at the termination of their leases, were continually ejected in order to make room for voters, or they were compelled to purchase the renewal of their leases on exorbitant terms (Lecky's History of England in the Eighteenth Century, VI., pp. 504-525). They, moreover, issued a circular letter inviting the Catholics in every parish in Ireland to choose electors, who, in their turn, were in every county to choose delegates to the Catholic Committee in Dublin, in order to assist in procuring " the elective franchise and an equal participation in the benefits of trial by jury." This step excited the greatest alarm in Government circles, and the grand juries in most of the counties passed resolutions strongly censuring it, but its legality was considered to be unquestionable (Lecky's History of England in the Eighteenth Century, VI., pp. 505-506). 
So far back as November I8th, 1792, we find Mr. Pitt contemplating whether the admission of the Catholics to the franchise might not be utilised for the destruction of the Irish Parliament. "The idea," he writes to the Lord Lieutenant, " of the present fermentation, gradually bringing both parties to think of an union with this country, has long been in my mind. I hardly dare flatter myself with the hope of its taking place, but I believe it, though itself not easy to be accomplished, to be the only solution for other and greater difficulties. The admission of Catholics to a share of the franchise could not then be dangerous. The Protestant interest, in point of power, property, and Church establishment, would be secure, because the decided majority of the supreme Legislature would necessarily be Protestant, and the great ground of argument on the part of the Catholics would be done away with, as, compared with the rest of the Empire, they would become a minority. You will judge where and to whom this idea can be confided. It must certainly require great delicacy and management, but I am heartily glad that it is at least in your thoughts" (Lecky's History of England in the Eighteenth Century, VI., p. 5I3). The Lord Lieutenant writes to Mr. Pitt on November 24th, I792: "The Protestants frequently declare that they will have a Union rather than give the franchise to the Catholics; the Catholics that they will have a Union rather than submit to their present state of degradation. It is worth while turning in your mind how the violence of both parties might be turned on this occasion to the advantage of England " (Lecky's History of England in the Eighteenth Century, VI., p. 529).

The successes of the French Revolution had powerfully affected the situation in Ireland. In July a great 
meeting of Volunteers and inhabitants of Belfast voted unanimously an address to the French Nation congratulating them on the capture of the Bastile, and also an address in favour of Catholic claims (Lecky's History of England in the Eighteenth Century, VI., pp. 535-536). The Catholic Convention met on December 3 rd, 1792. In October twenty-two counties and most of the cities had already elected delegates according to the prescribed form, and the other counties in a more irregular way, and instructed them to maintain "guarded language, but to petition for the elective franchise and trial by jury." The proceedings of the Convention were loyal and moderate, but it showed its sense of the hostility of Dublin Castle to its objects by petitioning the King directly, five delegates, including Keogh and Byrne, being selected to present the petition. The Catholic Convention with great prudence declined to receive a deputation of the United Irishmen. The Lord Lieutenant in his communications with Pitt admits that Protestant opinion was not altogether hostile to Catholic claims. "Every step," he writes, "of conciliating the two descriptions of people that inhabit Ireland diminishes the probability of that object to be wished-a Union with England. Before the present panic it was a good deal in the thoughts of the people as preferable to being overwhelmed by the Catholics, as Protestants termed concessions, or continuously slaves in the Catholic phrase. That conversation, since Protestants have been persuaded that England either could or would not help them, has subsided" (Lecky's History of England in the Eighteenth Century, VI., pp. 548-549). The Convention, although they did not admit the United Irish deputation, passed a warm vote of thanks to Belfast; they determined, contrary to 
their first intention, not to restrict the petition to votes or juries, but to ask a full admission to all the rights and privileges of the Constitution, and they sent the delegates, who carried the petition to London, by way of Belfast (Lecky's History of England in the Eighteenth Century, VI., p. 550).

"The temper of the people," writes Westmorland to Pitt on December 18th, 1792, " with exception to our leading Cabinet friends, is grown much more conciliatory." On December 17th, 1792, Dundas, on behalf of the British Cabinet, directs the Lord Lieutenant " to hold a language of conciliation " towards the Catholics, and he announces his positive conviction that " it is for the interest of the Protestants of Ireland, as well as the Empire at large, that the Catholics, if peaceable and loyal, should obtain participation on the same terms with Protestants in the elective franchise and the formation of juries." The Lord Lieutenant deferred to the direction of the British Cabinet, and stated that he would endeavour to carry out their views, a course not unattended with risk, but "the circumstances of Europe, which have their effect in this country, make such a risk expedient, and perhaps unavoidable" (Lecky's History of England in the Eighteenth Century, VI., p. 556). The intended speech from the Throne, as sent over to England, contained no allusion to the Catholics, but the English Ministers inserted a clause in their favour and peremptorily enjoined that it should be read. The Session of I793, which opened on January Ioth, was signalised by a warlike speech from the Throne, which contained the following paragraph which had been inserted in England : "I have it in particular command from His Majesty to recommend it to you to apply yourselves to the con- 
sideration of such measures as may be most likely to strengthen and cement a general union of sentiment among all classes and descriptions of His Majesty's subjects in support of the established Constitution; with this view His Majesty trusts that the situation of His Majesty's Catholic subjects will engage your serious attention, and in the consideration of this subject he relies on the wisdom and liberality of his Parliament." The address was moved in the House of Commons by Lord Tyrone, and seconded by Mr. Arthur Wesley, as the name is always spelt in the Irish Parliamentary Reports, subsequently as Duke of Wellington, the Prime Minister of the Catholic Emancipation era. There was no division on the Address, and an amendment moved by Grattan, thanking the King for " taking a leading part in healing the political dissensions of his people on account of religion," was carried unanimously.* The fact of the Irish Government favouring a policy to which they expressed themselves as utterly opposed a year previously, and to which they had not changed their personal hostility, and presenting that policy without fear of defeat to the same House of Commons who, in the last Session, had refused to entertain it and had orderec a perfectly respectful petition in its favour by an immense majority to be removed from the table, presents an object lesson of the Irish Parliament as a parody of a representative institution as we understand the term under a system of responsible Government. Mr. Hobart, the Irish Secretary, thus accounts for this astonishing change of front, which would be unthinkable in a Government which retained its position, and in the same House of Commons, according to the constitutional practice which now obtains and has been long established: "Conces-

$$
\text { * Lecky, VI., pp. 561-563. }
$$


sions to the Catholics," he writes, "will certainly be acceded to by all parties to an extent which last year nothing would have effected, but it is perfectly understood that the concession has become irresistible by the encouragement which has been given in England and promoted by the success of the French arms and probability of war. French or levelling principles have been reprobated by every man who has spoken in the House of Commons, and every expression of loyalty, conveyed in the strongest terms by Mr. Grattan particulariy, whose praises of the monarchial part of the Constitution can only be equalled by his desire to cripple the Executive Government" (Lecky's History of England in the Eighteenth Century, VI., p. 564).

On February $4^{\text {th }}$, Hobart moved for leave to bring in his Catholic Relief Bill, and stated the nature of its provisions. It was of a kind which only a year before would have appeared utterly impossible. "He proposed to give Catholics the franchise both in towns and in country on exactly the same terms as Protestants, to repeal the laws which still excluded them from grand juries, except when there was not a sufficient number of Protestant freeholders, and from petty juries in a cause between Protestants and Papists; to authorise them to endow colleges, universities, and schools, and to obtain degrees in Dublin University, and to remove any provisions of the law which might still impose disabilities upon them respecting personal property. He proposed, moreover, to enable them to become magistrates, to vote for magistrates in corporations, and to carry arms, subject, however, to a property qualification. They were also, with the concurrence of the English Government, to be admitted to bear commissions in the Army and 
Navy, and, with a few specified exceptions, all civil offices were to be thrown open to them." * This great and comprehensive measure passed through Parliament almost entirely unmodified and without any serious opposition. The clause giving unlimited franchise to Catholics, which was most contested, was carried by I4I to $72 . \dagger$ A motion to introduce into the Government Bill a clause admitting Catholics to Parliament was proposed by Mr. George Knox and seconded by Major Doyle, who claimed to have been the earliest advocate in Parliament of complete emancipation, which he recommended in a speech in the debate on Flood's Reform Bill in 1784 , in which he objected to any Parliamentary Reform in Ireland which excluded Catholics as wholly inconsistent and insufficient. Mr. Knox's proposal was defeated by 163 to 69 , the whole might of the Government being thrown against him. Mr. Arthur Wesley, the future Duke of Wellington, was put forward as the chief opponent of the proposal. "It would be curious," writes Mr. Lecky, " to know whether Wellington remembered this speech in 1829 , when the unsettled question of Catholic Emancipation had brought Ireland to the verge of civil war, when the agitation it aroused had ranged the main body of the Irish Catholics under the guidance of demagogues and priests, and had given a death-blow to the political influence of the landlords over their tenantry, and when he was himself obliged to set the fatal example of yielding to the fear of rebellion a measure which he had pledged himself to oppose. If the Catholic question had been settled in 1793 , the whole subsequent history of Ireland would have been changed. The rebellion of 1798 would almost certainly either have never taken place, or have been confined to an

$$
\text { *Lecky, VI., p. } 566 . \quad \dagger \text { Lecky, VI., p. } 567 .
$$


insignificant disturbance in the North, and the social and political convulsions which were produced by the agitations of the present century might have been wholly or in a great measure averted" (Lecky's History of England in the Eighteenth Century, VI., p. 575). The Catholic Relief Bill received the Royal Assent in April, I793, and in the same month the Catholic Convention dissolved itself. Before doing so it passed a resolution recommending the Catholics to co-operate in all loyal and constitutional means "to obtain Parliamentary reform." *

Against a Reform Bill, however, the Cabinet was firm. The question was brought before the House of Commons by Grattan and Ponsonby. Hely-Hutchinson, in the course of debate, gave in a short compass the genuine state of Parliamentary representation at the time, which is of great historic interest, and is incorporated in another part of this work. The Government, however, carried without difficulty an evasive amendment, asserting " that under the present system of representation the privileges of the people, the trade and prosperity of the country have greatly increased, and that if any plan be produced likely to increase these advantages and not hazard what we already possess, it ought to be taken into the most serious consideration" (Lecky's History of England in the Eighteenth Century, VI., p. 598).

It was evident that unless the borough system was reformed no great change in the character of the House of Commons could be expected, but the strength of the Government was concentrated in resisting Reform, because Reform would have been fatal to the Union (Froude's English in Ireland, III., p. II7). On all else the rule was to give way. A series of measures of

$$
\text { *Lecky, VI., p. } 597 .
$$


secondary reform was accordingly carried. "The pension list was to be gradually reduced to $£ 80,000$ a year, which was not hereafter to be exceeded, and no single pension amounting to more than $£_{1}, 200$ a year was to be granted except to Members of the Royal Family, or on an address of either House. It was computed that in this manner a saving amounting to $£ 30,000$ a year would be ultimately effected. The King, at the same time, surrendered his ancient power over the hereditary revenue, and a fixed Civil List, which was not to exceed $f_{1} 145,000$, exclusive of the Pension List, was granted to him. It was part of the arrangement that an Irish Board of Treasury was to be created, wholly responsible to the Irish Parliament, and this necessarily involved some considerable expense, especially as two Vice-Treasurers, being in England, had to be compensated for the loss of their offices, but it was hoped that the enormous expense of the collection of the Irish revenue would be materially reduced, and, by the abolition of the old hereditary revenue, the finances of the country were for the first time brought completely under the control of Parliament. This measure was very important as assimilating the Irish Constitution to that of England. In addition to this great measure, the Government accepted with little modification the Bill so frequently brought forward in the House of Commons for incapacitating most placemen and some pensioners from sitting in that House. No person who held any place of profit created after the passing of that Act, or who enjoyed a pension for years or during pleasure, might sit in the House of Commons. Several existing functionaries were excluded; members of Parliament who accepted places of profit already in existence were obliged to vacate their seats as in England, 
though they might be re-elected ; the number of commissioners for the execution of offices was limited, and every Member of Parliament, before taking his seat, was obliged to swear that he did not hold, either directly or indirectly, any pension or office which incapacitated him from sitting" (Lecky's History of England in the Eighteenth Century, VI., pp. 559-600).

This Statute, intended to guard the purity of Parliament against the corruption of Ministers, was, seven years later, used, under circumstances which will be described, to destroy the Irish Parliament. It will be observed that the Catholic Relief Act of 1793 was not followed, in accordance with constitutional practice when the electorate is appreciably enlarged, by a dissolution of Parliament, which ran on for four years longer. It is all but certain that Pitt, when he consented to the passing of measures of secondary reform, while he left the preponderance of nomination boroughs untouched, had already determined that the days of an independent legislature were numbered (Froude's English in Ireland, III., p. II 8 ). 


\section{THE FITZWILLIAM EPISODE.}

Among the measures of the Parliamentary Session of 1793, which, as we have seen, was remarkable for remedial legislation of great importance, must be recorded the passing of the Convention Act, declaring that assemblies of men calling themselves representatives under any pretence whatever to be henceforth illegal (33 Geo. III., c. 29). This measure, coupled with the rejection of all proposals for Parliamentary reform, which, if the Convention Act had nót been carried, would have rendered Parliamentary reform irresistible, indicates the determination of the reactionary clique of the upholders of ascendancy in Ireland, of whom FitzGibbon, the author of the Convention Act, was at once the ablest and the most unscrupulous, to accomplish the destruction of the Irish Parliament, which could not have been destroyed if it had been reformed. The Volunteer Convention in 1783 , for whose premature dissolution the caution of Lord Charlemont and the too sensitive constitutional instincts of Henry Grattan, with the reform scheme of Flood, which did not include the Catholics within its province, were responsible, had shown what an elected body, determined and in the confidence of an armed people, could do in terminating a system of Parliamentary corruption, and a Parliament, two-thirds of whose House of Commons were not the represen- 
tatives of the people, but the nominees of influential personages. If the Irish Parliament had been reformed the Union could not have been carried, and the Convention Act was aimed at the prevention of such reform with a view to the accomplishment of the Union. This measure, during the agitation for Catholic Emancipation, was a hindrance to O'Connell, who evaded its provisions with extraordinary ingenuity, at the risk of criminal prosecution therefor.* The Act for the disestablishment and disendowment of the Irish Protestant Church, whereby elections are allowed to Diocesan and General Synods, constitutes a repeal for such purposes of the Convention Act, which prevailed before the disestablishment of that Church to render such representative bodies illegal. When the Convention Act was repealed in 1878 ( $42 \& 43$ Vict., c. 28$)$, a curious section was inserted in the repealing Act showing the fear of an assembly of Irishmen elected by the Irish people for the discharge of quasi-parliamentary functions. It provides for the punishment of persons taking part in elections or proceedings of assemblies arrogating to themselves the functions of Parliament or aiming or tending to bring Parliament into hatred and contempt.

The contrast between the attitude of the Irish Parliament and the Irish people, which was so marked in the episode of the American War, was as pronounced in 1793, when the Irish Parliament supported Great Britain at the outbreak of the Great French War, Grattan pronouncing it to be the absolute duty of Ireland, when Great Britain is at war, to go to all lengths in befriending her, $\uparrow$ while without the walls of "The Borough Parliament," as the Irish Parliament was contemptuously called, there were many significant demonstrations in

* Fitzpatrick's Correspondence of Daniel O'Connell, I., p. 21.

†Lecky, VII., p. I. Ibid., pp. 22-23. 
favour of France. "An Alien Bill guarding against the danger of foreign emissaries, a severe Bill preventing the importation, removal, or possession of arms or ammunition without licence, an augmentation of the military establishment from 15,000 to 20,000 men, and a Bill directing the enrolment, for the space of four years, of a militia force of 16,000 men, raised, according to the English model, by conscription, passed rapidly and with little discussion" in the Session of 1793 (Lecky's Fistory of England in the Eighteenth Century, VI., p. 596). The new system of compulsory enlistment was fiercely resisted and resented. In three or four months, it is true, the military riots, the results of the Militia Act, were allayed by a measure encouraging voluntary enlistments and making some provisions for the families of those who were drawn by lot, but they contributed largely to the growing disaffection and to swell the ranks of the Defenders-an organisation which had its rise in factious hatred between the poorer Catholics and the poorer Presbyterians in the County of Armagh.* The Presbyterian Party were named "Peep of Day Boys" and the Catholic Party "Defenders," which implies that the Protestants were the aggressors. It was through the Defender movement, which was at first purely Catholic and local, with no political object, but for the protection of families from outrage or of homes from destruction, that the poorer ranks of Roman Catholics became absorbed in the United Irish Brotherhood, of which they eventually formed so potent a factor. $\dagger$ Towards the end of 1793 disturbances of all kinds in Ireland had greatly diminished, and the quiet continued in $1794 . t$

The Irish Parliamentary Session of 1794, which Mr.

*Lecky, VII., pp. If-I5. †Lecky, VII., pp. I8-I9.

$\ddagger$ Lecky, VII., pp. 2 I-22. 
Froude terms " a blank," commenced on January 2 ist and ended on March 28th.* Grattan enunciated his position most clearly in the discussion on the Address, and his authority in the House of Commons among the Members of the Patriot Party in the House was decisive. He said, to use the words of Mr. Douglas, the newly-appointed Chief Secretary, in his report to the British Cabinet, " that the errors of the Government in this Kingdom had been in a great degree corrected by laws of the last session ; that he deemed other measures of reform, and particularly a proper reform of Parliament, to be necessary, and he trusted the servants of the Crown would concur in them; that he did not, however, mean to propose such measures as matters of stipulation, but should give his unconditional support to the assistance of Great Britain, engaged in a war with our natural enemy, France, without questioning the merits or conduct of that war." $\dagger$ A motion subsequently moved by Grattan, asserting the necessity of establishing a definite and final commercial understanding between the two countries on the basis of perfect reciprocity, was most favourably received by the Government, who pleaded, however, for delay, and was at their request withdrawn. Ponsonby again introduced the same measure for Parliamentary reform he had proposed in the last Session, whose moderation hardened the United Irishmen in their conviction that the case of reform, if left in the hands of the Irish Parliament, was quite hopeless. The Government resisted the Bill, which was rejected by 142 votes to $44 . \pm$ Sir Lawrence Parsons, in his speech on this occasion, said: "A majority of this House never go back to their constituents ; they do not know them; they do not live amongst them; many of them never saw them-no, not even the places

* Froude, III., pp. $132-133$.

$\dagger$ Lecky, VII., pp. 2 I-23. $\quad$ Lecky, VII., pp. 25-26. 
they represent. What a mockery is this of representation! Do you think that in this enlightened age such an imposture can long continue ? Impossible." Grattan enunciated the position very concisely in these terms : "Before the Revolution, with the rights and the name, Ireland had not the possession of a Parliamentary Constitution, and since the Revolution she has no constitutional Parliament." *

From the prorogation of the Irish Parliament on the 25th March, 1794, till the opening of the next Session on the 22nd January, 1795-an interval of ten monthsthere were in foreign and British politics developments which profoundly affected Irish affairs. The alarming events of the French Revolution, the decree of fraternity issued by the French Convention, the execution of the King, the success of the revolutionary war, and the extravagance of the English democrats, had powerfully tended to alienate from the Whig Party some of its most enlightened and wisest leaders. In July, r794, the Duke of Portland, the Lord Lieutenant of the Rockingham Administration in 1782 ; Lord Fitzwilliam, a nobleman of large estates in Ireland and England, the intimate friend of Burke and Grattan, who both at different periods were Members of the British Parliament for the borough of Malton, of which he was the patron; Lord Spencer, who was to have succeeded the Marquis of Buckingham as Lord Lieutenant of Ireland if King George III. had not recovered from the mental aberration with which he had been afflicted in 1789, and $\mathrm{Mr}$. Windham, an eminent leader of the Whig Party in the House of Commons, became the adherents of Mr. Pitt, into whose Government they entered as holders of various offices. Lord Fitzwilliam was at first appointed

* Irish Debates, XIV., p. Ioz. 
President of the Council, while the Duke of Portland became Secretary of State for the Home Department, and, by virtue of his office, the Cabinet Minister responsible for the conduct of Irish affairs and the medium of communication between the British Cabinet and the Irish Lord Lieutenant. It was clearly understood that the Duke of Portland, whose liberal sentiments on the question of Catholic Emancipation and Irish Parliamentary Reform were well known, entered office under condition of having the general management and superintendence of Ireland, with the control of the Lord Lieutenant, under that Department. The retention in the Lord Lieutenancy of Lord Westmorland, who was, as we have seen, opposed to Catholic Emancipation and Reform, was to be of a temporary character, pending his appointment to another office, when the Viceroyalty would be filled by a nobleman in agreement and sympathy with the Duke's views, and ready and willing to carry out his Irish policy, and Earl Fitzwilliam, as early as August, 1794, consented eventually to accept the position of Lord Lieutenant of Ireland, for which he was to vacate Cabinet office. Catholic Emancipation was the pressing question of the hour. Pitt himself, Portland and Fitzwilliam were well known to be in favour of the measure. It was also no secret that the Irish Government could, through their power over the borough interests, procure the passage through the Irish Parliament of any Bill on which it had set its heart. Grattan went over to London in September, I794, to see the leading statesmen with reference to the contemplated changes in the Irish policy of the Government. Mr. Pitt sought a private interview with him in a letter reproduced by Grattan's son and biographer: “Mr. Pitt presents his compliments to Mr. Grattan. 
He wishes much, if it be not disagreeable to Mr. Grattan, to have an opportunity of conversing with him confidentially on the subject of an arrangement in Ireland, and for that purpose would take the liberty of requesting to see him either at 4 to-day or at any time to-morrow morning most convenient to Mr. Grattan." Mr. Grattan's son gives the following account of this interview " on the authority of his father, which there is no reason whatever for thinking inaccurately reported " :

"At the meeting between Mr. Grattan and Mr. Pitt, the latter was very plain and very civil in his manner. Mr. Grattan stated to him what his party desired, and mentioned the measures that he thought Ireland requiredthe essential one was the Catholic question. Mr. Pitt, upon this, remarked : ' Ireland has already got much.' Mr. Grattan did not tell him how she had got it (by her armed volunteers). They did not enter into the details of the question, but Mr. Grattan put it down upon paper, in reply to which $\mathrm{Mr}$. Pitt used these words : 'Not to bring it forward as a Government measure, but if Government were pressed, to yield it.' This unquestionably was a concession of the Catholic question, for Mr. Pitt knew well that the question would be pressed; it was certain to be brought on. All parties, Protestant, Presbyterian, and Catholic, had asked for it, and at their meetings had passed resolutions in its support. Nothing would keep it back: it was not an opposition question, nor cid it stand in need of any instigation, and of this Mr. Pitt was well aware. This was the arrangement that he made with Mr. Grattan, and, as the latter often mentioned, such were the identical expressions." (Grattan's Life, by his son, Henry Grattan, Esq., M.P., IV., p. 177.) 
In the middile of October, 1794 , a very serious difference arose between Pitt and his new colleagues from the Whig Party. The Duke of Portland and Lord Fitzwilliam had accepted the management of Irish affairs on the understanding that the Members of the Irish Administration should be in sympathy with them personally and politically. The claim that a Home Secretary and a Lord Lieutenant, who were the exponents of a definite policy with reference to Ireland, who had already formed close associations with leading statesmen in Ireland, should not have the selection of subordinate Members of the Irish Administration, with whom they could cordially co-operate, but should be cumbered by gentlemen with official positions in an Administration to whose policy they were admittedly opposed, would seem intolerable at the present day. Pitt, nevertheless, insisted that FitzGibbon, the Irish Chancellor, one of the greatest living opponents to the removal of Catholic disabilities, should be retained in office, and that no general change should be made in the personnel of the Irish Administration. Here again we see yet another poignant contrast between constitutional practice in England and in Ireland. "The system," wrote Grenville, " of introducing English party into Ireland, the principle of connecting changes of Government here with the removal of persons high in office there .... is so utterly irreconcilable with any view I may have of the state of that country, that I should be inexcusable if I could make myself a party to such a measure, and in this opinion Pitt entirely concurs " (Lecky's History of England in the Eighteenth Century, VII., p. 44). Lord Fitzwilliam accepted the Viceroyalty subject to the retention of Lord FitzGibbon in the Chancellorship, 
while he continued to act fairly in support of such a system as should be approved in England. The circumstances of Lord Fitzwilliam's appointment were the subject of discussion in the English House of Lords on the I9th March, I799, when his recall from the Lord Licutenancy was stated very plainly to have been a most powerful factor in the outburst of disturbance which came to a climax in the Rebellion of 1798 . In that debate Lord Fitzwilliam gives an account of the circumstances under which he assumed the Irish Viceroyalty, which exactly agrees with Mr. Pitt's statement to Mr. Grattan in October, 1794:

"I have understood that it has been stated in another place that during my administration in Ireland I was never required to retract what I had been directed by the Government to propose. If it had been stated I never received orders to bring forward the question of Catholic Emancipation on the part of the Government, I admit that statement to be true. But in justification of the part I took at the period, and as in my conscience I believe the events that occurred have led to the evils which now exist, and have stamped the doom of that ill-fated country, it is necessary to these statements I should add a short history of the transaction. Yielding to the argument of not wishing to entangle the Government in difficulties upon the subject at that period, I admit that, under orders clearly understood by me not to give rise to or bring forward the question of Catholic Emancipation on the part of the Government, I assumed the government of Ireland. But in yielding to this argument, I entered my protests against resisting the question if it should be brought from any other quarter, and I made most distinct declaration that in case of its 
being brought forward it should receive my full support. With these declarations, I assumed the government of Ireland. This I state upon my honour. I should not have introduced it had I not thought it necessary to give this explanation." Lord Fitzwilliam took the oath in the King's presence on December roth, 1794, Grattan being present at the ceremony. It was, as Mr. Froude well says, to be presumed, from the selection of a man whose opinions were so well known, that in some degree he was to be allowed to act on them (English in Ireland, III., p. I43).

Lord Fitzwilliam arrived in Dublin on January $4^{\text {th }}$. The Parliamentary session was to open on January 22 nd. Petitions from the Catholics poured in asking for emancipation, while there was not even one petition from Protestants against it. " I was no sooner landed," he afterwards wrote to the English Cabinet, " and informed of the real state of things here, than I found that this question would force itself on my immediate consideration." Fitzwilliam was most explicit and candid in his communications with the Cabinet. He acquainted them as to the minutest details of his public conduct and of the state of the country. The Cabinet, who had given Fitzwilliam discretion to support Emancipation if he believed it to be necessary, received in silence, week after week, his representations that Emancipation could not be deferred, and that he intended, unless he received directions to the contrary, to accept it. When Parliament met, although in accordance with the wishes of the English Cabinet nothing was said on the Catholic question in the speech from the Throne, the good feeling towards Lord Fitzwilliam's Government and policy was emphasised by Grattan in the moving of the address. 
Loyal addresses to the King and Lord Fitzwilliam were carried with enthusiasm. "Greater provisions for carrying on the war were made by Ireland than on any previous occasion in her history. The combined force of regulars and militia was raised to a little more than 40,000 men, and a vote of $£^{200}, 000$, moved by Grattan, for the British Navy, was speedily carried" (Lecky's History of England in the Eighteenth Century, VII., p. 63). "It was only on February 8th and 9th, when Parliament had been sitting for nearly three weeks, when the extraordinary supplies had been voted, when Catholic hopes were raised to the highest point, and when petitions for Emancipation were pouring in from every part of Ireland, that a discordant note was struck" (Lecky's History of England in the Eighteenth Century, VII., p. 7I). On the 8th February the Duke of Portland, as representing the British Cabinet, for the first time touched in his correspondence with the Lord Lieutenant on the Catholic question, of whose progress in Ireland the Lord Lieutenant had given him such full accounts, describing his own attitude in reference thereto, and laying stress on the supreme importance of the Emancipation movement. The Duke cautioned Fitzwilliam not to commit himself to "engagements," and even by encouraging "language" to giving his countenance to the immediate adoption of the measure. The deferring of it, he said, would be "the means of doing a greater service to the British Empire than it has been capable of receiving since the Revolution, or at least since the Union."* Lord Fitzwilliam's reply to this suggestion, coming from the nobleman who was, as we have seen, endeavouring to destroy the Irish constitution of 1782 , in the very first week of its existence, was highly dignified and humane. 
"I am at a loss," he wrote, " to conjecture what those benefits are which it is expected will accrue to the British Empire by deferring the consideration of this question. .. Can it be in the contemplation of any man that a state of disturbance or rebellion with her will tend to the desirable end (which I think I discover to be alluded to in your letter) of a union between the two kingdoms ? Doubtless, the end is most desirable, and perhaps the safety of the two kingdoms may finally depend on its attainment ; but are the means risked such as are justifiable or such as any man would wish to risk in hope of attaining the end ? Through such a medium I look for a union, I am ready to grant, but it is not the union of Ireland with Great Britain, but with France. . . . But, supposing the object may be thought attainable in the end by such means, still, it must be allowed to be at a distance, and must be admitted not to be a moral certainty. Who will then advise to be hunting after a distant and contingent good at the evident and admitted price of a certain and immediate evil ?"* In this letter we see a clear indication of the horrible suspicion passing in the mind of the Lord Lieutenant of the scheme of promising Catholic Emancipation, of breaking that promise, of irritating the people into a rebellion which would be suppressed by bloodshed, and of utilising the terror produced by that rebellion, in conjunction with bribes of peerages, offices, pensions, and gross metallic corruption, for the passing of the Union.

The Catholic Relief Bill was introduced by Mr. Grattan in the House of Commons on 12th February, 1795. Duigenan and Ogle were its sole opponents. "One fact," writes Mr. Lecky, " is as certain as anything in Irish history-that if the Catholic question was not

*Lecky, VII., pp. 75-76. 
settled in 1795 , rather than in 1829 , it is the English Government, and the English Government alone, that was responsible for the delay " (Lecky's History of England in the Eighteenth Century, VII., p. 70). On February 14th Lord Fitzwilliam wrote to the Duke of Poitland positively refusing to attempt any postponement of the Catholic Bill. "All I have to add," he says, " is that I will not be the person so to put it off on the part of the Government. I will not be the person who I verily believe by so doing would raise a flame in the country that nothing short of arms would be able to keep down" (Lecky's History of England in the Eighteenth Century, VII., pp. 72-73). In the plainest and most direct terms Fitzwilliam was, on the I8th February, ordered by the Duke of Portland, on behalf of the Cabinet, to take the most effectual means in his power to prevent any further proceedings being taken on the Bill before the House till the King's pleasure was signified. The next day the Cabinet agreed to recall him, and on the 23rd February he was directed to appoint Lords Justices to conduct the Government till the arrival of his successor. Mr. Lecky, speaking of this transaction, says that the correspondence between the Lord Lieutenant and the English Cabinet discloses on the part of the English Ministers a neglect of duty which is simply astounding.* $\mathrm{Mr}$. Froude comes to a similar conclusion, which is strengthened by the fact that till the $5^{\text {th }}$ February, when the Cabinet had been themselves for three weeks at least aware of what Fitzwilliam was doing, the King, who was to their knowledge bitterly opposed to Catholic Emancipation, had been kept in ignorance that any immediate step in favour of Catholics was in contemplation. He thinks it impossible " to acquit the Cabinct in 
allowing Fitzwilliam to commit himself so deeply if they were themselves still undecided; still less can they be acquitted for having kept in complete ignorance of the contents of Fitzwilliam's despatches a person (the King) whose consent was indispensable to any intended change" (Froude, III., p. I48). "If," said Sir Lawrence Parsons in the House of Commons on March 2nd, " the Irish Administration has encouraged Catholics in their expectations without the countenance of the British Cabinet, they have much to answer for. If the British Cabinet had assented and afterwards retracted, the demon of darkness could not have done more mischief had he come from hell to throw a fire-brand among the people. Let the Ministry persevere, and the Army must be increased to myriads, and five or six dragoons must be quartered in every house in the kingdom " (Froude's English in Ireland, III., pp. I 56-157).

The dismissal of Lord Fitzwilliam was ascribed at the time by Lord Fitzwilliam himself, by Grattan, by Edmund Burke, and by the Ponsonbys, not so much to a volte face by the Cabinet on the Catholic question as to Lord Fitzwilliam's determination that his work in Dublin should not be paralysed by Castle officials, the creatures of influence who were bitterly opposed to his policy, and determined, as far as in them lay, to render it futile. Lord Fitzwilliam had, on his arrival in Dublin, relieved John Beresford of his office as Commissioner of the Revenue, but had provided th.t his salary should be paid to him in full. He contemplated making arrangements for the removal of the Law Officers of the Crown, with compensation satisfactory to themselves. He had, moreover, removed two Castle officials, Cooke and Sackville Hamilton, who were notoriously opposed to 
the concession of Catholic claims. These gentlemen placed themselves in communication with Mr. Pitt, the late Viceroy Lord Westmorland, and Lord Auckland, who, as Mr. Eden, had been Chief Secretary for Ireland, and was on terms of intimacy with Beresford, who was closely connected with Lord FitzGibbon.. Mr. Pitt, in a letter of February $2 x$ st, censuring Lord Fitzwilliam, stated, it is true, that he concurred in the general desire of the Cabinet that Grattan's Bill should not be allowed to make further progress, but he places the dismissal of Fitzwilliam mainly on the ground of his conduct to former supporters of the Cabinet. When we bear in mind the letter of Portland to Fitzwilliam, stating that he would render an incalculable service to the Empire in delaying the question of Catholic Emancipation; Pitt's own confessions in his correspondence of a desire for the Union; his knowledge that Catholic Emancipation and the reform of Parliament, which would be its necessary sequel, would render the accomplishment of the Union difficult, if not impossible; the certainty that, under the conditions then obtaining in Ireland, the disappointment of the popular hope in respect of Catholic Emancipation and Parliamentary reform would render an insurrection inevitable, it is all but certain that the dismissal of Fitzwilliam was not due to the family influence of jobbish Castle cliques, but to a deep-laid plan of paving the way for the Union by promoting an insurrection which could be crushed, but which could be used as a factor for the destruction of an Irish Parliament, which was all the more assailable because unreformed.

"It is probable," writes Mr. Lecky, "that Mr. Pitt was already looking forward to the Union. The steady object of his later policy was to corrupt and to degrade 
in order that he ultimately might destroy the legislature of the country. Had Parliament been made a mirror of the national will, had the Catholics been brought within the pale of the Constitution, his policy would have been defeated " (Leaders of Public Opinion in Ireland, p. I46).

Mr. Froude, who, in trend of thought, was very divergent from Mr. Lecky, comes to the same conclusion. "Pitt," he writes, "was thinking of a Union, and could he have seen that the Union could be secured, the venture (of Catholic Emancipation), though a hazardous one, might still have been risked without extreme imprudence; but the companion measure of Emancipation would be almost necessarily Reform, and Pitt's ignorance of the country must have been extraordinary, even in an English Prime Minister, if he could dream that Catholic Ireland, in constitutional possession of the powers which the majority of members would confer on the Catholic party, would then be persuaded to part with her independence" (English in Ireland, III., pp. I4I-I42). It is not, perhaps, unworthy of observation that in 1795 , as in 1800 , at the time of the Union, the King was kept in ignorance of negotiations between leading Catholics and the Ministers in reference to Catholic Emancipation, to which, on both occasions, when the matter was brought before him, he gave, as his Ministers knew well when duping the Catholics he would do, a decisive opposition. Four years later, in the British House of Commons, in a Union debate, Mr. Sheridan, without fear of contradiction, thus explained the true inwardness of Lord Fitzwilliam's appointment to the Irish Lord Lieutenancy as a pronounced protagonist in the cause of Catholic Emancipation, and of his recall. 
Sneaking on February I Ith, I799, Mr. Sheridan said : " The natural inference was that when Mr. Pitt appeared to countenance the scheme of Emancipation, he never entertained any idea of carrying it into execution, and that he sent over Lori Fitzwilliam merely to dupe the Irish Catholics for a time to suit his own purposes. The primary object of Lord Fitzwilliam's administration was, from the first moment of his landing in Ireland, avowed to be the complete emancipation of the Catholics. It was known by every member of the Irish Parliament, and to every man in the country it was equally well known, that it constituted the avowed ground of Lord Fitzwilliam's recall, and yet, so far was it from exciting their displeasure, there never was a Lord Lieutenant who left Ireland accompanied with testimonies of more general regret for his departure than Lord Fitzwilliam. Again, Mr. Pitt had argued that it was unsafe to grant Catholic Emancipation without Union. He (Mr. Sheridan) would then ask why he had authorised Lord Fitzwilliam to promise it, why he had raised the expectation in the minds of the Catholics, of the fallacy of which he had since endeavoured to convince them by a system of cruel massacre and torture of every denomination. He repeated it that he considered the right honourable gentleman, and those who supported him with a mercenary confidence, as the authors of all calamities which had befallen that unhappy country." " Mr. Pitt," writes Grattan's biographer, clearly indicating the conclusion at which Grattan himself, with special means of information, had arrived, " abandoned his principles, his promises, and his professions. He first deceived, and then recalled, Lord Fitzwilliam, and committed the basest breach of public faith that had occurred since the 
days of Lord Strafford (in the matter of the Graces), and not very dissimilar from it. By so doing he gave the country over to the United Irishmen, and prepared the way for the insurrection and the Union. His measures were fatal for British character, and the Irish people henceforth lost all confidence in the British Government" (Grattan's Life, IV., p. 195).

Mr. Lecky, who has modified his earlier judgments on some Irish questions, held all through life his first view of the Fitzwilliam episode, whose disastrous effects on the whole course of subsequent Irish history the researches of later years still more forcibly impressed upon him. Writing in I86I, Mr. Lecky says : "It is certain that the recall of Lord Fitzwilliam arrested a policy which would have made the Union at that time impossible. By raising the hopes of the Catholics almost to a certainty, and then dashing them to the ground, by taking this step at the very moment when the inflammatory spirit engendered by the Revolution had begun to spread among the people, Pitt sowed in Ireland the seeds of discord and bloodshed, of religious animosities and social disorganisation, which paralysed the energies of the country and rendered possible the success of his machinations. The rebellion of 1798 , with all the accumulated miseries it entailed, was the direct and predicted consequence of his policy" (Leaders of Public Opinion in Ireland, pp. 146-I47). Writing thirty years afterwards, in 1890 , Mr. Lecky feels strengthened in this view. "The recall of Lord Fitzwilliam," he says, " may be justly regarded as a fatal turning point in Irish history. For at least fifteen years before it occurred the country, in spite of many abuses and disturbances, had been steadily and incontestably improving. Religious 
animosities appeared to have almost died away. Material prosperity was advancing with an almost unprecedented rapidity. The Constitution, in many important points, had been ameliorated, and the lines of religious disability were fast disappearing from the Statute Book. The contagion of the French Revolution had produced a dangerous organization in the North and a vague restlessness through the other Provinces, but up to this time it does not appear seriously to have affected the great body of Catholics, and Burke was probably warranted when, in estimating the advantages which England possessed in her struggle with France, he gave a prominent place to the loyalty, the power, and the opulence of Ireland. With the removal of the few remaining disabilities, a settlement of tithes, and a moderately reformed Parliament, it seems still probable that Ireland-under the guidance of her resident gentry-might have contributed at least as much as Scotland to the prosperity of the Empire. But from the day when Pitt recalled Lord Fitzwilliam the course of her history was changed. Intense and growing hatred of England revived, religious and class animosity, a savage rebellion, savagely repressed, a legislative union prematurely and corruptly carried, marked the closing years of the Eighteenth Century, and, after ninety years of direct British Government, the condition of Ireland is universally recognised as the chief scandal and the chief weakness of the Empire" (Lecky's History of England in the Eighteenth Century, VII., p. 98).

O'Connell has explained the whole Fitzwilliam episode on the hypothesis that the English Government deliberately promoted the rebellion for the purpose of carrying the Union. He dwelt on the fact that the 
Government, before the outbreak of the rebellion, had secret information furnished by a traitor named Maguan to the Reverend Dr. Clelland, Lord Londonderry's land agent, pointing out its most active leaders, and that, in spite of the suspension of the Habeas Corpus Act, these leaders were suffered to remain at large. "The Irish House of Commons," said O'Connell, " in 1798 had a Secret Committee to enquire into the facts and circumstances connected with the rebellion. The Report of that Committee was published, and I take my authority from it. I say the Irish Government cherished and fomented treason at that dreadful period, and allowed the traitors to go at large with impunity at that dreadful time in order that the treason might ripen into an extinguishable rebellion" (Debate in the Dublin Corporation on Repeal of the Union, 1844, p. 38). Mr. Gordon, a Protestant clergyman in the County of Wexford, the historian of the rebellion, some of whose horrors he witnessed, and himself in favour of a Union, admits that the Union could not have been carried if there had not been an insurrectionary outbreak. "So odious," he writes, "was the measure to multitudes whose pride or private interests, real or imaginary, were engaged, that it could not, with the smallest probability of success, be proposed until prejudice was in some degree overcome by the calamities and dangers of the rebellion" (Gordon's History of the Irish Rebellion, pp. 295-296).

Miss Edgeworth, whose father was a distinguished Member of the Irish House of Commons, has a similar view of the calculated effect of the rebellion upon the Union. "Government," she writes, "having at this time the Union between Great Britain and Ireland in contem- 
plation, was desirous that the Irish aristocracy and country gentlemen should be convinced of the kingdom's insufficiency to her own defence against invasion or internal insurrection. With this view it was politic to let the different parties struggle with each other till they completely felt their weakness and their danger. . . . . It is certain that the combination of the disaffected at home and the advance of foreign invaders were not checked till the peril became imminent, and till the purpose of creating universal alarm had been fully effected " (Life of R. L. Edgezvorth, II., pp. 217-218).

Mr. Lecky thus deals with the charge, of which the Fitzwilliam episode, even if taken alone, supplies cogent evidence, that the English Government, desiring a Union, and perceiving it could not be effected without a convulsion, deliberately forced on the rebellion as a means of effecting it: "Fluctuating and unskilful policy has often the effects of calculating malevolence, and mistakes of the Government, both in England and Ireland, contributed undoubtedly very largely to the hideous scenes of social and political anarchy, to the religious hatreds and religious panics which alone rendered possible the legislative Union. Nor can it, I think, be denied that it is in a high degree probable that a desire to carry a legislative Union had a considerable effect in dictating the policy which, in fact, produced the rebellion, and that there were politicians who were prepared to pursue that policy even at the risk of a rebellion, and who were eager to make use of the rebellion when it broke out for the purpose of accomplishing their designs. The following striking passage from a work which I have often quoted shows the extreme severity with which the situation was judged by a perfectly loyal writer who 
was in general one of the most temperate and most competent then living in Ireland : 'To affirm.' writes Newenham; 'that the Government facilitated the growth of the rebellion for the purpose of effecting the Union would be to hold language not sufficiently warranted by the facts. But to affirm that the rebellion was kept alive for that purpose seems perfectly warrantable. The charge was boldly made in the writer's hearing during one of the debates on the Union by an honourable gentleman who held a profitable place under the Crown. And to affirm that that measure never would have been carried into effect without the occurrence of a rebellion similar in respect of its attendant and previous circumstances to that of 1798 , is to advance what nineteen or twenty men who were acquainted with the political sentiments of the Irish people at that time will feel little difficulty in assenting to.' " (Newenham's State of Ireland, pp. 269-270. Lecky's History of England in the Eighteenth Century, VIII., pp. 285-286.) 
OPPOSITION TO IRISH PARLIAMENTARY REFORM. $27 \mathrm{I}$

XXI.

THE OPPOSITION OF THE BRITISH GOVERNMENT TO IRISH PARLIAMENTARY REFORM AND CATHOLIC EMANCIPATION.

The successful resistance to Parliamentary Reform in 1783 , followed by the indefinite adjournment of the Volunteer Convention, sealed the fate of the Irish Parliament, for that Parliament, if reformed and truly representative of the people, could never have been destroyed. The withdrawal of the Commercial Propositions in 1785 , and the substitution therefor, after a great increase of taxation had been voted on the faith of these propositions becoming law, of a series of proposals which could not be accepted by the Irish Parliament consistently with the preservation of its independence, and ten years later the recall of Lord Fitzwilliam from the Lord Lieutenancy after his announcement of a full measure of Catholic Emancipation as the cardinal policy of the Government, and yet another large increase of taxation had been voted on the faith of that announcement, produced that absolute distrust in the promises of English statesmen which precluded all hope of the wants and wishes of the people being satisfied under the established régime, and that feeling of intense contempt for constitutional methods 
which caused the rebellion on which the Government had relied as a means of paving the way for the Union. Lord Fitzwilliam was himself under no delusion with respect to the effect of his recall. He wrote to Lord Carlisle that the English Ministers must face "almost the certainty of driving this Kingdom (of Ireland) into rebellion." * Sir Lawrence Parsons moved a short Supply Bill in the House of Commons, which was, of course, negatived by an assembly to whose composition I have so often adverted, and, at the instance of Grattan, a resolution by $\mathrm{Mr}$. Connolly, protesting against the prorogation of Parliament before the grievance complained of was removed, was withdrawn. $\dagger$ Lord Fitzwilliam, at the entreaty of his friends, postponed his departure for a fortnight, dreading that, if the Government were left in the hands of Lords Justices before the arrival of his successor, there would be a popular outburst. He only consented to the adjournment of Parliament on the strong representation that such a measure was absolutely necessary to the preservation of the public peace. $\downarrow$ Great meetings of the Catholics, summoned by the Catholic Committee, and meetings of Protestant freeholders petitioned for the retention of Fitzwilliam in office, and in favour of the complete removal of Catholic disabilities. Delegates were sent to London to lay the petition on behalf of the Catholics before the King, and on their return to Dublin, after an unsuccessful mission, the Catholic Committee convened another great meeting, at which the following resolutions were unanimously passed, which showed that the true inwardness of Fitzwilliam's recall was a desire to promote a Legislative Union between Great Britain and Ireland :- " That we are sincerely and unalterably attached to the rights, * Lecky, VII., p. 90. †Lecky, VII., p. 93. † Iecky, VII., p. 96. 
liberties, and independence of our native country; that we pledige ourselves, collectively and individually, to resist even our own emancipation, if proposed to be conceded on the ignominious terms of an acquiescence in the fatal measure of a Union with the sister kingdom; that, while we make this undisguised declaration of our sentiments in order to satisfy the public mind, we are of opinion that a measure so full of violence will never be hazarded, convinced as we are that no set of men will arrogate to themselves a power which is contrary to the ends and purposes of all government, a power to surrender the liberties of their country and to seal the slavery of future generations." (See Lecky's History of England in the Eighteenth Century, VII., pp. 94-95).

The attitude of the great mass of the Catholic population on the question of the Union was that of uncompromisirg resistance. The resolution of the great meeting convened by the Catholic Committee to oppose to the utmost a Union, even if accompanied with Catholic Emancipation, embodied to the very last the policy of all that was best and highest in Irish Catholic public life. Mr. Froude, whose hatred of Catholicism and admiration for the Union are among the most indubitable characteristics of his writings, admits, while he endeavours to disparage, the hatred of the Catholics to the Union. "At one time," he writes, "Lord Cornwallis (the Lord Lieutenant of the Union) hoped to overcome and weaken the opposition (to the Union) by the help of the Catholics, but the Catholics would not listen to his blandishments. They trusted, if the separate Parliament were maintained, to make their way into it eventually, and though England had saved them from extermination by their Protestant countrymen, yet as long as there was a 
hope of success they preferred to join the Protestant opposition in defence of their natural independence" (English in Ireland, III., pp. 549-550).

The testimony of Mr. O'Connell, who had grown to man's estate and had been called to the Bar while the Irish Parliament was in existence, is, on this matter, I think, conclusive. Speaking in the discussion on the Repeal of the Union in the Dublin Corporation in 1843 , Mr. O'Connell said : " The first time I ever addressed a public assemblage, when I shuddered at the echo of my own voice, was on the 13 th January, 1800 . That was my ' maiden speech,' and it was made against the Union. I wish to show what my sentiments then were by reading a paragraph from my published speech. I can bear testimony to the accuracy of the report, because I wrote it myself. The original is in the hands of a member of my family. This is what I said: 'There was another reason why they (the Catholics) should come forward as a distinct class-a reason which he confessed made the greatest impression upon his feelings. Not content with falsely asserting that the Catholics favoured the extinction of Ireland, that their supposed inclination was attributed to the foulest motives, motives which were repugnant to their judgments and most abhorrent to their hearts, it was said that the Catholics were ready to sell their country for a price, or, what was still more depraved, to abandon it on account of the unfortunate animosity which the wretched temper of the times had produced. Can they remain silent under so horrible a calumny ? This calumny was flung on the whole body -it was incumbent on the whole body to come forward and contradict it. Yes, they will show every friend of Ireland that the Catholics are incapable of selling their 
country ; they will loudly declare that if their emancipation was offered for their consent to the measure-even if emancipation after the Union were a benefitthey would reject it with prompt indignation.' (This sentiment met with loud approbation.) 'Let us,' said he, "show to Ireland that we have nothing in view but her good; nothing in our hearts but desire of mutual forgiveness, mutual toleration, and mutual affection; in fine, let every man who feels with me proclaim that if the alternative were offered to him of Union or the reenactment of the Penal Code, with all its pristine horrors, that he would prefer, without hesitation, the latter as the lesser and more sufferable evil; that he would rather confide to the justice of his brethren, the Protestants of Ireland, who have already liberated him, than lay his country at the feet of foreigners.' (This sentiment met with much and marked approbation.) I added: 'If there was any man present who could be so far mentally degraded as to consent to the extinction of the liberty, the constitution, and even the name of Ireland, he would call on him not to leave the direction and management of her commerce and property to strangers over whom he has no control.' That," said Mr. O'Connell, "was my first speech, and the tenor of my public life shows that I have never varied from the sentiments it contained."

Fitzwilliam left Iteland on March 25th, 1795, amid demonstrations of affection and regret which have seldom, if ever, been produced by the departure of an Irish Lord Lieutenant. Lord Camden, his successor, whose Secretary, Mr. Pelham-who had filled that office in Lord Temple's administration in 1783 -was already in Ireland, arrived in Dublin on March 31st, 1795. His 
entry was signalised by a fierce riot, in which two lives were lost, and the houses of FitzGibbon, Beresford, and Foster, the Speaker-to whose influence the change in the personnel of the Viceroy was attributed-were attacked. The Lord Lieutenant's instructions to set Catholic against Protestant and Protestant against Catholic were plain in their wicked cynicism. The Duke of Portland, on behalf of the Cabinet, tells him that he must do his best to rally the Protestant interests against concessions to Roman Catholics. He must hold a firm and decided language of hostility to them, but he must also tell the Protestants that, without their concurrence, the Government cannot effectually resist ; that, with their concurrence, the Government will be ready to make every exertion they can desire to prevent the admission of Catholics to seats in the legislature. While the Duke of Portland was instructing the Lord Lieutenant to revive religious animosities, which had all but disappeared in Ireland, he was equally emphatic in urging him to discountenance the idea of Ministerial responsibility to the Irish Parliament. "A notion," he writes, " has arisen within these few years, and has latterly but too generally prevailed, of the propriety of the existence of an Irish Cabinet. I, therefore, think it necessary to protest and caution your Lordship against it in the strongest and most explicit terms, for to me it appears unconstitutional in the highest degree, and directly subversive of English Government and of the unity of the British Empire. It would annihilate the responsibility of the Lord Lieutenant to the English Government, and would more immediately tend to the separation of the two countries and the introduction of anarchy into Ireland than any other means that could be devised" (Lecky's 
History of England in the Eighteenth Century, VII., Pp. IOI-103).

Parliament met on April 1 3 th, 1795, the day to which it had been adjourned. On April 2 ist, Grattan moved for a Committee on the State of the Nation, in which the whole question of the recall of Lord Fitzwilliam was discussed. Grattan, who was confirmed in his statements by the Ponsonbys, detailed the terms under which he and the gentlemen who acted with him had agreed to support the Fitzwilliam administration. The Government did not attempt to traverse the account of the transaction, either generally or in its details, as told by Grattan, which have been summarised in these pages. They simply relied on the royal prerogative as conferring an undoubted right to recall a Viceroy. The motion, after a speech in reply from Grattan, was negatived by ${ }_{15} 8$ to 48 .

On May $4^{\text {th }}$ the second reading of the Catholic Bill came on ; the debate lasted till ten the following morning, when the majority in the House of Commons who, a few months before, had been perfectly ready to carry the Bill, were now equally ready to reject it, and it was thrown out by 155 votes to 89 . This incident shows, in the vords of Mr. Lecky, with a painful vividness, the character of the Irish House of Commons-" a body which contained a group of statesmen who, in ability, patriotism, and knowledge, would have done honour to any legislature, but also a body on which eloquence and argument dashed uselessly and impotently against a great purchased majority." (See Lecky's History of England in the Eighteenth Century, VII., p. I08.)

It was repeatedly asserted throughout this debate, and not even indirectly denied, that the Irish Parliament, 
if left to itself, and uninfluenced by the English Administration, would have granted Catholic Emancipation, and that the boon was refused by the English Government with a view to a Union. "In I792," said Parsons, "a majority decided against giving any further privileges to the Catholics. In 1793 the same majority passed the Catholic Bill. At the beginning of the Session everyone believed that a majority would have voted for this Bill. Everyone believes that a majority will vote against it now, and should the English Ministers in the next Session wish it to pass, who does not believe that a majority will vote for it ? Besides, if the English Ministry should be changed - an event perhaps not very remotethis Bill would be immediately adopted."

"The Protestants," said Grattan, " of a number of counties, of all the great cities, and all the mercantile interests have petitioned in favour of the Catholics. With the single exception of the Corporation of Dublin, there has been no application against them. Nothing prevents their success but the influence of the Government. Catholic Emancipation ceases to be a question between the Irish Protestants and Catholics, and is now a question between the Ministers of another country and the people of Ireland." The opposition to the measure with a view to the Union was openly denounced. "Take your choice," said Mr. Knox, one of the members for Dublin University-" re-enact your penal laws, risk 2 rebellion or separation or a Union, or pass this Bill, for the hour is nearly arrived when we must decide. The hour is already come when we ought to decide."

"You," said Mr. Arthur O'Connor, subsequently a United Irish Leader-" you who shall on this night vote for the rejection of the Bill will appear in the eyes of the 
Irish Nation not only as men voting in obedience to the British Minister against the voice of the people, but as men voting for a Union with England by which this country is to be everlastingly reduced to the state of an abject province." "The Roman Catholic," said Mr. Grattan, in reference to the resolution passed at the Dublin meeting, "far from being ungenerous, has borne his testimony in favour of the institution of the Irish Parliament, for he has resolved to relinquish his emancipation rather than purchase his capacities by a Union. He has said, 'Let the Catholic be free, but if his freedom is to be bought by the extinction of the Irish Parliament, we waive the privilege and pray for the Parliament.'" (See Lecky's History of England in the Eighteenth Century, VII., pp. Io8-I I 5.)

Lord Camden, who was not deficient in obeying his instructions to rally the Protestant interest, emphasised the rejection of the Catholic Emancipation Bill by recommending, in a letter which was written to the Duke of Portland on the very day that Bill was under discussion, the conferring of an Earldom on FitzGibbon, the most envenomed enemy of Catholic rights in his generation, and one of the principal machinators of the recall of Lord Fitzwilliam and the defeat of his policy, who was even at that time intriguing for the destruction of the Irish Parliament.*

A very great measure, however, characterised the Session of the Irish Parliament, which Chief Justice Whiteside happily describes as "a Session short, but exciting." In Lord Fitzwilliam's speech from the Throne, at the opening of the Session, new measures for Catholic education were promised, and with this object an ecclesiastical seminary was founded at Maynooth.

$$
\text { *Lecky, VII., p. I } 6 .
$$


“A Catholic college," writes Mr.Lecky, “on a small scale had been established at Carlow in I793. It was intended, however, for the education of laymen, and the College of Maynooth was the first Irish establishment since the Revolution for the education of the priesthood. Though instituted primarily for the education of that body, there was at first some question of including Catholic lay students in the establishment, and, although this project was dropped, no further restriction was introduced into the Bill than that the College was to be for the better education of persons professing the Popish or Roman Catholic religion. Its government was placed in the hands of a body of trustees, to which the Chancellor and the three other Chief Judges officially belonged, but which consisted mainly of the Catholic Bishops, who, however, were elected as individuals and not as enjoying any titular rank or dignity. They were empowered to purchase lands to the annual value of $f_{1}, 000$, and to receive private subscriptions and donations without limit for the purposes of the College. There was at first no Government endowment for the education of the students, but an immediate Parliamentary grant of $£ 8,000$ was voted to purchase a house and other necessary buildings for their accommodation. Dr. Hussey was appointed President." (See Lecky's History of England in the Eighteenth Century, VII., pp. 126-127.) The establishment by an Irish Protestant Parliament of a seminary for the education of Roman Catholic priests cannot be regarded as other than an irrefragable proof that that Parliament, if free from borough members, would have completely emancipated the Roman Catholics of Ireland, which it was prepared to do if the English Government, who was the paymaster of the bribed 
members, had consented, or rather had not withdrawn a consent which had been given. There can be little doubt that the main object of founding the College at Maynooth was to preserve the Irish priesthood, who were educated abroad, from imbibing the doctrines of the French Revolution. Wolfe Tone welcomed the project on far different grounds, which shows he was superior in foresight to the English Cabinet and its advisers. "This country," he writes, " never will be well until the Catholics are educated at home and their clergy elective. Now is a good time, because France will not receive their students, and the Catholics are afraid of the Revolution." *

$$
\text { *Lecky, VII., p. I } 2 \text { I. }
$$


XXII.

\section{AN UNREFORMED AND CORRUPT PARLIA- MENT AND COERCIVE LEGISLATION.}

THE scope of this work is not to deal with the general history of Ireland, but rather to sketch the history of the Parliament of Ireland, which was, of course, in the nature of things, profoundly affected by external influences, on which I have merely touched in their relation to the proceedings of Parliament, and to the attitude of Parliament in respect of public movements out of doors. In a sketch of the period between the recall of Lord Fitzwilliam and the Union, I only aim at attempting to describe the closing days of the Irish Parliament, as it was affected by religious and political animosities purposely fomented by the English Government. The persecution of Catholics by the Peep of Day Boys, which took its origin in Armagh, and spread throughout a large part of the Kingdom, and was opposed by the Defenders, a Catholic organisation for the protection of the lives and liberties of members of the Catholic Faith against their Protestant assailants; the Battle of the Diamond, in Armagh, in September, 1795, which was the origin of the Orange Society as we know it; the struggle of the United Irishmen for the establishment of Irish independence, when all hopes of Parliamentary reform were at an end; the gradual union of the United Irish with the Defenders in a great national association, 
irrespective of creed and party, for the regeneration of Ireland ; the promise of assistance from France, and the hopes and fears, and trend of thought produced by the imminence of French invasion, which were not ended by the Bantry Bay Expedition; the free quarters, the search for arms, the filling of the country with troops, the military excesses; the murders in cold blood by the yeomanry, who were Protestants and Orangemen to a man, numbering upwards of $50,000 \mathrm{men}$, in the Insurrection ; burnings, rapes, murders; the seizure by magistrates of persons suspected of being disloyal, without trial, without sentence, without even a colour of legality, and sending them to serve in the King's Fleet; the floggings, half hangings, pitch-cap torture-all these methods ostensibly for the restoration of order, in reality for terrorising the Irish Parliament into the passing of the Union, must be left unrecorded by me, and can only be referred to as their effects are seen in the proceedings and legislation of the doomed Irish Parliament, which was not permitted to reform itself, but was only allowed to assist and legalise the system of military terrorism which alone rendered its destruction practicable.

The short Session of Parliament, which began on January 2rst and ended on April I 5th, I796, was mainly occupied by an Act of Indemnity for such persons as had in the preceding half-year exceeded their legal powers, and by an Insurrection Act. An amendment to the Address to the Throne was moved by Grattan, demanding free trade between Great Britain and Ireland on the basis of equalisation of duties. He was defeated in the division by 122 to 14 , and in another division by 82 to 16 .

The Insurrection Act, with which the Indemnity Act was accompanied, can, having regard to its pro- 
visions, be only regarded as an incitement on the part of the Government to an armed resistance which would in its turn be savagely defeated, while the terror thereby produced could be utilised for the destruction of the Parliament. "This Act (36 Geo. III., c. 20) made it death to administer, and transportation for life voluntarily to take, a seditious oath. It compelled the production of arms for registration, and enabled the Lord Lieutenant and Council, upon a memorial from the magistrates, to proclaim particular districts as in a state of disturbance. In proclaimed districts the inhabitants were forbidden to be out of their houses from an hour after sunset till sunrise, and justices of the peace were empowered to search all houses during the prohibited hours to ascertain whether the inmates were abroad or whether arms were concealed. They might also demand the surrender even of registered arms, and there were stringent clauses against ' tumultuous assemblies by day time,' against meetings by night in public houses, against men and women who sold seditious and unstamped papers" (Lecky's History of England in the Eighteenth Century, VII., p. 197). A clause, very strenuously opposed by Grattan and Sir Lawrence Parsons, actually legalised one of the worst excesses of legal powers in the preservation of the public peace, whose previous perpetration had been condoned under the Indemnity Act. By this clause magistrates in the proclaimed districts were enabled to send men, whom they considered disorderly characters, untried to the fleet. "Under this comprehensive category," writes Mr. Lecky, "were comprised all who were out of doors in the prohibited hours, and who could not give a satisfactory account of their purpose, all who had taken unlawful oaths, all who 
could not prove that they had lawful means of livelihood" (Lecky's History of England in the Eighteenth Century, VII., p. 197). The conduct of the Government in directing their measures solely against the class of crime by which the Defender movement was at times accompanied, and preserving a complete silence in reference to the outrages of Orangeism, whereby families had in terror been compelled to abandon their homes, was the subject of Grattan's bitter comment.

This atrocious enactment, whose savage administration was a main factor in the production of the Insurrection which produced the Union, was regarded in England as a regrettable necessity. The facility of its passage through the Irish Parliament was held to be its justification by the Duke of Portland, who, as a former Lord Lieutenant, was well acquainted with the constitution and composition of that Parliament, and the methods by which it was made amenable to English influences, who was, at the very time, planning its destruction, and who had ridiculed its pretensions to a control of the Irish Government. "Of your Insurrection Act," writes the Duke of Portland to Lord Camden, "I will only say that, though the necessity of such a measure is but too well established by the facility of its passage through Parliament, my astonishment at the existence of such a necessity in a country enjoying the same form of government as this is not abated by the event."* The Session ended on April 15th, 1796. Parliament sat again for a few weeks in October and November, I 796. The principal measure was a suspension of the Habeas Corpus Act, which was carried with rapidity, there being only seven dissentients, among whom, however, was Grattan. A resolution, moved by Grattan, in favour of Catholic Emancipation, was

*Lecky, VII., p. 199. 
defeated by 143 to 19 . This was the last occasion on which the question of Catholic Emancipation was raised in the Parliament of Ireland. An Act making conspiracy to murcer a felony of the same nature as murder itself, substituting the punishment of hanging for that of burning in the execution of women, preventing the importation and regulating the sale of arms, and raising the salaries of the judges, were the principal legislative measures of 1796.* Mr. Lecky thus sums up the political situation in Ireland at the end of the Wolfe Tone Expedition: "Anarchy and organised crime had greatly extended, and they were taking a more political form, while Grattan and other really able, honest, moderate, and constitutional reformers had lost almost all their influence. The discredit which was thrown on the Constitution of $\mathbf{1 7 8 2}$, and the utter failure of Grattan to procure either Parliamentary reform or Catholic Emancipation, had combined, with the influences that sprang from the French Revolution, to turn many into new and dangerous paths, and to give popularity and power to politicians of another and baser type. Still, the mass of the people seem to have been but little touched, and the problem of making Ireland a loyal and constitutional country was certainly not an impossible one. But the men in whose hands the direction of affairs was placed were determined to resist the most moderate and legitimate reforms, and they made the perpetual disqualification of the Catholics and the unqualified maintenance of all the scandalous and enormous abuses of the representative system the avowed and foremost objects of their policy. Their Parliamentary majority was overwhelming, and, with the existing constituencies, there seemed no prospect of overthrowing it. Very naturally,

*Lecky, VII., pp. 205-206. 
then, the reforming energy of the country ebbed more and more away from the constitutional leaders, and began to look to rebellion and foreign assistance for the attainment of its objects" (Lecky's History of England in the Eighteenth Century, VII., pp. 270-27I).

When Parliament met on the 16th January, 1797, the Speech from the Throne dealt with the foreign situation, congratulated Ireland on the failure of the Bantry Bay Expedition, and expressed grateful acknowledgments of the loyalty of the people. An amendment, moved by Grattan, in favour of an early conclusion of the war, had only six in its support. A motion of Sir Lawrence Parsons for increasing the Yeomanry to 50,000 was rejected, but a proposal of Sir John Blaquiere to raise 10,000 for service in the British Isles exclusively was embodied in legislation, Grattan's suggestion that the service of this force should be restricted to the defence of Ireland being defeated. On February 21st, Pelham, introducing the estimates of the year, stated that the military expenses amounted to a million more than in the preceding year, and he proposed to borrow $£ 2,800,000$ and to raise $£_{305}, 000$ of additional taxes to pay the interest. This sum was to be obtained by increased duties on sugar, tea, wines, and salt, by imposing licences on malt houses, and by some slight changes in the Post Office and in the import duties. In the course of this Session the bounty on the inland carriage of corn to Dublin, which had continued since 1759 , was abandoned. The revived proposal of an imposition of two shillings in the pound on the estates of absentees was rejected by 122 to 49 , and this is said to have been the best division obtained by the Opposition during the whole Session (Lecky's History of England in the Eighteenth 
Century, VII., pp. 276-277). Lord Camden's orders from England were to prevent the passing of a measure which would have irritated powerful interests in both Houses of the British Parliament. "Ireland," writes Mr. Froude, in reference to this incident, " was sacrificed that Pitt's majority might not be weakened, and the supporters of the Castle, with bitterness at heart, were required to vote against their consciences and against what they knew to be right" (Froude's English in Ireland, III., p. 267).

On the 9th March, 1797 , Camden wrote to the Duke of Portland announcing the determination of the Irish Government to place the whole of Ulster under martial law. He stated that he had ordered General Lake to disarm the districts where outrages had been committed, to establish patrols for the arrest of all persons assembling by night, and for the prevention of meetings. "If," he adds, significantly - although armed with the powers of the Convention Act, the Insurrection Act, the Habeas Corpus Suspension Act- " the urgency of the case demands a conduct beyond what can be sanctioned by law, the General has orders from me not to suffer the cause of justice to be frustrated by the delicacy which might possibly have actuated the magistracy." Lake was, in fact, fully empowered to act as in a country under martial law. Lord Camden, in his letter to the Duke of Portland, very clearly shows that the choice of the Government lay between the reform of the Irish Parliament and the granting of Catholic Emancipation on the one hand, and government by force on the other hand, and that in the supposed interests of Great Britain the resolution had been taken of governing Ireland by force. "If," said the Lord Lieutenant, 
"I thought the United Irishmen's measure of reform in Parliament was really the remedy, and if reform could be made without shaking the connection between the Kingdoms, it might be wiser in the King's Ministers to consider whether the attempt should be made. But reform is only a popular question under which to shelter the treason which they are plotting and executing, and it would be weakness to be deceived by the pretended cause of their discontent. If Reform is resisted the kindred subject of Catholic Emancipation must be resisted also. The success of either of these questions would shake to the foundation the English interest, and as long as the present system of governing Ireland is adopted they ought not to be entertained. If a better can be devised, and there are many grievances to which the peculiar situation of this island is subject, it will have to be considered how these grievances should be remedied; but while the war lasts great and alarming discontent will appear and must be assuaged by the vigour of the Government and attention of the gentry" (Froude's English in Ireland, III., pp. 269-270). The Lord Lieutenant was under no delusion as to the momentous character of the step he was taking, and of its certain consequences. On the $13^{\text {th }}$ March, 1797 , Lake issued a proclamation at Belfast, whose palpable illegality was vehemently impugned in both the British and Irish Houses of Commons, ordering all persons in that district who were not peace officers or soldiers to bring in their arms and ammunition, and inviting information about concealed arms. Beresford, whose dismissal from office by Lord Fitzwilliam had been one of the proximate causes of that nobleman's disastrous recall from the Viceroyalty, openly avowed the policy of driving the 
people into an armed resistance. " "They must," he said, " have recourse to arms ..... he wished they were in open rebellion, then they might be opposed face to face." *

Grattan severely reprobated this language, and on March 20th, 1797, strongly urged that the irritation of Ulster would never have risen to its present height but for the flagrant corruption of the Irish Parliament and the obstinate resistance of the Government to the most moderate reform. In the Irish Parliament he was at last convinced that nothing could be done. Notwithstanding his jealousy of any proceeding calculated to encroach on the independence of the Irish Parliament, and evidenced in days past in the Commercial Propositions controversy and the Regency crisis, he now encouraged, having regard to the gravity of the situation and the hopelessness of a reform of the Irish Parliament from within, the policy of bringing Irish affairs under discussion in the British Parliament. He justified as constitutional an inquiry by a British Parliament into a conduct which tends to bring the connection into danger, the connection being a question of Empire, and a question of Empire being a question for a British Parliament. Sixteen members alone supported Grattan in a division against the Government policy, which he described as "law-making in the spirit of law-breaking " (Lecky's History of England in the Eighteenth Century, VII., pp. 288-280). A motion a few days later, instituted by George Ponsonby for the repeal of the Insurrection Act, though supported by Grattan and Curran, was equally unsuccessful. Fox, in the British House of Commons, already acting in concert with Grattan and his friends in the Irish House of

$$
\text { *Lecky, VII., p. } 288 .
$$


Commons, strongly demanded the Reform of the Irish Parliament and Catholic Emancipation. He moved an $\Lambda$ ddress to the King, praying him to take into consideration the disturbed state of Ireland, and to endeavour to tranquillise and conciliate it by healing measures. Pitt, with grim irony, opposed the motion for the Address as a violation of the independence of the Irish Parliament, whose corruption was every hour brought home to him in the course of Irish Administration, as explained to the British Cabinet by the Lord Lieutenant and the Duke of Portland. "To assent to the Address," he said, " would be highly unconstitutional with respect to Ireland, an unwarrantable interference in the duties of the legislature and executive government of that nation." "It was," writes Mr. Lecky, " a singular thing to see the founder of the Constitution of 1782 so eager to induce the British Parliament to intervene in Irish legislation, while the men who had originally opposed that Constitution, and the men who at last strangled it with corruption, stood forward as the champions of the Parliameritary independence of Ireland " (Lecky's History of England in the Eighteenth Century, VII., p. 29I).

As in the American war, so also in the system of military outrage which goaded the people into resistance, the Irish Parliament, which was so subservient to the English Government, did not reflect the views and sentiments of the Irish Protestant people. The correspondence of Lord Camden with the English Cabinet abounds in evidence of a strong desire on the part of the unbribed Irish Protestant gentry to end the reign of terror by Catholic Emancipation and a comprehensive Parliamentary reform. Lord Camden, in a " most secret" letter to the Duke of Portland, written on April I $3^{\text {th }, ~ 1797, ~}$ 
writes: "It is melancholy to observe that the most respectable part of the inhabitants of the Northern Counties are blind to their own interests .... that they are beginning to talk the language of encouragement to the pretended principles of the United Irishmen." An address to the King, carried at a large meeting convened by the High Sheriff of Armagh, is, Mr. Lecky thinks, a type of a great number of addresses and resolutions of a similar character. This address, which summarised the condition of the country, declared that the British Constitution in Ireland was enjoyed only in name; that a system of organised corruption had been established which made the Irish Parliament a mere passive instrument in the hands of the English Cabinet; that the people were being goaded to madness by accumulated oppressions; that in the richest and most prosperous provinces in Ireland military coercion had taken the place of common law, and useful citizens were dragged to the fleet without trial by jury, like the most atrocious felons. Most of the evils, the petitions said, would have been prevented if the people had been fairly and adequately represented in Parliament, and they added that the restrictions still maintained upon the Catholics were disgraceful to the age, and that the Government had been deliberately propagating religious animosities and persecutions (Lecky's History of England in the Eighteenth Century, VII., p. 321).

It was amid these surrounding circumstances that on May $5_{5}$ th the question of reform was once more introduced in the Irish House of Commons by Mr. Ponsonby in a series of resolutions embodying a scheme of reform of the representation by the removal of all religious disabilities, the abolition of the present form of returning 
Nembers for cities and boroughs, the division of counties into districts consisting of 6,000 houses each, and returning two members, a property qualification, and the enfranchisement of all freemen of cities and of all who had resided a certain number of years following a trade. 'The Government met these proposals by an adjournment, urging that they were inopportune in a time of war and social disturbance. Grattan, in a luminous speech, exposed for the hundredth time the abuse of the Irish Aciministration, the travesty of representation presented by the Irish House of Commons as then constituted, and stated plainly that the choice must be made between reform of 'Parliament and' coercion, with all its attendant horrors. He knew he was pleading to an insensate audience, and that the Parliament whose legislative independence he had secured and established was rendered impotent by corruption. "We have," he said, "offered you our measure. You will reject it. We deprecate yours. You will persevere. Having no hopes left to persuade or dissuade, and having dischargeci our duty, we shall trouble you no more, and after this day shall not attend the House of Commons."

The adjournment was carried by i 7 to 30 , and Grattan and his immediate followers left the House of Commons.* He refused to seek re-election at the ensuing general election, and came back to the House of Commons in January, I800, when the measure of the Union har! made such progress that all resistance to it was hopeless. In after years Grattan admitted that his secession from Parliament was a mistake, that he had acted in anger, and that in a long political career errors of judgment were inevitable. His secession was planned in concert with the secession from the English House of Commons of

*Lecky, VII., pp. 324-328. 
Fox on the rejection there of a measure of Parliamentary reform. Fox, however, retained his seat, but discontinued his attendance in Parliament. Grattan's " sticking to his guns," to use the words of Mr. Gladstone, might have changed the course of events. It would, in any case, have made the task of the destroyers of the Irish Parliament more difficult, and would have exposed to the contempt of the civilised world, before, perhaps, such exposure was too late, the depths of pollution in which the machinators of the Union sank in the perpetuation of that stupendous crime. Mr. Gladstone says that Grattan retrieved his error by his return to Parliament two years later. He could not, however, then remove the fatal effects of that error. The Irish Parliament, without Grattan, lost not only its most brilliant ornament, but its chief redeeming feature. His departure was an acknowledgment to his own heart-break of the failure of Parliamentary government in Ireland, to whose promotion he had devoted the best energies of his supreme political genius. Grattan's secession from Parliament was rapidly followed by a fresh proclamation issued by the Lord Lieutenant in Council placing the whole country more strictly under martial law. The proclamation, while empowering and ordering toops to suppress the conspiracy by the exertion of the utmost force, offered a free pardon to all persons who were members of the conspiracy not guilty of certain specified crimes, provided they went to a magistrate of a county before June $25^{\text {th }}$, took the oath of allegiance, and, if required to do so, gave recognisances for their future good behaviour (Lecky's History of England in the Eighteenth Century, VII., p. 338).

The Parliament, which, as we have seen, had been reduced by habitual corruption to a condition of despicable 
subserviency to the Government, invclving self-stultification, was prorogued on July $3^{\text {rd, }} 1797$, and shortly afterwards dissolved. Lord Camden's " list of honours," which he recommended the Government to confer on the supporters of the Government, in order, in his own words, " to carry into execution those promises which Government was under the necessity of contracting in the course of that Parliament," is in itself a clear proof of the methods by which Irish government was conducted. He recommended that three viscounts should be made earls, three barons viscounts, that two ladies whose husbands had been strong supporters of the Government in the House of Commons should be raised to the peerage, while six new peers and five baronets were created (Lecky's History of England in the Eighteenth Century, VII., pp. 4I2-4I3).

Grattan, who regarded a general election in Ireland as no more than an opportunity to exercise, by permission of the Army, the solitary privilege to return a few representatives of the people to a House occupied by the representatives of the boroughs, refused to stand for the new Parliament, or to change his attitude in reference to abstention from all participation in Parliamentary proceedings. In a "Letter to the Citizens of Dublin" he gave a summary of past Irish history, and repeated the arguments for Catholic Emancipation and Parliamentary Reform. He declared that since the establishment of Irish Parliamentary Independence in 1782 , the deliberate aim of the Government had been to render abortive, by methods of corruption, the Parliamentary rights which had then been nominally conceded. "The historian of these melancholy and alarming times," he said, "will, if a candid man, close the sad account by 
observing that on the whole the cause of the Irish distraction of 1797 was the conduct of the servants of Government cndeavouring to establish, by unlimited bribery, absolute power; that the system of coercion was a necessary consecuence, and part of the system of corruption, and that the two systems in their success would have established a ruthless and horrid tyranny, tremendous and intolerable, imposed on the Senate by influence and the people by arms" (Lecky's History of England in the Eighteenth Century, VII., p. 4I9).

The general election of 1797 to the last Parliament of Ireland passed off quietly. The Roman Catholics who had been admitted to the franchise had, except at byelections, no opportunity of voting for the return of candidates to the House of Commons till four years after they had been made legally entitled to do so. In accorcance with the practice of the Constitution, as observed since the Reform Act of 1832 , the admission to the franchise of a large contingent of new voters is invariably followed by a general election, in order to enable the House of Commons to be a reflection of the wants and wishes of the electorate. It should, moreover, be borne in mind, at a time when the doctrine of the Parliamentary mandate is much pressed, that the House of Commons of the Irish Parliament which carried the Union had no mandate from the electors of any kind with reference to that question, which was not mooted during the election, and never mooted as a measure of Government policy till November, I798. It is, moreover, no exaggeration to say that the General Election in 1797 to the Irish House of Commons of the Irish Parliament by which the Union was carried, in those constituencies in which there was even a semblance of representation, took 
place in a period of disturbance amounting to civil war. "The Great Irish Rebellion of the eighteenth century is," writes Mr. Lecky, " always called the Rebellion of 1798 , but the letters from Ulster in the spring and summer of 1797 habitually speak of the province as in a state of real though smothered rebellion, and the measures superseding civil by military law were justified on that ground " (Lecky's History of England in the Eighteenth Century, VII., p. 294). Mr. Lecky's description of the state of Ulster in 1797 is applicable, with very slight modifications in the case of strictly limited areas, to all Ireland at that time.

So far back as May, 1797 , the great post of Commander of the Forces in Ireland was pressed on the acceptance of Lord Cornwallis, who, however, declined it, and would not be induced to change his mind by the desire of Lord Camden to resign the Lord Lieutenaricy so as to enable the position of Lord Lieutenant and Commander of the Forces to be held by Lord Cornwallis in conjunction. Lord Camden, while not in any way deprecating the dreadful military excesses which marked the régime of Lord Carhampton as Commander of the Forces, assisted by General Lake, in Ireland, felt that the Command should be filled by a soldier of more military capacity and administrative power than Lord Carhampton, who had become a very hateful figure in Irish public life. $\mathrm{He}$ was accordingly transferred to the position of Master of Ordnance in England, and Sir Ralph Abercromby succeeded him in the Irish Command in November, 1797. He was a gentleman of the very highest military distinction, and, like Sir John Moore and Sir John Burgoyne, was a Member of the British House of Commons. He was proud of the Army, and determined to uphold its 
traditions. In a tour made through the south of Ireland almost immediately after his appointment, he was shocked at the lack of discipline shown by the troops, and at the timidity of the Irish gentry, who, instead of utilising the Yeomanry for such purposes, " ruin the troops by calling on them upon every occasion to execute the law and to afford them personal protection." He came to the conclusion that the state of the country was not so alarming as he had been led to believe, and he expressed his determination to stop the military outrages, which in some cases had been perpetuated at the instigation of Government officials, by issuing an order reminding officers that though they might sometimes be called on to aid the magistrates, they must not forget that they are only called on to support the laws of the land, and not to step beyond the bounds of them. Any outrage or excess, therefore, on their part he deemed to be highly culpable, and they are strictly enjoined to preserve the greatest moderation and the strictest discipline when they are called on to exercise this part of their duty (Lecky's History of England in the Eighteenth Century, VII., p. 428). The new Irish Parliament met on January 9th, 1798. Grattan, Ponsonby, and Curran were no longer members. The defence of popular rights and liberties was well maintained by Sir Lawrence Parsons and Messrs. Knox and Brown, the members for Trinity College, Dublin, who were magnificently aided by Plunket, whose name was destined to be associated with the cause of Catholic Emancipation in the Imperial Parliament, and by Charles Kendal Bushe, eventually Lord Chief Justice of Ireland, a very brilliant and powerful orator. Abercromby's determination to put down the system of military outrages gave increased emphasis to the strong representations 
of the friends of the people in both Houses of Parliament with reference to these outrages and the state of terror thereby produced. Lord Moira, in the Irish House of Lords, gave a description of the horrors he had himself witnessed in Ireland, which was in large measure a repetition of his speech in the British House of Lords in the November previous. Mr. Lecky regards in a serious light the charges brought against the military in Ireland by Lord Moira, who was himself a distinguished military man, who had held an important command in the American War, and was subsequently, as Marquis of Hastings, Governor-General of India. "We have," he writes, "abundant evidence that great numbers of poor men's houses were at this time burnt on slight reasons and without a shadow of legal justification, and there is much reason to believe that in the midnight raids many persons were shot at by soldiers, or more probably by yeomen, in a manner that differed little, if at all, from simple murder" (Lecky's History of England in the Eighteenth Century, VII., pp. 300-307).

The strong condemnation of military insolence by Lord Moira in the Upper House had its echo in the Lower House of the Irish Parliament. Sir Lawrence Parsons moved for a Committee of the House to inquire into the state of the Nation, a motion which was rejected by ${ }^{5} 6$ to 19. In his speech made in support of that motion he said that to make the people respect the laws the Government should itself obey them. Such had not been the conduct of the Government, and to that misconduct were the outrages and assassinations, which had disgraced the country, to be traced. A general officer had, in a certain district, taken out of the gaols a number of prisoners, whom the law would perhaps have pronounced 
innocent, and by his own authority transported them (Lecky's History of England in the Eighteenth Century, VII., p. 442).

The attitude of the Irish Patriot Party found most powerful support and confirmation in an unexpected quarter-the famous general orciers issued on February 26th, I798, at Sir Ralph Abercromby's instance from the Adjutant General's Office : "The very disgraceful frequency of Courts Martial, and the many complaints of irregularities in the conduct of the troops in this Kingdom," they said, " having too unfortunately proved the Army to be in a state of licentiousness, which must render it formidable to everyone but the enemy, it had become necessary to enjoin all commanding officers ' to compel from all officers under their command the strictest and most unremitting attention to the discipline, good order and conduct of their men, such as may restore the high and distinguished reputation the British troops have been accustomed to enjoy in every part of the world. ' It becomes necessary,' the writer added, ' to recur, and most pointedly to attend, to the Standing Orders of the Kingdom, which, at the same time that they direct military assistance to be given at the requisition of the civil magistrate, positively forbid the troops to act (but in case of attack) without his presence and authority, and the most clear and precise orders are to be given to the officer commanding the party for the purpose.' '

These orders, which were in direct conflict with the proclamation of May 18 th, 1797 , by which the military were instructed to act without waiting for the civil magistrate, created great distress and indignation in Irish official circles. No immediate stricture, however, was made on the action of Sir Ralph Abercromby, which 
was severcly reprobated in private. Pelham, the Irish Chicf Secretary, justified Abercromby completely in Parliament, but the Lord Chancellor, the Speaker, Mr. Beresford, and the official clique who had procured the recall of Lord Fitzwilliam, determined that they would likewise get rid of Abercromby. The Speaker, standing at the Bar of the House of Lords to deliver the Money Bills, took occasion in his Address to the Lord Lieutenant to commit the House of Commons against Abercromby by expressing the full confidence of the House in the high discipline of the Army. Lord Auckland, who, as Mr. Eden, had been Chief Secretary for Ireland in Lord Carlisle's Viceroyalty in 1781 , had formed intimacies and lasting associations with Lord Clare, the Lord Chancellor, Mr. Beresford, and Mr. Cooke, the Under Secretary, with whom he was in constant correspondence. The substance of their communications was given to Mr. Pitt and the Duke of Portland for the purpose of affecting their minds, independently of the representations of Lord Camden and Mr. Pelham. Lord Camden told Sir Ralph Abercromby the gist of an angry letter written to him by the Duke of Portland in reference to these orders. The Lord Lieutenant, who wished Abercromby to remain in command, endeavoured to be conciliatory, and to render the situation less acute. $\mathrm{He}$ did not wish Abercromby to resign, knowing the effect on public opinion of such a step. Sir Ralph Abercromby, the moment he received Lord Camden's letter, sent in his resignation, and was proof against all efforts, however earnest, to induce him to re-consider his position. Camden urged that the proclamation of the 18th May, under which the military received orders to act without waiting for a magistrate, was, contrary to Abercromby's 
opinion, still in force. Abercromby, though he refused to withdraw his resignation, spoke with great personal warmth and respect of Lord Camden, and consented, before leaving the country, to revoke the chief part of his general orders, and himself to go armed with the full forces of martial law to quell certain disturbances which had arisen in some counties of Leinster and Munster (Lecky's History of England in the Eighteenth Century, VII., pp. 430-436).

" The struggle," wrote Abercromby, in a private letter, " has been, in the first place, whether I was to have the command of the Army really or nominally, and then whether the character and discipline of it were to be degraded and ruined in the mode of using it, either from the ferocity of one man or from the violence and oppression of a set of men who have for more than twelve months employed it in measures which they durst not avow or sanction. . . . . Within these twelve months every cruelty that could be committed by Cossacks and Calmucks has been transacted here. The words of the order of February 26th were strong: the circumstances required it " (Lecky's History of England in the Eighteenth Century, VII., pp. 433-434.)

"Many and various influences," writes Mr. Lecky, " concurred to produce, accelerate, and extend the insurrection of 1798 , but among them the burning of houses and other lawless acts of military violence, which were countenanced by the Government, had an undoubted part. The resignation of a Commander-in-Chief, mainly because he endeavoured to repress them, and because he had been censured for that endeavour, was one of the most calamitous events that could at this time have happened" (Lecky's History of England in the Eighteenth 
Century, VII., pp. 435-436). Again: “Abercromby is nearly the last figure of any real interest that in the eighteenth century flitted across the troubled scene of Irish politics. He left Ireland before the end of April, 1798, just a month before the Rebellion broke out, and he was replaced by Lake, who, more perhaps than any other military man, was associated with the abuses which Abercromby had tried to check. The reign of simple force was established beyond dispute, and the men whose policy had driven Lord Fitzwilliam from Ireland and Grattan from Parliament were now omnipotent" (Lecky's History of England in the Eighteenth Century, VII., p. 438).

The efforts of the Opposition in the Irish House of Commons to impose some restraints on the military violence reprobated by Sir Ralph Abercromby were, of course, futile. A new Indemnity Act (37 Geo. III., c. 39) was carried, which sheltered all magistrates and other persons employed to preserve the peace from the consequences of every illegal act they had committed since the beginning of the year 1797 with the object of suppressing insurrection, preserving peace, and securing the safety of the State. A clause, of which Plunket was the proposer, for granting compensation to the innocent victims of military violence, was opposed and rejected (Lecky's History of England in the Eighteenth Century, VII., pp. 445-446). An Absentee Tax, for the purpose of preventing the exemption of the great absentee proprietors from all taxation for Iish purposes, was defeated by 104 to 40 , while the salt tax and the leather tax were falling with great severity on the poor, and in the City of Dublin no fewer than 37,000 persons were in a state of extreme destitution. The Government, who, 
in obedience to the peremptory orders of the Duke of Portland, opposed the Absentee Tax, deemed it necessary to raise nearly four millions by loan, and found the operation exceedingly difficult. They were obliged to issue five per cent. $f_{100}$ debentures at 63 , and they obtained, with some difficulty, a loan of a million and a half from England (Lecky's History of England in the Eighteenth Century, VII., pp. 447-448). 


\section{XXIII.}

\section{THE INSURRECTION OF I798 IN I'TS BEARING}

\section{ON THE UNION.}

THE history of the Insurrection of 1798 does not, as I have said, come within the scope of this work, except in relation to the effect produced thereby on the Irish Parliament. That the Rebeliion was one of the principal factors in the accomplishment of the Union is universally admitted. A matter which is, however, sometimes traversed-that the people were deliberately goaded by a series of military severities into an insurrection which could have been instantly suppressed, but was allowed to develop into a movement extinguishable only by bloodshed, so that the terror produced by that bloodshed should be utilised for the destruction of the Irish Parliament-is, in my judgment, likewise unquestionable. On the 22nd April, 1834, Mr. O'Connell, who had grown up to manhood in the life of the Irish Parliament, made, without fear of contradiction in the House of Commons, entering into details, the terrible charge, which he repeated in Dublin in 1843 in a speech to which I have previously referred, that the English Government had intentionally stimulated the Irish people into rebellion in order to pave the way for the Union. " He would," he said, " establish to demonstration that there would have been no rebellion if it were not to carry the Union. That rebellion was purely Jacobinical in its origin, but at its close it was disguised by religious rancour and made the instrument of splitting the people into hostile factions. It at first 
originated with the Presbyterians of the North, it then spread over the country, embracing men of all parties and creeds, and it was for the sake of carrying the Union that it was made to explode. What was the proof ? The Government had clear evidence of what was going on, and could at any time check it, but no! in place of arresting the chiefs and seizing their papers, they allowed things to ripen and the people to be goaded by petty tyranny into open revolt, and what, then, was the terrible consequence ? He had heard of such things, as who had not, of free quarters, of torture, and of picketing. All these were the work of the Irish Government of those days, in order that they might enslave the country. In the year $\mathrm{x} 797$ the military command was entrusted to the gallant Abercromby, who was no party man, and from whom, therefore, truth might be expected. He found the Army demoralised and disorganised, and on the 26th February of that year he published his famous General Orders, in which he stated the memorable fact that 'the Army was formidable to all but to the enemies of the country.' That was a fact which was not denied, and was undeniable. Against a foreign foe they were contemptible, though to the Irish people they were a dreadful scourge. The facts, he knew, had been asserted in the Irish House of Commons. He asserted in that House that the object of the Government was to make the Irish Rebellion explode for the purpose of carrying the Union. His authority was not common report, but a Report of the Secret Committee of the Irish House of Commons in 1798. In Section 19 it was stated that a man named Nicholas Maguan, who was a Colonel of the Insurgent Army and a member of the Provincial Committee, attended the meetings and regularly entered into the 
debates, and, after the business of the meeting, went to a neighbouring magistrate, the Rev. Mr. Clelland, who was now alive, and gave the names of the parties, with an account of all the proceedings. This was in 1797. This information was duly transmitted to the Government, who did not act on it, but allowed matters to go on till 1798 , when they were ripe for their purpose. The Ministers then had all the necessary information in their possession for twelve months, yet they made no effort to check the march of rebellion, but, on the contrary, many efforts to expedite and facilitate it. They had a large army, but they did not, however, apprehend the danger to be as great as it was. They miscalculated grossly the amount of physical force and the popular energy and moral intelligence arrayed against them, and were nearly falling into the pit they prepared for the people. The outbreak in Wexford was not the result of the concerted scheme of the leaders of the Rebellion, but was caused by wanton and premeditated cruelties practised in order to precipitate things to a crisis before the schemes of the leaders were matured. There would have been no Union but for the Rebellion, and no Rebellion but for the Union. The Rebellion was destined to usher in the monster of the Union, that engine of English domination. But a rebellion was necessary to excite bigotry and foster religious animosity. It was a measure that was floated into the temple of the British Constitution on the blood of Irishmen. How was the Union procured but by the familiar use of torments, by the terror inspired by a military force amounting to 129,000 men, each of whom was judge, sheriff, and cxecutioner, and by drum-head courts-martial ? Let the House hear what Lord (Chancellor) Plunket said on that 
subject: 'I will be bold to say that licentious and impious France, in all the unrestrained excesses which anarchy and atheism have given birth to, has not committed a more insidious act against her enemy than is now attempted by the professed champion of civilised Europe against a friend and an ally in the hour of her calamity and distress, at a moment when our country is filled with British troops, when the loyal men of Ireland are fatigued and exhausted by their efforts to subdue rebellion-efforts in which they had succeeded before these troops arrived-whilst our Habeas Corpus Act is suspended, whilst trials by courts-martial are carrying on in many parts of the Kingdom, whilst the people are taught to think they have no right to meet or to deliberate, and whilst the great body of them are so palsied by their fears and worn down by their exertions that even the vital question is scarcely able to rouse them from their lethargy, at a moment when we are distracted by domestic dissensions-dissensions artfully kept alive as the pretext of our present subjugation and the instrument of our future thraldom.' It might be asked, why did not the people oppose the Union? why did they concur in the measure ? He (Mr. O'Connell) would put it to English gentlemen to make it their own case, and then make allowance for the people of Ireland, especially the Catholics. If they opposed it, they would be accused as rebels; if, as Catholics, they resisted it, then they would be stigmatised as setting themselves against the Protestants. He implored the House not to dismiss this part of the case from their minds until they understood it. Here the Government had all the information in their power necessary to crush the Rebellion in its infancy, yet they did not crush it. Why not arrest 
the leaders in time and strike a timely blow for the restoration of allegiance ? Merely that they wished to foster it to a certain extent, that they might make disaffection an excuse for robbing the country of its freedom."

The Life of Grattan, by his son, who was himself an eminent Member of the House of Commons, Mr. Lecky regards as the very best history of Ireland of the period to which it relates. This work was published in volumes, which were produced between the years i $\delta 39$ and 1846 , long after O'Connell's statement. The younger Grattan relates the following anecdote of John Scott, first Earl of Clonmell, who was Lord Chief Justice of Ireland from 1784 till his death in 1798 : "Shortly before his death," writes Mr. Grattan, "Lord Clonmell sent for his nephew, Dean Scott; got him to examine his papers, and destroy those that were useless. There were many relating to politics that disclosed the conduct of the Irish Government at the period of the disturbances of 1798. There was one letter in particular which fully showed their duplicity, and that they might have crushed the Rebellion, but that they had let it go on on purpose to carry the Union, and that this was their design. When Lord Clonmell was dying he stated this to Dean Scott, and made him destroy the letter; he further added that he had gone to the Lord Lieutenant (Lord Camden) and told him that, as they knew of the proceedings of the disaffected, it was wrong to permit them to go on, that the Government, having it in their power, should crush them at once and prevent the Insurrection. $\mathrm{He}$ was coldly received, and found that his advice was not relished. That of Lord Clare, Mr. Speaker Foster, and Archbishop Agar (Lord Normanton) had predominated, and, in consequence, he was not summoned to attend the Privy 
Council on business of State (his health not being good was advanced as the excuse). On ordinary affairs, however, he still received a summons." "Dean Scott," the younger Grattan adds in a note, "was married to Mr. Grattan's niece, and he (Dean Scott) communicated this statement with the knowledge that it would be made use of in a work of this nature, but he would neither disclose the name of the person who wrote this letter nor more of its contents" (Grattan's Life, II., pp. 145-147).

Sir Jonah Barrington, who was a King's Counsel, a Judge of the Court of Admiralty in Ireland, a member of the Irish House of Commons, and a vehement opponent of the Union, writing in testimony of what he had seen, says : "Mr. Pitt counted on the expertness of the Irish Government to effect a premature explosion. Free quarters were ordered to irritate the Irish population; slow tortures were inflicted under the pretence of forcing confessions; the people were goaded and driven to madness . . . . Mr. Pitt's object was now effected, and an insurrection was excited." " Free quarters,' 'writes Sir Jonah Barrington, " is a term not yet practically known in England. Free quarters rendered officers and soldiers despotic masters of the peasantry, their houses, food and property, and occasionally their families. This measure was resorted to with all its attendant horrors throughout some of the best parts of Ireland previous to the Insurrection, and for the purpose of exciting it."

Mr. Lecky says that it has often been asked why the Irish Government, with all the information at its disposal, and at a time when the Habeas Corpus Act was suspended, did not arrest the leading members of the conspiracy before it had attained its height. He palliates this conduct by the statement that, while most of the schemes of 
the United Irishmen were communicated to the Government, and while they had a general knowledge of the leading members of the conspiracy, they appear to have known little about the Supreme Executive, and they were conscious they could produce no evidence against the leaders which was the least likely to lead to a conviction. If this were the case, and the evidence seems to be strongly against this supposition, with the Habeas Corpus Act suspended, with a Parliament which had passed an Insurrection Bill and an Indemnity Bill, which was prepared to give them any power for which they asked, and to sanction any illegality with free quarters, house burnings, tortures, military executions, deportations to the fleet, which were the unceasing accompaniment of their régime, it is quite certain their failure to arrest the leaders till the time at which the Rebellion was ripe for explosion was due to some deep and premeditated purpose, and is only explicable on the ground that an outburst of rebellion, deliberately provoked and savagely repressed, was regarded by the terrorism and confusion thereby created as a condition precedent to a successful effort for the destruction of the Irish Parliament. Lord Camden, who was considered by Lord Clonmell to receive coldly his remonstrances at not crushing the conspiracy when it was in his power to do so, was at first inclined to take this course, which was approved by his advisers in Ireland, but he was peremptorily precluded from taking such action by the English Cabinet.

On February 8th, 1798, Lord Camden informed the Duke of Portland that the confidential friends of the Government in Ireland had unanimously agreed that it was very advisable to crush at once the leaders of the conspiracy, even though it was probable that no sufficient 
evicience could be produced to justify a trial. Such an arrest, they contended, would dislocate the conspiracy, and, if it produced an insurrecton in some parts of the kingdom, the event might not be unpropitious, as it would be more in our power to crush it than if such an event happened when the enemy were off the coast. Portland, however, answered that such a policy would be rash and dangerous, and he positively forbade it (Lecky's History of England in the Eighteenth Century, VIII., p. 9). When the leaders were, in some cases, arrested, matters had reached a crisis at which armed resistance by the people to the Government, whose deception and persecution had maddened them, had become inevitable.

The Rebellion broke out on May 23rd, 1798. Edward Cooke, the Under Secretary in Dublin Castle, who was one of the principal machinators of the Union, writing three days afterwards, on the 26th May, 1798, said : "I consider this insurrection, however distressing, as really the salvation of the country. If you look at the accounts that 200,000 men are sworn in a conspiracy, how could that conspiracy be cleared without a burst? Besides, it will prove many things necessary for the future settlement of the country when peace arises" (Lecky's History of England in the Eighteenth Century, VIII., p. 63). Lord Cornwallis, who succeeded Lord Camden in the Irish Viceroyalty as Lord Lieutenant, and united with that office the position of Commander of the Forces in Ireland, arrived in Dublin on June 2oth. He had been only a few days in Dublin when he gave the following description of the tone of feeling between class and class produced by the Rebellion, and of its probable influence in the achievement of the destruction of the Irish Parlia- 
ment: "The violence of our friends," he writes, " and their folly in endeavouring to make it a religious war, added to the ferocity of our troops, who delight in murder, most powerfully counteract all plans of conciliation. The minds of the people are now in such a state that nothing but blood will satisfy them, and, although they will not admit the term, their conversation and conduct point to no other mode of concluding this unhappy business than that of extirpation. The conversation even at my table, where you will suppose I do all I can to prevent it, always turns on hanging, shooting, burning, etc., etc., and if a priest has been put to death the greatest joy is expressed by the whole company. So much for Ireland and my wretched 'situation.' The life of a Lord Lieutenant of Ireland comes up to my idea of perfect misery, but if I can accomplish the great object of consolidating the British Empire, I shall be sufficiently repaid" (Cornwallis Correspondence, II., pp. 355-357, 369-372).

Mr. Lecky observes that these last lines, which were written as early as July Ist, I798, probably, I should say most positively, point to a design which was already formed of pushing forward a Legislative Union. (See Lecky's History of England in the Eighteenth Century, VIII., p. 183.)

The Rebellion, which was excited for the destruction of the Irish Legislature, and which contributed so powerfully to that destruction, rendered the Irish Parliament still more subservient to the British Government, on which it relied for the preservation not only of its own corrupt constitution, but of the property, more especially the land, of the privileged ascendancy class, of which its members were composed. The Rebellion had its origin 
in the change in the Society of United Irishmen from a constitutional organisation, framed for the purpose of gaining popular rights and privileges, into a revolutionary organisation, owing to the persistent denial of concessions whose justice was unquestionable, and the promise of Catholic Emancipation, made only to be broken. The Irish Parliament, amenable at all times to the British Government, except when their pride in being an independent legislative body was in any degree wounded, now, in what they regarded as a matter of life or death to their own class, vied with the Government in the adoption of a policy of the utmost severity in dealing with the insurgents, and enthusiastically accepted every Government suggestion for the suppression of the Rebellion. The feelings of the insurgents towards the Irish Parliament were well known. They had been inherited from the United Irishmen. On the I8th May, I798, the trial of the Earl of Kingston by the House of Peers for wilful murder, which terminated in an acquittal, would have been the occasion for an attack on the Chamber and assembled Peers if the proposal had not been defeated by the casting vote of an informer in the pay of the Government. The seizure of Dublin Castle was then resolved on-a plan which was instantly betrayed by the same informer. On the 22nd May, Lord Castlereagh announced to the House of Commons the discovery of a plot for placing Dublin in the hands of a rebel force and for seizing the Executive. The House responded with a loyal address, and all the Members, with the Speaker and the Serjeant-at-Arms at their head, walked two and two through the streets to present it to the Lord Lieutenant (Lecky's History of England in the Eighteenth Century, VIII., p. 52). The proclamation issued by the 
Lord Lieutenant, commanding His Majesty's forces to punish all persons acting, aiding, or in any way assisting in the Rebellion according to martial law, " either by death or otherwise as they shall deem most expedient," was laid before the House of Commons and unanimously sanctioned. One Member even spoke of giving it a retrospective action and executing under it the political prisoners who were now under arrest, but the atrocious suggestion, though it was received with some applause, was not pressed to a division (Lecky's History of England in the Eighteenth Century, VIII., p. 6r).

The clemency of General Dundas in allowing a body of insurgents to lay down their arms and disperse was vehemently denounced in the Irish House of Commons, while a vote of thanks was moved to Sir James Duff, whose troops had killed, at a place called Gibbet Rath, in the Curragh of Kildare, between 200 and 300 men who had surrendered their arms to General Dundas. On June 27 th the Irish Parliament voted $£ 500,000$ for the maintenance of British troops in Ireland. On July $3^{\text {rd }}$ a proclamation was inserted in the Dublin Gazette authorising the King's Generals to give protection to such insurgents as, having been guilty merely of rebellion, deserted their leaders and took the oath of allegiance. On the 17 th July a message from the Lord Lieutenant, signifying His Majesty's pleasure to that effect, was delivered to the House of Commons, and an Act of Amnesty was speedily carried in favour of all rebels, with certain specified exceptions, who complied with these conditions (Geo. III., c. 55). (Lecky's History of England in the Eighteenth Century, VIII., pp. 185-186.)

The vindictive tendencies of the section of the Irish House of Commons who more particularly were asso- 
ciated with the maintenance of privilege and of corruption were manifested in the motion of Mr. John Claudius Beresford for leave to bring in a Bill to confiscate the properties of men convicted of high treason before a court martial, as if such a conviction had taken place before a civil tribunal. Lord Castlereagh opposed the motion on the ground that the measure contemplated would more properly be introduced on the initiative of the Government. A Bill of Attainder was subsequently introduced by the Government confiscating the property of Lord Edward Fitzgerald, who had died of wounds inflicted on him when resisting arrest on a charge of high treason, and of Bagenal Harvey and Cornelius Grogan, gentlemen of large estates, who had been tried by court martial and executed. The thanks of Parliament were voted to the yeomanry, the militia, and the other troops, and a sum of $f_{100,000}$ was voted to the loyalists who had suffered during the Rebellion. The claims sent in by the loyalists amounted to $\AA^{823,517}$. Between December, 1797, and August, 1798, Ireland borrowed no less than $£ 4,966,666$, nearly all of it at more than $£^{6}$ per cent., and a large proportion at more than f7 percent (Lecky's History of England in the Eighteenth Century, VIII., p. 254). The ferocious passions evoked by the Rebellion in the combatants on both sides, and the mutual hatred between Protestants and Roman Catholics, which were its calculated results, were painfully apparent. That the Irish Parliament represented the views of the ascendancy party throughout the country, and was amenable to its pressure, irrespective even of the influences of the Government, is, I think, demonstrated by its conduct and legislation during the Rebellion of 1798, and at its conclusion. Lord Cornwallis's lenity 
to rebels was the subject of severe reprobation in loyalist circles, both in England and Ireland ; on the one hand, because it was calculated to make the position of Protestants so unpleasant as to make them anxious for a Union, and, on the other hand, because it was likely to retard that measure. The Lord Lieutenant's condemnation of a court martial presided over by Lord Enniskillen, which acquitted a yeoman clearly guilty of an atrocious murder, was the subject of scathing criticism. "Lord Cornwallis's severe censure on Wollaghan's court martial," writes Sir George Hill, an Irish place-beggar and Castle sycophant, "is universally brought against him in all companies as indicating a determination on his part to render the kingdom upon system uncomfortable for the Protestants and thereby to force them to become solicitors for a Union. The devil of this language is that it is held by the most approved friends of the Government" (Lecky's History of England in the Eighteenth Century, VIII., pp. 252-253).

Lord Camden, Lord Cornwallis's predecessor in the Lord Lieutenancy, in a letter to Lord Castlereagh, condemns Lord Cornwallis's censure on the Wollaghan court martial as calculated to injure the prospects of the Union. "That the violence of some of the partisans of the Protestant interest should be repressed I believe you know I sincerely think, but that a condemnation of them should take place will infinitely hurt the English interest in Ireland. .... The great question of Union will be hurt by this measure, as, however unjustly, it will indispose, I fear, a very important party to whatever seems to be a favourite measure of Government" (Castlereagh Correspondence, I., pp. 425-426 ; Lecky's History of England in the Eighteenth Century, VIII., p. 24I). 


\section{XXIV.}

\section{PREPARING THE IRISH PARLIAMENT FOR}

\section{THE UNION.}

I HAVE endeavoured to sketch in outline the condition of Ireland at the time the measure of Union was proposed to the Irish Parliament by the English Cabinet. Lord Cornwallis, writing to Lord Castlereagh on the $14^{\text {th }}$ January, 1801, after the Union had come into operation, bears testimony to the fact that the Rebellion, by the terrorism it had created, " assisted the Union." " Timid men," he proceeds, "will not venture on a change of system, however wise and just, unless their fears are alarmed by passing dangers" (Cornwallis Correspondence, III., pp. 331-332). On the 7th September, I798, before any authoritative announcement of the adoption by the Government of a policy of Union, Lord Castlereagh informed Mr. Pitt in a letter marked "private": "The force that will be disposable when the troops from England arrive cannot fail to dissipate every alarm, and I consider it peculiarly advantageous that we shall owe our security so entirely to the interposition of Great Britain. I have always been apprehensive of that false confidence which might arise from an impression that security had been obtained by our own exertions. Nothing could tend so much to render the public mind impracticable with a view to that future settlement, without which we can never hope for any permanent 
tranquillity." During the whole of the eighteenth century, before the war of 1793, Ireland had contributed largely and liberally, and much beyond the stipulated proportion, to the support of English wars undertaken for objects of English policy, while crowds of Irish recruits had filled the British Army and the British Fleet. "For the first time," writes Mr. Lecky, "the parts had been reversed. The Irish loyalists had been compelled to ask for English assistance upon land, and this obligation was at once pressed on them as an argument for demanding the surrender of their legislature" (Lecky's History of England in the Eighteenth Century, VIII., pp. 299-300). In reality, the suppression of the Rebellion had been left to Irish resources; the English troops did not arrive till after the Rebellion had been effectively broken, and these troops were then utilised for the purposes of the Union. "There is something," says Mr. O'Connell, "which bespeaks a foregone conclusion with reference to the carrying of the Union when we look to the military force in Ireland. In 1797 , when Ireland was threatened with a rebellion, the military force was but 78,995 ; in 1798 , when a rebellion actually raged, it was 91,995 ; in 1799, after the rebellion was over, it was 114,052 ; and in 1800 , two years after the rebellion, when the Union was carried, it increased to $129,25^{8}$ soldiers, or what Lord Strafford called 'good lookers on" " (Debate in the Dublin Corporation on Repeal of the Union, p. 43).

"It is not possible," said Mr. Sheridan in the English House of Commons on January 23rd, 1799, " that, in the present state of Ireland, the people can declare and act upon their genuine sentiments; and let any man who has a head to conceive and a heart to feel for the miseries 
of Ireland put this memorable question to himself : ' Is it possible that the fair and unbiassed sense of the people of Ireland can be collected at this time on this question ?' The English force in the country is at once an answer to this question." In the tracing of the principal steps taken to carry the Union, some facts governing the whole situation must be carefully borne in mind. A Parliament elected in 1797 , "when there was no question of a Union, transferred its own rights and the rights of its constituents to another Legislature, and the act was accomplished without any appeal to the electors by a dissolution " (Lecky's History of England in the Eighteenth Century, VIII., p. 32I). The disposition of the peopie is, moreover, conclusively proved by the prominent features of the correspondence of the period, of which one was the acknowledged necessity of keeping an immense English force in Ireland for the purpose of guarding not merely against a foreign enemy, but also against the dangers to be apprehended in carrying the Union. "All thoughts," writes Lord Cornwallis, " of uniting the two kingdoms must be given up if that force should now be withdrawn," and the other feature of this correspondence was the confession of Lord Castlereagh, that " nothing but-an /established conviction that the English Government will never lose sight of the Union till it is carried would give the measure a chance of success." (See Lecky's History of England in the Eighteenth Century, VIII., pp. 327-328.)

The proposal, moreover, of a Union came not from Ireland, but from England. The Union was essentially the policy of English statesmen, aided in Ireland by Lord Clare and Lord Castlereagh. A rumour that a measure of Union was in contemplation led to a 
serious riot in Dublin in 1759, which was signalised by the invasion of the mob into Parliament House Grattan, in 1785 , denounced, as we have seen, the Commercial Propositions as " an incipient and creeping Union." The scheme of carrying the Union was considered impracticable till the rebellion brought it within the domain of practical politics. On June $4^{\text {th }}, 1798$, Pitt wrote to Lord Auckland, who, as Mr. Eden, had been Chief Secretary in $178 \mathrm{I}$, that he had been discussing with Lord Grenville the expediency of taking steps for the carrying of a Union after the suppression of the rebellion. Auckland, according to his custom, seems to have communicated on this subject with Lord Clare, who states, in a letter in reply, that he had pressed the project on Mr. Pitt's consideration since I793. "I pressed it," he said afterwards in his speech on the Union, "without effect, until British Ministers and the British nation were roused to a sense of their common danger by the late sanguinary and unprovoked rebellion."* Lord Clare, with the knowledge of the Lord Lieutenant, left Dublin for London on October 8th, I798, to discuss with Pitt the question of the Union, and came back to Ireland, having convinced Pitt of the necessity of the measure, and of its being brought forward " unencumbered with the doctrine of emancipation." $\dagger$ Rumours of these interviews and negotiations and of their objects could not fail to reach the public. On October 16 th, 1798 , Faulkner's Fournal, the official organ of the Government, whose proprietor was a Mr. John Giffard, a person of tarnished reputation, notoriously in the pay of the authorities at Dublin Castle, and known to the populace as the " Dog in Office," published-no doubt by orderthe following paragraph embodying a deliberate falsehood:

$$
\text { *Lecky, VIII., p. 28-. † †ecky, VIII., p. } 293 .
$$


"A most insidious and unadvised rumour of an intended Union with Great Britain has been set afloat by the Jacobin prints of this city in order to do the little mischief which remains in their power to achieve. .... Perilous and perplexed would be the discussion of so momentous a question at any period, but at this time of convulsion the dangers with which it would be attended are too fearful for contemplation." *

On October 16 th, 1798 , the very day on which this denial that any scheme of Union was in contemplation appeared in the official organ of the Irish Government, Lord Clare wrote from Londion to Lord Castlereagh : "I have scen Mr. Pitt, the Chancellor, and the Duke of Portland, who feel very sensibly the critical position of our damnable country, and that the Union alone can save it. I should have hoped that what had passed would have opened the eyes of every man in England to the insanity of their past conduct with respect to the Papists of Ireland, but I can very plainly perceive that they are as full of their Popish projects as ever. I trust, and I hope I am not deceived, that they are fairly inclined to give them up and to bring the measure forward unencumbered with the doctrine of emancipation. Lord Cornwallis has intimated his acquiescence on this point. Mr. Pitt is decided upon it, and I think he will keep his colleagues steady. If $I$ have been in any way instrumental in persuading the Ministers here to bring forward this very important measure unencumbered with a proposition which must have swamped it, I shall rejoice very much in the pilgrimage which I have made" (Castlereagh Correspondence, I., pp. 393-394). A month later, on November 17 th, although the scheme had then been revealed to leading persons in Ireland, including the * Lecky, VIII., pp. 297-298. 
Speaker, Sir John Parnell, Mr. Beresford, Lord Pery (a former Speaker), Lord (Chief Baron) Yelverton, the Chief Justices of the King's Bench and the Common Pleas, and several other persons, Faulkner's Fournal again expressed its entire disbelief in the rumours of a Union, but on November $27^{\text {th }}$ it inserted a notice, which had appeared in The Times of November 22nd, stating that a Union would be brought forward, and added that it had reason to believe this paragraph to be true. (See Lecky's History of England in the Eighteenth Century, VIII., p. 298.)

The Government calculated that if they pressed on the Union with the exercise of the usual means of influencing votes in Parliament, they would have in its favour a large section of Protestant support owing to the terror produced by the rebellion, and a large measure of Catholic support owing to the resentment the treatment of the great mass of the inhabitants of the country by an ascendancy party, once termed by Lord Clare " a puny and rapacious oligarchy," had most naturally produced. The success of the measure, Pitt thcught, would largely depend on the conduct of a few individuals in Ireland. $\mathrm{He}$ recommends Lord Cornwallis, for instance, in a secret letter dated November 17 th, 1798 , to endeavour to bribe Mr. Foster, the Speaker of the House of Commons, who was, however, proof against temptation. "It would," he writes, " as it seems to me, be well worth while for this purpose (of making the Union palatable to the Speaker personally) to hold out to him the prospect of an English Peerage, with, if possible, some ostensible situation and a provision for life, to which he would be naturally entitled on quitting the Chair." In this letter there are the following precise directions from Mr. Pitt to 
bribe the rank and file of the House of Commons : "In the interval previous to your Session there will, I trust, be full opportunity for communication and arrangement with individuals on whom I am inclined to believe the success of the measure will wholly depend " (Cornwallis Correspondence, II., p. 440). The bribery of the Press and the hiring of pamphleteers in advocacy of the Union were vigorously undertaken. Lord Castlereagh writes in November, 1798: "The principal provincial papers (have been secured, and every attention will be paid to the Press generally."* On January 2nd, I799, he writes : "Most secret. Already we feel the want and, indeed, the absolute necessity of the primum mobile. We cannot give that authority to the Press which is requisite. We have good materials among the young barristers, but we cannot expect them to waste their time and to starve into the bargain. I know the difficulties, and shall respect them as much as possible in the extent of our expenditure, but, notwithstanding every difficulty, I cannot help most earnestly requesting to receive $f, 5,000$ in bank notes by the first messenger" (Cornwallis Correspondence, III., p. 27). I give in full the reply to this communication : "Private and most secret. Whitehall, January $7^{\text {th }}$, I 799, 20 minutes past 5. My dear Lord,-Immediately on receipt of your Lordship's letter of the 2nd instant, I waited on the Duke of Portland at Burlington House, who, without loss of time, wrote both to Mr. Pitt and Lord Grenville on that part of the letter which seemed to press the most, and I have the satisfaction to be able to inform your Lordship that a messenger will be sent off from hence in the course of to-morrow with the remittance particularly required for the present moment, and that the Duke of Portland has every reason to hope

* Cornwallis Correspondence., II., p. 444. 
that means will soon be found of placing a larger sum at the Lord Lieutenant's disposal. Believe me, etc., William Wickham." 'The editor of the Cornwallis Correspondence states that the numbers of the notes, amounting to $f_{0}, 000$, are still preserved in the State Paper Office. A few days later Castlereagh acknowledged the reply: " The contents of the messenger's despatches are very interesting; arrangements with a view to further communications of the same nature will be highly advantageous, and the Duke of Portland may depend on their being carefully applied " (Cornwallis Correspondence, III., P. 34 ; Castlereagh Correspondence, II., p. 82).

The public discussion which was invited on the subject of the Union took place in the interval between November, 1798, and the meeting of the Irish Parliament on January 22nd, I799. The pamphlet of Mr. Edward Cooke, the Irish Under Secretary, entitled Arguments for and against a Union between Great Britain and Ireland, is the ablest exposition of the policy of the Government, and furnished most of the advocates of the Union with the substance of their speeches. The subject at once absorbed public attention almost to the exclusion of all others, and it is stated that before the end of 1798 no less than twentyfour pamphlets relating to it had already appeared, of which the ablest was a pamphlet entitled Cease your Funning, written in reply to that of Mr. Cooke, by Charles Kendal Bushe, afterwards Lord Chief Justice of Ireland. To the historian, however, the notes of Mr. Cooke " in favour of the Union," preserved among Lord Castlereagh's papers, written for the private use of Ministers by this gentleman, who was actively employed in the direct bribery of Members of Parliament, supply one at least of the points in favour of the Union which could 
not be brought before the public. "Will the Union," he asks, "render Ireland quiet? Who can judge for the future? Yet, although we cannot command futurity, we are to act as if futurity were in our power. We must argue from moral causes to moral effects. If, then, we are in a disadvantageous position, we must, of course, look to the causes which have brought us into that situation. What are they ?" He then enumerates six causes, placing second on the list "The general prosperity of the country, which has produced great activity and energy" (Castlereagh Correspondence, II., p. 45). Commenting on this passage in the year 1849 , when it was for the first time revealed to the public, Lord Cloncurry thus writes: "When the contrivers of the Legislative Union in 1799 avowed to each other in their most secret communications the great object of their work to be a stoppage of the growing prosperity of Ireland, they probably did not dream of so complete an attainment of that end as their successors have achieved in 1849 . Their high vaulting ambition has o'erleaped its selle" (Personal Recollections of Valentine, Lord Cloncurry, pp. $471-472)$.

In this month of November, 1798, Lord Castlereagh, who had been acting for Mr. Pelham as Chief Secretary owing to his absence in England from ill-health, was appointed, on Mr. Pelham's resignation, as his successor. The appointment, which encountered much opposition, chiefly on the part of the King, who clung to the old rule that this office should never be held by an Irishman, was strongly supported by Lord Cornwallis, who saw, as appears from his own words, in Lord Castlereagh one specially fitted for the work of procuring votes and influence for the Union. In a letter to the Duke of 
Portland on November 20th, 1798, Lord Cornwallis writes: “Lord Castlereagh's appointment gave me great satisfaction, and although I admit the propriety of the general rule, yet he is so unlike an Irishman, I think he has a just claim to an exception in his favour. When I, therefore, found a man in actual execution of the duty, possessed of all the necessary qualifications, with a perfect knowledge of the characters and connections of the principal personages in this country, I felt it to be my duty, at this very important moment, to press his appointment in the very strongest terms" (Cornwallis Correspondence, II., p. 439).

Before the meeting of Parliament there were some notable indications of public opinion, in addition to pamphlets and newspaper articles, on the question of the Union. On December 9 th, at a meeting of the Irish Bar, a resolution was carried by 166 to 32 condemning the Union as an innovation which it would be highly dangerous and improper to propose at the present juncture. "Your Grace," writes Lord Cornwallis to the Duke of Portland in a "secret and confidential" letter on the 15 th December, 1798 , "will probably have seen in the papers an account of the violence which disgraced the meeting of the barristers, and of the miserable figure which the friends of the Union made in the division." "The editor of the Cornwallis Correspondence informs us that "the Union was violently" opposed by almost all the barristers except such as those who held office under the Crown or were in expectation of preferment. Of the thirty-two who composed the minority at this meeting, all but five had, before the close of 1803 , obtained their reward. Among them were numbered five Judges, sixteen County Court Judges, 
two Officers in . Chancery, three Commissioners of Bankrupts, and one Commissioner of the Board of Compensation (Cornwallis Correspondence, III., p. 18). The opposition of the Bar was strenuously supported. A large and representative meeting of the bankers and merchants of all religious opinions was held in Dublin on December 18 th, and resolutions were unanimously passed acknowledging the great increase of Irish commerce and prosperity since 1782 , expressing the strongest sentiments of loyalty to the King and the Constitution, but at the same time condemning in emphatic terms as highly dangerous and impolitic any attempt to deprive the Irish people of their Parliament. "If opinions," writes Mr. Lecky, " were to be weighed as well as counted, the significance of this meeting could hardly be overestimated." (See Lecky's History of England in the Eighteenth Century, VIII, pp. 323-324.)

It was considered a great triumph when some of the leading supporters of the Union induced the chief Orange lodges both in Dublin and the North to come to an agreement that they would not, as a society, take any part in the discussion, but would leave each Orangeman in his individual capacity free to adopt what line he pleased (Lecky's History of England in the Eighteenth Century, VIII., p. 323).

The attitude of the Catholics is thus described by Lord Cornwallis in the beginning of January, 1799: " Certain it is that they now hold off. . . . What line of conduct they will ultimately adopt, when decidedly convinced that the measure will be persevered in on Protestant principles, I am incapable of judging. I will endeavour to give them the most favourable impression without holding out to them hopes of any relaxation 
on the part of the Government, and shall leave no effort untried to prevent an opposition to the Union being made the measure of that party" (Cornwallis Correspondence, III., pp. 28-29). It must have been clear to Lord Cornwallis and the British Cabinet that the general sense of the Irish people was opposed to the project of the Union. As, however, we have so often seen in the record of the Irish Parliament, owing to its constitution, that Parliament was frequently far from being a reflection of the wants and wishes of the people, and was reduced by the corrupt influence of the owners of the nomination boroughs to the position of a subservient drudge of the British Cabinet. The Government relied on the borough interest for carrying the measure through Parliament, and on the fear of dismissal from office as a penalty for voting against it. On the 2ist December, 1798, a few days after the manifestations of public opinion averse to the measure, to which attention had been directed, the Duke of Portland wrote to Lord Cornwallis authorising him formally to assure all persons who had political influence that the King's Government was determined to press on the Union " as essential to the well-being of both countries, and particularly to the security and peace of Ireland as dependent on its connection with Great Britain," that they would support it with their utmost power, that even in the event of present "failure" it would be " renewed on every occasion until it succeeds, and that the conduct of individuals upon the subject will be considered as the test of their disposition to support the King's Government " (Cornwallis Correspondence, III., p. 20 ; Lecky's History of England in the Eighteenth Century, VIII., p. 336).

Three days later the Duke of Portland, anxious to 
make his meaning plainer, writes to Lord Cornwallis thus: "I desire to assure your Excellency, in the most explicit and unqualified terms, that every one of the King's servants, as well as myself, will consider themselves indissolubly obliged to use their best endeavours to fulfil whatever engagements your Excellency may find it necessary or deem it expedient to enter into with a view of accomplishing the Union of Great Britain and Ireland " (Castlereagh Correspondence, II., p. 6o). There was, however, a difficulty in the way of dismissals from office, which Lord Cornwallis explains with amusing naïvete to the Duke of Portland in a secret letter on January IIth, I Z99. "I have already," he says, "felt it a question of considerable delicacy to decide in what instances and at what period it was expedient to remove from office persons who have taken a decided tone against the measure, or who, without acting publicly, hold a language equally prejudicial to its success and equally inconsistent with their connection with the Government. In the instance of $\mathrm{Mr}$. J. C. Beresford, whose conduct has been very hostile at many of the Dublin meetings, the difficulty has been peculiarly felt. With a view of impressing our friends with the idea of our being in earnest, his dismissal seemed desirable ; on the other hand, as we profess to encourage discussion, and neither to precipitate Parliament nor the country in the decision, much less to force it against public sentiment, there seemed an objection to a very early exercise of Ministerial authority on the inferior servants of the Crown." The letter goes on to state that Lord Cornwallis thought it expedient to proceed in the first instance with the Chancellor of the Exchequer, Sir John Parnell (Cornwallis Correspondence, III., p. 35). 
Sir John Parnell was dismissed on January 16 th, and $\mathcal{}$ replaced by Isaac Corry, a staunch Unionist. The dismissal of the Prime Serjeant, James Fitzgerald, imme-

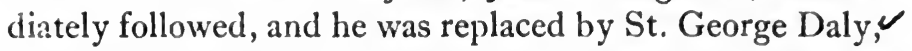
one of the minority who had supported the Union at the Bar debate. The holder of the office of Prime Serjeant, unknown in England, in Ireland took precedence of the Attorney-General and the Solicitor-General, and the emoluments were very great. St. George Daly was incompetent to discharge the duties of the office, never having been in any considerable practice at the Bar. It was indeed wittily observed that the Union was the first brief from which he had spoken. A meeting of the Bar was called to express to Mr. Fitzgerald the thanks of his profession for his disinterested patriotism. The Bar also determined that precedence in the Courts should be continued to Mr. Fitzgerald. To this, however, Lord Clare, as Lord Chancellor, would not accede. George Knox, one of the Commissioners of Revenue, resigned his office; John Claudius Beresford shortly afterwards took a similar course. The fate of Sir John Parnell and of Mr. Fitzgerald was, of course, a clear intimation of what the other place-holders had to expect in opposing the Government. Mr. Sheridan, a few days after these incidents, asked in the British House of Commons on February 7 th, 1799, "Did the right hon. gentleman (Mr. Pitt) not know that there were (out of 300 members) II 6 placemen in the (Irish) House of Commons, and that, having made two great examples by dismissing the Chancellor of the Exchequer and the Prime Serjeant, the others would be sure to remain staunch and true out of fear ?"

On the day before the measure of Union was first 
proposed to the Irish Parliament, Lord Cornwallis, in a letter of the 21st January, 1799 , to his life-long friend, General Ross, thus unbosoms himself and laments his position and the course of conduct repellent to anyone with the feelings of a man of honour, to which, as he conceives, his public duty coerces him. His words, if they stood alone, would furnish abundant evidence of the baseness of the methods by which the Irish Parliament was destroyed : "Here I am embarked in all my troubles and employed in a business which is ill-suited to my taste, and for which I am afraid I am not qualified. We think ourselves tolerably strong as to numbers, but so little confidence is to be placed in professions, and people change their opinions here with so little ceremony, that no man who knows them can feel his mind quite at ease on that subject. The demands of our friends rise in proportion to the appearance of strength on the other side, and you, who know how I detest a job, will be sensible of the difficulties which I must often have to keep my temper, but still the object is great, and perhaps the salvation of the British Empire may depend upon it. I shall, therefore, as much as possible, overcome my detestation of the work in which I am engaged, and march steadily on to my point" (Cornwallis Correspondence, III., pp. 39-40). 


\section{XXV.}

\section{DEFEAT OF 'THE PROPOSAL OF THE UNION \\ IN THE IRISH PARLIAMENT, 1799.}

I HAVE endeavoured to describe the various contrivances of extraordinary ingenuity and cynical wickedness adopted to prepare the Irish Parliament and the Irish people for the proposal of the destruction of the legislative independence of the country. I now desire to trace the stages in the processes of force, fraud, and metallic corruption by which the abolition of the Irish Constitution was effected, from the meeting of the Irish Parliament on January 22nd, 1799, till August Ist, 1800, when the Act of Legislative Union received the Royal Assent. The speech of Lord Cornwallis at the opening of the Parliamentary Session which produced the debate in the House of Commons on the Union, which lasted for two and twenty hours, did not expressly mention that absorbing topic. It simply stated "that the unremitting industry with which our enemies persevere in their avowed design of endeavouring to effect a separation of this country from Great Britain must have engaged your particular attention, and His Majesty commands me to express his anxious hope that this consideration, joined to the sentiments of mutual affection 
and common interest, may dispose the Parliaments in both kingdoms to provide the most effectual means of maintaining and improving a connection essential to their common security, and of consolidating, as far as possible, into one firm and lasting fabric the strength, power, and resources of the British Empire." The address to that $\checkmark$ speech was moved by Lord Tyrone, the eldest son of the Marquis of Waterford, who delivered a speech written by his friends, which he concealed in the crown of his hat, taking frequent glances at it to refresh his memory. The address was seconded by Mr. Robert Fitzgerald, a country gentleman, in a short and feeble speech. He had been won over to the cause of the Union by Lord Cornwallis's promise that, if the measure were carried, a royal dockyard would be built near Cork, which would double the value of his estates (Barrington, Rise and Fall of the Irish Nation, pp. 234-235). An amendment to the address, which was opposed in limine toto by Sir John Parnell, was moved and seconded by Mr. George Ponsonby and Sir Lawrence Parsons, which pledged the House of Commons to enter into a consideration of what measures might best strengthen the Empire, " maintaining, however, the undoubted birthright of the people of Ireland to have a resident and independent Legislature such as it was recognised by the British Legislature in $17^{8} 2$, and was finally settled at the adjustment of all difficulties between the two countries." The arguments for and against the Union were very brilliantly set forth and expounded by the various speakers. The Opposition confidently asserted that the feeling of the country was. overwhelmingly against the destruction of the Irish Parliament, while Mr. Plunket boldly declared that " within these last six weeks a system of black corruption 
had been carried on within the walls of Dublin Castle which would disgrace the annals of the worst period of the history of either country." It was stated in the House of Commons, without fear of contradiction, that one gentleman, a Member of that assembly, had received his commission as colonel the day before the division. An incident occurred during that debate on which, if it stood alone, the charge of shameless and avowed corruption as the basis of the Union could be abundantly sustained. "One Member," says Mr. Lecky, " near the close of the debate, after an ambiguous and hesitating speech, announced his intention of voting for the amendment of the Opposition. Shortly before the division he arose again to say that he was convinced that he had been mistaken and would now vote for the Ministers. Barrington states that it was well known in the House that in the interval he had received from Lord Castlereagh the promise of the peerage he afterwards obtained " (Lecky's History of England in the Eighteenth Century, VIII., p. 343). The person whose conduct is thus described was Mr. Frederick Trench, of Woodlawn, the first Lord Ashtown, whose name, with the date of the creation of his peerage, December 27 th, 1800 , appears in the list of the peerages conferred for " services" in connection with the Union, which is preserved in the Cornwallis correspondence. Sir Jonah Barrington, who was a member of the House of Commons at the time, spoke in this debate and took part in the division. He thus describes the conduct of Mr. Trench, of which he was an eye-witness : "It was suggested," he writes, "that Mr. Trench had been long in negotiation with Lord Castlereagh, but it did not, in the early part of that night, appear to have been brought to any conclusion; his con- 
ditions were supposed to be too extravagant. Mr. Trench, after some preliminary observations, declared in a speech that he would vote against the Ministers. This appeared a stunning blow to Mr. Cooke, who had been previously in conversation with $\mathrm{Mr}$. Trench. He was immediately observed sidling from his seat nearer to Lord Castlereagh. They whispered earnestly, and, as if restless and undecided, they both looked wistfully towards Mr. Trench. At length the matter seemed to be determined on. Mr. Cooke retired to a back seat and was obviously endeavouring to count the House, probably to guess if they could that night dispense with Mr. Trench's services. He returned to Castlereagh. They whispered again, looked most affectionately at Mr. Trench, who seemed unconscious that he was the subject of their consideration. But there was no time to lose-the question was approaching. All shame was banished. They decided on the terms, and a significant and certain glance, obvious to everybody, convinced Mr. Trench that his conditions were agreed to. Mr. Cooke then went and sat down by his side. An earnest but very short conversation then took place; a parting smile completely told the House that Mr. Trench was that moment satisfied. These surmises were soon verified. Mr. Cooke went back to Lord Castlereagh-a congratulatory nod announced his satisfaction. ... This change of ideas, and the majority of one, to which it contributed, were probably the remote causes of persevering in a Union."

Sir Jonah Barrington refers to the fact that the amendment to the Address was rejected by a majority of one, being supported by 105 votes and opposed by 106 . If $\mathrm{Mr}$. Trench had voted as he originally intended, there would have been a majority of one for the amendment. 
If he had abstained from voting, there would have been an equality of votes, and the amendment would have been carried by the casting vote of the Speaker. The original Address was then carried by 107 to 105 . When we remember the composition of the Irish House of Commons, the number of placemen who were Members of that body, and the number of Members who abstained from voting, these votes were equivalent to a severe defeat on a cardinal matter of Government policy. In the House of Lords the Address to the 'Throne was carried by 52 votes to 16 , including one proxy.

When the report of the Address came before the House of Commons on the afternoon of January $23 \mathrm{rd}$, Mr. Ponsonby moved an amendment to omit the clause relating to the intended Union, which was carried after a prolonged and angry debate, in which no fewer than 60 members participated, by 6 votes-III to 105. In the division the Opposition withdrew, according to practice, from the Chamber of the House to the Court of Requests, and were counted as they re-entered the House, in which the supporters of the Government had remained, and had been counted, their number being ascertained. As the anti-Unionists walked deliberately in one by one to be counted, when their number exceeded the number of the adherents of the Government, their exultation was unbounded, and the announcement of the numbers from the Chair was the occasion of a scene of almost unparalleled enthusiasm. Mr. Ponsonby wished to push still further his great triumph by proposing a substantive resolution pledging the House for ever " to maintain the undoubted birthright of Irishmen by preserving an independent Parliament of Lords and Commons resident in this kingdom as stated, and approved by His Majesty and 
the British Parliament in 1782." Just as the Speaker was about to put the question finally, Mr. Fortescue said that he was averse to the Union, and had given his decided vote against it, but he did not wish to bind himself for ever ; possible circurnstances might hereafter occur which might render that measure expedient for the Empire, and he did not approve of any determination which for ever closed the doors against any possibility of future discussion. Several country gentlemen expressed agreement with Mr. Fortescue in his view. Mir. Ponsonby, who saw that these seceders would give a majority to the Government, and that a division could not be risked, begged leave, which was given, to withdraw his motion-a proceeding which was acutely characterised by a cynical Member as " a retreat after victory." The Address, without the passage relating to the Union, was agreed to by the House and presented to the Lord Lieutenant, and the House adjourned for a week.

The joy in Dublin over the defeat of the Union project was highly demonstrative. On the Speaker's coming out of Parliament House, the horses were taken from his carriage and he was drawn in triumph through the streets by the people, who conceived the whimsical idea of tacking the Lord Chancellor to the coach and (as a captive General in a Roman triumph) forcing him to tug at the chariot of his conqueror. " $\mathrm{Had}$ it been effected," writes Sir Jonah Barrington, " it would have been a signal aneciote, and would, at least, have immortalized the classic genius of the Irish" (Rise and Fall of the Irish Nation, page 255). The populace pursued the Lord Chancellor for this extiaordinary purpose, who escaped with great difficulty. Orders were given for a general illumination; even the General Post Office, 
though a Goiernment establishment, was illuminated. 'The windows of those who refused to illuminate were broken, and among them those of the Lord Chancellor. His servants fired on the mob, and he expressed his hope to $i$,ord Auckland that they had wounded some of then!n. Prominent Members who had voted for the Government ivere molested in the street. "A view of these enemics," writes Sir Jonah Barrington, " as they came skulking f:on. behind the corridors, aroused the mob to no very tranquil temperature. Some members had to try their speed, and others their intrepidity " (Rise and Fall of the Irish Nation p. 256). Men shook their neighbours heartily by the hand, as if the Ministers' defeat were an event of individual good fortune. The character of the composition of the division was very remarkable. Lord Castlereagh acknowledged that "what seemed to operate most unfavourably was the warmth of the country gentlemen, who spoke in great numbers and with much effect against the question." "The Opposition," he said, " exclusive of the Speaker, Sir J. Parnell, and the Ponsonbys, is composed of country gentlemen. No fewer than thirty-four county Members voted against the Government, while only seventeen supported them " (Lecky's History of England in the Eighteenth Century, VIII., p. 348). Of the eighty-four absent Members from the division, Sir Jonah Barrington tells us that twentyfour were kept away by absolute necessity, and of the residue, there can be no doubt they were not friends to the Union, for this plain reason, that the Government had the power of enforcing the attendance of absent members and the Opposition had no power; they had none but voluntary supporters, of whom Lord Castlereagh was enabled to seduce 43 during the prorogation, 
and by that acquisition outvoted the anti-Unionists on the 5 th February, 1800 (Rise and Fall of the Irish Nation, pp. 252-253).

Mr. Sheridan, in the British House of Commons, thus disposed of Mr. Pitt's assertion that an equal proportion of the Irish House of Commons was favourable to the Union: "If he (Mr. Pitt) would but look of what the division against the Union in the Irish House of Commons was composed, he would discover that it contained almost all the country gentlemen, while, if he examined who composed that on the other side of the question, they would almost all be found to be under the influence of the Crown; if, besides this, the dismissals which had taken place, in spite of the fair character of those who were removed-thus unjustly removed from office-it was a shame to speak of anything like an equality between those who opposed and those who supported the Union (Parliamentary Debates, VII.,p.668). The vexation of the promoters of the Union in Ireland at the defeat of the proposal in the House of Commons was very great. Clare spoke of Ponsonby as "a malignant knave," "but," he said, " allowing for the villainy and treachery which might have been expected, I always understood there was a certain majority of thirty in support of the Government." "Will it not be fair for me," writes Cooke, "to ask that I may be allowed to change my situation into England? I am disgusted here" (Lecky's History of England in the Eighteenth Century, VIII., p. 349).

"I have now only," writes Lord Cornwallis to the Duke of Portland, " to express my sincere regret to your Grace that the prejudices prevailing among the Members of the House of Commons, countenanced and encouraged as they have been by the Speaker and Sir John Parnell, 
are injinitely too strung to afford me any prospect of bringing this measure with any chance of success into discussion in the course of the present Session " (Cornwallis Correspondence, III., p. 45). Mr. Pitt likewise was much disappointed, and desirous, if the penalties of dismissal could be inflicted without ultimate injury to the cause of the Union, to dismiss the placemen who voted against the Union proposal in the Irish House of Commons, and more especially to make the Speaker feel the sense of his displeasure. His words in a private letter to Lord Cornwallis on the 26th January, 1799, written immediately on hearing of the division in the Irish House of Commons on January 23rd, are in glaring contrast with his assertion in the English House of Commons on January 3 Ist, that it was " within the full right and competence of the Irish Parliament to accept or reject a Union." Mr. Pitt thus takes Lord Cornwallis into his confidence in his choice of making the persons who opposed his Irish policy victims. "It seems very desirable," he writes, "if Government is strong enough to do it without too much immediate hazard, to mark by dismissal the sense entertained of the conduct of those persons in office who opposed. In particular it strikes me as essential not to make an exception to this line in the instance of the Speaker's son. No Government can stand on a safe and respectable ground which does not show that it feels itself independent of him. With respect to persons of less note, or those who have been only neutral, more lenity may, perhaps, be advisable. On the precise extent of the line, however, your Lordship can alone judge on the spot, but I thought you would like to know from me directly the best view I can form of the subject" (Cormwallis Correspondence, III., p. 57). 
The measure having been ostensibly submitted to the Irisi House of Commons for discussion, it seemed inconsistent to dismiss those who lad given a candid opinion against it. In process of time, as we shall see, the moment came for Lord Castlereagh to announce unequivocally that the Irish Ministry were engaged in a contest in which they had " the whole weight of the British Government at their back."

Lord Cornwallis, it is quite evident, acknowledged the defeat of the Government in the Irish House of Commons on a subject of primary importance. In accorcance with the practice of the Constitution, as we understand it, the duty of a Ministry under these circumstances would be either to resign or to appeal by a dissolution from the decision of Parliament to the decision of the country. The Irish Administration, however, looking for support, not to Ireland, but to England, recognised no such principle of action. They knew an easier plan, which was to proceed with redoubled energy to corrupt and degrade the Parliament of Ireland with a view to its eventual extinction. This episode affords a very striking illustration of the cardinal defect in the Irish Constitution to which I have so frequently directed attention in these pages. Ireland never had an Irish Cabinet responsitle to the Irish Parliament, and through that Parliament to the Irish people. With such a Cabinet the Irish Parliament, unreformed though it was, and with a Roman Catholic population unemancipated, would still have preserved the liberties of its country. If Ireland, notwithstanding all those disadvantages, had possessed the blessings of a responsible Government, the Union could never have been carried.

Mr. Pitt, who at first was resolved that the Union, if 
carried, should be associated with a measure of Cathoiic $\| v$ Emancipation, was inclined, as we have seen, by the representations of Lord Chancellor Clare, to promote a measure of Union unaccompanied with Catholic Emancipation. Mr. Pitt, whose proposal of a Union was defeated in the Irish House of Commons, had at first, by a private dispatch to Lord Cornwallis, desired that the meastre should not be pressed unless he could be certain of a majority of fifty. "The Lord Chancellor," writes Sir Jonah Barrington, " on learning the import of that dispatch, expostulated in the strongest terms at so pusillanimous a decision. His Lordship never knew the meaning of the word ' moderation ' in any public pursuit, and he cared not whether the Union was carried by a majority of one or one hundred. The original dispatch I saw and read; it was brought from Mr. Cooke's office secretly, and shown to me for a particular purpose, and completely deceived me, but I could not obtain possession of it. I afterwards ciscovered that it had not been replaced in the office. It was subscribed by Mir. Pitt himself, and the name of Mr. Banks occurred more than once in it; it did not compliment him. I have reason to believe that that dispatch, with some important papers, was afterwards accidentally dropped in College Green, and found by Dr. Kearney, then Provost of Dublin University (subsequently Bishop of Ossory, an anti-Unionist). He told me he had found such papers, and promised to show them to me at a future day, when the question was decided, but never did" (Rise and Fall of the Iris?. Nation, pp. 263-264). Lord Clare's furious condemnation of the Lord Lieuteoant on having contributed by his conduct in releasing dangerous rebels and repressing Orange zeal to the defeat of the Union, may have 
been inspired by a desire of protecting himself from censure in pressing forward the question of the Union, with a result so disastrous. Mr. Pitt divested himself of his former scruples against the carrying of a Union through the Irish Parliament otherwise than by a decisive majority. His Cabinet had determined that the measure would not be abandoned whatever the result of the vote of the Irish House of Commons might be. It was the unanimous opinion of Ministers. Portland wrote that nothing that had happened should make any change in their intentions or plans. "I am authorised to assure you," he wrote, " that whatever may be the fate of the Address, our determination will remain unaltered and our exertions unabated, and that, though discretion and good policy may require that the measure should be suspended by you during this Session, I am to desire that you will take care that it shall be understood that it neither is nor ever will be abandoned, and that the support of it will be considered as a necessary and indispensable test on the part of the Irish to their connection with this country" (Castlereagh Correspondence, II., p. I37).

On January 22nd, the same day on which the Session of the Irish Parliament was opened, a King's message had been sent down to the British Parliament in similar terms to the Viceregal speech, recommending a complete and final adjustment of the relations between Great Britain and Ireland. Sheridan moved an amendment, but found no supporters, and, after speeches by Canning and Pitt, the amendment was negatived without a division. On January 3 Ist, after the news had arrived of the refusal of the Irish House of Commons to entertain a proposal in relation to a Union, Pitt rose in the British House of 
Commons to move resolutions for a Union, despite the attitude of the Irish House-of-Commons thereto. In 1797 it will be remembered that Pitt deprecated the proposal of Mr. Fox to consider the state of Ireland on the ground that the Irish Parliament was an independent legislature, and that, accordingly, the affairs of that country should not be discussed in the British Parliament, as such discussion would be an unwarrantable interference with matters within the purview and jurisdiction of the Irish Parliament, and an attack on its independence. Mr. Pitt, however, had now no scruples in urging on the acceptance of the British Parliament a series of resolutions for the destruction of an Irish Parliament by the method of a Legislative Union between Great Britain and Ireland. This speech, of which it is said no fewer than 10,000 copies were circulated at the public expense, is a comprehensive statement of the case for the Union, and is of interest at the present time as replete with ludicrous miscalculations as to the effect which a measure of Union would produce on the conditions both of Great Britain and Ireland. The sincerity of some of Mr. Pitt's assertions may perhaps be gauged by his assertion that the scheme which he was proposing, with the full knowledge of its rejection by the Irish House of Commons, could only come into operation by its ultimate adoption by the Irish Parliament, and that he was confident that all that was necessary to secure that ultimate adoption was " that it should be stated distinctly, temperately, and fully, and that it should be left to the dispassionate and sober judgment of the Parliament of Ireland "- the Parliament of Ireland whose members at that very moment he was conspiring with the Irish Government to terrorise, to coerce, to penalise for their votes, and to bribe by 
honours and by coarse metallic corruption. The resolutions proposed by Pitt were for nearly three weeks under discussion in the British House of Commons, where they were subjected to the strictures of Sheridan, supported by a very few friends, notably Dr. Laurence, the intimate friend of Edmund Burke, and the repository of his most confidential political ideas, and by Mr. Grey, afterwards as Earl Grey, the Prime Minister of the Reform epoch. The minority in this hopeless fight, which was sustained with supreme political ability and courage, was never above iwenty-four. In the British House of Commons the resolutions in their final form

$\checkmark /$ were carried by 149 votes to 24 , and in the British House of Lords without a division. The proceedings in this connection in the British Parliament are chiefly of interest as conclusive evidence of the fixed determination that the destruction of the Irish Parliament should be accomplished with utter disregard to the wishes of the Irish people. In a letter written by Lord Cornwallis to the Duke of Portland, to be laid before the Cabinet two days after the defeat of the Union proposal in the Irish House of Commons, which Mr. Pitt must have seen and considered before his speech, the Lord Lieutenant says : "The late experiment has shown the impossibility of carrying a measure which is contrary to the private interests of those who are to decide upon it, and which is not supported by the voice of the country at large" (Cornwallis Correspondence, III., p. 52). Mr. Pitt, with this knowledge of the feeling of Ireland on the subject of a Union, described it in the Housc of Commons as a Union "by free consent and on just and equal terms."

The Irish Parliament was prorogued on June Ist, 1799. The proceedings of that assembly, subsequent to the 
rejection of the Union proposal, were marked by its wonted subscrviency to the Government. The disturbed state of the country was made the occasion of the passing of Indemnity Acts, and of a Coercion Act of extraordinary severity, placing Ireland, at the will of the Lord Lieutenant, formally and legally under military law - an Act which seems to have been part and parcel of the system of terrorism established in Ireland for the purpose of passing the Union. Past transgressions of the law which had taken place since October 6th, 1798, for the purpose of suppressing the rebellion, preserving the public peace, and for the safety of the State, were condoned by the very comprehensive Indemnity Act which received the Royal Assent on March 25th, 1799 (39 Geo. III., c. 3), (Lecky's History of England in the Eighteenth Century, VIII., p. 320). The Coercion Act, 1799 (39 Geo. III., c. II), investing the Lord Lieutenant with the powers of a despotic ruler, if not actually passed for the purpose of prolonging a reign of terror with the object of passing the Union, was administered for that purpose and in that spirit. Lord Cornwallis, writing on December 26th, 1798, says : "I am strongly pressed to use the same coercive measures which so totally failed last year, but I cannot be brought to think that flogging and free quarters will ever prove good opiates " (Cornwallis Correspondence, III., p. 24). He was, however, prevailed on to support the legislation embodied in the Coercion Act of I799. " The preamble of this Statute noticed that Lord Camden, on March 30 th, 1798, had, with the advice of the Privy Council, directed the military commanders in Ireland to employ all their forces to suppress rebellion ; that the order of May 24th, commanding them to punish by death or otherwise according to martial 
law all persons assisting in the rebellion, had received the approbation of both Houses of Parliament; that although this measure had proved so far efficacious as to permit the course of common law partially to take place, very considerable parts of the kingdom were still desolated by a rebellion which took the form of acts of savage violence and outrage, and rendered the ordinary course of justice impossible, and that many persons who had been guilty of the worst acts during the rebellion, and had been taken by His Majesty's forces, had availed themselves of the partial restoration of the ordinary course of the common law to evade the punishment of their crimes. The Bill accordingly empowered the Lord Lieutenant, as long as the rebellion continued, and notwithstanding the opening of the ordinary Courts of Justice, to authorise the punishment, by death or otherwise, according to martial law, of all persons assisting in the rebellion or maliciously attacking the persons or properties of the King's loyal subjects in furtherance of it ; the detention of all persons suspected of such crimes and their summary trial by court martial. No act done in pursuance of such an order could be questioned, impeded, or punished by the courts of common law, and no person duly detained under the powers created by this Act could be released by a writ of Habeas Corpus " (Lecky's History of England in the Eighteenth Century, VIII., pp. 370-37I).

The method in which the Coercion Act was administered can be told in the words of Lord Cornwallis himself, who was accused of lenity, and to whose lenity in dealing with rebels the blame of the defeat of the Union measure was imputed. "You write," he says to his bosom friend, General Ross, on April $15^{\text {th, }} 1799$, " as if you really believed there was any foundation for all 
the lies and nonsensical clamour about my lenity. On my arrival in this country I put a stop to the burning of houses and murder of the inhabitants by yeomen or any other persons who delighted in that amusement, to the flogging for the purpose of extorting confessions, and to the free quarters which comprehended universal rape and robbery throughout the whole country" (Cornwallis Correspondence, III., p. 89). We are given some glimpses by the Lord Lieutenant himself of the operation of the Coercion Act. In a letter written to Lord Castlereagh, dated September 26th, 1799, he thus speaks of the state of the country: "The same wretched business of courts martial, hanging, transporting, etc., attended by all the dismal scenes of wives, sisters, fathers, kneeling and crying, is going on as usual, and holds out a pleasant prospect for a man of my feelings " (Castlereagh Correspondence, II., p. 406). On November I6th, 1799, Lord Cornwallis writes to General Ross: "The greatest difficulty which I experience is to control the violence of our loyal friends, who would, if I did not keep the strictest hand upon them, convert the system of martial law (which, God knows, is of itself bad enough) into a more violent and intolerable tyranny than that of Robespierre. The vilest informers are hunted out from the prisons to attack by the most bare-faced perjury the lives of all who are suspected of being or of having been disaffected, and, indeed, every Roman Catholic of influence is in great danger. You will have seen by the Addresses (relative to the Union) both in the North and South, that my attempts to moderate that violence and cruelty which have once driven, and which, if tolerated, must again soon drive, this wretched country into rebellion, is not reprobated by the voice of the country, although it has 
appeared culpable in the eyes of the absentees" (Cornwallis Correspondence, III., p. 145).

It is interesting to note that Lord Cornwallis, whose character can be most favourably contrasted with other promoters of the Union, both in England and Ireland, refuses the shocking invitation of the British Cabinet, made through the Duke of Portland, to place 5,000 Russian troops at his disposal. "If," he replies on October i 4 th, I799, " the Russians were to be sent over to us, their soldiers would be told they were going to a country which was in a staie of rebellion, and if any parties of them should be called upon to support some of our loyal, but, in my opinion, indiscreet, magistrates, who see no remedy for our evils but that of scouring the country and hunting down rebels (forgetful that they are creating more than they can possibly destroy), these troops, unacquainted with our language and with the nature of our Government, would give a loose to their natural ferocity, and a scene of indiscriminate plunder and murder must ensue." $\mathrm{He}$ also stated that the presence of these troops would countenance the suggestion "that the Union was to be forced on the kingdom by the terror and the bayonets of barbarians" (Cornwallis Correspondence, III., pp. 137-138). "It was maintained," writes Mir. Lecky, "with much reason, that a time when martial law was in force was not one for passing through a vast constitutional change unasked for by the country, and violently opposed by a great section of the people" (Lecky's History of England in the Eighteenth Century, VIII., p. 372).

On March 7 th a series of resolutions brought in by Mr. Dobbs in favour of Parliamentary Reform, Catholic Emancipation, the commutation of tithes and other 
propular questions, was met by the previous question, and as Mr. Dobbs appears to have acted without any cuncert, the previous question was carried by 68 to $\mathbf{I}$. Lord Corry moved that the House should at once resolve itseif into a Committee on the state of the nation, the mover announcing his intention to move an address to the King representing a separate independent Parliament to be essential to the interest of Ireland. The motion, which was opposed by Lord Castlereagh on the ground that there was no present intention to press the Union, was defeated by 123 votes to 103. A Regency Bill, moved by Mr. James Fitzgerald, the dismissed Prime Serjeant, enacting that the person who was ipso facio Regent of England should be always with the same powers de jure Regent of Ireland, passed successfully through its earlier stages and through the Committee, but in the report Castlereagh moved its rejection, and it was ultimately postponed till the Session had closed. This Bill, which the Government disliked as destroying part of their case for the Union, when in Committee, gave Mr. Foster, the Speaker, the opportunity of delivering, on April 12th, I799, a speech against the Union in reply to the speech of Mr. Pitt in the English House of Commons on the 3 Ist January, which took more than four hours in its delivery, and was afterwards published in a pamphlet of no less than I 3 closely printed pages. It is regarded as the yery ablest exposition of the case in all its features against the Union.

The passing of yet another Indemnity Act (39 Geo. III., c. 50), chiefly for the protection of Thomas Judkin Fitzgerald, who, as High Sheriff of Tipperary, had with his own hands flogged the peasantry to extort confession, is a curious object lesson of the ferocious temper of the 
times, and the morbid nervousness of the members of the Irish Parliament, who desired to condone any enormity, however outrageous, if perpetrated to suppress rebellion. A man named Wright, of Clonmel, was suspected of connection with the United Irishmen. On searching him a letter in the French language, of which he was a teacher, was found in his pocket. Fitzgerald ordered him to be flogged and then shot. Next day Wright was dragged to a ladder in one of the streets to undergo his sentence. He knelt down to pray, with his hat before his face. Fitzgerald snatched the hat from him, trampled it on the ground, struck Wright on the forehead with his sword, kicked him, and dragged him by the hair. $\mathrm{He}$ was then stripped naked, tied to the ladder, and fifty lashes were administered. An officer came up and asked Fitzgerald the reason of the punishment. Fitzgerald, who did not know French, handed the officer the note, who read it and found it to be perfectly harmless. $\mathrm{He}$ explained this to Fitzgerald, who ordered the flogging to proceed. One hundred more lashes were administered, leaving the man a mass of bleeding wounds. Wright was flung into prison, where he remained some six or seven days without medical assistance, in a cell with no other furniture than a straw pallet without covering (Lecky's History of England in the Eighteenth Century, pp. 25-28). Wright, notwithstanding the Indemnity Act, carried his case in March, 1799, into the Law Courts, contending that the indemnity only applied to cases in which the magistrates had acted on clear or at least serious evidence of treason, had taken all possible means of ascertaining the truth of the persons they punished, and had exercised their power with common humanity. This view was fully supported by the two 
Judges, Lord Yelverton and Mr. Justice Chamberlain. Wright was awarded $\oint_{500}$ damages; the Judges fully concurred in the verdict, expressed their belief in the perfect innocence of Wright, and added that if much larger damages had been given they would not have been excessive. It was under these circumstances that the new and fuller Indemnity Act was so drawn as to make such prosecutions as that of Fitzgerald impossible. It provided that in all cases in which sheriffs or other officers or persons were brought to trial for acts done in suppressing the rebellion, a verdict for the plaintiff should be null and void unless the jury distinctly found that it had been done maliciously and not with an intent of suppressing rebellion, preserving public peace, or promoting the safety of the State, and that even where juries did find that the act was malicious, the judge or judges who tried the case should have the power of setting such verdicts aside (Lecky's History of England in the Eighteenth Century, VIII., p. 30 ).

Lord Cornwallis, in May, 1799 , showed his ruthless determination that, so far as his power could prevail, no one opposed to the Union should be allowed to sit in the Irish House of Commons. Writing on May r6th, I799, he gives the following account of an extraordinary violation of constitutional practice; "Lieutenant-Colonel Cole recently applied to Lord Castlereagh that he might be appointed Escheator of Munster in order to vacate his seat upon his going abroad. It appeared in conversation that he had intended to have his place supplied by Mr. Balfour, who moved the resolutions against the Union at a County Louth meeting, and suggested a recurrence to first principles if that measure should be carried. Mr. Tighe had before applied for the same office 
for one of his members, with a view to sell the seat on condition that the purchaser would not support a Union. These requests appeared to me of such a nature as to render it necessary to withhold my acquiescence from him" (Cornwallis Correspondence, III., p. 97). The incident created intense irritation in the House of Commons. An address to the Crown was moved by John Claudius Beresford, requesting the grant of a pension to Colonel Cole, which, by disqualifying him from sitting in the House, would vacate his seat. The Government succeeded in defeating it by a motion for the adjournment, but their majority was only fifteen, and the Duke of Portland intimated that for the future it would be better to follow the rule adopted in England (Lecky's History of England in the Eighteenth Century, VIII., pp. 390-391).

The Lord Lieutenant, in his speech in proroguing the Irish Parliament on June Ist, did not refer to the rejection of the proposal of a Union in the Irish House of Commons, but stated that he had received the particular commands of the King to acquaint them with the addresses and resolutions of the two Houses in England in favour of a Union. He added that the King would receive the greatest satisfaction in witnessing the accomplishment of the Union, and that for his own part, if he were able to contribute in the smallest degree to the success of this great measure, he would consider the labours and anxieties of a life devoted to the public service amply repaid (Lecky's History of Engiand in the Eighteenth Century, VIII., pp. 392-393). 


\section{CHAP'TER XXVi.}

\section{MLKING A PARLIAMEN'TARY MAJORITY FOR THE UNION.}

Parimanent was prorogued on June ist, and tine new Session did not begin till January 15 th, 1800 . It will have been observed by the reader of these pages that the periods in which the Irish Parliament was not actually in Session were on several occasions utilised by the Government in procuring by corruption a Parliamentary majority. To give a single illustration: Immediately after the Session of 1768 , in which the Octennial Act had been passed, four Peers were raised a step in the Peerage, four new Peers, three Baronets, and four Privy Councillors were made as an earnest of the favours which were to be expected in supporting the Government (Lecky's History of England in the Eighteenth Century, IV., p. 385 ).

When the Parliament, which met in October, 1769 , was prorogued in December, 1769 , as a protest by the Viceroy against the rejection by the House of Commons of a Money Bill, because it did not take its rise in the House of Commons, the interval between the prorogation, on December 27 th, 1769 , and the opening of the next Session, on February 26th, 1771, was spent in open and avewed corruption with the object of making Parliament amenable to the Executive Government. The deprivation of persons, who had opposed Government, of their offices, the bestowal of peerages and steps in the peerage, the 
creation of places and pensions, and dispensation of patronage, were all exerted to the utmost to the conversion of a Government minority into a Government majority, by which an address was carried, thanking the King for continuing Lord Townshend, the Lord Lieutenant, to whom Parliament had been previously recalcitrant, in office. Lord Clare, when Attorney-General, speaking in the House of Commons in the Regency discussions, thus alluded to this episode on the $25^{\text {th }}$ February, I789 : "I recollect," he said, "Lord Townshend proroguing the Parliament, and I recollect when next they met they voted him an address of thanks, which address cost this nation half a million of money. I hope to God I shall never again see such effects from party ; I hope to God I shall never again see half a million of the people's money employed to procure an address fiom their representatives.'

In Lord Harcourt's Viceroyalty, in addition to the grant of pensions, eighteen Irish Peers were created in a single day, and seven Barons and Viscounts were at the same time raised a step in the Peerage. The terms of the bargain were well known to be an engagement to support the Govermment by their votes in the House of Lords, and by their substitutes and influence in the House of Commons (Lecky's History of England in the Eighteenth Century, IV., p. 44I).

In opposition to the Volunteer agitation in 1780 , Parliamentary influence was carefully collected and fostered by the old plan of lavishing promises of peerages, baronetcies, and pensions, and in February, 1780, Lord Buckingham, the Lord Lieutenant, wrote that he had secured his majority (Lecky's History of England in the Eighteenth Century, IV., p. 505). 
'The Regency crisis in 1789 was marked by wholesale corruption. Seven Peers were created, nine others were promoted, several Baronets were made, and $f_{13}, 000$ a year more was expended in pensions. In a speech in February, 1790, Grattan stated in Parliament that in the course of less than thirteen months fourteen new Parliamentary places and eight or nine Parliamentary pensions had been created.

I have referred with reiteration to these circumstances, with which I have previously dealt incidentally, with the object of laying stress on the fact to which Mr. Gladstone has called attention: that the corruption which characterised the Union was not an exceptional and deplorable incident in Irish Parliamentary history, but was merely the continuation, although in an aggravated form, of the methods of corruption to which the English Government uniformly resorted in dealing with the Irish Parliament.

"It seems to me," writes Mr. Lecky, " idle to dispute the essentially corrupt character of the means by which the Union was carried" (History of England in the Eighteenth Century, VIII., p. 395). Again: "There are indeed few things more discreditable in English political literature than the tone of palliation and even of eulogy that is usually adopted towards the authors of this transaction. Scarcely any element of political immorality was wanting, and the term ' honour,' if it be applied to such men as Castlereagh cr Pitt, ceases to have any real meaning in politics. Whatever may be thought of the abstract merits of the arrangement, the Union, as it was carried, was a crime of the deepest turpitude ; a crime which, by imposing with every circumstance of infamy a new form of Government on a reluctant and protesting 
nation, has vitiated the whole course of Irish opinion" (Leaders of Public Opinion in Ireland, p. 182).

Mir. Fox, in 1806 , characterisec the Union as " atrocious in its principle and abominable in its means. It was," he said, " a measure the most disgraceful to the Government of the country that was ever carried or proposed" (Morning Chronicle, February 4th, I806).

Earl Grey, speaking in the House of Lords on November 2nd, 1830 , a generation after the passing of the Union, proclaimed his conviction that there were never worse means resorted to for carrying any measure than those by which the Union was accomplished. Lord Cornwallis, the Lord Lieutenant, writing in the midst of the Union negotiations, says : "How I long to kick those whom my public duty obliges me to court." Again : "I despise and hate myself for engaging in such dirty work" (Cornwallis Correspondence, III., pp. 100-102).

When there was some opposition on the part of the Cabinet to the conferring of some of the peerages which had been promised as rewards for Union services, Lord Castlereagh, in a secret letter of June 21st, I800, gives his opinion of the methods by which the Union, of which he himself was one of the principal machinators, was carried: "It appears that the Cabinet, after having carried the measure by the force of influence, of which they were apprised in every dispatch sent from hence (Dublin) for the last eighteen months, wish to forget all this ; they turn short round and say it would be a pity to tarnish all that has been so well done by giving any such shock to the public sentiment. If they imagine they can take up popular grounds by disappointing their supporters and by disgracing the Irish Government, I think they will find themselves mistaken; it will be no 
secret what has been promised or by what means the Union has been secured. Disappointment will encourage, sot prevent, disclosure, and the only effect of such a proceeding on their part will be to add the weight of their testimony to that of the anti-Unionists in proclaiming the profligacy of the means by which this measure was accomplished" (Castlereagh Correspondence, III., pp. 330-332).

The details of these negotiations have been for the must part destroyed. The authors of the measure have purposely destroyed the evidence which would have revealed in clear light the full depth of its iniquity. Mr. Ross, the editor of the Cornwallis Corresporidence, while acknowledging his obligations to the persons who had placed materials for the work at his disposal, makes the following observations: "Many other collections have been as cordially submitted to my inspection, but it appeared upon investigation that such documents as might have thrown additional light on the history of those times, and especially of the Union, have been purposely. destroyed. For instance, after a search instituted at Welbeck by the kindness of the Duke of Portland, it was ascertained that the late Duke had burnt all his father's political papers from $\mathbf{1} 780$ to his death. In like manner the Chancellor, Lord Clare, Mr. Wickham, Mr. King, Sir Herbert Taylor, Sir Edward Littlehales, Mr. Marsden, the Knight of Kerry, and, indeed, almost all the persons officialiy concerned in carrying the Union, appear to have destroyed the whole of their papers. Mr. Marsden, by whom many of the arrangements were concluded, left a MS. book containing invaluable details, which was burnt only a few years ago by its then possessor. The destruction of so many valuable documents respecting 
important transactions cannot but be regarded as a serious loss to the political history of those times" (Cornwallis Correspondence, I., Preface, p. vi.). We discover, too, from a note by Mr. Ross, accounting for the non-appearance of a document, that " it must have been destroyed with the great mass of Lord Cornwallis' papers relating to the Union, as it cannot be found" (Cornwallis Correspondence, III., p. 197).

Marsden, who was at the time of the Union Assistant Secretary in the Law Department of Dublin Castle, and who succeeded Cooke as Under Secretary, was, with Cooke, chiefly entrusted with these negotiations. The fear and hatred felt towards Marsden by the persons of whose baseness and perfidy he was cognisant have been graphically described in a letter written by Wickham to the Lord Lieutenant, Lord Hardwicke, in 1803 , when an attack in Parliament on Marsden was in contemplation. " In writing," says Wickham, " to Mr. Yorke on the subject of the personal attack that it is intended to be made on Marsden, your Excellency will perhaps do well to call his attention to these points : (I) Marsden was the person who conducted the secret part of the Union. Ergo, the price of each Unionist, as well as the respective conduct and character of each, is well known to him. Those who figure away and vapour in so great a style in London are well known to him. They live in hourly dread of being unmasked, and they all consider him as the person who opposes their interested views and jobs by his representation of the whole truth. (2) Marsden, as a lawyer, is supposed to be the person who gives the Government the opinion which is acted on as to legal promotions. He is, therefore, supposed to be the man who has stood in the way of our filling the Bench and 
the confidential law situations under the Crown with improper persons by giving a fair and right interpretation to the Union engagements. (3) Many of the persons who make a great figure at the levée and on the benches of either House in London really dare not look Marsden in the face. I have often witnessed this, and have been diverted by it. With your Excellency and with me they have an air of uncomfortable greatness, but with him they quite shrink away." (Irish State Paper Office quoted Lecky's History of England in the Eighteenth Century, VIII., p. 407.)

Before the rejection of the proposal for a Union by the Irish Parliament in January, I799, Lord Cornwallis very clearly perceived that the Irish Parliament could not be destroyed without the lavish bribery of the borough owners and of the men who had used the Irish Parliament, by the sale of their votes to the Government, for selfish personal purposes. Two letters written by the Lord Lieutenant to the Duke of Portland before the meeting of the Irish Parliament in 1799 demonstrate the conclusion at which he had arrived. On January $5^{\text {th }}$, 1799, he writes to the Duke of Portland : " There are two classes of men in Parliament whom the disasters and sufferings of the country have but very imperfectly awakened to the necessity of a change, viz., the borough proprietors and the immediate agents of the Government " (Cornwallis Correspondence, III., p. 31).

Again, on January IIth, I799, he writes: "There certainly is a very strong disinclination to the measure in many of the borough proprietors, and a not less marked repugnance in many of the official people, particularly in those who have been longest in the habits of the current system " (Cormwallis Correspondence, III., p. 34.) The 
main power in Parliament rested with the great borough owners. It was accordingly determined to reconcile them to the scheme by honours and by compensation for the disfranchisement of the boroughs of which they were the owners, while places, pensions, titles, were to be lavishly disposed on the men who had a vested interest in what Grattan aptly designated as "the trade of Parliament." Twenty-nine Irish peerages were created, of which seven only were unconnected with the Union; 20 Irish peers were promoted, and six English peerages granted for Union services (Cornwallis Correspondence, III., p. 318). The position, moreover, of representative peer was to be enjoyed by twenty-eight members of the Irish peerage, and was to place them for life in the Imperial House of Lords, and the first representative peers were virtually nominated by the Lord Lieutenant, and they consisted exclusively of the supporters of the Union (Cornwallis Correspondence, III., pp. 286-287).

" The Irish borough owners," writes Mr. Lecky, " should be judged by no high standard, and it may be admitted to their faint credit that in some few instances their peerages did not determine their votes and their influence. In the majority of cases, however, these peerages were simply palpable open bribes intended for no other purpose than to secure a majority in the House of Commons" (History of England in the Eighteenth Century, VIII., p. 399).

Honours, however, would not in themselves compensate for the loss of interests so valuable to their owners as nomination boroughs. Two days after the defeat of the Union proposal in January, 1799 , Lord Cornwallis, in a " secret and confidential " letter to the Duke of Portland, says: "The late experiment has shown the impossi- 
bility of carrying a measure which is contrary to the private interests of those who are to decide upon it, and which is not supported by the voice of the country at large" (Cornacallis Correspondence, III., p. 323).

"I have no difficulty," writes the Duke of Portland, in another " secret and confidential " letter dated March 8th, 1799, " in authorising your Excellency to hold out the idea of compensation to all persons possessed of that species of property (nomination boroughs), and I do not scruple to advise that the compensation should be made on a liberal principle." The purchase of boroughs was no new scheme, having been proposed by Mr. Pitt himself as the basis of his measure for Parliamentary reform in 1785 At the time of the Union the sale of seats in the House of Commons, both in Great Britain and Ireland, was open and notorious. In 1809 an Act was passed which imposed penalties for corrupt agreements for the return of Members, whether for money, office, or other consideration. Notwithstanding, the traffic in seats seems to have continued, but necessarily secretly. From the time of the Act of I809 public opinion went with its policy, and in 1832 so completely coincided with it that the Reform Bill was carried without compensation to the owners of disfranchised boroughs. (See Ball's Irish Legislative Systems, p. 243.) The Government accordingly determined that the purchase of boroughs should form portion of the Union Scheme. The patrons of the boroughs received $f_{6} 7,500$ for each seat, and eighty-four boroughs were disfranchised. The total compensation amounted to $£ 1,260,000$. The same Statute-for whose purposes $f_{1} \mathrm{I}, 400,000$ was granted-provided also that full compensation should be granted to all persons whose offices were abolished or diminished in value by the Union 
(40 Geo. III., c. 34), while rather more than $£ 30,000$ a year was granted in annuities to officers and attendants in the two Houses by a separate Statute. The sum paid for the purchase of the nomination boroughs was added to the Irish National Debt, and thus made a perpetual charge upon the country. Several of the close boroughs were allowed to send one Member to the Imperial Parliament, and, one Member in the British House of Commons being considered equal to two in the Irish House of Commons, no compensation was given. Of the thirty-four boroughs returned, nine only were open. Till the Reform Act, the great majority of the Irish boroughs which were retained after the Union were under the patronage of noblemen and landowners, and places of more consideration than the small nomination boroughs were reduced by restricted rights of election to a similar dependence.

I have called attention to the fact that the Parliament which carried the Union was elected in 1797 , when the subject of the Union had not been broached as a matter of Government policy. We have, moreover, seen that proposals to dissolve Parliament and take the sense of the constituencies on the subject of the Union were resisted by the Government with the utmost determination. At the same time the Government desired to change the composition of the House of Commons which in I 799 had so decisively rejected the measure. "A Place Bill," writes Mr. Lecky, " intended to guard the purity of Parliament against the corruption of Ministers, by compelling all who accepted offices to vacate their seats, had been recently passed, and the Ministers ingeniously availed themselves of this to consummate the triumph of corruption. According to the code of honour which then pre- 
vailed, both in England and Ireland, the Members of nomination boroughs who were unwilling to vote as their patrons directed, considered themselves bound to accept nominal offices and thus vacate their seats, which were at once filled by staunch Unionists, in some instances by Englishmen and Scotchmen, wholly unconnected with Ireland" (Leaders of Public Opinion in Ireland, p. I So).

As early as the 16th May, 1799, we find Lord Cornwallis refusing these nominal appointments to gentlemen when those who were to succeed them in Parliament were opposed to the Union. "Lieutenant-Colonel Cole," he writes, " recently applied to Lord Castlereagh that he might be appointed Escheator of Munster in order to vacate his seat upon his going abroad. (He had been ordered to join his regiment serving abroad.) It appeared in conversation that he intended to have his place supplied by Mr. Balfour, who moved the resolutions against a Union at the County of Louth meeting, and suggested a recurrence to first principles if that measure should be carried. Mr. Tighe had before applied for the same office for one of his members with a view to selling the seat on condition that the purchaser would not support a Union. These requests appeared to me of such a nature as to render it necessary to withhold my acquiescence from them " (Cornwallis Correspondence, III., p. 97.) Lord Cornwallis, however, was able to utilise these nominal offices when the cause of the Union was likely thereby to be promoted. In the few months that elapsed between the prorogation of Parliament on June Ist, 1799, and the Union debates of 1800 , no fewer than sixty-three seats in a House of Commons of 300 members became vacant. In this manner, without a dissolution, 
$V_{\text {more }}$ than a fifth part of the House was renewed. Mr. Grey, in the British House of Commons on April 21st, I 800 , thus stigmatised this fraud on the Constitution: "A Bill," he said, "framed for preserving the purity of Parliament, was abused, and no less than sixty-three

¿seats were vacated by their holders having received nominal offices" (Woodfall's Parliamentary Debates, II., p. 370).

Lord Cornwallis, indeed, tries to take credit to himself for pursuing the policy of overcoming corrupt interests by corruption, ignoring the fact, which has been so frequently demonstrated in these pages, that the Irish Parliament was precluded from reforming itself by the British Cabinet and Irish Administration. "There cannot," he writes on July Ist, I799, "be a stronger argument for the measure (of the Union) than the overgrown Parliamentary power of five or six of our pampered borough-mongers, who can become most formidable to government by their long possession of the entire patronage of the Crown in their respective districts " (Cornwallis Correspondence, III, p. I10).

The patronage of the Crown was most powerfully, inceed almost exclusively, used at this time for the promotion of the Union. "It is," writes Mr. Lecky, "scarcely an exaggeration to say that anything in the gift of the Crown in Ireland, in the Church, the Army, the Law, the Revenue, was uniformly and steadily directed to the single object of carrying the Union" (History of England in the Eighteenth Century, VIII., p. 405). To give a few illustrations: Dr. Agar, the Archbishop of Cashel, agreed to support the Union on being promised the reversion of the See of Dublin and a permanent seat in the Imperial House of Lords. In 
a "private" letter written to the Duke of Portland on July 8th, 1799, Lord Cornwallis states his method of managing the Archbishop: "It was privately intimated to me that the sentiments of the Archbishop of Cashel were less unfriendly to the Union than they had been, on which I took an opportunity of conversing with his Grace on the subject, and after discussing some preliminary topics respecting the representation of the Spiritual Lords and the probable vacancy of the See of Dublin, he declared his great unwillingness at all times to oppose the measures of the Government." Again, Lord Cornwallis writes: "His Grace the Archbishop of Cashel had my promise when we came to an agreement with respect to the Union that he should have a seat in the House of Lords for life." Archbishop Agar was made at the time of the Union an Irish Representative Peer. $\mathrm{He}$ also obtained promotion in the Irish peerage for his Union services. He had been created Baron Somerton in 1795 . He was made Viscount Somerton in 1800 and Earl of Normanton in 1806, and became eventually Archbishop of Dublin. On the death of the Archbishop of Armagh in 1800 the Lord Lieutenant strove with all his might to secure the appointment for Dr. Agar. "I think," he writes, on the IIth March, r80o, "it would have a very bad effect at this time to send a stranger to supersede the whole Bench of Bishops, and I should likewise be much embarrassed by the stop that would be put to the succession amongst the Irish clergy at this critical period when I am above measure pressed for ecclesiastical preferment" (Cornwallis Correspondence, III., pp. 209-210).

A few days afterwards Lord Cornwallis writes again : "Lord Clifden, to whom we stand indebted for seven 
Union votes; Lord Callan, who has two friends in the House of Commons, and Mr. Preston, member for Navan (who became a Union Peer as Lord Tara), all nearly related to the Archbishop of Cashel, came to me this day to request that I would agree to submit his name to His Majesty's consideration for the succession to the Primacy" (Cornwallis Correspondence, III., pp. 217218). In this case the corruptionist interest on the other side of the Channel prevailed. A Dr. William Stuart, the fifth son of the Earl of Bute, the notorious Prime Minister of George III. in the early years of his reign, was appointed. Twenty-three practising barristers voted for the Union in the Irish House of Commons. In I 803 six of them were on the Bench, while eight others had received high honours under the Crown. Thirtytwo barristers voted for the Union at the Bar debate in December, 1798 . In 1803 not more than five of them were unrewarded. On February 19th, I801, Lord Cornwallis thus writes to the Duke of Portland, with reference to the "engagements which he thought it his duty to enter into on the part of His Majesty's Government, and by the directions of His Ministers repeatedly conveyed by His Grace": "Much anxiety is daily manifested by these gentlemen, whose expectations I have not yet been enabled to fulfil, and though I endeavour to impress on their minds an assurance that their just hopes will not be disappointed by any change in His Majesty's Councils, they intimate a wish to receive that assurance from the authority of those with whom the future administration of Ireland may be connected. I am, therefore, to request your Grace will take the earliest opportunity of conferring with His Majesty's Ministers on the subject, and that you will furnish me with an 
official authority to assure all those gentlemen who have any promise of favour in consequence of the Union that they will be fully provided for according to the extent of the engagements made with them, and that no new pretensions will be allowed to interfere with their prior or superior claims" (Cornwallis Correspondence, III., p. 3.39). To this letter the editor of the Cornwallis Correspondence has appended the following remarks: "The promises alluded to in the foregoing letter were recorded in a list enclosed, which it is not considered advisable to publish in extenso. Of these engagements seven were for pensions, one of which, to Mrs. Young, the widew of the Bishop of Clonfert, had ne connection with politics. Thirteen were legal appointments, five of which were completed before Lord Cornwallis left Ireland ; four were for promotions in the peerage; thirty were promises of places varying from $£ 400$ to $£ 800$ per annum, or of pensions from $£ 300$ to $€ 500$. Thirty-five of the persons mentioned in this list were members of the Irish House of Commons who had voted for the Union, and three of the pensions, though granted nominally to persons not in Parliament, were actually to be received by Members. Some of these pensions and places, on account of the change of Government in 1806 , never were conferred, but the Member of Parliament for whose benefit one in particular was intended came to Sir Robert Pee!, when Secretary in Ireland, and claimed the arrears of the pension, amounting to several thousand pounds. It is unnecessary to add that such an application was not successful. Lord Hardwicke, when he assumed the government, recognised the engagements made by Lord Cornwallis, and as far as he was able fulfilled them, but he also resigned before the claimants had been satisfied, and 
the Duke of Bedford, who succeeded him, did not consider himself bound by antecedent promises" (Cornwallis Correspondence, III., p. 349).

The bestowal of peerages, pensions, places, did not exhaust the resources of corruption in the work of carrying the Union. Grattan, who had unusual opportunities of judging, expressed his opinion that of the members who voted for the Union only seven were unbribed (Lecky's Leaders of Public Opinion in Ireland, p. 181). Mr. Hardy, who sat in the three last Irish Parliaments, refrained from writing the history of the Union, and confined himself to the biography of Lord Charlemont, whose death in 1799 was due to an illness superinduced by heart-break at the approach of the Union, giving as his reason that he did not care to bequeath enmities to his children, and that but seven of those who composed the majority in favour of the Union were unbribed (Grattan's Life, V., p. I 13 ).

Mr. O'Connell, speaking in 1843 with reference to the Union, from a personal knowledge of the circumstances of the time, said: "Bribery was unconcealed. The terms of the purchase were quite familiar in those days. The price of a single vote was $£ 8,000$ in money, or an office worth $£ 2,000$ a year if the parties did not choose to take ready money. Some got both for their votes" (Discussion in Dublin Corporation on Repeal of the Union in 1843, p. 36). A year later Mr. O'Connell, when speaking in his own defence in the Irish State Trials in I 844 to a jury composed exclusively of Unionists, said : "You know that there were near three millions expended in actual payment of the persons who voted for the Union " (R. v. O'Connell, p. 638). 
The destruction of the documents relating to Union engagements, to which I have referred, precludes precise knowledge of the incidents of coarse metallic corruption by which it was accompanied. Of the existence of that corruption there can be no doubt, despite the efforts taken to conceal it. Mr. Abbot (Lord Colchester), afterwards Speaker of the House of Commons, was the immediate successor of Lord Castlereagh as Irish Chief Secretary. In his Diary for May, I80I, there is an entry: "The money for engagements of the Union as authorised to be taken out of the privy purse to be settled between Mr. Pitt and Lord Castlereagh " (Lord Colchester's Diary, I., p. 268). The Cornwallis Correspondence abounds in passages which admit the money bribery by which the Union was effected and the acts and stratagems by which it was accompanied. The extracts I cite in this connection are all taken from the Cornwallis Correspondence and are given in their chronological order. On the 17th December, 1799, Lord Castlereagh writes to the Duke of Portland : "Your Grace, I trust, will not be surprised at my requesting that you will assist us in the same way and to the same extent as you did previous to Mr. Elliot's leaving London. The advantages have been important, and it is very desirable that this request should be complied with without delay" (Private and "Most Secret" Cornwallis Correspondence, III., p. 151). The Editor of the Cornwallis Correspondence tells us that the assistance required was a further sum of $£_{5}, 000$. A few days afterwards, on December 28th, Lord Cornwallis writes to General Ross : "My opinions have no weight on your side of the water, and yet I am kept here to manage matters of a most disgusting nature to my feelings " (Cornwallis Correspondence, III., p. 153). 
"I am impatient," writes Lord Castlereagh to Mr. King, on January 2nd, I800, "to hear from you on the subject of my letter to the Duke. We are in great distress, and I wish the transmiss was more considerable than the last. It is very important that we should not be destitute of the means on which so much depends" (Cornwallis Correspondence, III., p. I56). On this letter there is a memorandum in Mr. King's handwriting : " It was sent this day to Lord Castlereagh. I ventured so far as to observe to Lord Castlereagh that the fund was good security for a still further sum, though not immediately, if it could be well laid out and furnished on the spot. I think I did not go too far." When we remember that the opening of the Session was to take place within a few days, on the $5^{\text {th }}$ January, the dates of these letters are not without their significance. On February 4th Lord Cornwallis seems more disgusted than ever with " his dirty business." "I must," he says, " confess that my spirits are fairly worn down, and the force which I am obliged to put on them in public renders me more miserable when I retire" (Cornwallis Correspondence, III., p. I77).

"We require your assistance," writes Lord Castlereagh to Mr. King on February 27 th, "-and you must be prepared to enable us to fulfil the expectations which it was impossible to avoid creating at the moment of difficulty. You may be sure we have rather erred on the side of moderation" (Cornwallis Correspondence, III., pp. 200201). "When," enquires Mr. Cooke of Mr. King, " can you make the remittance promised? It is absolutely essential, for our demands increase. Pray let Lord Castlereagh know without delay what can be done by you" (Cornwallis Correspondence, III., p. 202). On 
the $5^{\text {th }}$ April, I80o, Mr. Cooke is able to send cheering intelligence to Lord Castlereagh: "I have seen the Duke of Portland and Mr. Pitt a second time. The Duke is anxious to send you the needful. Mr. Pitt was equally disposed, but fears it is impossible to the extent. He will continue to let you have $£ 8,000$ to $\ell 10,000$ for five years. I hope to find out to-night what sum can be sent. Mr. Pitt approves of your taking advantage of the vacancies in the Civil List here. Will the law allow you to increase the Commissioners of Boards?" (Cornwallis Correspondence, III., p. 226).

In a letter to Lord Castlereagh, dated London, May 6th, Mr. Cooke says : "I set out for Ireland to-morrow morning. I do not come quite empty-handed " (Cornwallis Correspondence, III., p. 276). On the roth July, 1800, Mr. Marsden writes to Mr. Cooke: "Lord Castlereagh wishes me to remind you of the necessity of supplies. We are in great want" (Cornwallis Correspondence, III., p. 276). "I hope," writes Lord Castlereagh to Mr. Cooke on I2th July, 1800, "you will settle with King our further ways and means. From the best calculation I can make we shall absolutely require the remainder of what I asked for, namely, fifteen, to wind up matters, exclusive of the annual arrangement, and an immediate supply is much wanted. If it cannot be sent speedily, I hope we may discount it here" (Cornwallis Correspondence, III., p. 228).

In a letter of Mr. Marsden to Mr. King, dated December $9^{\text {th }}, \mathrm{I} 800$, the following passage occurs: "I am induced to write to you from the great degree of inconvenience which I am subjected to by the delay in sending over the King's letter for putting into our hands the money saved in the Civil List in this country to be applied to 
the Secret Service here. It has fallen to my lot to make a considerable number of the engagements which this money was to discharge, and I am pressed in some instances in the most inconvenient degree to make good $\mathrm{my}$ promises. There has besides been borrowed from a person here a considerable sum which he is extremely anxious to have repaid. The King's letter for this purpose is, I know, in the Treasury Department, but, as you have a superintending concern for our distresses here, I beg leave to entreat that you will have enquiry made at the Treasury about it. There are some other King's letters which our friends here are looking for rather anxiously, but money is the general desideratum." We may indeed conclude with Mr. Lecky that " direct money bribes were given" (History of England in the Eighteenth Century, VIII., p. 409).

The indignation of Lord Cornwallis and Lord Castlereagh at the conduct of some leaders of Opposition who appear to have attempted to meet corruption by corruption, by subscribing a large sum for the purchase of votes, is amusing when viewed in the light of their own performances. "If we had the means," writes Lord Cornwallis, on the 8th March, I800, "and were disposed to make such vile use of them, we dare not trust the credit of the Government in the hands of such rascals. The enemy, to my certain knowledge, offer $£ 5$,000 ready money for a vote" (Cornwallis Correspondence, III., p. 184). Lord Castlereagh, in a letter to the Duke of Portland, writes with pity, not unmingled with contempt, of the men who were believed to have received bribes to vote, not for the Union, but against it: " Sir R. Butler, Mahon, and Featherstone were taken off by County cabals during the (Parliamentary) recess, and 
Whaley (a brother-in-law of Lord Chancellor Clare) absolutely bought by the Opposition stock purse. He received, I understand, $£_{2}, 000$ down, and is to receive as much more after the service is performed. We have undoubted proofs, though not such as we can disclose, that they are enabled to offer as high as $£ 5,000$ for an individual vote, and I lament to state that there are individuals remaining among us that are likely to yield to this temptation" (Cornwallis Correspondence, III., p. 182).

Mr. Pitt, on January 30 th, 1799 , a few days after the rejection of the project of the Union on its first introduction in the Irish House of Commons, although he had advised the dismissal from office of anti-Unionists, and expressed his fixed determination that the measure should not be dropped, but pressed forward with all the influence at the disposal of the Government, had the temerity in the British House of Commons to describe the measure as a Union "by free consent on just and equal terms." He was very anxious, although he had been apprised by the Lord Lieutenant of Ireland that " the Union was not supported by the people at large," to make it appear in Great Britain that the mass of the people of Ireland were favourable to the measure. It was accordingly determined by the Government to make every effort to obtain signatures to declarations and petitions in support of the Union. The venerable institution of Petition, the oldest of Parliamentary forms, the fertile seed of all the proceedings of the House of Commons, has but little life at the present day. Petition as a means for calling attention to public affairs, and eliciting the expression of the views of the people thereon, has lost much of its importance with the modern growth of the Press and the freedom of combination and assembly which now exists. 
The diminished importance of petitions is one of the most important characteristics of Parliamentary government at the present time, as contrasted with that government in the eighteenth century and in the early decades of the nineteenth century. (See Redlich's Procedure of the House of Commons, II., p. 239.)

In the Parliament of Ireland, as in the Parliament of Great Britain at the same period, great weight was attached to petitions as evidence of the trend of public opinion. Accordingly, one of the methods adopted by the Irish Government during the Parliamentary recess from June Ist, I799, till January $1_{5}$ th, I 800 , was to endeavour to secure largely signed petitions in favour of the Union. "I am preparing," writes Lord Cornwallis on July 2ist, I799, " to set out to-morrow on a tour for three weeks to the South for the purpose of obtaining declarations, etc., in favour of the Union " (Cornwallis Correspondence; III., p. II8). In October the Lord Lieutenant made a journey through Ulster for the same purpose. The signatures the Government could obtain in favour of the Union amounted to no more than about 7,000 , although the signatures to the petitions against the Union were no fewer than 107,000. The history of these petitions has been recorded by Mr. (Lord) Plunket in the Irish House of Commons, and by Mr. (Earl) Grey in the British House of Commons, without fear of contradiction. Mr. Plunket, speaking in the Irish House of Commons on the 16th January, I 800 , thus described the Lord Lieutenant's progress through the country for the purpose of obtaining signatures in favour of the Union: "The representative of Majesty goes out on his mission to court the Sovereign Majesty of the people. It is painful to dwell on that disgraceful 
expedition. No place too obscure to be visited, no rank too low to be courted, no threat too vile to be employed; the counties not sought to be legally convened by their sheriffs; no attempt to collect the unbiassed suffrage of the intelligent and independent part of the community; public addresses begged for from petty villages and private signatures smuggled from public counties. And how procured? By the influences of the absentee landlords, not over the affections, but over the terrors of their tenantry, by griping agents and revenue officers. And after all this mummery had been exhausted, after the lustre of royalty had been tarnished by this vulgar intercourse with the lowest of the rabble, after every spot had been selected where a paltry address could be procured, and every place avoided where a manly sentiment could be encountered, after abusing the names of the dead and forging the signatures of the living, after polling the inhabitants of the gaol and calling out against Parliament the suffrages of those who dare not come in to sign them till they got their protection in their pocket, after employing the revenue officer to threaten the publican that he should be marked as a victim, and the agent to terrify the shivering tenant with the prospect of his turf bog being withheld if he did not sign your addresses, after employing your military commanders, the uncontrolled arbiters of life and death, to hunt the rabble against the constituted authorities, after squeezing the lowest dregs of the population of near five millions, you obtained about five thousand signatures, three-fourths of whom affixed their names in surprise, terror, or total ignorance of the subject" (Plunket's Life, I., pp. 187-188). 
Mr. Pitt seems to have laid much stress on these petitions. Thus, in a letter from Mr. Cooke to Lord Castlereagh, marked "Secret," and dated 5th April, 1800, we find this statement: "He (Mr. Pitt) is anxious that if there be a run of petitions to the King against Union, counter declarations should be renewed if you saw it could be done with success. $\mathrm{He}$ is afraid that if the petitions should become very numerous and not be counteracted, an impression will be made as to the sense of the people being against the measure. He wishes much for counter declarations from our friends." $\mathrm{Mr}$. Pitt was, in this instance, doomed to disappointment. A few weeks after that letter had been written, on April 21st, 1800, Mr. Grey, speaking in the English House of Commons, proved conclusively that "the sense of the people " was against the measure. "It is stated," he said, " in a speech of the Lord Lieutenant to the Irish Parliament, and more clearly and positively in the speech of the Minister, that five-sevenths of the country and all the principal commercial towns except Dublin had petitioned in favour of the Union. This statement I controvert, and shall disprove. The way in which it is attempted to be made out that five-sevenths of the country had petitioned for the Union is by saying that nineteen counties had, and that these counties constitute fivesevenths of the surface of Ireland. That petitions were presented from several different counties I will not deny, but by what means are they obtained, and by whom are they signed ? The Lord Lieutenant, who, besides being chief civil magistrate in the Kingdom, is commander of a disciplined army of 170,000 men, who is able to proclaim martial law when he pleases, and can subject whom he pleases to the military trial of a court-martial in his

* Castlereagh Correspondence, III., pp. 260-26r. 
progress through the kingdom, procured these petitions, which are signed by a few names, and those by no means the most respectable. It has been said that all were Jacobins who opposed the Union. It might be said with more truth that a great proportion of those who signed these vaunted petitions in favour of it were men in the power of the Lord Lieutenant, who were obliged from the fear of punishment to come forward and put down their names. These petitions, however, disrespectable as they are, were clandestinely obtained; not one of them was voted at a meeting called together by the High Sheriff legally constituted, of which there was a reasonable notice. They can with no propriety be called petitions of counties. They are merely those of a few worthless individuals. Yet the right hon. gentleman tells us that they prove the whole Irish nation to be decidedly in favour of the measure. . . . Fortunately, there were many petitions on the other side-petitions which were not obtained by solicitation and at illegal meetings, but at public assemblies, of which legal notice had been given. Twenty-seven counties have petitioned against the measure. The petition from the County Down is signed by upwards of 17,000 respectable independent men, and all the others are in similar proportion. Dublin petitioned under the Great Seal of the city, and each of the Corporations in it followed the same example. Drogheda petitioned against the Union, and, far from Drogheda and Dublin being the only towns which did so, almost every other in the kingdom in like manner testified its disapprobation. Those in favour of the measure, possessing great influence in the country, obtained a few counter-petitions, and had great opportunities of procuring signatures to them; yet, though the petition 
from Down was signed by 17,000 , the counter-petition was signed only by 415 . This instance might be taken as a very fair standard for the whole kingdom. Then there were 107,000 (by an error in the report the number is given as 707,000 ) who signed petitions against the measure ; the total number of those who declared themselves in favour of it did not exceed 3,000 , and many of those only prayed that the measure might be discussed. I wish I could have spoken from official information. Had the motion I made for the Lord Lieutenant been directed to transmit all addresses and counter-addresses which have been received [been carried] I should then have this in my power; at present I must speak from private authority, which, however, 1 believe, will be found to be pretty correct. If the facts I state are true, and I challenge any man to falsify one of them, could a nation in more direct terms, or in a more positive way, express its disapprobation of a political measure than Ireland has of a Legislative Union with Great Britain ? In fact, the Nation is nearly unanimous, and this great majority is composed not of fanatics, bigots, or Jacobins, but of the most respectable in every class in the community" (Woodfall's Parliamentary Reports, II., pp. 396-398).

$\mathrm{Mr}$. Grey estimates the number of signatures in favour of the Union to amount to 3,000 only. Mr. Sheridan, in the same debate, computes them to be 5,000 . The larger figure may include the signatures of those who petitioned not for the passing of the Union, but merely for its discussion. Mr. Lecky, on the authority of $\mathrm{Mr}$. Grattan, states the number of these signatures to be 7,000. It is quite clear that Mr. Pitt would have produced those petitions for which he expressed his anxiety if he considered such a proceeding would have helped his cause. 
Their non-production when actually called for by $\mathrm{Mr}$. Grey proves conclusively their worthlessness. The expression of public opinion against the Union was suppressed by means as base as those by which petitions in its favour were courted.

"It may be said," says Mr. O'Connell, speaking in 1843 , of matters of which he was an eye-witness, "why did not the Irish people resist the fatal measure? How could they ? When the Sheriff of the Queen's County called a meeting of his bailiwick in the town of Maryborough to petition against the Union, he was met by Colonel Connor with two regiments of infantry and detachments of cavalry and artillery, by whom the meeting was instantly dispersed, as the Sheriff was about to take the chair. Again, the High Sheriff of Tipperary convened a meeting of the nobility, gentry, and freeholders of his county. He took the chair, but had been hardly ten minutes in the court-house when it was filled with armed soldiery, who dispersed the meeting at the point of the bayonet. That was the conduct pursued at this eventful period-corruption, bribery, force, fraud, and terror were used, but still the people of Ireland struggled in every mode they possibly could" (Report of the Discussion in Dublin Corporation on Repeal of the Union, I 843 , p. 4I). As Mr. Lecky has truly observed, "It is scarcely an exaggeration to say that the whole unbribed intellect of Ireland was opposed to the Union" (Leaders of Public Opinion in Ireland, p. 166).

The following lines, ascribed to the pen of the late Right Hon. Mr. Justice O'Hagan, who was Judicial Commissioner of the Irish Land Commission, and one of the members of the High Court of Justice in Ireland, summarise the methods by which the Union was carried, 
and indicate the passionate resentment with which the Irish race at home and abroad regard this stupendous crime, which Mr. Gladstone characterised on June 28th, I886, as " the blackest and foulest transaction in the history of man" :

"How did they pass the Union?

By perjury and fraud,

By slaves who sold their land for gold,

As Judas sold his God;

By all the savage acts that yet

Have followed England's track-

The pitch-cap and the bayonet,

The gibbet and the rack ;

And thus was passed the Union

By Pitt and Castlereagh.

Could Satan send for such an end

More worthy tools than they?" 


\section{XXVII.}

\section{THE CARRYING OF THE UNION THROUGH THE IRISH AND THE BRITISH \\ PARLIAMENTS.}

I HAVE dwelt at some length on the steps taken outside Parliament to secure a majority in Parliament for the carrying of the Union. When that majority had been secured by the series of fraudulent transactions recorded in these pages, the Parliamentary proceedings for the consummation of the crime so craftily planned are comparatively of a diminished interest, as there could be no uncertainty as to their result. There was a strict conformity to Parliamentary forms and usages. The Irish Parliament was destroyed in accordance with the letter of the law. One of the most earnest advocates of the maintenance of the Union, in a work specially written in its defence, says: "The miserable tale of the transactions which carried the Treaty of Union teaches at least one indisputable lesson-the due observance of legal formalities will not induce a people to pardon what they deem to be acts of tyranny, made all the more hateful by their combination with deceit " (Dicey's Case of England against Home Rule, p. 25I). These words are an echo of the sentiments of Mr. Bushe, afterwards Lord Chief Justice of Ireland, in a speech of protest against the Union in the Irish House of Commons. "If," he said, "posterity were to believe that frailty and human necessities were so practised on that the private senti- 
ments and public conduct of several could not be reconciled, and that when the Minister could influence twenty votes he could not command one 'Hear him '- I say, not that these things are so, but I ask you, if your posterity believe them to be so, will posterity validate this transaction, or will they feel themselves bound to do so ? I answer, when a transaction, though fortified by a sevenfold form, is radically fraudulent, that all the forms and solemnities of law are but so many badges of the fraud, and posterity, like a great court of conscience, will pronounce its judgment" (Plunket's Life, II., p. 336).

The last Session of the Irish Parliament, for which these dishonourable preparations had been made, opened on | January I $5^{\text {th }, ~ I 800 . ~ T h e ~ s p e e c h ~ f r o m ~ t h e ~ T h r o n e ~ m a d e ~}$ no reference to the matter of the Union, which was uppermost in the public mind. This omission was due to the fact that the vacancies created by the abuse and perversion of the Place Act in the Recess could not be filled till the meeting of Parliament. In the first four days of the new session no fewer than thirty-nine writs Lwere issued for new elections. Sir Lawrence Parsons, having directed the Clerk to read the speeches of the Lord Lieutenant at the opening and the closing of the last session in relation to the Union, moved an amendment to the Address pledging the House of Commoms " at all times, and especially at the present moment, to maintain an independent resident Parliament." The debate extended through the whole night, and lasted for not less than eighteen hours. The conduct of the Government was subjected to the very severest strictures. It was fiercely denounced by Plunket, Burke, Ponsonby, FitzGerald, and Arthur Moore. "You have," said Plunket, " essayed every means to corrupt Parliament, if you could, to sell their country; you have exhausted 
the whole patronage of the Crown in the execution of that system, and, to crown all, you openly avow, and it is notoriously a part of your plan, that the Constitution of Ireland is to be purchased for a stipulated sum " (Plunket's Life, I., p. I89). The debate was memorable for the reappearance of Grattan in the House of Commons, from which he had been absent since his secession in May, 1797. Yielding to the pressure of friends, he came back to Parliamentary life, to defend till the last the Constituticn in whose creation his character and genius had been such powerful factors. One of the members for the nomination borough of Wicklow had just died, the seat was purchased, the election was hurried through on

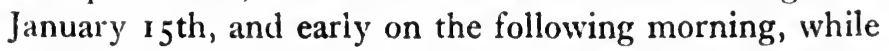
the House was still sitting, Grattan entered the Chamber. His form was emaciated by illness, and he was obliged to lean on Arthur Moore and George Ponsonby as he aivanced to the table to take the oath. The debate was suspended, in accordance with the practice of the time, in order to enable a new member to be swornthe taking of the oath being a matter of Parliamentary privilege. Castlereagh rose at the head of the 'Treasury Bench, and remained standing and uncovered when Grattan took the oaths. Grattan then moved slowly to his seat, and selected a place beside Plunket. He rose to speak, but was obliged to ask permission of the House. owing to physical weakness, to speak sitting. His speech, which lasted for two hours, was marked by all his old fervour and brilliancy. The House divided at ro o'clock in the morning, and the Ministers had a majority of $4 \mathbf{2}$, the numbers being 138 to 96 . On the breaking up of the House a riot took place in the streets, and some of the adrocates of the Union were assailed by the populace. 
The hostility of the City of Dublin to the measure was unmistakable. An aggregate meeting, with the Sheriff at its head, presented addresses to both Grattan and Foster. The Guild of Merchants passed resolutions condemning the Union in the strongest terms, calling for a coalition of all sects against it, and offering warm thanks to their Roman Catholic fellow-citizens of Dublin for their manly and patriotic conduct. A circular, signed by Lord Downshire, the new Lord Charlemont, and Mr. W. Ponsonby, the leader of the regular Opposition, somewhat absurdly described by Cornwallis and Clare as a "consular edict," was issued for the express purpose of obtaining addresses and declarations in favour of the Union, with the results which I have sketched. (See Lecky's History of England in the Eighteenth Century, VIII., pp. 44r-442.) Mr. Lecky draws attention to the fact that few things are more curious than the many resolutions of Orange lodges protesting against the Union. " The Grand Lodge, which passed a resolution in favour of neutrality on the question of the Union, was accused of having betrayed the country under the influence of a few great place-holders. Representatives of no less than thirty-six lodges assembled at Armagh, declared it made no material difference whether the Constitution was robbed by open and avowed enemies or by pretended friends, who were, in reality, the deadliest enemies of the country, and that it was the duty of all Orangemen to stand forward in opposing the impending measure. The representatives of thirteen Orange lodges in the County of Fermanagh at once echoed this language, and very similar resolutions were passed by many other lodges in different parts of Ireland. A large proportion of the lodges, it is true, obeyed the direction of the Grand 
Lodge, and kept silence on the subject, and some individual Orangemen were conspicuous supporters of the Union, but there is not, I believe, a single instance of an Orange resolution in its favour" (Lecky's History of England in the Eighteenth Century, VIII., p. 443). Sir Jonah Barrington records, among "some very serious facts which occurred during the progress of the discussions " on the Union, that the Parliament House " was surrounded by military under the pretence of keeping the peace, which was not in danger, but, in fact, to excite terror " (Rise and Fall of the Irish Nation, p. 278). Lord Cornwallis, in his letters to the British Government between the meeting of the Irish Parliament and the date fixed for the introduction of the Union resolutions, $5^{\text {th }}$ February, begs for the sending over to Ireland of British troops. On the 18 th January he warned the Duke of Portland that dangerous tumults might arise, as a large number of militia-men had been induced by high bounties to volunteer into English regiments. On the 2ist January, the Commons, on the motion of Lord Castlereagh, voted that 10,000 men of the Irish Militia should be allowed to volunteer into the line on a bounty of six to ten guineas per man, and it was afterwards ascertained that their place in Ireland should be supplied by English militia regiments (Castlereagh Correspondence, III., pp. 210-211). It was manifest from this step that the purpose of the Government was not to invite Irish valour to the defence of the Empire in its foreign wars, but to take Irish soldiers from Ireland lest their loyalty might be too severely strained by the destruction of their Parliament by force and fraud, and to have an overwhelming force of British troops in Ireland to quell any disturbance caused by anger at the Union. 


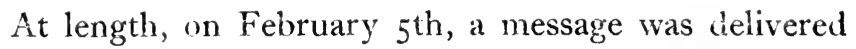
from the Lord Lieutenant to both Houses of Parliament recommending on the part of the King a Legislative Union. Lord Castlereagh, in moving that the message be taken into consideration, in a long and very able speech, unfolded and defended the whole scheme of the Union, but into the details of that scheme it is not within the scope of this work to enter with minuteness. The financial arrangements of the Union, which, to the present hour have borne such pernicious fruit in the artificially-created impoverishment of Ireland, demand more than a passing notice. Mr. O'Connell, throughout his whole long career, insisted that the motive of the Union was an intolerance of Irish prosperity. "I openly assert," he said, when speaking in his own defence in the Court of Queen's Bench in Ireland during the State Trials of 1844 , "I openly assert that I cannot endure the Union, because it is founded on the greatest injustice and based on the grossest insult from an intolerance of Irish prosperity. These were the motives that induced the malefactors who perpetrated that iniquity, and I have the highest authority-an ornament for years of that Bench (Lord Chief Justice Bushe), now, although recently, in his honoured grave-for saying that the motive for carrying the Union was an intolerance of Irish prosperity" $(R$. v. O'Connell, p. 601). Mr. Gladstone, writing in $\mathrm{x} 888$, says : "Ireland loudly and bitterly complains that we have fleeced her, as Dr. Johnson predicted that we should. And I am compelled, after some enquiry into a very intricate subject, to say that, as respects the share of the National Debt charged on her under the arrangements of the Act of Union, her complaint is, in my opinion, one the substance of which it will be found impossible to confute" (Contemporary' Revierv, March, 1888). 
When the Irish Constitution of 1782 was established, the taxation of Ireland was not more than one million a year, and her Kational Debt yas under two millions. At the time of the Union the Irish National Debt, which amounted to $\ell_{72}, 000,000$ in 1794 and $\ell_{1} 4,000,000$ in

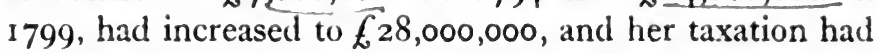
increased to $£ 2,500,000$, which was due to the expenses of the French War, to the expenses incurred in suppressing the Insurrection in 1798 , and to the expenses incurred in the carrying of the measure of the Union by the grossest corruption through the Irish Parliament. Under the provisions of the Union it was arranged that Ireland was, for a fixed number of years, to contribute taxation in the proportion of $z$ to 15 as compared with Great Britain, and that when the National Debts of the two countries, $£_{450}, 504,98_{4}$ British, and $£_{22} 8,545,134$ Irish, came to the same proportion as contributions, the Exchequers might be amalgamated, and a system of indiscriminate taxation established. But the measure of the Union provided that under no circumstances was Ireland to be taxed more than her fair proportion, having regard to her taxable capacity, and that she was to have the advantage of exemptions and abatements as her circumstances demanded. There is also a clause in the Union Treaty which provides that if any surplus revenue should remain after defraying the proportional contributions and the separate National charges of Ireland, the surplus was to be applied to Irish purposes exclusively, and taxes were to be taken off to its amount. It is now admitted that the proportion of 2 to 15 was an unjust proportion, and that the clauses of the Treaty of Union, by which the taxable relations of Great Britain and Ireland were established were framed on the basis of years, not 
of normal, but of abnormal, expenditure. (See Ireland, by Michael F. J. MacDonnell, p. 2r.) In a protest against the Union by Members of the Irish House of Lords, to which the Duke of Leinster was the first signatory, the Irish proportion was estimated as I to i 8 British, and Mr. Speaker Foster, in the Irish House of Cornmons, showed that Lord Castlereagh's proportion of 2 Irish to I 5 British was based on the value of selected items, while others of essential importance were omitted, which, if included, would have greatly lowered his estimate of Irish comparative ability. The profligate proposal that whenever Irish debt should be swollen up to the given standard, then Irish taxes were to be raised to the British leyel, was softened by Lord Castlereagh's suggestion that the given proportion might be worked partly by the increase of the Irish debt, but partly also by the decrease of the British debt. The given ratio, however, was reached solely by the augmentation of the Irish debt without any diminution of the British, and in sixteen years from the Union the Irish debt had increased till it came into the proportion of 2 to $x_{5}$, and then the lixchequers were amalgamated. "If the Union," said O'Connell, " had been a just and equitable compact, the respective debts should have been continued in the same proportion. This, however, was an arrangement too nuanifestly upright and honest to find countenance with them for a moment, and, accordingly, Ireland was afflicted by such an indecent spoliation as exposed her to the ridicule of the world. If, when I was a practising barrister, a deed of partnership was brought to me for legal perusal, and that on looking over it I found that the party who was assenting to the deed was a man owing $£ 21,000$, who proposed going into partnership with a man owing $£ 446,000$, 
and that he was to undertake the liabilities of that partner by virtue of the deed, would I not be inclined to enquire of the attorney in a confidential tone, 'Is our poor client on his way to Swift's Hospital ?' And shall it be said that what is insanity in private life is to be regarded as a rational action when the parties are two countries ?"

Lord Castlereagh thus summed up the benefits of the proposal of Union made by Great Britain to Ireland. It is scarcely necessary to say that every one of his predictions has been falsified. "The proposal," he said, " is one which will entirely remove those anomalies from the Executive which are the perpetual sources of discontent and jealousy. It is one which will relieve the apprehensions of those who fear that Ireland was, in consequence of the Union, to be burdened with the debt of Great Britain. It is one which, by establishing a fair principle of contribution, goes to release Ireland from an expense of $\ell_{1}, 000,000$ in time of war and of $£ 500,000$ in time of peace. It is one which increases the resources of our commerce, protects our manufactures, secures to us the British market, and encourages all the products of our soil. It is one that, by uniting the Church establishments and consolidating the Legislatures of the Empire, puts an end to religious jealousy, and removes the possibility of separation. It is one which places the great question which has so long agitated the country upon the broad principles of Imperial policy, and divests it of all its local difficulties. It is one which establishes such a representation for the country as must lay asleep for ever the question of Parliamentary reform, which, combined with our religious divisions, has produced all our distractions and calamities " (Lecky's History of England in the Eighteenth Century, VIII., p. 455). 
The debate lasted from four o'clock in the afternoon of the $5^{\text {th }}$ February till one on the following afternoon. The division is said to have been the largest ever known in the Irish House of Commons--278 Members, including the Speaker and the tellers, being present. Eight Members only were absent and unpaired. Although the present majority of forty then exceeded by one vote that of January 16 th, it in reality marked a serious retrogression, for on the former occasion a considerable number of seats at the disposal of the Government had been vacant, and no fewer than twelve of the former supporters passed to the Opposition (Lecky's History of England in the Eighteenth Century, p. 457). In the House of Lords the motion, which was moved by the Lord Chancellor and supported by Lord Yelverton, the Lord Chief Baron, who had been so conspicuous a figure on the popular side in the House of Commons in 1782 , was carried by seventy-five votes to twenty-six.

On the 14th February there was a preliminary discussion in the House of Commons on the advisability of postponing the question pending the acquisition of further information. On the 17 th February the Union passed into Committee. A personal attack on Grattan by Corry was met with a crushing reply, which led to a duel, in which Corry was wounded. The Speaker, Mr. Foster, delivered a very closely-reasoned and powerful attack on the measure. After a debate, which lasted for twenty hours, the resolution, declaring that there shall be a Legislative Union between Great Britain and Ireland, was carried by a majority of forty-six. On February $24^{\text {th }}$ the resolution of the relative contribution of the two countries was debated and agreed to. On March $4^{\text {th }}$ the introduction by Ponsonby of a series of resolutions 
declaring that it was the duty of the House to lay the petitions against the Union before the King, and to represent to him the true wishes of the people, were met by a motion for adjournment, which was carried by 155 to 107. On the 1 $3^{\text {th }}$ March a motion by Sir John Parnell, that an address should be presented to the King asking him to dissolve Parliament and take the sense of the constituencies before the Legislative Union was concluded, was defeated by 150 to 104. In the debate on March 19th on the commercial clauses, which was very full, there were two divisions carried by Government majorities of 42 and 47. On March 28th the articles of the Union had passed through both Houses, and they were transmitted to England, accompanied by the resolutions in favour of the measure and by a joint address of both Houses to the King, and then the Irish Parliament adjourned for six weeks to enable them to be carried through the English Parliament, after which they were to be turned into a Bill (Lecky's History of England in the Eighteenth Century, VIII., p. 482).

In the British House of Commons the opposition to the Union was of a very languid character. 'The resolutions passed by the Irish Parliament with reference to the Union were adopted by 208 votes to 26 , and a motion by Mr. Grey, to pray the King to suspend his Ministers' proceedings until the sentiments of the people of Ireland could be ascertained, was defeated by 236 votes to 30 . The clause which permitted the importation of English wool into Ireland was fiercely resisted by the English woollen manufacturers, but was carried by 133 to $5^{8}$. In the House of Lords the Opposition never exceeded twelve, and only once attained that number. The resolutions agreed to by the English Houses, and their joint 
address to the King, arrived in Ireland on May $13^{\text {th. }}$ The Union resolutions were cast into the form of a Bill, and on Miay 2ist the House of Commons, by 160 votes to 100, gave leave for its introduction, and it was at once read a first time. On the 26th May the Bill was read a second time, and on the motion for its committal Grattan made his concluding speech on the Union in the Irish Parliament, which was a very terrible indictment of the Government. In tones of touching eloquence he uttered his last words against the Union: "The Constitution may for a time be so lost, the character of the country cannot be so lost. The Ministers of the Crown may at length find that it is not so easy to put down for ever an ancient and respectable nation by abilities, however great ; by power and corruption, however irresistible. Liberty may repair her golden beams, and with redoubled heart animate the country. Neither the cry of loyalty, nor the cry of the connection, nor the cry of disaffection will in the end avail against the principle of liberty. I do not give up the country. I see her in a swoon, but she is not dead; though in her tomb she lies helpless and motionless, still there is in her lips a spirit of life, and in her cheeks a glow of beauty.

Thou art not conquer'd ; beauty's ensign yet

Is crimson in thy lips and in thy cheeks, And death's pale flag is not advanced there."

In the two divisions that were taken on the committal the Government carried their points by II 8 to 73 and by 124 to 87. The Opposition drew up an Address to the King embodying the case against the Union. This address was moved in the House of Commons by Lord Corry on June 6th, and defeated by 135 to 77 . The Bill then passed quickly through its remaining stages. 
In the House of Lords strong protests were made against the excessive amount of the contribution to be paid by Ireland under the Union arrangements, and there were two divisions, in which the Government had majorities of 59 and 52 . The Bill was then sent to England, where it passed rapidly through both Houses, and it received the royal sanction on the ist of August. (See Lecky's History of England in the Eighteenth Century, VIII., pp. 483-493).

Mr. Lecky pronounces this terrible condemnation of the Act of Union: "In a time of such national peril as England was passing through in the great Napoleon War, when the whole existence and future of the Empire were trembling most doubtfully in the balance, History would not, I think, condemn with severity any means that were required to withdraw the direction of Irish resources from disloyal hands. In such moments of agony and crisis, self-preservation becomes the supreme end, and the transcendent importance of saving the Empire from destruction suspends and eclipses all other risks. But it cannot be too clearly understood, or too emphatically stated, that the Legislative Union was not an act of this nature. The Parliament which was abolished was a Parliament of the most unqualified loyalists; it had shown itself ready to make every sacrifice in its power for the maintenance of the Empire, and from the time when Arthur O'Connor and Lord Edward Fitzgerald passed beyond its walls it probably did not contain a single man who was really disaffected. The dangers to be feared on this side were not imminent, but distant, and the war and the rebellion created not a necessity, but an opportunity" (Lecky's History of England in the Eighteenth Century, VIII., p. 495). 



\section{NOTES \\ ON THE \\ INNER LIFE}

OF THE

IRISH PARLIAMENT. 



\section{NO'TE A.}

\section{LAWS, CUSTOMS, USAGES, AND ETIQUE'TTE}

\section{OF THE IRISH PARLIAMENT.}

\section{Rules of Procedure.}

IN the reign of Elizabeth a Mr. Hooker was member in the Irish House of Commons for Athenry, and in the English House of Commons for Isleworth. Mr. Hooker had, in debate in the Irish House of Commons, incurred much unpopularity by a speech in exaltation of the royal prerogative as opposed to the legislative powers of the Irish Parliament, and as transcending there powers and independent of them. Having regard to his Parliamentary experience in England, he was invited to write, for the guidance of the Irish Parliament, a description of the internal English Parliamentary procedure. His rules, which are set forth in Lord Mountmorres' Irish Parliaments, are of singular interest, since they enable us to understand how business was conducted in the English Parliament in the sixteenth century, and how it was conducted in the Irish Parliament. subject, of course, to the very far-reaching differences in procedure, the results of Poynings' Law and of its statutory modifications (Mountmorres' Irish Parliaments, I., pp. 87-152). One passage from Hooker is of great historical and constitutional value as showing that the relations between the Houses of Lords and Commons in his time were closely analogous to the relations between those Houses 
as established by the provisions of the Parliament Act, 19II. His description of those relations supplies yet another illustration of the theory of Professor Freeman, that in the progress and evolution of the British Constitution we are returning to the old state of things.

" King, Lords and Commons (the three estates of Parliament) may jointly and with one consent and agreement establish or grant any laws, orders, or statutes for the Commonwealth, but being divided and one swerving from another, they can do nothing. For the King, though he be the head, yet alone cannot make any law, nor yet the King and the Lords only, nor yet the King and his Commons alone, neither yet can the Lords and Commons do anything of avail. And yet, nevertheless, if the King in due order have summoned all his Lords and Barons and they will not come, or if they come and appear, yet will not do or yield to anything, then even the King, with the consent of his Commons (who are represented by his knights, citizens, and burgesses), may ordain and establish any acts or laws, which are as good, sufficient, and effectual as if the Lords had given their consent.

"But, on the contrary, if the Commons be summoned and will not come, or coming will not appear, or appearing will not consent to do anything, alleging some just, weighty, and great cause, the King (in these cases) cannot with his Lords devise, make, or establish any law; the reasons are these: When Parliaments were first begun and ordained, there were no prelates or barons of the Parliament, and the temporal lords were very few or none, and then the King and the Commons did make a full Parliament, which authority hitherto never was abridged. Again, every baron in Parliament doth represent but his own person and speaketh on behalf of himself alone. 
"But in the knights, citizens, and burgesses are represented the Commons of the whole realm, and every one of them doth consent, not only for himself, but for all those also for whom he is sent. And the King, with the consent of his Commons, hath ever a sufficient authority to make, ordain, and establish good and wholesome laws for the Commonwealth of this realm. Wherefore, the Lords, being lawfully summoned and yet refusing to come, sit, or consent in Parliament, cannot, by their folly, abridge the King and the Commons of their lawful proceedings in Parliament" (Mountmorres' Irish Parliaments, I., pp. 136-1 38 ).

This description of the distribution of powers between the Houses of Parliament in England, with a view to the adoption of a similar distribution of powers between the Houses of Parliament in Ireland, is an object lesson that in the reign of Elizabeth the relations between the Houses of Lords and Commons were not in practice dissimilar to the position of to-day as established by statute.

THE COSTUMES OF MEMBERS OF THE IRISH PARLIAMENT.

IN the Irish Parliament much attention seems to have been given to matters of costume. In Hooker's rules it is stated, evidently as a practice to be adopted by members of the Irish Parliament, that in the English Parliament in times past none of the members was otherwise than in his gown. In October, $161_{3}$, a very curious discussion took place about the wearing of gowns by members of the Irish House of Commons. Sir John Everard said that the wearing of gowns was fit, alleging 
the example of Julius Cæsar and of Sir John Norris in the last Parliament, which was, however, so long ago as 1585. Sir Christopher Nugent said that a Mr. Hartpole borrowed a short gown in the last Parliament, and then it was agreed upon by the House that, touching the several motions for wearing gowns, the Grand Committee shall peruse and consider of the testimonies and proceedings of the last Parliament (Mountmorres' Irish Parliaments, I., pp. I67-I68). In both Houses the members appeared in levée costume. Lord Strafford, indeed, when Lord Lieutenant, issued a proclamation forbidding the entrance of any member of either House with his sword. All obeyed except the young Earl of Ormonde, who told the Usher of the Black Rod, on demanding his sword, that he should have no sword of his except through his (Black Rod's) body. Equally concise and determined was Lord Ormonde's reply to the inquiry of the Lord Lieutenant as to the reasons for his insolent behaviour. He laid on the Table of the House the writ of summons enjoining his attendance " cinctum cum gladio" or " per cincturam gladii " (Mountmorres' Irish Parliaments, I., p. 219). A very trifling circumstance marks the exactness and gravity of the dress insisted on in the Irish House of Commons. Colonel Tottenham was called "Tottenham in boots," because, having just arrived in Dublin, and hearing of the important question under discussion-a proposal to continue the supplies for twenty-one years, which was in 1729 defeated by one vote only-he hurried down to the House of Commons without giving himself time to take his boots off. The members stared, and the older ones, according to Mr. Thomas Hardy, who served himself in three Parliaments, muttered sadly and loudly at this crying 
innovation, as they termed it. The Lord Chancellor, as Speaker of the House of Lords, and the Speaker of the House of Commons were always attired in their robes of State. In the later years of the Irish Parliament the brilliant uniforms of the Volunteers, worn as Court attire, were conspicuous. The dress of the ordinary members of the House of Commons may be imagined from the description of the dress of Mr. Rigby, who, having been Irish Chief Secretary from I 759 till 1761 , was a member of the English House of Commons with the sinecure office of Master of the Robes in Ireland till his death in 1788. "When in his place" (in the English House of Commons, writes Wraxall), " he was invariably attired in a full dress suit of clothes commonly of a purple or dark colour, with lace or embroidery, with his sword thrust through the pocket." The members of the Irish House of Lords always wore their robes when in attendance in that House. De Quincey, who was one of the spectators in the Irish House of Lords when the royal assent to the Act of Union was given, in a graphic account of the scene which moved him to " unaffected sorrow and solemn awe," says, in his Autobiographical Sketches: "The Peers, having no further title to their robes (for which I could not help wishing that a party of Jewish old clothes men would at this moment have appeared and made a loud bidding), made what haste they could to lay them aside for ever."

MEMBERS OF IRISH HOUSE OF COMMONS RAISED TO PEERAGE-INTERESTING CEREMONIAL.

In the Irish Parliament, as in the case of the wearing of gowns by members of the House of Commons, old Par- 
liamentary practices were observed long after they had fallen into desuetude in England. Thus the custom which was dropped in England in the reign of Henry VII., which seems to have been a remnant of the making of Peers in Parliament, and with the consent of Parliament, the accompanying of a member of the House of Commons who had been raised to the Peerage by his colleagues in the House of Commons to present him to the House of Lords, was in vogue in Ireland at a much later date. In April, 1615, Mr. Farnham moved, upon precedents, that when a member was called by writ or otherwise to the Lords that the House should accompany him thither, which rule was adopted in the case of Walter, Earl of Ormonde, late member for Tipperary. Upon that occasion, Mr. Treasurer St. John told the Lords that they came to present a new member to them as a Peer. The Commons then retired and were recalled to the House of Lords and thanked by the Lord Chancellor, who, however, took care to explain that the new Peer had become a member of the House of Lords, not by reason of " their presentment," but by virtue of the King's Writ (Mountmorres' Irish Parliaments, I., p. I73). On 7 th August, 1662, Lord Ossory, being summoned to the House of Lords by writ, took leave of the House of Commons, and the House, taking into consideration the precedent of the Earl of Ormonde in 1615 , accompanied and presented him at the Bar of the House of Lords (Mountmorres' Irish 'Parliaments, II., p. 127). On the r2th September, 1662, Sir William Temple informed the House that as Colonel Trevor was created Viscount Dungannon, according to ancient precedent as well as a recent example, the House should accompany him to the Bar of the Lords (Mountmorres' Irish Parliaments, II., p. I28). 
Mr. Porritt in his Unreformed House of Commons, which is a monument of patient research and learning, to which I acknowledge my obligations, says : "In the Sixteenth and Seventeenth Centuries the relations of the Commons and Lords in Ireland were marked by a usage of which I can find no trace of a counterpart at Westminster. When a member of the Irish House of Commons became a Peer it was customary for the Commons to grace their late fellow member to the Upper Chamber" (The Unreformed House of Commons, II., p 456). Lord Mountmorres, however, in stating that the custom was dropped in the reign of Henry VIII. in England, adds : "Till which time it is argued in his able treatise by the Chancellor West that all Peers were made by the King and Parliament" (Mountmorres' Irish Parliaments, I., pp. 273-274).

\section{DIFFERENCES BETWEEN THE HOUSES.}

THE differences between the Houses of Lords and Commons in Ireland were seldom if ever on matters of public policy. The influence of the Crown, the immense power over legislation placed in the hands of the Executive by Poynings' Act, the fact that the two Chambers were Houses not of contrasted but of similar origin, and that a large proportion of the Members of the House of Commons were the nominees of the Peers-all prevailed to avert collisions on matters of legislation. The contests and quarrels between the two Houses were on matters of idle etiquette and worthless ceremony. Free Conferences between the two Houses, in which the managers, instead of by formal communication of reasons, attempted by discussion to effect a compromise between the two Houses, were common in Ireland. In 
England no Free Conference has been held since 1836, nor previous to that date since 1740 . The Free Conferences in Ireland were due to a desire to come to a common agreement with reference to legislation to be introduced under the provisions of Poynings' Law, and to influence the Government in the promotion of that legislation and in the settlement of its details. The ceremonial cbservances at these Conferences about sitting down and standing up, as to the place for the Commons to approach, as to whether Peers should be allowed to sit covered, while the Commons were to be obliged to stand uncovered, produced bitter quarrels of a personal character between the two Houses. Lord Strafford, when Lcrd Lieutenant in 1634 , adjusted the controversy by inducing the disputants to submit to the usage of the English Parliament, with which, as an old Member, he was well acquainted. The Duke of Ormonde in 1666 tried to settle the quarrel by deciding that the Loras should sit covered and the Commons stand uncovered in accordance with the English practice. He failed, however, in his efforts as a mediator, and accordingly dissolved the Parliament on August 7 th, 1666 , another Parliament not being convened till 1692 . In 1737 there was yet another violent quarrel between the two Houses, arising out of a slight, actual or imaginary, to which the managers, on behalf of the Commons, were, or believed themselves to be, subjected, from the managers on behalf of the Peers, and thereafter the method of coming to an agreement by Conference was abandoned. Mr. Serjeant Bethsworth, who instigated the House of Commons to persist in this idle quarrel with the House of Lords, is remembered by the sarcasm of Swift :-

"So at the Bar the Booby Bethsworth, Whom half-a-crown o'erpays his sweat's worth, Who knows in law nor text nor margent, Calls Singleton his brother Serjeant." 
The fact that the differences between the Houses of Lords and Commons were on matters of ceremony, rather than on cardinal measures of public policy, is emphasised by the circumstance that in 1792 and 1793 the Irish House of Lords passed all but unanimously measures which admitted the Roman Catholic population to the Parliamentary franchise, and relieved them of all property disqualifications.

WHERE THE PARLIAMENTS OF IRELAND MET.

THE Parliaments of Ireland in early times, like the Parliaments of England, met in various places. Two of the most celebrated of the Irish Parliaments, the Parliament of 1367 , which passed the famous Statutes known as the Statutes of Kilkenny, and the Parliament

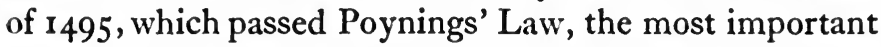
enactments in the whole history of Ireland, met respectively at Kilkenny and Drogheda and not in the metropolis of Ireland. Drogheda seems to have been a favourite place for the meeting of Parliaments. In the reign of Henry VI. six Parliaments met in Dublin, one in Trim, two in Drogheda, and one in Naas. In Edward IV.'s reign five Parliaments met in Dublin, one in Trim, one in Drogheda, and one in Naas. Henry VII. convened two Parliaments in Dublin, one (the famous Poynings' Law Parliament) in Drogheda, and one in Castledermot. In Henry VIII.'s reign six Parliaments, one of which was adjourned to Drogheda, met in Dublin and one in Limerick. In Philip and Mary's reign one met in Dublin, which was adjourned to Limerick. The meetings of Parliament in Naas and Castledermot clearly indicate the great power and influence of the FitzGeralds, then Earls of Kildare, and subsequently Dukes 
of Leinster. From the time of Elizabeth all subsequent Parliaments were convened in Dublin (with the exception of Cromwell's Parliament, if it may be termed by the name of Parliament, which was summoned to meet in Westminster for the three Kingdoms, the members allotted to Scotland being twenty-one and to Ireland thirty). From the meeting of Elizabeth's first Irish Parliament in 1560 till $164 \mathrm{I}$, the Parliaments met in Dublin Castle in rooms arranged for the purpose. From $164 \mathrm{I}$ till I 648 the Parliaments met, not in Dublin Castle, but in the Tholsel, with an occasional meeting in the old Custom House, situate on the banks of the Liffey, at the end of Parliament Street, the reason of the change from the Castle being the fear that some of the members, of whom no fewer than forty were expelled, might be disaffected and their presence in Dublin Castle a source of danger. From 1692 till 1728 , the Parliaments met in Chichester House, on the site of Parliament House, with the exception of the Parliament of James II., which met on the site of the Four Courts, then the King's Inns, a former Augustinian Monastery. From 1728 till 1731 , when the present Parliament House was in course of construction, Parliament met in the old Blue Coat Hospital, since destroyed by fire, in Oxmantown Green, now Blackhall Street (see Mountmorres' Irish Parliaments, I., p. 390 ; II., pp. 97-99; Whiteside's Irish Parliaments, p. 74.; Porritt's Unreformed House of Commons, II., pp. 375-377).

\section{HOURS OF MEETING.}

As in England, so in Ireland, the House of Commons formerly met at a very early hour. The House of Commons of England generally in Tudor times met at 8 a.m. 
and continued till $\mathrm{I} I$, the Committees being appointed to meet in the afternoon. At a later period 10 a.m. was the ordinary time of meeting, and the practice of nominally adjourning the House until that hour continued until I 806 , though so early a meeting had long been discontinued. The Irish House of Commons, according to Hooker's rules, sat from 8 a.m. till I I a.m., while in the afternoon Committees sat (Mountmorres' Irish Parliaments, I., pp. 130-131). In those old times the House itself had frequently two sittings, one before and the other after dinner. As in England, so also in Ireland, the hours for the meeting of the House were fixed at a later time in the day and the sittings were prolonged. In 1763 , on a motion of a member that in consequence of the increase of business Monday should no longer be kept as a holiday, it was urged in debate that the House should meet earlier, that it might not be obliged to sit so late, for that the attendance of that House till 7 or 8 o'clock at nights was a very great fatigue. Mr. Speaker Onslow, in 1759 , complained of the late hour of commencing Parliamentary proceedings in the English House of Commons. "This," he writes, " is shamefully grown of late even to two of the clock; I have done all in my power to prevent it, and it has been one of the griefs and burdens of my life." In the period of Ireland's Parliamentary independence the hours of the Irish House of Commons were as late as those of the English House of Commons, and all-night sittings were not unknown; thus in 1800 the debate on the amendment to the Address to the Throne deprecating a Union lasted from 4 p.m. on January $15^{\text {th }}$ till 10 a.m. on January 16 th, so the debate on the motion that the question of a Legislative Union be taken into consideration lasted from 4 o'clock 
in the afternoon of the 5 th February till $\mathrm{I}$ in the following afternoon. It is of interest to record that O'Connell, in the first year of his Parliamentary career, on the 2nd August, 1830, addressed a letter to the Duke of Wellington, who was then Prime Minister, urging on him the desirability of the meeting of Parliament at an early hour.

The Parliamentary Session in early times was of short duration. On the 22nd April, 1615, a Mr Sutton, one of the Pioneers of Parliamentary Opposition, in moving that, as it tended to the King's benefit, the subsidy Acts might be deferred till other Acts for the benefit of the Commonwealth were read, quoted the old lines "Little said, soon amended, a subsidy granted Parliament ended " (Mountmorres' Irish Parliaments, I., p. 172). To the details of that great measure, the Act of Settlement, is due the longest Parliamentary session in Irish history. The Irish Parliament sat without interruption from the 25th April, 1662, till the 17 th April, 1663. During this session the House of Commons sat 208 days, or five days per week. They sat, however, for twenty days, both in the morning and the afternoon. Till the end of its existence, the Sessions of the Irish Parliament were generally of short duration. Thus, in r794, the Session opened on November 2 Ist and ended March 25th. The Session for 1795 began January 22nd and ended 5 th June, while the Session for 1796 began 21st January and ended 15th April. The Session of 1799 lasted from January 22nd till June Ist, and the Session of 1800 , in which the Union was carried, from January $5^{\text {th }}$ till August ist.

\section{PROXIES AND PROTESTS.}

IN the House of Lords of the Imperial Parliament, not only those Peers who are present may vote by proxy, 
but on certain questions absent Peers are entitled by ancient usage regulated by several Standing Orders to vote by proxy. In 1868 , however, by Standing Order, the House of Lords agreed to discontinue the practice of calling for proxies. In the Irish House of Lords the first vote by proxy was given in 1634 (Mountmorres' Irish Parliaments, II., p. I9I). In Strafford's Parliament 29 proxies were entered, of which 4 or 5 were assigned to one Lord. In 1641 it was ordered that no Peer having estates could vote by proxy without leave of absence from Crown or Select Committee. In I66I an order was made that no Peer could hold more than two proxies. This order was grounded on an order of I640 which had been contravened by Strafford. In Ireland, moreover, Peers were introduced by proxy, with all the formalities of an introduction in person. This custom, however, ceased at the Revolution, owing to the necessity of taking the Parliamentary oath which was enjoined, not by an Irish, but by an English Parliament, by legislation to which no opposition was raised in Ireland. In the Irish Parliament, as in the Imperial Parliament, Peers had the right, without asking leave of the House, to record their opinion and the grounds of it by a protest which is entered on the Journals, together with the names of all the Peers who concur in it. The first protest with reason was recorded in England in 1641 , and in Ireland in 1662. In Ireland Peers had the right of protesting by proxy. In 1765 Lord Hertford, as Lord Lieutenant, expressed a view adverse to the entry of a protest by proxy in the Irish House of Lords, having regard to the English practice, but many precedents having been cited by a Committee, among the rest one of Lord Conway, Lord Hertford's father, the House confirmed 
the privilege (Mountmorres' Irish Parliaments, I., p. 322 ; II., p. 190). The Irish House of Lords till the last claimed and exercised the right of protest by proxy, which in England had fallen into desuetude. In the protest of the Irish House of Lords against the Unionan important State document, of which Grattan is stated to be the author-out of twenty signatures five are stated to be " by proxy."

\section{TACKING.}

THE practice of tacking private grants to Money Bills which the House of Lords, in accordance with constitutional practice, had either to accept or to reject, prevailed in Ireland. Thus, in the Act of Settlement grants to private individuals, each of these grants being virtually in itself an Act of Parliament, were tacked to the Money Bill, and in 1697 a grant to the representatives of Sir Audley Mervyn, a Speaker of the House of Commons in the Parliament of the Restoration, was tacked to a Money Bill. In 1783 , however, a series of very strong resolutions was passed by the House of Lords, by Lord Carysfort condemning this unconstitutional practice with such effect by the House of Lords that every private grant was subsequently sent up from the House of Commons in a distinct and separate Bill (Mountmorres' Irish Parliaments, II., pp. 150-1 52). The English House of Lords, by a resolution of the 9th December, 1702, upwards of eighty years before the resolution of the Irish House of Lords, thus deprecated tacks to Bills of Supply : "That the annexing any clause or clauses to a Bill of Aid or Supply, the matter of which is foreign to or different from the matter of the said Bills of Aid or Supply, is unparliamentary and tends to the destruction of the 
constitution of the Government." The practice adopted in 1861 of the presentation of the financial scheme of the year to the House of Lords for acceptance or rejection as a whole, and the curtailment of the powers of the Lords in respect to Money Bills under the provisions of the Parliament Act 1911, invest the relations between the Irish House of Parliament in respect to Money IBills with an actual interest at the present time.

\section{CHARGES ON PUBLIC REVENUE.}

Three Standing Orders of the British House of Commons, made in the early years of the eighteenth century, which for upwards of a hundred years were the only Standing Orders ordained for their self-government, whose regulations have been from time to time extended and applied, have established the practice, which has been faithfully maintained, that every motion which in any way creates a charge upon the public revenue must receive the recommendation of the Crown. By this practice the great constitutional principle has been established and maintained, that the Sovereign having the executive power is charged with the management of all the revenue of the State and with all payments for the public service. Thus, the Crown demands money, the Commons grant it, and the Lords, subject to the provisions of the Parliament Act, I9II, assent to the grant; but the Commons do not vote money unless it is required by the Crown, nor do they impose or augment taxes unless such taxation be necessary for the public service as declared by the Crown through its constitutional advisers. (See May's Parliamentary Practice, p. 545 ; see also ibid., p. 558.) In the Irish House of Commons this salutary practice did not obtain. Thus, after the 
establishment of Irish Parliamentary Independence, Mr. Bagenal, an unofficial member, without the knowledge of the intimate personal friends of Mr. Grattan, moved that a grant of $\oint_{0} 100,000$ should be made to him, and the proposition was unanimously accepted, but Mr. Grattan's particular friends, at his instance, interposed and declared that nothing would induce him to accept such a grant. At last, however, after some discussion, and acting on the advice of his friends, and upon the urgent wish of the Parliament, he agreed to accept $£ 50,000$, and from this time devoted himself exclusively to the service of his country (Lecky's History of England in the Eighteenth Century, IV., p. 559).

\section{THE EFFECT OF ROYAL ASSENT TO BILLS ON DURATION OF SESSION.}

IT was formerly a matter of doubt both in England and Ireland whether a Session was not concluded by the Royal Assent being signified to a Bill. So far back as 1554 the English House of Commons declared against this construction of law, and yet in 1625 it was thought necessary to pass an Act to declare that the Session should not be determined by the Royal Assent being given to that and certain other Acts, and again in 1670 a clause to the same effect was inserted in an Act, but since that time the law has become modified by usage without any express enactment, and the Royal Assent is now given to every Bill shortly after it has been agreed to by both Houses without any interruption of the Session. The idea that a Session was concluded by the Royal Assent being signified to a Bill has ceased to exist more than two centuries ago. Hooker, in his rules for the Irish Parliament, shows very clearly the prevalence 
of the view that the giving of the Royal Assent to a Bill closed the Session. "If any Bill," he writes, " do pass with their (the Lords') consent the same must be sent to the lower House unless it came first from them (the lower House), and in that case it must be kept to the end of Parliament " (Mountmorres' Irish Parliaments, I., p. 105). In July, 1634, a Bill was brought up from the Irish House of Commons to the House of Lords which provided that Parliament should not determine by His Majesty's assent to certain Bills, and in 1642 yet another Bill was passed to secure that the Session then in existence should not terminate by the giving of the Royal Assent to Bills (Mountmorres' Irish Parliaments, I., pp. 319-320; II., p. 3). "It appears," writes Lord Mountmorres, "from Cotton's Records that the Commons and Lords severally and jointly presented short memorandums of their desires to the King to be framed into laws, to which, if they agreed, they were to be deposited among the records of Parliament till the end of the Session, when the Judges were ordered to draw them up in the regular form as Acts of Parliament, and the completion and passing of these Acts concluded the Session. When this practice was changed by the Royal Assent being given to laws in the middle of the Session it was thought expedient to continue Parliament by an express law, as the dectrine was then prevalent that the Royal Assent to the Bill terminated the Session, and of this there are many instances in early times both in England and Ireland." 


\section{LORD LIEUTENANT'S IRISH STAR-CHAMBER} AND JOURNALS OF HOUSES OF PARLIAMENT.

STRAFFORD, who had a very large Parliamentary experience in England, first as an advocate of popular rights and subsequently as a thorough-going upholder of the prerogative of the Crown, was doubtless well aware that James I., having sent for the Journal of the House of Commons during an adjournment, and on the eve of a dissolution, erased with his own hand the famous protestation of December 18 th, I62I. As Lord Lieutenant of Ireland, he evidently desired to follow in the footsteps of the Stuart King. An entry on the Journals of the Irish House of Commons, dated igth November, I640, runs thus :

“Memorandum : By virtue of His Majesty's letters, we, the Lord Deputy, have at the Council Board had two Orders of the House of Commons, in presence of divers of the late members, torn out of the Journals."

These Orders related to presenting ways and rates to be observed in taxing the growing subsidies, and this Memorandum is signed by Christopher Wandesford, who was the Lord Deputy.

Cn the roth February, I64I, the Order of the 2oth October, I640, which had been erased, was restored. A few days afterwards, on the 17 th February, the House of Commons further vindicated their rights and privileges against the encroachments thereon of Strafford. In a protestation against the preamble to an Act of Subsidies of the last Session, which they declared was foisted in and entered without their knowledge by Lord Strafford and his abettors, they state a proclamation of the King in 1625 , prohibiting all applications to the Lord Deputy 
or Council for justice, and referring law suits in all cases to the ordinary Courts of Law. The references to the Council will remind us that a Council Chamber in Dublin Castle had been established on the same lines, for the same purposes, and with the object of exercising the same jurisdiction by the same methods as the Star Chamber in England. On the 3oth January, 164I, a decree of the Council Chamber against George, Earl of Kildare, was declared by a resolution of the House of Commons to be extra-judicial and contrary to the Great Charter, and this resolution was followed, in July, I64I, by a declaration of the Charter of liberty of the subject (Mountmorres' Irish Parliaments, II., pp. 40-42).

The Council Chamber of Strafford's time in Dublin Castle, like the Star Chamber, fell into disrepute. The Heads of a Bill for its abolition passed by the House of Lords in 1698, were not returned from the English Privy Council. No attempt, however, was made after the Restoration to exercise its jurisdiction, and although not pronounced to be illegal and formally abolished by Statute, like its sister body in England, it ceased to have an active existence. The records of the Irish Star Chamber are out of the reach of the investigation of the historian. Its records of iniquity were destroyed in the great fire in Dublin Castle in 1713 . The Viceroys of Ireland on more than one occasion were guilty of the impropriety of placing on the Journals of Parliament their opinions of its proceedings - a flagrant violation of Parliamentary privilege. Thus, when in 1692 Parliament rejected a Money Bill because it did not take its rise with itself, and passed a resolution explicitly asserting that it was the sole and undoubted right of the Commons to propose Heads of Bills for raising money, 
Lord Sydney, the Lord Lieutenant, entered a protest against the proceedings of the House of Commons in the House of Lords, prorogued the Parliament, and did not suffer it to sit again. In 1769 Lord Townshend, the Lord Lieutenant of the day, in proroguing Parliament, directed that his protest against the action of the House of Commons in rejecting a Money Bill " because it did not take its rise in the House of Commons" should be inserted in the Journals of each House. The protest of Lord Townshend was duly entered in the Journals of the House of Lords, but the Commons, before separating, forbade their Clerk to enter it in their Journals. In the House of Lords a resolution in anticipation of the Lord Lieutenant's protest had been brought forward to the effect that no protest should be entered on its Journals which did not emanate from a member and relate to the business of that House. The resolution was, however, rejected.

\section{THE SPEAKER OF THE IRISH HOUSE OF} LORDS.

IN Ireland, as in England, the House of Lords had a Speaker, who, however, at times, as in England, was not a Peer, but a Commoner. Sir Charles Porter and Sir Constantine Phipps, the founder of the Normanby family, were promoted to the Irish Chancellorship from the Outer Bar of England. On ceasing to hold the Great Seal of Ireland and the Speakership of the Irish House of Lords as Commoners, they returned to England and resumed their position at the Outer Bar of that country in stuff gowns. When a Lord Chancellor is not a Peer, he, as Speaker of the House of Lords, has no more right than to put the question. He has not so much as the 
right to come into the House, for the woolsack is technically outside the House, and a Lord Chancellor who is a Peer advances from the woolsack to a place within the House when he desires to speak in debate. In Ireland, howeve1, theie is an instance of a Lord Chancellor-Sir Richard Bolton-who was not elevated to the Peesage speaking in the House of Lords in 1641 on the question of the position of the Bishop of Killala as a signatory of the Scotch Covenant (Mountmorres' Irish Parliamenis, I., p. 336); and again in April, r644, moving that a Writ of Error was illegal without the King's warrant. "The Chancellor," says Lord Mountmorres, "was a very able lawyer, but it appears odd that he should move and speak as a Peer" (Mountmorres' Irish Parliaments, I., p. 359). The union in the same individual of two such important and laborious offices as those of Lord Chancellor and Speaker of the House of Lords had probably its origin in the fact that the Chancellor generally sat as the King's Steward in his great Court Room or in the assembly of the principal tenants of the Crown, of which the Upper House was composed before it was divided into two Chambers of Parliament, as the Lord of the Manor sat in the Manorial Court merely for the purpose of assembling the members without having a voice or taking part in their deliberations, a power with which he was not invested unless he were created a Peer. The intervention in debate of a Lord Chancellor who was not a Peer was probably permitted by the indulgence of the House to admit of an explanation of some particular matter, just as the intervention of a Steward in a Manorial Court would, under similar circumstances, be allowable at the pleasure of the tenants (Mountmorres' Irish Parliaments, I., p. 415). 
The offices of Lord Chancellor and Speaker of the House of Lords, which are inseparable in England-the Lord Chancellor being ex-officio Speaker of the House of Lords-were in Ireland capable of severance. In 166I, in the first Session of the Irish Parliament after the Restoration, Archbishop Bramhall, the Irish Lord Primate, was Speaker of the House of Lords ; the reason assigned for the filling of the office in this manner was the appointment of Sir Maurice Eustace, the Lord Chancellor, to be one of the Lords Justices for the administration of the Government of the country during the absence from Ireland of the Lord Lieutenant. In the other Parliaments, and from the commencement of the Journals in both Kingdoms, the offices of Lord Chancellor of Ireland and Speaker of the House of Lords in Ireland have been united. The theoretical severance of the offices is brought very prominently before us by the Duke of Rutland, in 1784 , as $\mathrm{V}$ iceroy, wishing to create a Speakership of the House of Lords with a salary distinct from the Chancellorship.

\section{THE SPEAKER OF THE IRISH HOUSE OF COMMONS.}

The Chair and other Relics of the Irish House of Commons.

THE Speaker of the Irish House of Commons was, as has been shown in these pages, like the Speaker of the British House of Commons, at the opening of the nineteenth century, an active member of the House, belonging to a definite party, repeatedly taking a prominent part in the discussions in Committee, as in the cases of Speakers Boyle, Ponsonby, Pery, and Foster. Mr. Speaker 
Foster, the last Speaker of the Irish House of Commons, was a great and acknowledged political power in the country, and his speeches in Committee against the Union are regarded as the ablest contributions to the debates on that question. Boyle and Ponsonby were not only Speakers but eminent political leaders, and Boyle was, at one period of his career, while an occupant of the Chair, an Undertaker. Ponsonby, after his resignation of the Speakership in 1771 , remained, like Sir Edward Seymour in the English Parliament, a prominent member of the House of Commons, and was an unsuccessful candidate for the Speakership in a subsequent Parliament. To Boyle was largely due the defeat of the Court Party in 1753, and Ponsonby in 1769, and Pery in 1772, by casting votes in the Chair, caused defeat of the Administration on cardinal questions of policy, which under a system of responsible government would have entailed an appeal to the country or immediate resignation. The holding of high offices of state, as in the case of Harley in England, who, while occupying the Speaker's Chair, at the beginning of the Eighteenth Century, became Secretary of State and Leader of the Tory Party, was not regarded in Ireland as incompatible with the retention of the Speakership. The delightful old custom which has fallen into disuse in England since 1832 - the taking away by the Speaker at the close of each Parliament of the armchair in which he sat as presidentprevailed in Ireland till the Union. The armchair in which Mr. Speaker Foster sat is an heirloom in the possession of his descendant, Viscount Massereene and Ferrard, as is also the Mace of the Irish House of Commons, which Mr. Foster refused to surrender to any but the constituted authority by whom it had been entrusted 
to his keeping. The Speaker of the Irish House of Commons, who was usually a prime favourite with the people, and regarded as a friend of popular rights and liberties, resided not in the environment of Parliament House, but in a private mansion in the city. In fine weather he used to walk in his robes from his residence to the House of Commons, preceded by the Serjeant-atArms bearing the Mace, and as he passed through the streets was received with honours of which Royalty itself might well be proud. The mention of the Chair of the House of Commons may perhaps be supplemented by the statement that several other relics of the Irish House of Commons are still to be traced. I saw some years ago, in an exhibition in Dublin, the exquisitely-bound prayer-book used by the Chaplain. A magnificent candelabrum was suspended from the centre of the ceiling of the Irish House of Commons. When that Chamber, a few years after the Union, was demolished as part of the conditions under which Parliament House was sold to the Bank of Ireland, the candelabrum was transferred to St. Ancrew's Church, Dublin, which bore in former years the same relation to the Irish House of Commons that St. Margaret's, Westminster, bears at present to the British Parliament. On the destruction of St. Andrew's Church by fire in I 860, the precious relic was saved, and found a place in the Examination Hall of Trinity College, where it still remains. The benches on which the Members of the Irish House of Commons sat are now in the rooms of the Royal Irish Academy, Dawson Street, and are sometimes occupied by the members of that learned body. The destiny of the division bell of the Irish House of Commons is remarkable. It found its way, after the Union, to the 
Theatre Royal, Dublin, and was in use in that establishment for over half a century, sharing its fate when destroyed by fire in February, 1880 .

PROVISION IN THE EVENT OF ABSENCE OF SPEAKER OF IRISH HOUSE OF COMMONS.

In the English House of Commons till i 855 no provision was made for supplying the place of the Speaker by a Deputy Speaker or Speaker pro tempore, and when he was unavoidably absent no business could be done, but the Clerk acquainted the House of Commons with the cause of his absence and put the question for the adjournment. When the Speaker was, by illness, unable to attend for a considerable time, it was necessary to elect another Speaker, with the usual formalities of the permission of the Crown and the Royal approval. In the Irish House of Commons, in the unavoidable absence of the Speaker, a Deputy Speaker was elected so far back as September, 166r, when, at the opening of a new Session, Sir Audley Mervyn, the Speaker, being in England as a member of a Commission, the House chose Sir John Temple, the Solicitor-General, as Deputy Speaker. "This," writes Lord Mountmorres, "is the solitary instance of a Deputy Speaker in the Irish Journals, and when I went through the Journals of the Commons on England I remember to have seen only one instance of a similar proceeding during the Protectorate of Oliver Cromwell (the case of Long, Speaker pro tempore, vice Mr. Chute) (English Commons fournals, VII., p. 612). That it should not be constantly provided for, and that the House might not, according to the convenience of 
Parliament, supply his place upon any occasional illness, has often surprised me" (Mountmorres' Irish Parliaments, II., pp. 107-108).

\section{PAYMENT OF MEMBERS.}

IN the earlier history of the Irish, as of the English, Parliament, Members of the House of Commons were paid wages for their attendance and services in Parliament. The old system of the payment of Members differed from the system of payment recently established. In times gone by the charge was entailed on local funds, the Members being paid by their constituents, whereas at present the charge falls not on local but on Imperial funds. In England and in Ireland alike Knights of the Shire (Members for counties) were paid on a higher scale than citizens and burgesses (the Members for the cities and boroughs), inasmuch as the Knights of the Shire were really persons of higher rank and lived in a more expensive manner. Until 1872 the ancient terms of Knights, Citizens and Burgesses, Barons of the Cinque Ports, the Burgesses of the Universities, were used in the writs and returns, but by the Parliament and Municipal Elections Act, 1872, these distinctions were discontinued, and all are alike termed Members in the writs and returns. For more than a century in England the wages of Members of the House of Commons were sometimes higher and sometimes lower, but at length, in the time of Edward III., they became fixed at 4 s. a day for a Knight of the Shire and 2s. a day for a citizen or burgess, and continued at that rate, with an allowance of a certain number of days' pay for the journey to and fro between their homes and the place of meeting of Parliament. In Ireland the wages of Members of the House of Commons were

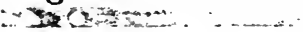


higher than in England. In the time of Elizabeth, according to Hooker, Knights of the Shire were paid I3s. $4 \mathrm{~d}$. per diem-the payment being subsequently reduced to Ios. per diem; while burgesses were paid $5 \mathrm{~s}$. per diem-the payment being subsequently reduced to $3 \mathrm{s.} 4 \mathrm{~d}$. Allowance, moreover, was given from the first day of the journey towards Parliament, the distance to be traversed in a day being 20 miles in winter and 30 miles in summer (Mountmorres' Irish Parliaments, I., p. 95). In the Parliament of James I. the wages of Members of the House of Commons were fixed at I3s. $4 \mathrm{~d}$. per diem for knights, ros. per diem for citizens, 6s. 8d. per diem for burgesses, with an allowance of ten days' pay before the meeting of Parliament and the same allowance after a prorogation (Mountmorres' Irish Parliaments, II., p. 170).

The practice of payment of Members of the Irish House of Commons terminated under the following circumstances : On the 8th July, 1662, Sir John Ponsonby reported the precedents since 1634 , by which it appeared that there was a considerable abatement in the rate of these allowances. This was the last Parliament in which wages were allowed, for in the next Session, on rath March, 1665, an order was made stating that many inconveniences had arisen from the collection of wages, and that no warrants should issue for any wages due since $27^{\text {th }}$ September, I662, or that should be due hereafter. This was accordingly the last time that wages were allowed in Ireland (Mountmorres' Irish Parliaments, II., pp. 122-123). The abolition of the system of the payment of Members may be traced in Ireland, as in England, to the enfranchisement of small boroughs under the influence of the Crown, whose Members, so far from being anxious 
to obtain wages for service in Parliament, were eager to buy seats in the House of Commons, by which to enrich themselves by the methods of Parliamentary corruption then in vogue. In 1560 , in the Parliament of Sussex, ten counties, each returning two Members, were represented; the remaining fifty-six Members, out of a House of Commons of 76 , were returned for boroughs or cities, of which many were merely the creations of the Crown, which had called them into existence. In Porritt's Parliament of ${ }^{2} 585$ there were, out of 126 Members of the House of Commons, 72 Members for cities and boroughs. In the next Parliament, convened in 1613 , in the reign of James I., there were 232 Members, of whom 64 alone were county Members, while in the Parliament of $166 \mathrm{I}$-the Restoration Parliament-there were 246 Members, who, with the exception of 64 representatives for the counties, sat for cities and boroughs. The system of nomination boroughs was always the weakness, and it eventually proved the destruction, of the Irish Parliament. Members of the House of Commons were no longer paid by their constituents, because they were paid for their votes by the Crown. After the Revolution the payment to Members had ceased, and by 1692 the landed aristocracy of Ireland had the boroughs almost as completely under their control as in 1800 , when $f 1,260,000$ was divided among the borough owners at the Union as compensation for the disfranchisement of 84 boroughs (Porritt's Unreformed House of Commons, II., p. 186 ; pp. 197-198).

In England the payment of Members of the House of Commons ceased almost at the same time as in Ireland, and for the same reasons. In March, I676, a Bill for the abolition of payment of Members, introduced by 
Sir Harbottle Grimstone, which produced an animated discussion, was read a second time and silently dropped. It was, however, admitted in debate that the practice of payment of Members was virtually a thing of the past. Andrew Marvell, who sat in that House of Commons, was one of the last Members who were paid wages by their constituents. The last formal payment of wages to a Member of the English House of Commons occurred in 1681, when Thomas King, who had been Member for Harwich, obtained from Lord Chancellor Nottingham a writ de expensis after notice to the Corporation of Harwich. Lord Chancellor Campbell, in his Lives of the Chanceliors, quotes this case, and expresses the opinion that the writ might still (in 1844) be claimed.

QUALIFICATION FOR MEMBERSHIP-ABSENCE

FROM PARLIAMENT-RESIGNATION OF

SEATS IN THE HOUSE OF COMMONSTAKING OF HOLY ORDERS-EXPULSION.

THE constitutional obligation of every Member to attend the Session of the House to which he belongs was in early times enforced in Ireland, not merely on Members of the House of Commons, on whom the penalty of loss of wages could be inflicted with other punishments, but also on Members of the House of Lords, to whom wages were never paid for attendance. Thus, in July, I634, a resolution of the House of Lords was passed and placed on record that Lords must be called to their Parliamentary attendance, and, if not in attendance, pay fines. On the $15^{\text {th }}$ February, 1641, four Members of the House of Lords were fined very severely for nonattendance: the Archbishop of Tuam was mulcted in 
$£_{300}$, Lord Brittas in $£_{150}$, Lord Mountgarret in $£$ roo, and Lord Dunsany in $£ 20$, for non-attendance (Mountmorres' Irish Parliaments, I., p. 344); while on the 18th April, 1644, four Lords were fined $£$ roo each and four other Lords 100 marks each for failure to attend the House (Mountmorres' Irish Parliaments, I., p. 360) In the Irish House of Commons absence from Parliamentary duties was not merely visited by forfeiture of wages. In May, 1615, fifteen Members of the House of Commons were fined by the loss of their wages (Mountmorres' Irish Parliaments, I., p. I26); but in April, 1644, Philip Lord Lisle (a Member of the English House of Peers who was a Member of the Irish House of Commons) and Colonel Crawford were actually expelled for absence without leave (Mountmorres Irish Parliaments, II., pp. 82-83), while in October, 1665, writs were issued in room of four Members absent without leave (Mountmorres' Irish Parliaments, II., p. 137); and in December, 1665, a writ was issued in the room of one Member who had stated he could not soon return to Ireland (Mountmorres' Irish Parliaments,

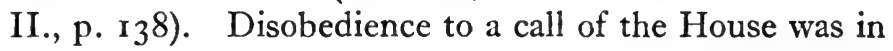
1666 punished by the infliction of a fine of $\oint_{1} 10$ each in the case of no fewer than 84 Members (Mountmorres' Irish Parliaments, II., p. 139). The punishment, however, for non-attendance in either House became obsolete when in both Houses votes grew valuable with the increase of what Grattan has finely termed "the trade of Parliament."

In May, 1662, a rule, which can only be regarded as a rule of perfection, was made by an Order which forbade any Members to record a vote on a question without having heard the debate thereon (Mountmorres' Irish Parliaments, II., p. I I9). 
It is a settled principle of Parliamentary law that a Member, after he has been chosen, cannot relinquish his seat. Technically, a Member of Parliament has no power of voluntary retirement. That a man, after he is chosen, cannot relinquish his seat was definitely laid down by a resolution of the British House of Commons on the 2nd March, 1623. In the Irish House of Commons, however, till 1704, a Member could vacate his seat whenever he so desired-an anticipation of the provision of the Home Rule Act, 1914, that a Member by writing under his hand may resign his seat, and the seat shall thereupon become vacant. In the Irish House of Commons in August, 1634, it was ordered that Sir Barnaby Bryan should have the leave of the House to go to England, but that if he did not return within one week after the next Session of Parliament, then by his own consent a writ should issue for a new election - a course which was eventually adopted. This is the first precedent of issuing a writ by a Member's own desire, of which so many instances occur in the early Journals of the House of Commons (Mountmorres' Irish Parliaments, II., pp. 7-10). It was a constant practice till I704, when, upon the occasion of Mr. Caulfield desiring to vacate his seat to travel for pleasure, a Standing Order was made that writs should not issue any more upon the desire of Members to choose others in their places, and by a further resolution of 1743 the principle so well established in England, that a Member, when once chosen, cannot relinquish his seat by the passing of a Resolution declaring that seats can only be vacated by death, elevation to the Peerage, appointment to the Judiciary, or the taking of Holy Orders. The exclusion of clergy from the House of Commons was long a rule of that assembly, confirmed 
by the Irish Statute, 28th Henry VIII., c. 12. in Hooker's regulations of 1569 it is declared that laymen only are eligible for election. That rule, however, was at least on one occasion contravened, since, in 1628 , William Bedell (Bishop of Kilmore), then Provost of Trinity College, was returned at the Irish Election of Members for the University of Dublin. In England it was a moot question as to whether persons in Holy Orders were eligible for election to the House of Commons. In $180 \mathrm{r}$, Horne Tooke, a Clerk in Holy Orders, entered the House of Commons as Member for Old Sarum. On the roth March following a Committee was appointed to inquire into the eligibility of persons in Holy Orders to sit in the House. The result was the passing of a Bill to prohibit it, and, in consequence, Horne Tooke was unable to offer himself for re-election although he retained his seat during the existence of the Parliament to which he was elected. By the $33^{\mathrm{rd}}$ and $34^{\text {th }}$ Vic., c. 91, s. 4 , when a person has relinquished in due form his office of Priest or Deacon in the Church of England, he is discharged from all disabilities and disqualifications, including that of 41 George III., c. 63 (Horne Tooke's Act), and is, therefore, eligible to sit in Parliament. Ireland never had an Act of Settlement-the provision, therefore, in that Act, excluding placemen or pensioners, which was not to come into operation till the accession of the House of Hanover to the Throne, and, in fact, was repealed before that event, would not have applied to Ireland. The Place Act of Anne (6th Anne, c. 7)whereby it is provided that every Mcmber of the House of Commons accepting an office under the Crown, except a higher commission in the Army or Navy, must 
vacate his seat, but may be re-elected, while persons holding offices created since the $25^{\text {th }}$ October, 1705 , are incapacitated from being elected or re-elected Members of Parliament-had no counterpart in Ireland till 1793, although many efforts were made to obtain a Place or - Pension Act similar to the English Statute. When the Parliament of Ireland adopted the principies of the English Act, the Irish Statute only disqualified for seats in the Irish House of Commons the holders of all offices under the Crown or Lord Lieutenant created after the date of its enactment-there being at that time no fewer than 116 placemen out of the 300 Members of the Irish House of Commons. Writing in 1793, a year before that enactment, Lord Mountmorres said: "Employments in Ireland do not vacate seats, and, in England, the Chiltern Hundreds appear to have been devised to carry a point by a mancuvre." In order to evade the restriction placed upon leaving Parliament by a Member elected thereto, a method of effecting a retirement was devised by the acceptance of a nominal office under the Crown, whereby, under the provisions of the Place Act, a seat is vacated. The offices usually selected for this purpose are the offices of Steward or Bailiff of His Majesty's thrce Chiltern Hundreds of Stoke, Desborough, and Burnnhan, and the Steward of the Manor of Northstead, which, though the offices have been refused, are ordinarily given by the 'Treasury to any Member who applies for them. This method of resigning a seat in the House of Commons is still in vogue, and its anomalous character was thus described by Sir William Harcourt, spesing as Leader of the House of Commons on 3 ist January, 1893: "The whole proceding is merely a constitutional fiction, equivalent to a resignation. It is 
certainly an anomalous and inconvenient fiction. A former Member of this House, Sir Henry Drummond Wolff, in 1880 , intimated that he would move for a Committee to alter the system. I am sorry he did not do so, because I think it would be very desirable that another form of resignation should be established by this House." In Ireland, after the passing of the Place Act in 1793, appointments to four nominal offices under the Crown were used as a method of resigning a seat in the House of Commons, just as appointments to the Chiltern Hundreds and the other kindred nominal offices under the Crown are used in England. By means of these offices Lord Castlereagh packed the Irish House of Commons in 1880 , and succeeded thereby in the carrying of the Union.

By order of the Irish House of Commons on the 26th May, I64I, when a writ was issued for a Member to serve for Augher in the room of Captain Paisley, the election of any one under age is forbidden (Mountmorres' Irish Parliaments, II., p. 60). In England the election of any one who is not twenty-one years of age is made void by a Statute of William III. (7\&8 Wm. III., c. 25). Hatsell, in his Precedents, remarks that the poet Waller sat in Parliament in 1622 before he was twenty-one years of age, and it is certain that members were occasionally admitted in despite of the provisions of the Statute. Charles James Fox was returned and sat at the age of nineteen, but Chesterfield (then Lord Stanhope), under similar circumstances, received from the Ministry of the day, whom he had attacked, a hint, on which he acted, that he must withdraw.

On the I9th July, 1634 , there is a record of the expulsion of Sir J. Bramston, Sovereign of Belfast, as his own returning officer. That a returning officer cannot be 
himself elected for the constituency of which he is a returning officer is a well-known principle of Parliamentary law (Mountmorres' Irish Parliaments, II., p. 2). 'Thus, in $\mathrm{IS}_{74}, \mathrm{Mr}$. Parnell, at the General Election of that year, wished to be a candidate for the representation of Wicklow County in Parliament. He happened, however, to be High Sheriff of that County, and as such its returning officer, and was accordingly disqualified. In the representation in the Irish House of Commons of Trinity College, in two instances at least, Provosts who were themselves the returning officers were elected. In 1613 William Temple, then Provost, was returned as one of the Members for Trinity College, when it became for the first time enfranchised. In I628 William Bedell, the Provost, who was also a Clerk in Holy Orders, was elected as one of the Members for Trinity Collegea position which he subsequently vacated. So far back as 1569 , in a Parliament summoned by Sir Henry Sidney, the judges, on reference to their opinion, held that the election of returning officers was illegal.

\section{TONE OF THE IRISH HOUSES OF PARLIAMENT.}

“ LORD Powerscourt for some time attended the (Irish) House of Lords. But he soon discovered that although he wished to engage in business, the Upper House of the Irish Parliament was, of all places on earth, the most unpropitious to any such laudable pursuit. An ungenerous and unwise policy had withered almost all the functions of that assembly, and the ill-omened Statute of George I. hung on it like an ineubus. He was much mortified at finding himself in the company of such august but imbecile, inefficient personages, who moved almost 
more like the shadows of legislators than genuine and sapient guardians of the realm or counsellors to Majesty. He soon grew weary of them. To an intimate friend of his, who often repeated the circumstance to me, he lamented that he was not born a commoner, and some time after he proved that he was not affectedly querulous or insincere in the regret which he expressed, for he procured a seat in the English House of Commons. While he sat there he spoke not infrequently; his speaking was much approved of, and he began to relish the new scene of life into which for the best purposes he had now entered. But procrastination renders our best efforts ineffectual - a severe malady soon overtook him; he resigned his seat in the House of Commons, and, after struggling with uninterrupted ill-health for some time, he died, universally beloved, in the prime of life, having scarcely passed his thirty-fourth year" (Hardy's Life of Charlemont, I., pp. 213-214).

Mr. Hardy, the biographer of Lord Charlemont, thus describes the House of Lords of Ireland in the fifties of the eighteenth century, when Lord Charlemont began to take an active interest in Irish public life:

" Lord Chesterfield thought proper to term the House of Lords in England an hospital of incurables, but by what application he would have distinguished the Irish House of Lords at this juncture I cannot well conceive. However, it reflects no discredit on their Lordships that, borne down as they were by a power they could not resist, their journals, session after session, present nothing but an unvaried waste of sterility or provincial imbecility. The proceedings of many a solemn day in the first assembly of the Kingdom are recorded in the following brief chronicle, 'Prayers. Ordered that the Judges be 
covered. Adjourned.' But whatever their unimportance, they seem in the shreds and patches of their political capacity to have been the most versatilely civil, obsequious noblemen that could possibly exist. On the approaching departure of the Duke of Devonshire in 1756, they address His Grace in the following manner : 'We shall esteem ourselves greatly favoured by His Majesty (whom God long preserve) in the continuing of your Grace in that high station you now so eminently fill. For we are convinced that your frequent appearance in that office will add new lustre to the reign of our royal sovereign, stability to our power, etc.'

"The next year, 1757, the Nation was engaged in war, and His Majesty had, according to their account, "an unnatural conjunction of powers to contend with.' What was their Lordships' consolation ? Let us attend to their adidress to His Majesty : 'When such formidable designs are laid to deprive us of all our constitutional rights and liberties, it must raise the highest and greatest confidence as well as the warmest returns of gratitude and loyalty in every Protestant bosom to know that they are committed by His Majesty's great wisdom and goodness to the care of '- not the Duke of Devonshire, whose frequent appearance among them was to add such lustre to the Throne-but to the Duke of Bedford, a most respectable nobleman, certainly very dissimilar, however, in many points to his predecessor. But any Viceroy would at that time, or indeed long after, have been equally complimented : such unvarying adulation can excite no unity, it inspires far other sentiments " (Hardy's Life of Charlemont, I., pp. 103-104).

Speaking of the Irish Parliament of the early years of George III.'s reign, Mr. Hardy writes : 
" Refinement of language was not to be found in Parliament at this time, nor for many years preceding. So far from it, that an unlettered style almost approaching to coarseness and vulgarity was the only one permitted by the House of Commons. Some of the old Members (such is the force of habit) insisted that business could not be carried on in any other, and the younger Members, till Mr. Hutchinson appeared, would not venture to contradict them. The genuine business of the House will always remain in the hands of a few, but Parliamentary speaking in those days was also confined to a few, the Secretary, the leading Commissioners of the Revenue, the Attorney-General, and one or two grave Serjeantsat-Law. If a contested election or some such question called for the exertions of the gentlemen last mentioned, they never thought of closing their speeches till repeated hints from their Party obliged them to do so. If, to the dismay of the House, they rose near midnight, they were as certain, though sad, harbingers of day as 'the bird of dawning' ever was. 'The House was astonished at the laborious constancy of such men, and often resigned all speaking to them in a kind of absolute despair" (Hardy's Life of Charlemont, I., pp. 140-14I). 
NO'TE B.

\section{THE IRISH PARLIAMENT AND MATERIAL} PROSPERITY.

IT has not fallen within the scope of this work to treat of the efforts of the Irish Parliament to promote the prosperity of their country, except in the cases in which these efforts form part and parcel of the constitutional history of Ireland. The struggle of that Parliament, under the most disheartening circumstances, to develop Irish resources, reflects credit on its extraordinary ingenuity and its patriotism. It should never be forgotten that Ireland was the victim of the direct legislation of the English Parliament, avowedly contrived to hinder the development of her commerce and manufactures. Mr. Balfour, speaking at Alnwick on July r 9 th, r895, admitted that England had destroyed Irish industries. "There was," he said, " a time, an unhappy time, when the British Parliament thought they were well employed in crushing out Irish manufactures in the interests of British commerce. It was a mad, and it has proved to be a stupid, policy." Till the Restoration no legislative disability rested upon Irish industry. The English landowners complained that Irish rivalry in the cattle market lowered English rents, and legislation enacted between 1663 and 1680 absolutely prohibited the importation into England from Ireland of all cattle, sheep, and swine, of pork, bacon, and mutton, and even of butter and cheese. An English Act passed in 1663 
(15 Char. II., c. 7), entitled " An Act for the Encouragement of Trade," prohibited the importation of Irish cattle into England, and imposed a penalty on every head of such cattle imported. It likewise prohibited all exports from Ireland to the Colonies except victuals, servants, horses, and salt for the fisheries of New England and Newfoundland. A subsequent English Act declared the importation of Irish cattle into England to be a "publick and common nuisance," and forbade the importation of beef, pork or bacon (18 Char. II., c. 2). The exportation to Ireland from the English Plantations of sugar, cotton wool, tobacco, indigo, ginger, fustian, or other dyeing wool, the growth of the plantations, was forbidden by Statute (22 and 23 Char. II., c. 26).

Being forbidden to export their cattle to England, the Irish landowners turned their land into sheep walks, and began on a large scale to manufacture the wool. The exportation of Irish woollen goods to England had already been subject to a duty equal to a prohibition ( 12 Char. II., c. 4), but this did not at the time inflict material injury on Ireland, as there was an important woollen manufacture in England. After the Revolution, however, the English manufacturers urgently petitioned for the total cestruction of the woollen industry in Ireland. An English Statute of 1698 (10 \& II Wm. III., c. 10) recites that "wool and wocllen manufactures of cloth, serge, bags, kerseys, and other stuffs, made or mixed with wool, are the greatest and most profitable commodities of the kingcion, on which the value of land and the trade of our nation do chiefly depend, and that great quantities of the like manufactures have of late been made and are daily increasing in the Kingdom of Ireland and in the English Plantations of America, and are exported from 
hence to foreign markets heretofore supplied from England, all which inevitably tends to injure the value of lands and to ruin the trade and woollen manufactures of the Realm, and that for the prevention thereof the export of wool and of woollen manufactures from Ireland be prohibited under forfeiture of goods and ship, and a penalty of $£ 500$ for every such offence." In reply to Addresses presented to King William III. by both Houses of the English Parliament on 9th June, 1698, his Majesty said : "I shall do all that in me lies to discourage the woollen manufacture in Ireland and encourage the linen manufacture there, and to promote the trade of England " (English Commons' Fournals, XII., p. 539). Ireland's woollen manufacture was thus sacrificed to England's commercial jealousy, and the promise solemnly made to foster the linen manufacture was, in the words of Lord North, speaking in the English House of

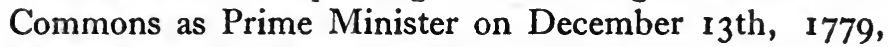
nearly a century later, when proposing the removal of some of the restraints placed by English legislation on Irish trade, " no sooner made than it was violated by England," for, instead of prohibiting foreign linens, duties were laid on and necessarily collected, so far from amounting to a prohibition on the imports of the Dutch, German, and East Country linen manufacturers, that these manufacturers have been able, after bearing duties imposed on them by the British Parliament, to meet, and in some instances undersell, Ireland, both in Great Britain and the West Indies, and several other parts of the British Empire (Parliamentary Debates, XV., p. 18I). In $175^{\circ}$ heavy taxes were laid on the imports to England of sail cloth made of Irish hemp, contrary, of course, to the express stipulation of 1698 . Every industry or trade 
to which the Irish people had recourse was crushed in a similar manner-cotton, glass, iron, hats, sugar-refining, ship-building-every industry to which Ireland turned was destroyed by England, by the imposition of prohibitive duties and by the closing of the ports. The Colonial and Indian markets were closed absolutely against Ireland, while prohibitive duties were placed on all Irish manufactures so as to keep them out of the English markets. Lord Dufferin has admirably summed up English interference with Irish industries, which I have thus sketched in faint outline. " One by one," he writes, " of each of our nascent industries was either strangled at its birth or handed over, gagged and bound, to the jealous custody of the rival interests of England, until at last every fountain of wealth was hermetically sealed, and even the traditions of commercial wealth have perished through desuetude." This code, atrocious as it was, still failed to come up to the mark in the judgments of the selfish and unscrupulous profiteers in whose interests it was established. " In the year 1698," writes Hely Hutchinson, "two petitions were preferred from Folkestone and Aldborough stating a singular grievance that they suffered from Ireland 'by the Irish catching herrings at Waterford and Wexford and sending them to the Streights, and thereby forestalling and ruining petitioners' markets,. but these petitioners had the hard lot of having motions in their favour rejected "(Commercial Restraints, pp. 125-126).

Mr. Fox, speaking in the British Parliament on May $17^{\text {th }}, 1782$, as a responsible Minister of the Crown, thus stated the nature and effect of the legislation of that Parliament with reference to Irish trade: " The power of external legislation had been employed against Ireland 
as an instrument of oppression to establish an impolitic monopoly in trade to enrich one country at the expense of the other" (Parliamentary Register, p. 7).

The English Government was, previously to the Revolution of 1782 , able to dominate the legislation of the Irish Parliament under the provisions of Poynings' Law. While the British Parliament placed prohibitory duties on Irish goods, it was quite impossible for the Irish Parliament to exercise a similar power. No Irish Bills could before 1782 become law, or indeed in strictness be introduced into the Irish Parliament, without the sanction of the English Privy Council, which would, of course, in the case of Bills of this character, be withheld.

The Irish Parliament, bound thus hand and foot, by a rapacious tyranny, did all that lay in its power to be a vigilant and intelligent guardian of the national interests of the country. "The system of (Irish) Government," writes Mr. Lecky, " though corrupt, anomalous, and exposed to many dangers, was not one of those which are incompatible with a great measure of national prosperity. There were unfair monopolies of patronage; there was a pension list of rather more than $£ 100,000$ a year, a great part of which was grossly corrupt; there was a scandalous multiplication and a scandalous employment of sinecures, but these were not the kind of evils that seriously affect the material well-being of the community. In spite of much corrupt expenditure, the Government was a cheap one. Ireland was amongst the most lightly-taxed nations in Europe, and, with the exception of the tithe system, which was unjust in the exemption of pasture (an exemption not legalised but secured in practice by a resolution of the House of Commons in 1735), and which in some parts of the country fell with a most oppressive weight upon 
the poor, there was little to complain of in the apportionment of public burdens " (Lecky's History of England in the Eighteenth Century, VI., p. 444).

Mr. Foster, the last Speaker of the Irish House of Commons, who had previously filled the office of Chancellor of the Irish Exchequer, who subsequently to the Union was, before the amalgamation of the British and Irish Exchequers in 1816 , Irish Chancellor of the Exchequer, and was admittedly one of the greatest financial experts of his generation, spoke thus in the Irish House of Commons on 12th April, 1800, in a Union debate: "The British Minister wants a Union in order to tax you and take your money when he fears your own representatives would deem it improper, and to force regulations on your trade which your own Parliament would consider injurious or partial. I never expected to have heard it so unequivocably acknowledged, and I trust that it will be thoroughly understood that it is not your Constitution he wants to take away for any supposed imperfection, but because it keeps the purse of the nation in the honest hands of an Irish Parliament."

The Irish Parliament had at first but little power except that of protesting against laws crushing Irish commerce and of making feeble efforts to develop the resources of the country and to guard them from unjust taxation. What little that Parliament could do it appears to have done, as its journals show a minute attention to industrial questions, to the improvement of means of communication, to the execution of public works. In 1703, 1705, 1707, the House of Commons, when the country was reduced to the very lowest state by the destruction of the woollen trade, resolved unanimously that it would greatly conduce to the relief of the poor and 
the good of the Kingdom that the inhabitants there. of should use none other but the manufactures of this Kingdom in their apparel and the furniture of their houses, and in the last of these Sessions the Members engaged their honour to conform themselves to this resolution (Lecky's History of England in the Eighteenth Century, II., p. 214). In 1708 spinning schools were established in every county, and premiums were offered for the best linen, and a Board of Trustees was appointed in 1710 to watch over the interests of the capital. In r 70r, moreover, pensions to the amount of $£ 16,000$ were struck off owing to the pressure brought to bear upon the Government by a Parliament indignant at the ruin of the woollen trade. The helplessness of the Irish Parliament during this period is demonstrated by Hely Hutchinson, who states that in 1721 , during a period of great distress, the Speech from the Throne and the Addresses to the King and the Lord Lieutenant declare in the strongest terms the great decay of trade and the very low and impoverished condition to which the country was reduced. "But," he says, "it is a melancholy proof of the depending state of this Kingdom that no law whatever was then proposed for encouraging trade or manufacture, or, to follow the words of the Address, "for reviving trade and making us a flourishing people,' unless that for amending laws as to butter and tallow casks deserves to be so called. And why ? Because it was well understood by both Houses of Parliament that they had no power to remove those restraints which prohibited trade and discouraged manufactures, and that any application for that purpose would at that time have only offended the people on one side of the Channel, without bringing relief to those on the other" (Commercial Restraints, pp. 40-41). In 1727 
the Privy Council allowed a Bill, framed on the model of an English Statute, to become law, entitled " An Act to encourage Home Consumption of Wool by Burying in Wool only," providing that no person should be buried in any stuff or thing other than what is made of sheep or lambs' wool only. The custom, now grotesque and unmeaning, of wearing linen scarves at funerals was recommended by the Irish Parliament in the interests of the linen manufacture, and was first introduced in 1729 at the funeral of Mr. Conolly, Speaker of the Irish House of Commons. In 1729 also a measure was carried by which all salaries, employments, places, and pensions of those who did not live in Ireland six months in the year were taxed four shillings in the pound, but the unfortunate qualification was added, " unless they should be exempted by His Majesty's sign warrant." The Statute thus rendered useless had become, in 1753, a dead letter. It was re-enacted in 1767 without the provision for exemption, but it was evaded by grants from the public funds equivalent to the taxes imposed.

The Irish Parliament, moreover, when the trade of their country had been destroyed, endeavoured to provide means of subsistence for their people by the encouragement of tillage. In 1716 the House of Commons unanimously passed a resolution that covenants which prohibited the breaking of the land with the plough were impolitic, and should have no binding force. They, moreover, passed heads of a Bill enjoining that for every hundred acres which any tenant held he should break up and cultivate five, and, as a further encouragement, that a trifling bounty should be granted by the Government on corn grown for exportation. The Bill came back from the Privy Council, but a clause had been slipped in 
empowering the Council to suspend the premiums at their pleasure, and the House of Commons in disgust refused to take back a measure which had been mutilated into a mockery. It became law in 1727 (I Geo. II., c. 10), but was wholly ineffective. Among the Irish papers at the English Record Office there is one sent from Ireland, April 16th, 1774, enumerating the different Acts that have been passed relating to Irish tillage. To the Statute of 1727 the following note is appended: "This law, though a perpetual one, has never been observed nor attended to in a single instance."* The desire of the Irish Parliament to encourage tillage in the interests of the people was most marked. In 1759 a law was passed granting bounties charged on the hereditary revenue on the land passage of corn and flour to Dublin. In 1774 the burden of these perpetual duties in the Lord Lieutenancy of Lord Harcourt was partially removed from the hereditary revenue of the Crown by a resolution of the House of Commons to the effect that whenever the burden on the inland carriage of corn exceeded $£ 35,000$ in the year, Parliament should impose fresh taxes to make good the excess (Lecky's History of England, II., p. 435 ; IV., p. 415). In 1797 the bounty on the inland carriage of corn to Dublin was abandoned by the House of Commons, which had then become absolutely subservient to the Government. In 1771 the heads of a Bill were introduced to prevent corn from being wasted in making whiskey, and to put some restraint on the vice of drunkenness, which was then increasing. The Bill was warmly recommended by Lord Townshend, the Lord Lieutenant of the day, to the Privy Council, but was rejected " because the Treasury," in the words of Mr.

* Lecky's History of England in tine Eighteenth Century, II., p. 248 ; IV., p. 312. See also Froude's English in Ireland, I., pp. 44I-446. 
Froude, "could not spare a few thousand pounds which were levied upon drunkenness."

English influence, notwithstanding the struggles of the Irish Parliament in the interests of the Irish people, dominated in Irish legislation, and would suffer no measure that would interfere with the English corn trade before the establishment of Irish Parliamentary Independence in 1782 . Some bounties on corn exportation were granted in 1707 , but they were far smaller than those in England, and they only came into operation when the price had come to a level it scarcely ever reached. They were slightly increased in 1756 , in 1765 , and in 1774, but were still too low to have any considerable effect. The Act making it compulsory to till five acres in every hundred was little more than a dead letter, and no good result can have followed from an Act of 1765 , which offered premiums to the landlord and farmer in each county who had the largest quantity of corn on stands four feet high with flagstones at the top. Some considerable effect, however, is said to have been produced by these various Acts, which offered bounties on the inland carriage. $\dagger$ To the establishment of Irish Parliamentary Independence in 1782 is due the memorable Statute known as Foster's Act ( 23 and 24 Geo., III, c. 19), which proved an inestimable benefit to the Irish Nation. This Act, named from the Speaker of the House of Commons, who, as Chancellor of the Exchequer, in 1784 , introduced it in the House of Commons, has been described by writers who have examined the economical condition of Ireland as incomparably the most beneficent measure of the Eighteenth Century. It was modelled on the English Corn Laws as they had existed since the Revolution. A bounty of 3 s. 4 d. a barrel on the export

* English in Ireland, II., p. I I 4.

$\dagger$ Lecky', VI., pp. 356-357. 
of wheat was granted as long as the home price was not above 275. a barrel, and other very considerable bounties on the exportation of flour, barley, rye, oats, and pease, and it at the same time laid a duty of ros. a barrel on imported wheat when the home price was under 30s., and a number of other duties varying according to the home price on the importation of the other articles that have been mentioned. Mr. Lecky, from whom I have taken this description of Foster's Act, quotes the appreciation by Newenham of that measure with evident approval. Newenham mentions, writing in 1809 , that since the passing of that Act acute distress in Ireland ceased, manufactures flourished, in consequence of increased profits in agriculture, and while population rapidily augmented, the well-being of all classes steadily rose. "Those views," writes Mr. Lecky, " appear to have been very generally held, and the corn bounties received the warm and almost unanimous approbation of Parliament. It is impossible, indeed, to question the magnitude of the change that followed them-vast pasture lands were rapidly broken up into small tillage farms, corn ricks were erected in every quarter of the land, and a great corn trade was produced. The quantity of corn, meal, and flour exported in twelve years after the passing of the Act exceeded that which was exported in the eighty-four years that preceded it. Its value in the years after 1785 was almost four millions and a quarter. It may, I think, be truly claimed for Foster's Act that in a country where there was very little capital and enterprise, it turned agriculture decisively and rapidly in this profitable direction. It was enacted at a time when the growth of the manufacturing population in England had begun to press heavily on the nation's means of subsis- 
tence. England ceased to be a wheat-exporting country --the vast market was thrown open to Irish corn, and a few years later the French War raised the price of wheat almost to a famine rate, and made the profits of corn culture proportionately large."*

The efforts of the Irish Parliament to promote agriculture, both before and after 1782 , which I have thus outlined, are typical of the work of a body of men who took a real interest in the material welfare of their country which was too strong to be repressed by enervating hostile influence. Many measures of practical, unobtrusive utility were passed, and an effective check was placed on the extravagance of the Executive. The English poor law of Elizabeth was never applied to Ireland, but in 1703 in Dublin, and in 1735 in Cork, workhouses and corporations for the management and the relief of the destitute were established by Statute (Lecky, II., pp. 253254). The Royal Dublin Society was assisted by considerable grants from the Irish Parliament, as was also Trinity College, Dublin, to the erection of whose library three sums, each of $£ 5,000$ were voted, and sums amounting in all to $£ 43,000$ were granted for the repair of chambers and the rebuilding of the College squares. An Act was passed in William III.'s reign (ro Wm. III. 2 , c. I2) enforcing the planting of a certain number of trees in each county. In 1737 severe resolutions were passed for the protection of Fisheries. The grave abuses of the system of charging pensions on the Civil List frequently occupied the attention of the Irish Parliament. The Parliament threw itself with zeal into the establishment of a system of inland navigation by means of canals with locks, which was one of the most important events in industrial history in the Eighteenth Century. In

* See Lecky's History of England in the Eighteenth Century, VI., pp., $355-35^{8}$. 
1761 it voted a sum of $\ell_{15,500}$ to the corporations of several inland navigations, and made special grants for a canal from Dublin to the Shannon, and for improving the navigation of the Shannon, the Barrow, and the Boyne. Among the votes of the Irish Parliament for $176_{3}$ we find grants for the construction of a canal between Dublin and the Shannon, for a canal from Newry to Lough Neagh, for a canal connecting Lough Swilly and Lough Foyle, for a canal which, together with improvements on the River Lagan, was intended to complete the navigation between Lough Neagh and the sea at Belfast, and for four other inland navigations by canals.*

Lord Macartney has observed - as Chief Secretary under Lord Townshend (1767-1773) he had special opportunities of obtaining information--that for the space of fifty years from 1727 the only additional taxes imposed upon Ireland were some inconsiderable duties appropriated to the payment of the interest and principal of the debt, and some small duties the produce of which was specifically assigned to the encouragement of tillage or of some particular branch of Irish trade or manufacture (Lecky's History of England in the Eighteenth Century, II., pp. 313-314). In the last years of the Irish Parliament, and at all events from the concession of free trade in I 779 till the Rebellion of 1798 , the material progress of Ireland under the fostering care of the Irish Parliament was rapid and uninterrupted. In ten years from 1782 the exports had more than trebled. Lord Sheffield, who wrote about Irish commerce in $1_{7} 85$, said : "At present the improvement of Ireland is as rapid as any country ever experienced." At the end of the Session of 1787 , Foster, who was then Speaker, in presenting his Money Bills to the Lord Lieutenant for the Royal Assent, said :

* See I.ecky's Ieaders of Public Ofinion in Ireland, p. I88. 
" The wisdom of the principle which the Commons have established and persevered in under your Grace's auspices, of preventing the further accumulation of National Debt, is now powerfully felt throughout the Kingdom by its many beneficial consequences. Public credit has gradually risen to a height unknown for many years, agriculture has brought in new supplies of wealth, and the merchants and manufacturers are each encouraged to extend their efforts by the security it has given them that no new taxes will obstruct the progress of their works or impede the success of their speculations."* In I 790 Sir John Parnell, the Chancellor of the Exchequer, stated in Parliament that he did not think it possible for any nation to have improved more in the circumstances since 1784 . . . . than Ireland had done from that time ; the debt of the nation had decreased 696,000 , and the interest on the debt still remaining had decreased $£_{17}, 000$, which was precisely the same thing at 4 per cent. as if the principal had been reduced $€ 425,000$. "Add to this the great increase of trade, our exports alone having increased $f 800,000$ last year beyond the former period, and he believed it would be difficult in the history of the world to show a nation rising faster in prosperity." "I am bold to say," said Lord Clare, speaking of the preceding twenty years in the speech which he delivered and published in 1798 , "there is not a nation on the habitable globe which has advanced in cultivation and commerce, in agriculture and manufactures, with the same rapidity in the same period." Cooke, who was the chief official writer in favour of the Union, uses similar language. "What is meant," he asked in a pamphlet published in 1798 to advance the Union, " by a firm and steady administration ? Does it mean such an adminis-

* Lecky's History of England in the Eighteenth Century, VI., p. 354 . 
tration as tends to the increase of the Nation in population, its advancement in agriculture, in manufactures, in wealth and prosperity? If that is intended we have had the experience of these twenty years, for it is universally admitted that no country in the world has made such rapid advances as Ireland has done in these respects "*

“The Irish Parliament," writes Mr. Lecky, " was a body consisting very largely of independent country gentlemen, who, on nearly all questions affecting the economical and industrial development of the country, had a powerful, if not a decisive, influence. The lines of party were but faintly drawn; most questions were settled by mutual compromise and general concurrence, and it was in reality only in a small class of political questions that the corrupt power of the Government seems to have been strained." $\dagger$ 'The very moment Grattan achieved the independence of the Irish Parliament, Irish industries, owing to the quiet and unobtrusive work and influence of that Parliament, revived all over the land. A recent writer thus expounds this position :

"The Irish Commons did much to foster new prosperity. They could not spend large sums of money like England in promoting trades and manufactures, but the sums they did spend were wisely allotted. The industrial aspect of Ireland rapidly changed. Ruined factories sprang into life and new ones were built, the old corn mills which had ceased working so long were everywhere busy, the population of the towns began to increase, the stanciard of living among the artisan class rose, and even the condition of the peasantry changed slightly for the better. Dublin, instead of being sunk in decay, assumed the appearance of a thriving town. In

* I.ecky's History of England in the Eightecnth Contury, VI., p. 437$43^{8}$.

$\uparrow$ Ibid., p. 443 . 
fact, the independent Irish Legislature set itself to promote the material prosperity of the country in every possible way, and there is no doubt its efforts had much to say to the really surprising commercial progress which was made from 1780 until the years immediately preceding the Union. The Irish fisheries became the envy and admiration of Great Britain, and agriculture increased rapidly. Various manufactures in Ireland began to revive - the manufacture of hats, of boots and shoes, of candles and soap, of blankets and carpets, of woollens, of printed cottons, of fustians, and of glass, all sprang into importance, while the linen manufacture, which had decayed during the American War, quickly revived, and in ten years the exports of the various kinds of linen doubled."**

* A. E. Murray's History of the Commercial and Financial Relations between England and Ireland from the Period of the Revolution. 
NO'TE C.

A SKETCH OF IRISH PARLIAMEN'TARY LIFE.

ADDRESS BY MR. SWIFT MACNEILL, M.P.

Delivered before the Eighty Club in the Chamber of the Irish House of Lords, Parliament House, in September, I9II.

"IN your tour in Ireland," said Mr. Swift MacNeill, "your attention will, in the main, be directed to practical work. You will examine the present conditions of this country-conditions so changed from the year 1880 , from which this Club takes its name in commemoration of the illustrious triumph for the cause of human freedom won by Mr. Gladstone at the General Election of that year, that we may almost say that we have in Ireland a new heaven and a new earth. You will be asked to look forward with hope and confidence to a prosperous, contented, self-governed Ireland, while your hearts will be stirred to take each one a part in so glorious an achievement. To-day for a few moments I shall urge on you something different from this. I invite you to take with me a glance not at the present, but at the past. The roots of the present lie deep in the past, although we must bear in mind Lord Bacon's caution, which Lord John Russell has prefixed to a chapter on the unreformed English Parliament, and which is certainly applicable to what relates to the Irish Parliament- 
'They that venerate old times too much are lost in scorn to the new.' My main purpose is to describe to you very generally some aspects of parliamentary life in Dublin before the Union, and, above all, to give you an account of this historic building, which I love and admire more and more every day, which I have known as long as I can remember, and which was the home of the old Irish Parliament, that Irish Parliament which, despite all its defects and limitations, supplies an illustration of the value and power of the most enfeebled Parliamentary institution. You know its composition, and the restrictions to which it was subject. Of its three hundred members of the House of Commons, only one hundred and twenty-eight were selected by a semblance of popular election, while the House of Lords, which consisted at the time of the Union of two hundred and twenty-eight Temporal and twenty-two Spiritual Peers, was a body hopelessly out of sympathy with the people. The Lords Temporal were in many cases Englishmen and Scotchmen, some of whom had never been in the country, while the native Peers were men who, themselves or their predecessors, had purchased their peerages with sums of money paid to the Government to be expended on corruption of the members of the Irish House of Commons, had then become subservient Government drudges and obtained peerages, the consideration being to vote for the Government against the people in the House of Lords and to put nominees in the House of Commons in the rotten boroughs they vacated to pursue the same course. Still that Parliament, because it was a resident Parliament, repealed the Penal Lavs, freed itself from legislative control of the English Parliament, admitted the Catholic 
masses to the Parliamentary franchise, founded a seminary for Catholic priests at Maynooth, and would, had it not been destroyed by a combination of force and fraud without a parallel, have extended to all their feilow-countrymen the fullest religious and political equality.

"What the Irish Parliament did tor the material prosperity of Ireland has been testified by Lord Clare, the Lord Chancellor of the Union, speaking in support of the measure of the Union, on February roth, 1800, on the very spot on which I now stand. 'There is not,' he said, 'a nation on the face of the inhabitable globe which has advanced in cultivation, in agriculture, in manufactures with the same rapidity within the same period as Ireland in the eighteen years of her Parliamentary independence.' " [Mr. MacNeill stepped down from the rostrum to the exact spot where Lord Clare had stood. He went on]- "On the means by which the Union was carried I will not dwell. I will only remind you of the words of Professor Dicey, a protagonist for the maintenance of the Union, in his work, "The Case of England Against Home Rule': 'The remarkable tale of the transactions which carried the Treaty of Union teaches at least one indisputable lesson-the due observation of legal formalities will not induce a people to pardon what they deem to be acts of tyranny, made all the more hateful by their combination with deceit.' Standing here in the ancient Senate House of Ireland, with all its memories, this 'Old House at Home,' the spell of whose glories is throwing its splendour over the memory of us all, I say solemnly that the Irish people have never given their assent to the surrender of their Parliamentary rights, and that the authority of the United 
Parliament rests to-day, so far as Ireland is concerned, on crimes as great as that which caused the disruption of Poland. So long as a Parliament for the management of her own affairs is withheld from Ireland, although Parliaments of this character have been given, with the happiest results, to no fewer than eight-and-twenty States within the ambit of the British Empire, Ireland is the only stigmatised and degraded country under British dominion, in direct violation of every constitutional principle. The Irish claim is strengthened by the fact that the grant of responsible government to the Transvaal and Orange River Colonies, only a few years ago at war with Great Britain, which has been followed so soon by the establishment of the Union of South Africa, accentuates the denial of responsible government to Ireland, when it is remembered that Ireland had a Parliament of her own, a Parliament as old as the Parliament of England. You know, ladies and gentlemen, the Irish claim enunciated by Mr. Redmond-an Irish Parliament for the management of Irish affairs, with an Irish Executive responsible to that Parliament, and, through it, to the Irish people at large-a claim of whose success I am as certain as that to-morrow's sun will rise. The pathetic story of the old men who remembered the splendour of the former Temple weeping, while the young men rejoiced at its successor, will not be repeated, The new Irish Constitution will give to Ireland what she never had before, an Executive responsible to her own Parliament, and which will give to Ireland another inestimable privilege which she never had before, an Irish representation in the Imperial Parliament for the management of the affairs of the Empire, which has been constructed, consolidated, 
secured, extended, not merely by British, but by Irish statesmanship, genius, energy, service, and sacrifice. Having said this much on the great and absorbing question of Home Rule, I will for a few moments endeavour ta sketch in very faint outline the tone and habits and surroundings of Irish Parliamentary life before the Union, Irish Parliaments were not uniformly held in Dublin, no more than English Parliaments were uniformly held in Westminster. As in England Parliaments have been held in various places-in Winchester, in York, in Gloucester, in Oxford, so in Ireland Parliaments have often been held in places other than the capital-in Kilkenny, in Naas, in Drogheda, in Limerick. From the reign of Elizabeth, however, Dublin was the place in which the Parliaments of Ireland met. In the reigns of Elizabeth, James I., Charles I., these Parliaments were generally held in Dublin Castle, with an occasional meeting in the old Custom House or the Tholsel. From 1692 till 1728 the Irish Parliament met in Chichester House, which stood on the site of the building in which we now are. Chichester House, which was the home for upwards of a hundred years of the Irish Parliament, had in itself a strange history. It was originally designed to be an hospital, and was erected for this purpose by Sir George Carew, who succeeded Essex as Lord Deputy in the last year of the reign of Elizabeth. It was then for a few years the seat of the Courts of Law. It eventually became the Dublin mansion of Sir Arthur Chichester, who was Lord Deputy of Ireland from I604 till I6 5 . He was a native of Devonshire, who had fled from justice for the robbery of one of Queen Elizabeth's purveyors in that county. He, however, re-established his lost character by public 
robberies in this country, called, with conventional insincerity, confiscations. He eventually became the agent by which the Plantation in Ulster was caried out, and he procured enormous grants of land in that province which had been taken from the old inhabitants. $\mathrm{He}$ was the founder of the Donegall family, and through him Lord Shaftesbury, on whom has devolved by inheritance the property of that family, including, according to a recent decision of the House of Lords, all the fish in Lough Neagh, owns his vast estates in Ireland. Chichester House, having been the residence of other Lords Deputy, eventually came into the possession of the Government, and was assigned by the Crown in 1673 to be a Parliament House. Chichester House had long fallen into a ruinous condition, and had become quite unfit for the requirements of a Parliament House, and even by reason of its dilapidations dangerous to life, when at long last the Irish Parliament, having expended large sums on tempcrary repairs, determined that a fitting House of Parliament should be built on the site of Chichester House, which was demolished in December, 1728. While Parliament House was being built from 1728 till 1731 , when it was opened, the Parliament sat in the Blue Coat Hospital at Oxmanstown Green, now Blackhall Street, which was once covered by a wood, from whose timber William Rufus in 1098 had the roof of Westminster Hall constructed. You see here a curious association of the Palace of Westminster with the seat of the Irish Parliament. The architect of this building, which is unrivalled in its beauty and exquisite proportions, was himself a Member of the Irish House of Commons, Captain Edward Lovet 
Pearce, who had served with distinction in a cavalry regiment, and had then turned to the profession of an architect. He was a high-minded, honourable gentleman, to whom votes of thanks for his excellent work, which he did not live to see completed, were on more than one occasion passed by Parliament, anc grateful acknowledgments made 'for the uncommon order, beauty, and contrivance in the building,' and for the great frugality with which the money had been expended. Parliament House was not completed till 1739, while the porticoes in Westmoreland Street and Foster Place were added many years later, but the first Session in the new edifice commenced on the 5th October, I73r. Pearce died in 1733 , having been re-appointed DirectorGeneral, and having received the honour of Knighthood. No descendants of his name are now in existence, but his lineal descendant in the distaff line and his personal representative is $\mathrm{Mr}$. George Wolfe, of Forenaughts, Co. Kildare, the head of the Wolfe family, which he represented at the Quebec commemorations, and a gentleman who is as anxious for the restoration of the Irish Parliament as the descendant of the architect of the Irish Parliament House ought to be. Here is a description of Parliament House given by James Malton, an English artist of the last century, writing in 1792 :'The Parliament House of Ireland is, notwithstanding the several fine pieces of architecture since recently raised, the noblest structure Dublin has to boast, and it is no hyperbole to advance that this edifice in the entire is the grandest, most convenient, and most extensive of its kind in Europe. The inside of this admirable building corresponds in every respect with the majesty of its external appearance. The middle door under the 
portico leads directly intr the Commons' House, passing through a great hall called the Court of Requests, where people assemble during the sittings of Parliament, sometimes large deputations of them with and attending petitions before the House. The Commons' Room is truly deserving of admiration. Its form is circular, 55 feet in diameter, inscribed in a square. The seats whereon the Members sit are disposed around the centre of the room in concentric circles, one rising above the other. About I $_{5}$ feet above the level of the floor, on a cylindrical basement, are disposed 16 Corinthian columns, supporting a rich hemispherical dome, which crowns the whole. A narrow gallery for the public, about 5 feet broad, with very convenient seats, is fitted up, with a balustrade in front, between the pillars. The appearance of the House assembled below from the gallery corresponds with its importance, and presents a dignity which must be seen to be felt. The strength of the orators' eloquence receives additional force from the construction of the place and the vibration in the dome. All round the Commons' Room is a beautiful portico, which communicates by three doors with the House and to all the departments attendant thereon, which are conveniently disposed about Committee Rooms, Rooms for Clerks, Coffee Rooms. The House of Lords is situated to the right of the Commons, and is also a noble apartment. The body is 40 feet long, by $3^{\circ}$ feet wide, in addition to which at the upper end is a circular recess, 13 feet deep, like a large niche, wherein the Throne is placed under a rich canopy of crimson velvet, and at the lower end is a Bar 20 feet square. The room is ornamented at each end with Corinthian columns with niches between. On the two long sides of the room 
are two large pieces of tapestry, now (in 1794) rather decayed. One represents the famous Batt!e of the Boyne, the other the Siege of Derry. Here, again, the House assembled, from below the Bar a high scene of picturesque splendour is presented, and the Viceroy on the Throne appears with more splendour than his Majesty himself on the Throne of England.' Now Malton wrote 120 years ago, and some changes in this Chamber of the House of Lords have been made since his time. The Bar has disappeared, but we can exactly fix the place which it occupied by looking at patches in the two pillars which now fill the apertures made on either side of the House for the support of the Bar, which of course went clean across the House. The two pieces of tapestry of which Malton speaks as 'rather decayed' have not suffered in the interval of 119 years since he wrote. They are exquisite works of art, the products of the genius of the Huguenot Colony in the Liberties of Dublin, who fled to Ireland after the Revocation of the Edict of Nantes, and whose descendants we recognise in the honoured names of $\mathrm{La}$ Touche, $\mathrm{La}$ Trobe, De Lavel, D'Olier, and many others. A Mr. Baillie was employed to furnish tapestry for the House of Lords, and in July, 1728, while this Parliament House was in building, entered into a bond with the Lords Justices to make six pieces of tapestry at $£_{3}$ per ell. Of these only two-the ones we see-were perfected. The subjects of the other tour intended tapestries were the landing of William III. and his army at Carrickfergus, the entry of William III. into Dublin, the Battle of Aughrim, and the attacking of Cork and Kinsale by the Duke of Marlborough. All these historic events which were thus to be commemorated were, like the Battle of the Boyne 
and the Siege of Derry, closely associated with what may be called the politics of the Revolution, and were subjects of fierce differences of opinion which divicied Ireland into two hostile camps-the Ascendancy Party and the Catholic population of this country ground down by penal laws and reduced in their own land to absolute serfdom. The date of the tapestry is in the period when the Penal Law régime was at the very zenith of its atrocity, and the tapestries thus reflect the sentiments of the Ascendancy Anglo-Irish Parliament of the day. A friend observed to me humorously the other day that a National Parliament elected on a popular basis would make quick work with the demolition of these tapestries. I assured him he was mistaken. They will be preserved, I believe, when our Irish Parliament is re-established, with care, as interesting relics of a bygone time when the mists of strife and passion have been dissipated for ever by the sun of union between all classes and creeds of the community. This is no visionary prospect, but a certainty. Sir William Harcourt, in the House of Commons in 1895 , made the Catholic Corporation of Dublin the subject of a noble panegyric for their restoration of the statue of King William III. in College Green, once an object of angry political passion, now an old historic landmark with which every citizen of Dublin is familiar from his earliest years. We will, I am sure, preserve these tapestries. I do not think we will leave the statue of King George III. where it is, although it is a fine work of art. It was placed in 1812 , where the old Throne once was. It will be removed elsewhere to make room for the Throne from which his Majesty King George V. will open his Irish Parliament, and the old Irish House of Lords will have what it never had before, 
not one but two Thrones - the second Throne to be graced by her Majesty the Queen. This leads me to make a remark about that exquisite mantelpiece over the fireplace. It is made of Kilkenny marble. The old Irish Parliament in its worst days always encouraged native industries. When the King was visiting a great public institution in Dublin last July, an illustrious lady asked whence some marble which adorned the building had come, and was informed. 'Why,' was the quick reply, 'was it not Irish marble? Is there not excellent marble in many parts of Ireiand ?' The Chamber of the House of Lords we see, but where is the Chamber of the House of Commons? The Chamber of the House of Commons after the Union was deliberately destroyed. It is a curious and significant fact that the Government, in consenting to the sale of Parliament House to the Bank of Ireland, made a secret stipulation that the purchasers should sub-divide and alter the Chambers in which the two Houses had met so as to destroy as much as possible their old appearance. Among the Colchester papers there is a draft dispatch to Lord Pelham on the proposal of the Bank of Ireland to buy the Parliament House. At the end there is added: 'Private-I am given to understand confidentiaily that the Bank of Ireland would in such case sub-divide what was the former House of Commons into several rooms for the check offices, and would apply what was the House of Lords to some cther use which would leave nothing of its former appearance.' The secret stipulation in reference to the House of Commons was observed. The secret stipulation with reference to the House of Lords was not observed, and accordingly we can see it to-day pretty nuch as it was a century and a decate ago. 
The Government evidently feared that disquieting ghosts might still haunt the scenes that were consecrated by so many memories. Shortly after the passing of the Union, Curran, the great Parliamentary and forensic orator, a thorough anti-Unionist, was setting his watch at the General Post Office, which was then opposite the Parliament House, when a member of the House of Lords who had voted for the Union for a bribe said to him with an unblushing jocularity, 'Curran, what do they mean to do with that useless building? For my part, I hate even the sight of it.' 'I do not wonder at it, my Lord,' replied Curran, contemptuously; 'I never yet heard of a murderer who was not afraid of a ghost.'

We have seen that the Parliament of Ireland was surrounded, at least outwardly, with certainly as much splendour as the Parliament of England. On the opening of an Irish Parliament by the Viceroy it was usual for the Members of the Houses of Lords and Commons to take part in the procession from the Castle to Parliament House in magnificent coaches and in levée costumethe costume which was always worn in the Irish Parliament and in the English Parliament till the end of the second decade of the last century. Infantry lined the streets, while cavalry formed an important and picturesque feature of the Viceregal procession. On arriving at Parliament House, the Peers, being robed, awaited the advent of the Lord Lieutenant, who appeared in regal robes, attended by chief nobles bearing the Sword of State and Cap of Maintenance, and by the Lord Chancellor. The Viceroy did not wear a crown, but he wore royal robes. Till 1777 the robes worn on these occasions were the robes worn by King James II. when he opened the Irish Parliament of 1689 . He bowed to the Throne 
before he ascended it. 'The Commons were summened by Black Rod, who intimated that it was the 'pleasure' of the Lord Lieutenant-in the case of a King the intimation is that it is his Majesty's 'command' had been given-that they should attend in the House of Peers. When the Commons appeared at the Bar they were directed to elect a Speaker in their own House. Thie formalities of an election of a Speaker were precisely identical witin the formalities of the election of a Speaker in the English House of Commons. The election was at times unanimous. When there was a contest the candidates did not retire, as in the English House of Commons, behind the Speaker's Chair, but remained in the House standing at either side of the Chair. Thus when in 1771 there was a contest for the Chair, Mr. Pery, who was elected by i 8 votes against II 4 cast for his opponent, Mr. Brownlow, Mr. Pery stood at one side and Mr. Brownlow at the other side of the Speaker's Chair. 'The Speaker, with the Members of the House of Commons in attendance, on a day subsequent presented himself at the Bar of the House of Lords to receive the approval of the Lord Lieutenant, and to clemand, on behalf of the Commons, the recognition of their rights and privileges. The office of the Speaker had not then in the English or the Irish House of Commons assumed its strictly judicial character. The Speaker, like Mr. Ponsonby, who was a Treasury Commissioner, was always a political power in the House of Commons. He frequently was a large borough proprietor. He took part at times with vehemence in debates in Committee of the House of Commons. The Speaker had not an official residence, like the Speaker of the English House of Commons. He had a private 
residence in Dublin. It was the custom on the opening of a Session, other than the first Session of a new Parliament, for the Members of the House of Commons to vait on the Speaker in his private residence and accompany him in procession to the House of Commons. On fine days the Speaker, in his robes, with his train-bearer, and the Serjeant-at-Arms with the Mace, and attended by his Secretary and Chaplain, used to walk through the streets to Parliament House, and his presence was always the signal for the uplifting of hats. When the proposal for the Union was on its first introduction defeated, Mr. Speaker Foster was accorded a great ovation as he left the House of Commons. The horses were taken from his carriage, and a very serious and all but successful effort was made to tie to the carriage Lord Clare, the highly obnoxious Unionist Lord Chancellor. The salary of the Speaker was $£ 4,500$ a year, and $£_{500}$ for each Session.

" In England the Lord Chancellor is ex-officio Speaker at the House of Lords. In Ireland the offices of Lord Chancellor and Speaker were usually held by the same individual, but they were quite distinct. Lord Clare, the Lord Chancellor of the Union, was Speaker of the Irish House of Lords. He obtained a pension as an ex-Speaker of the House of Lords after the Union of $f_{3}, 978$ 3s. $4 \mathrm{~d}$., but he retained at its full salary the office of Lord Chancellor. The Chancellor's seat in the Irish House of Lords was called the Woolsack. It was a gilt chair, which was fixed below the Throne in the House of Lords, technically outside the House, and when the Chancellor, if a Peer, took part in debates he advanced a few paces so as to speak from within the precincts of the House. Irish Chancellors, like the 
English Chancellors, were not themselves necessarily Members of the Irish House of Lords. Two Irish Lord Chancellors of the early eighteenth century-Sir Constantine Phipps, the founder of the Normanby family, and Sir Charles Porter-were never Peers. They were appointed from the English Bar, and on resigning the Irish Lord Chancellorship went back to the English Bar and resumed their practice there as stuff gownsmen. The Chancellor's Chair of the House of Lords is preserved in the Royal Irish Academy. The Woolsack has become the Presidential Chair of that learned body. The Chair of the Speaker of the Irish House of Commons was, like the Chair of the speaker of the English House of Commons before I 832 , a very richly carved armchair. It was not the throne-like structure of the present Chair of the House of Commons, which has now become a fixture. At the end of a Parliament it became, as in England, the perquisite of the Speaker, and was generally regarded as an heirloom.

"The Chair of Mr. Speaker Foster, the last Speaker of the Irish House of Commons, who presided over that Assembly from 1785 till 1800 , is now in the National Museum. It is allowed to remain there, with the Mace, by the courtesy of Mr. Foster's descendant, Lord Massereene and Ferrard, who is also the owner of the Mace of the Irish House of Commons, which he has likewise deposited in the National Museum. Mr. Foster refused to surrender the bauble to any but the constituted authority by whom it had been entrusted to his keeping, and consequently it has descended to Mr. Foster's descendant and heir, the present Lord Massereene. I am not quite sure if Lord Massereene 
is a Home Ruier. I am, however, quite certain that in the new Irish House of Commons he would not refuse a request to allow the Mace and the Speaker's Chair to be restored. I ground this opinion on the fact that he has for a father-in-law our excellent friend, $\mathrm{Mr}$. Ainsworth, M.P., who sits in the Radical interest for Argyllshire, and is a thorough-going Home Ruler. Some other relics of the Irish House of Commons can still be traced. I saw a few years ago in an exhibition here in Dublin the exquisitely bound prayer-book used by the Chaplain. A magnificent candelabrum was suspended from the centre of the ceiling of the Irish House of Commons. When that Chamber was demolished the candelabrum was transferred to St. Andrew's Church, which bore in former years the same relation to the Irish House of Commons that St. Margaret's, Westminster, bears to the British House of Commons. Un the destruction of St. Andrew's Church by fire the precious relic was saved and found a place in the Examination Hall of Trinity College, where it still remains. The benches on which the Members of the Irish House of Commons sat are now in the rooms of the Royal Irish Academy, and are sometimes occupied by the Members. We are so accustomed to electric bells that we forget that in the English House of Commons before the development of electrical science there was actually one loudtoned division bell which was rung in the Lobby. What has become of this bell I know not. The destiny of the division bell of the Irish House of Commons is remarkable. It was very large, and made of silver, and its tones were singularly sweet and penetrating. It found its way into the Theatre Royal, Dublin, and was used in directing the work of the scene-shifters. 
When that theatre was destroyed by fire the bell was melted in the flames. The silver, however, was re-cast into another bell, which is, I believe, preserved in the Gaiety Theatre of this city. When the bell of the Irish House was rung for a division, the fact was instantly communicated to Daly's Club, where the Members both of the Lords and Commons largely congregated. Daly's Club occupied the site of the block of buildings between Foster Place and Anglesea Street, and the Members had ample time to be in their places. Parliament House itself, however, was well provided with means of refreshing the inner man. This is what an observer, no less acute than John Wesley, writes in his journal after a visit to the Irish Parliament: ' The House of Lords at Dublin,'

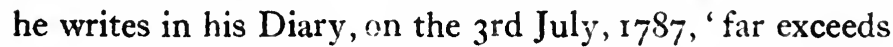
that at Westminster, and the Lord Lieutenant's Throne as far exceeds that miserable Throne so called of the King in the House of Lords. The House of Commons is a noble room indeed; it is an octagon, wainscotted round with Irish oak which shames all mahogany, and galleried all round for the convenience of ladies. The Speaker's Chair is far more grand than the Throne of the Lord Lieutenant. But what surprised me above all was the kitchens of the House and the large apparatus for good eating. Tables were placed from one end of a large hall to the other, which, it seems, while Parliament sits, are daily covered with meats at four or five o'clock for the accommodation of members.' 'There used, moreover, to be large dinner parties in the Committee Rooms. When the Union was in progress it was actually proposed by the supporters of the Union that there should be a dinner for twenty or thirty each day in one of the Committee Rooms, where they could be always at hand 
for any emergency. This idea was developed, and originated a pretended convivial society, but an actual political duelling club.

"A much more pleasing feature of the House of Commons on the social side was a time-honoured custom to which I would respectfully solicit the sympathetic attention of our revered and distinguished friend, the Speaker of the House of Commons. On the opening day of the Budget the Speaker invariably invited all the Members of the House of Commons and many members of the House of Lords to dinner. These festivities were repeated each evening until the routine Budget business had been gone through and effective work and serious discussion began. These gatherings were, of course, non-political, and political opponents and political friends temporarily forgot all differences and animosities. I have referred to John Wesley's appreciation of the Irish Parliament to show you, ladies and gentlemen, that while that Parliament was in existence it was favoured with distinguished visitors. In these days of Arbitration Treaties with the United States it will interest you to be reminded that Benjamin Franklin visited Dublin in I77I in his diplomatic efforts to secure some basis of agreement between Great Britain and the Colonies. In a letter to his friend, Thomas Cussing, written in January, I772, he gives the following account of his visit the preceding year to the Irish Parliament House : 'Their Parliament House makes a most respectable figure, with a number of good speakers in both parties, and able men of business. And I ought not to omit acquainting you that, it being a standing rule to admit Members of the Fnglish Parliament to sit, though they do not vote, among the Members, while others are 
only admitted into the gallery, my fellow-traveller, being an English Member, vas accordingly admitted, but I supposed I must have gone to the gallery, when the Speaker (Pery), having been spoken to by some of the Members, stood up and acquainted the Members that there was in town an American gentleman of character, a member and delegate of some of the Parliaments of that country, who was desirous of being present at the debates of this House, that there was a standing rule of the House for admitting Members of the English Parliament, that he did suppose the House would consider the American Assemblies as English Parliaments, but this being the first instance he had chosen not to give any order without receiving their directions. On this question the whole House gave a loud, unanimous 'Aye,' when two Members came to me without the Bar and led me in and placed me very honourably. This I am the more particular in to you, for I deemed it a mark of respect for our country and a piece of politeness in which I hope our Pariiament will not fall behind them when occasion will offer.' The Irish Parliament and the Irish people were in full sympathy with American claims, and the name of the elder Pitt, the great protagonist of American claims in the English Parliament, is preserved in Pitt Street and Chatham Street in this city, which were built at this period. Chatham was, as everyone knows, a friend of the Irish Parliament. It is not, however, so generally known that Grattan, the very greatest of Irish Parliamentary orators, and the founder in this country of a school of eloquence distinctly her own, obtained his earliest lessons in public speaking from being a diligent hearer and observer of Chatham in the English Parliament when he himself 
was serving his terms as a law student in London. The reference to the admission by courtesy of members of the English Parliament to the floor of the Irish House of Commons will render it of interest to note that a like courtesy was extended to members of the Irish Parliament in England.

"A good story in reference to this courtesy was told in a Reform debate in the Irish House of Commons by Mr. Thomas Sheridan. 'Are there not many of us,' he said, "who could not find the way to the place they represent, who never saw a constituent, who never were in a borough, who at times cannot recollect the name of it ?' He said he did not much relish or deal in anecdotes on serious subjects, but there was one which was very true and very apposite. By a courtesy of the House of Commons in England members of the Irish Parliament are admitted to hear the debates. A friend of his, then a Member, wishing to avail himself of the privilege, desired admittance. The doorikeeper desired to know what place he represented. 'What place? Why, I am an Irish Member.' ' Oh, dear sir, we are obliged to be extremely cautious, for a few days ago Barrington, the pickpocket, passed as an Irish Member.' 'Why, then, upon my soul, I forget the borough I represent, but if you get me Watson's Almanack I will show it to you.'

"Very frequently Irish Peers, as in the case of Lord Clive, who obtained an Irish Peerage on his return from India, although he was never in this country, were Members of the English House of Commons. Many noblemen were Peers both of Great Britain and of Ireland, and had seats in both Houses. Several Members of the Irish House of Commons were also Members of 
the English House of Commons. The Irish Secretary was almost invariaily a Member also of the English House of Commons, in order, if need be, to explain in that assembly the Irish policy of the Government. Thus Addison, when he was Chief iccretary in Ireland to Lord Wharton, was Member for Cavan in the Irish House of Commons and Member for Malmesbury in the English House of Commons. In your visit to Glasnevin to-day you were on classic ground. It was the residence of Addison when in Ireland, who there conversed with his intimate political and personal friends, Parnell and Swift. 'The mention of the name of Addison reminds us that the Irish Secretaryship is now filled by a gentleman (Mr. Birrell) whose name, like Addison's, will be imperishable in the literature of England. Castlereagh was one of the only Irish Secretaries without a seat, while holding that office, in the English House of Commons. He was appointed to the position not from the English but from the Irish Parliament, and his appointment was supported on the ground that, although an Irishman, he was in every respect quite unlike an Irishman. Mr. Birrell, the present Chief Secretary, has declared amid cheers in the House of Commons that his sympathies with the Irish cause are so intense that he feels as if Irish blood were bubbling in his veins. This casual allusion to the office of Chief Secretary leads me to speak of a little matter which may interest English politicians. If you were to endeavour to place a question on the paper of the House of Commons addressed to the Irish Secretary or to the Chief Secretary for Ireland, the style of that functionary would appear in the question, as corrected by the Clerks, as that of 'Chief Secretary to the Lord Lieutenant.' There was in the days of the Irish Parliament a Secretary 
of State, but the Secretaryship was made a job and a sinecure, and on one occasion given to a family named Southwell for three lives. The office of Secretary of State in later times was held by Hely-Hutchinson, a pluralist Leviathan, who is now principally remembered by the witticism of Lord North, that 'if you were to give him the whole of Great Britain and Ireland for an estate he would ask for the Isle of Man for a potato garden.' This good man was Prime Serjeant, Alnager, an officer for measuring cloth in the woollen trade, major in a cavalry regiment, Provost and Secretary of Strangford, Provost of Trinity College, Dublin, and Principal Secretary of State all in one. In this jobbery of the Principal Secretaryship the Lord Lieutenant's principal Private Secretary began to do the work in the Irish House of Commons so far back as r692. The Cabinet Minister ordinarily responsible for advising the directing of the conduct of the Lord Lieutenant was at one time the Secretary of State for the Home Department, and it is presumed that theoretically the responsibility still attaches to him, but in practice it has now devolved wholly, and, considering his somewhat subordinate title, somewhat anomalously, on our friend the Chief Secretary.

"As I have said, the Members of both Houses always attended Parliament in levée costume, and in the Houses of Lords and Commons the Lord Chancellor and the Speaker invariably appeared in their State robes. The departure on one occasion from this practice has produced a term which still lives in Parliamentary history, ' Tottenham in his boots.' In $173 \mathrm{r}$ a financial question arose about a fund which had been provided for paying the interest and principal of the National Debt. The Court Party, ever desirous of withdrawing the control of 
the finances from Parliament, desired that this sum should be granted to his Majesty, his heirs and successors for ever, redeemable by Parliament. The Opposition insisted that it should be granted in the usual constitutional manner, from session to session. The Court Party proposed a compromise, to vest it in the Crown for twenty-one years, and this proposition was put to the vote. The Members were at first equal, but at the last moment Colonel Tottenham, the Member for New Rossthe seat for which my distinguished friend, Mr. Redmond, was first returned to Parliament a century and a half later-having ridden over in haste to be present at the division, appeared in boots and in a riding attire, splashed with mud, in an assembly which then always met in full dress, and his vote turned the balance against the Government. 'The Members stared.' writes Mr. Hardy, the biographer of Lord Charlemont, himself a distinguished Parliamentarian, ' and the older ones, I have been well assured, muttered sadly and loudly at this crying innovation, as they termed it.' Tottenham is long in his grave, but the 'boots' are preserved and treasured as a precious heirloom in his family. The reference to divisions brings me to mention that divisions in the Irish Parliament, as in the English Parliament before the destruction of the Palace of Westminster by fire in 1834, were taken, not by Members going into Aye and No Lobbies respectively, but by Members voting for the affirmative of the proposition remaining in the Chamber of the House, and being counted there, while the Noes went into the Lobby, and, after the Ayes had been counted, were counted on their return to the Chamber in the face of the House and of the strangers in the Gallery. Long before Division Lists were 
published in England the lists of Members who voted Aye or No were published in Ireland, printed in red and black respectively. A memorable incident in one tateful division may be recorded of a gentleman who might well be called a real, as contrasted with a bogus, die-hard. In the Irish Parliament there were poor men. In days gone by Irish Members were paid by their constituencies, just as English Members were paid, but far more liberally. The payments ceased when Members began to pay constituencies for electing them, and, having paid for their seats, to utilise their position in Parliament not for the country but for themselves. In Ireland, till the Union, there was no Property Qualification Act debarring poor men from the House of Commons. The statute passed in England in Queen Anne's reign, and not abolished in its entirety till $185^{8}$, requiring $£ 500$ a year landed property for a county Member, and $£ 300$ a year landed property for a Member for a city and town, was extended to Ireland for the first time by the Union itself. In 1799 Mr. John Egan, a poor man, was a Member of the Irish House of Commons. He was a Member of the Bar, and was promised a Judgeship in the Superior Courts if he would vote for the Union, and threatened with dismissal from a small office, the Chairmanshin of Kilmainham, whose salary was almost his sole means of livelihood, if he ventured to oppose that measure. In 1799 the proposal for the Union was defeated. The Ayes who were in the House numbered ro6. The Noes, who were counted as they came into the House, numbered III. As Egan, who was the last to be counted, came up to the Tellers he shouted at the top of his voice 'I am III; Ireland, Ireland for ever, and damn Kilmainham.' When Egan died his entire stock-in-trade consisted of 
three shillings found on his mantelpiece. Had all acted with his honourable bluntness and 'damned the consequences,' the Irish Parliament would never have been destroyed. 'Let,' said a little bagatelle published after his death,

- Lct no man arraign him

!hat knows to save the realm he damned Kilmainham.

"I would wish to give you some further illustrations of Irish Parliamentary life, but the time does not admit of it. The ingenuity of Irish politicians in that Parliament in exposing the misconduct of the Executive was extraordinary, but one great instrument of effective opposition to the Government was overlooked, and that is the power of Parliamentary interrogation. The questioning of Ministers, which is one of the most powerful factors in the pracicice and working of the Constitution of to-day, was never, so far as I am aware, exercised in Ireland, and has only reached its prominence as a method of Parliamentary action in the British Parliament within living memory. I vould have dearly liked to have given you some account of the difference between the style of speaking in the Irish Parliament and the style of speaking at present in vogue in the Imperial Parliament-to state the reasons of their differences, to have given you some sketch of the life of the Duke of Wellington, as Mr. Arthur Wellesley, in this Parliament, and to show how his subsequent career was powerfully affected by the lessons he learned and the close and intimate friendships he formed within these walls, and to have referred with pride to the fact that Mr. Geor o Ponsonby, an Irish patriot leader in this House of Commons, was from 1807 till his death in 1816 the leader or the Opp ssition in the Englisin House of Commons- 
above all, I would have wished to describe the profound impression made on the English House of Commons by the genius, the eloquence, and the lofty character of Henry Grattan. From this I must forbear. I have, however, said enough. I do hope to arouse your sympathies, and to touch your hearts with affection for Ireland's cause and for Ireland's aspirations. I cannot but think that this occasion will be one worthy cf record in Ireland's political history. One hundred and eleven years almost to the day have elapsed since the voice of an Irish public man has been heard within this palace of Parliaments. The very last occasion on which the Irish Parliament met was on the third day of August, $180^{\circ}$, the day after the Royal Assent had been given to the Act of Union, which was to come into operation on January the first following. De Quincey was here in this very Chamber on that occasion, and has described in imperishable words, as an English visitor, with ' what unaffected sorrow and solemn wce' he witnessed the political extinction of Ireland. You, ladies and gentlemen, are here to witness, as English visitors with generous hearts, the glad sunrise of the day of Ireland's restoration to her long-lost rights and liberties. Some forty years ago Mr. Whiteside, who was afterwards Lord Chief Justice of Ireland, delivered two lectures on the Irish Parliament, at which Sir Robert Staples, Bart., Q.C., then in the advanced 'eighties, and the last survivor of the Members of the old Irish Parliament, took the chair. Referring to this Parliament House, the Lord Chief Justice said :- While we pause to admire the building we may exclaim : Could these walls speak, what might we not expect to hear ! But the passions, the hatreds, the ambitions, the sallies of wit, the flashes of humour, the 
flights of eloquence, the eager conflicts of intellects contending for fame and power, the fervid orators, the sagacious statesmen, slumber in the dust. Within these walls the voice of eloquence is hushed for ever.' The voice of eloquence has, no doubt, been hushed, but, thank God, not for ever. It will soon break forth again. Grattan was keener in his foresight than Mr. Whiteside. In his great speech against the Union he predicted accurately the period in the far distant future, which is close at hand, in which even now we may be said to live. You recollect that when Romeo descends into the tomb of Juliet he persists in believing that she still lives, and that, though prostrate in apparent death, she will be re-animated with the bloom of life. 'I do not,' said Grattan, 'give up my country. Although in her tomb she lies helpless and motionless, still there is in her lips a spirit of life and in her cheeks a glow of beauty.'

Thou art not conquer'd : beauty's ensign yct

Is crimson in thy lips and in thy chceks,

And death's pale flag is not advanced there.'

The long swoon is at an end. The Irish Parliament is coming back to life again. Be it ours to join in rolling away the stone from the sepulchre from which will emerge Ireland's native Legislature in fresh strength and beauty, a Legislature in which Ireland's sons will enact Ireland's laws on Irish soil, and will, while promoting the happiness and prosperity of their own land, unite with the British democracy, with whom they have no quarrel, in every good word and work. May Mr. Gladstone's prayer, repeated each night and morning, that the Almighty God might grant to Great Britain and Ireland the enormous favour of being joined together in a new compact, carried not by fraud or force, 
but founded on the free sanction of both peopies-a blessing withheld in his time, be not denied in ours. You desire to make us sharers in the free institutions which have made your own land so great and glorious, to give us our share in the greatest and best of all free institutions, a free Parliament representing indifferently the whole people. With such a Parliament we will gladly accept our rightful place, and join you loyally in the service of a glorious, brilliant, free and united, Empire. Our cause is a sacred one, and I say from my heart, and with deepest reverence, 'Prosper Thou the work of our hands, $\mathrm{O}$ Lord. Yea, prosper Thou our handiwork.',"

[" Perhaps," writes the Freeman's Joumal, " the most interesting incident in connection with the visit of the members of the Eighty Club was the gathering in the old Irish House of Lords on Saturlay, at noon. The visitors-all Home Rulers-were naturally anxious to inspect the Old House, but, from the mere sratification of the tourist and the politician, the arrangements happily developed into a unique function. The governors and officials of the Bank of Ireland-which is now, as everybody knows, in possession of the Irish Houses of Parliament-rose to the occasion most cordially, and not only gave the visitors every facility for the inspection of the famous building, but kindly agreed that a meeting should be held in the House of Lords, whicis has been but little altered in the last I I 1 years, and that an address on the history of tlie Irish Parliament should be delivered by Mr. J. G. Swift MacNeill, M.P., who is the greatest living anthority on the subject.

When the visitors had assembled, they were just numerous enough to fill the Chamber comfortably. The long maliogany table, with the chairs around it ; the tapestried walls, the bright and eager faces of the assemblage of ladies and gentlemen, the voice of the orator bringing into life again the names and words of Speaker Foster, Lord Clare, Grattan, and others-all touched the imagination ; and, for an Irishman, the scene was a memorable one. Mr. MacNeill spoke from a rostrum in front of the statue of George III., where the Woolsack of the Irish Lord Chancellor was formerly placed. At the beginning of his address, he said he would be a man of very steely nerves if he were able to speak in that House-the ancient home of the Irish Parliament-without emotion when he remembered that that was the very first time for III years on which 
the voice of an Irish public man had ever been heard within those walls. He wished, at the outset, on their behalf and on his own, to express his grateful acknowledgments to the Governors of the Bank of Ireland, and the other authorities of the Bank, for their courtesy in extending to them that privilege. That they should do so was a glorious sign of the times, of happy reconciliation and better understanding between all classes of the community in this country."]-Sept. 18th, 1911. 

APPENDICES. 



\section{APPENDIX I.}

THE IRISH PARLIAMENT AND THE ENGLISH

\section{PRIVY COUNCIL.}

ThE Octennial Bill whose history I have sketched presents a remarkable illustration of the failure of an attempt, often successful, of leading Members of the Irish Parliament to throw on the English Privy Council the odium of rejecting the heads of a Bill which had been sent from the Irish House of Commons in the hope that it would not be returned, or, if returned, would be so mutilated as to destroy its efficiency as a popular measure. Mr. Hardy, the biographer of Lord Charlemont, gives the following description of the reception of the news in Irish Parliamentary circles that the Septennial Bill (altered into an Octennial Bill) had been returned from England: "It is impossible," he writes, " not to mention in this place the anecdote which I heard from Lord Charlemont, as well as others. He happened at this time to dine with one of the great Parliamentary leaders. A large company, and, as Bubb Dodington says of some of the dinners with the Pelhams, much drink and much good humour. In the midst of this festivity the papers and letters of the last English Packet, which had just come, were brought into the room and given to the master of the house. Scarcely had he read one or two of them when it appeared that he was extremely agitated. The company was alarmed : 'What's the matter ? Nothing, we hope, has happened that ....' 'Happened!' exclaimed 
their lkind host, swearing most piteously. 'Happened The Septennial Bill is returned !' A burst of joy from Lord Charlemont and the very few real friends of the Bill who happened to be present! The majority of the company, confused, and, indeed, astounded, began, after the first involuntary dejection of their features, to recollect that they had, session after session, voted for this Bill, with many an internal curse, heaven knows. But still they had uniformly been its loudest advocates, and that therefore it would be somewhat decorous not to appear too much cast down at their own unexpected triumphs. In consequence of these politic reflections, they endeavoured to adjust their looks to the joyous occasion as well as they could. But they were soon spared the awkwardness of assumed felicity. "The Bill is not only returned,' continued their chieftain, 'but the Parliament is dissolved.' 'Dissolved! Dissolved! Why dissolved ?' 'My good friends, I can't tell you why or wherefore, but dissolved it is, or will be directly.' Hypocrisy far more disciplined than theirs could lend its aid no further. If the first intelligence which they heard was tolerably doleful, this was complete discomfiture. They sunk into taciturnity, and the leaders began to look in fact what they had been so often politically called-a company of Undertakers. They had assisted at the Parliamentary funeral of some opponents such as Mr. Arthur Jones Nevil, who had been expelled from the House of Commons for supposed delinquency as Surveyor-General of Public Works, of whom the Parliamentary wits said on his expulsion that he was not Inigo Jones but Outigo Jones, and now, like Charles V., though without his satiety of worldly vanities, they were to assist at their own. In the return of this fatal Bill 
was their political existence completely inurned. Lord Charlemont took advantage of their silent mood and quietly withdrew from the group of statesmen, than whom a more ridiculous, rueful set of personages in his life he said he never beheld. The city, in consequence, of the intelligence of the evening, was in a tumult of gratitude. and applause; illuminations were everywhere diffused, and our unintentionally victorious senators were obliged on their return home to stop at the end of almost every street and huzza very dismally with a very merry, very patriotic, and very drunken populace" (Hardy's Life of Charlemont, I.,pp.253-256). Mr. Fox, who was in Dublin a few years afterwards, in 1777 , where he must have heard and enjoyed this story, had probably the incident in his mind's eye when describing in the English House of Commons the iniquities of Poynings' Law.

\section{APPENDIX II.}

\section{MISTAKES IN HEADS OF BILLS CORRECTED}

\section{BY THE OPERATION OF POYNINGS' LAW.}

IN 1762 the heads of an Irish Septennial Bill sent over to the English Privy Council were submitted as usual to the English Law Officers of the Crown. They returned the heads of the Bill to the English Privy Council with the following report :

"We have examined the Act for limiting the duration of Parliaments transmitted from Ireland. So much thereof. as limits the duration to a term of seven years imparts a most essential alteration in the constitution of Ireland. The fitness or unfitness of this provision is a matter of State of so high a nature that we submit the same entirely to the wisdom of your lordships. 
"For the qualification of members we doubt how far such provisions are expedient for Ireland-whether the qualification be not too high and the exceptions too few. An amendment, however, is absolutely necessary. No member is to sit, according to the Act, till his qualification is proved, while a full House is sitting, with the Speaker in the Chair. The law, therefore, can never be executed, nor any business at all, because no Speaker can be chosen before the members have a right to vote, and no member can exercise his right of voting till such Speaker is chosen." (See Froude's English in Ireland, II., pp. ro-I r.)

\section{APPENDIX III.}

\section{POYNINGS' LAW AND IRISH PARLIAMENTARY DEPUTATIONS TO ENGLAND.}

The provisions of Poynings' Law, by which the legislative powers of the Irish Parliament were hampered and controlled by the English Privy Council, rendered necessary the sending of deputations or Commissions from the Irish Parliament to England for the purpose of conferring with the Privy Council, representing to them the wants and wishes of the Irish Parliament, and endeavouring to come to an amicable understanding and agreement with them in reference to Irish measures of a complicated and difficult character. In May, $16 \mathbf{1}_{5}$, at the time of the Ulster Settlement, Commissions were sent from the House of Commons " recommended to be charged with the affairs of the Commonwealth before the King and the English Privy Council " (Mountmorres' Irish Parliaments, I., p. 177). So, too, in 1640 , in the troublous period in the era of the War of the Rebellion, 
Commissioners were sent to England with instructions to apply to the Privy Council to secure the introciuction of a Bill in the Irish Parliament for the modification of Poynings' Law, and to obtain for the Irish House of Commons liberty to draw Bills by their own Committee during a session-the custom of the introduction of Heads of Bills was not devised till after the Revolutionasking that expensive licenses for the importation of goods be prohibited, and that the printed regulations of the Courts of Justice might be established by law. When, after the Restoration, the great transaction of the Act of Settlement of the lands of Ireland, which was drafted by Sir Heneage Finch, afterwards Lord Chancellor of England, and Lord Nottingham, was under consideration, Commissioners from the Irish Parliament were sent to London in order that the views of that assembly should be authoritatively presented to the Privy Council (Mountmorres' Irish Parliaments, I., p. 386). When, in 1782, the legislative independence of the Irish Parliament was so far established that the control of Irish legislation was limited to a discretionary power in the affixing of the Great Seal of Great Britain to a Bill which had passed both Houses as a condition precedent to its receiving the Royal Assent, deputations were seldom sent from the Irish Parliament to the English Government. In 1789, however, delegates from the Irish House of Lords and the Irish House of Commons went over to London to present an address of the Irish Parliament to the Prince of Wales (George IV.) asking him-owing to the mental aberration of the King (George III.), which, however, was merely of a temporary character-to accept the Regency with full regal powers. 
APPENDIX IV.

\section{IRISH LEGISLATION AND THE ENGLISH}

\section{PRIVY COUNCIL AFTER 1782.}

" THE old practice of submission of Irish Bills to the English Privy Council for the purpose of obtaining the Royal Assent still persisted, though this usage appears to have escaped the knowledge or notice of Irish historians. Thus, on February Ist, 1785 , it was ordered by the King in Council that a committee of thirteen members of the Privy Council, including the Archbishop of Canterbury, the Lord Chancellor, the Lord President, the great officers of State, and Mr. Pitt (but no Irish Privy Councillor or Peer), or any three of them, should be appointed a Committee to consider the Bills which shall be transmitted from Ireland during the present Session of Parliament, together with the reports to be made thereupon by His Majesty's Attorney-General and Solicitor-General, and all petitions relating thereto. And by an order at the same date is was directed that the Attorney-General and Solicitor-General (of England) should report and examine upon all Bills transmitted from Ireland and the letters from the Lord Lieutenant and Privy Council accompanying the said Bills, together with such petitions as shall be referred to them by the Lords' Committee. These references were not a mere matter of form. On March 7 th twenty-three Irish Bills were referred to the Law Officers. One of them related to the duties payable upon the importation of sugar. It was pointed out that this Bill was inconsistent with the lower duties imposed by several English Acts of Parliament, although the duties ought to be equal, and that the high duties imposed by 
the Irish Bill amounted to a prohibition of that description of sugar. But as there was no time to correct the mistake their lordships allowed the Bill to be returned, hoping that the error would be remedied by a short Bill in the next Session of Parliament. There were other cases in which the Bills were ' respited' upon the advice of the Lords of the Council. In most cases they were of course approved..... It appears, therefore, that the legislative independence of the Irish Parliament was still under the control of the Privy Council and the Law Officers, and in point of fact some of the Bills were not returned. Thus, a Bill for granting bounties on the manufacture of gunpowder was detained for various reasons set forth in a minute, and the Lord Lieutenant was recommended to have it altered (May 27th, 1785). In like manner the important Act of the Irish Parliament, entitled 'An Act for preventing doubts concerning the Parliamentary Privy Council and Officers, civil and military, on the demise of the Crown,' was respited and not returned to Ireland. The cases quoted are from the year 1785 , but similar proceedings were taken in each year during the existence of Grattan's Parliament " (The Edinburgh Review, April, r886, pp. 578-580).

\section{APPENDIX V.}

\section{POYNINGS' LAW AND JAMAICA.}

IN 1678 a measure was introduced into the Legislative Assembly of Jamaica embodying the main provisions of Poynings' Law. 'Two-thirds of the settlers of Jamaica were Irish by birth or descent, which may account for the rejection of the proposal. "In Charles II.'s time," says Mr. Long, the historian of Jamaica, "the Earl of 
Carlisle was sent here as Governor, and brought with him a body of laws fashioned after those in Ireland pursuant to Poynings' Act, with instructions to get them passed here. But the Assembly rejected them with indignation; no threats could frighten, no bribes could corrupt, no act nor argument could persuade them to consent to laws that would enslave their posterity" (Long's History of Jamaica, I., p. I I. See also ibid., pp. 15, 197-208). Sir G. C. Lewis refers to this incident in his Essay on Government of Dependencies, p. ${ }_{5} 6$.

\section{APPENDIX VI.}

\section{EDMUND BURKE AND THE IRISH CONSTI- TUTION BEFORE I 782 .}

Edmund Burke, who was Private Secretary to Single Speech Hamilton as Chief Secretary for Ireland, gives in his speech, on moving his resolution for conciliation with the Colonies, on March 22nd, 1775, the following glowing description of the Irish Constitution as it was before 1782 :

"Ireland, before the English conquest, though never governed by a despotic power, had no Parliament. How far the English Parliament itself was at that time modelled according to the present form is disputed among antiquarians. But we have all the reason in the world to be assured that a form of Parliament such as England then enjoyed she communicated to Ireland, and we are equally sure that almost every successive improvement in constitutional liberty, as fast as it was made law, was transmitted thither. The feudal Baronage and the feudal Knighthood, the roots of our primitive constitution, were 
early transmitteci into Irish soil and grew and flourished there. Magna Charta, if it did not give us originally the House of Commons, gave us, at least, a House of Commons of weight and consequence. But your ancestors did not churlishly sit down when to the feast of Magna Charta Ireland was made immediately a partaker. The benefit of English laws and liberties, I confess, was not at first extended to all Ireland. Mark the consequence. English authority and English liberties had exactly the same boundaries; your standard could never be advanced an inch beyond your privileges. Sir John Davis shows beyond a doubt that the refusal of a general communication of these rights was the true cause why Ireland was five hundred years in subduing, and, after the vain projects of a Military Government, attempted in the reign of Queen Elizabeth, it was soon discovered that nothing could make that country English in civility and allegiance but your laws and your forms of legislation. It was not English laws, but the English Constitution, that conquered Ireland. From that time Ireland has ever had a general Parliament, as she had before a partial Parliament; you changed the people, you altered the religion, but you never touched the form or the vital substance of free government in that Kingdom." The poignancy of contrast between the Irish Constitution in theory, as depicted by Mr. Burke, and in its working, must strike the student of Irish Parliamentary history. Three years after the delivery of the speech on conciliation with America, in which Burke gives this roseate description of the Irish Constitution as it was before 1782 , in a letter written in 1778 to gentlemen in Bristol he denounced, in terms which lost him his seat in Parliament for that city, the destruction of Irish industries by England. 
" Is Ireland," he asked, " united to the Crown of Great Britain for no other purpose than that we should counteract the bounty of Providence in her favour, and in proportion as that bounty has been liberal, that we are to regard it as an evil which is to be met with every sort of corrective?" (Burke on Irish Affairs, p. 261).

\section{APPENDIX VII.}

\section{“THE UNDERTAKERS.”}

“ LORD Northumberland (Lord Lieutenant from 1763 till 1765) was consigned to the care of our leaders here, as too many of his predecessors had been, for a length of time. 'These leaders were,' says Lord Charlemont, "as everyone knows, styled " undertakers," and justly were they so, as from education and from habit they were well fitted to preside at the funeral of the common weal.' Whatever their imbecility, however, in point of talents (though surely with regard to some of them at least that has been much misstated), or, however great their usurpations, their misrule, if it may be so termed, arose very naturally from the political situation of Ireland, from the situation of political parties in England, and the predominancy of one great party, the Whigs, who, at the period we now have arrived at, had ruled England with little interruption" (Hardy's Life of Charlemont, I., p. 2r7).

\section{APPENDIX VIII.}

SINGLE SPEECH HAMILTON--THE IRISH SECRETARYSHIP.-SINECURE OFFICES.

" Mr. Gerard Hamilton was as much distinguished by his speech as his silence in the House of Commons. The 
uncommon splendour of his eloquence, which was succeeded by such inflexible taciturnity in St. Stephen's Chapel, became the subject, as might be supposed, of much and idle speculation. The truth is that all his speeches, whether delivered in London or Dublin, were not only prepared but studied with a minuteness and exactitude of which those who are only used to the carelessness of modern debating can scarcely form any idea. Lord Charlemont, who had long been intimately acquainted with him previous to his coming to Ireland, often mentioned that he was the only speaker amongst the many he had heard of whom he could say with certainty that all his speeches, however long, were written and got by heart. A gentleman well known to his Lordship and Hamilton assured him that he had heard Hamilton repeat no less than three times an oration which he afterwards spoke in the House of Commons, and which lasted about three hours. As a debater he became as useless to his political patrons as Addison was to Lord Sunderland, and, if possible, he was more scrupulous in composition than even that eminent man. Addison would stop the press to correct the most trivial error in a large publication, and Hamilton, as I can assert on most indubitable authority, would recall the footman if, on recollection, any word, in his opinion, was misplaced or improper in the slightest note to a familiar acquaintance. Painful pre-eminence!"'(Hardy's Life of Charlemont, I., pp. I18-I 19).

The subordinate title of the Cabinet Minister ordinarily responsible for advising or directing the conduct of Lord Lieutenant of Ireland, whose strict official style is that of Chief Secretary to the Lord Lieutenant of Ireland, is one of many instances in the constitutional development of 
these countries in which positions, which were at first of a comparatively lowly character, have grown into great offices of State, while they have retained their former designations. Mr. Gladstone, writing in 1878 of the office of First Lord of the Treasury, usually held by the Prime Minister, to whom the Sovereign, by sign manual so recently as December, 1905 , granted place anci precedence after the Archbishop of York, says : "Nothing can be more curiously characteristic of the political genius of the people than the present position of this most important official personage. Departmentally he is no more than the first-named of five persons by whom jointly the powers of the Lord Treasurership are taken to be exercised; he is not their master, nor otherwise than by mere priority their head, and he has no special function or prerogative under the formal constitution of the office. He has no official rank except that of Privy Councillor. Eight members of the Cabinet, including five Secretaries of State, and several other members of the Government, take official precedence of him. His rights and duties as head of the Administration are nowhere recorded. He is aimost, if not altogether, unknown to the Statute Law" (Gleanings of Past Years, p. 240).

So, too, during the greater part of the last century, the great office of Chancellor of the Exchequer was not necessarily a Cabinet office, nor was the post of First Lord of the Admiralty, which has been accepted recently in exchange for that of Secretary of State for the Home Department, associated with a seat in the Cabinet till the beginning of the eighteenth century. The rise in importance of the Irish Secretaryship was owing to the reduction to a sinecure of the position of Irish Secretaly 
of State. After the Revolution, Sir Robert Southwell, the successor of Sir Isaac Newton as President of the Royal Society, had been invested with the office of Irish Secretary of State, which was granted to him for life as a sinecure. No Parliament had been held in Ireland during the interval between 1666 and 1692. Sir Paul Davis, all through the reign of Charles II., was Principal Secretary of State, and discharged in the House of Commons, as Minister, the duties of his office. The post which was given for life as a sinecure to Sir Richard Southwell was granted to his son, and then to his grandson, who died in 1755 . It was then given to Mr. Tisdal, who held the office of Attorney-General, and on his death to $\mathrm{Mr}$. Hely-Hutchinson, the Provost of Trinity College, Dublin, who held it till his death in 1794. The case of Mr. Pulteney supplies the first instance of a Secretary to the Lord Lieutenant acting as Minister in the House of Commons, and discharging the dutics of a Secretary of State. On a motion being made for the production of the accounts of the civil and military establishment and a state of the revenue, Mr. Pulteney, one of the private secretaries of Lord Sydney, the Lord Lieutenant, informed the House that the papers in question had been placed in his hands by His Excellency, and they were presented accordingly (Mountmorres' Irish Parliaments, II., p. IIO-II2; ibid., p. I86).

The Chief Secretary to the Lord Lieutenant before the Union was all but invariably a Member of the English House of Commons, who, on coming over to Ireland, was provided with a seat for a nomination borough in the Irish Parliament. He, like the Viceroy, held office at the pleasure of the English Government, and a change in that Government was followed by the resignation 
of the Lord Lieutenant and his Chief Secretary. Before the Union the Lord Lieutenant was advised by the Secretary of State for the Home Department, and theoretically, indeed, the responsibility for advising the Lord Lieutenant still attaches to him, although in practice it has devolved wholly on the Chief Secretary. The mode of communication in pre-Union times between the Government in London and the Irish Administration was by letter. The dates show that the letters took four or even five days in their journey, and that a favourable passage across the Channel would occupy some twelve hours. Writing in 1792 , Lord Mountmorres declares that there is now no necessity for the appointment, on the death of a Lord Lieutenant, as in the case of Lord Capel, who died in 1695 , of a Deputy Lord Lieutenant-a precedent which was not followed on the death of the Duke of Rutland in 1787. "The facility," he writes, "of communication now between these countries seems to make such a provision for an Executive Government almost unnecessary, as the mail goes and return's to Ireland in 120 hours, 60 to go and 60 to return, which is five days' interval, in which time the summons or notice for the meeting of the Privy Council for the appointment of a Deputy Lord Lieutenant would almost elapse, so that the King's appointment to the Lord Lieutenancy would probably anticipate the meeting of the Privy Council " (Mountmorres' Irish Parliaments, I., p. 4IO-4II).

The origin of the importance of the office of Chief Secretary to the Lord Lieutenant, which was, as we have seen, the disposal of the Secretaryship of State as a sinecure, irresistibly directs attention to the fact that great Irish offices of State were held by absentees, who took 
the salaries attached to these offices, which they treated as sinecures. Many efforts were made during the period of Irish Parliamentary independence to bring back these great offices to the country. In the beginning of the reign of George II. it was noticed that among the habitual absentees were officers of the Irish Post Office, whose salaries amounted to $£ 6,000$ a year; the Master of Ordnance, the Master of the Rolls, the Lord Treasurer and three Vice-Treasurers, the four Commissioners of the Revenue, the Secretary of State, the Clerks of the Crown for Leinster, Ulster, and Munster, the Master of the Mint, and even the Secretary of the Lord Lieutenant. Some of these great sinecure offices were bestowed on ex-Irish Secretaries, who held them long after they had severed all their connection with Ireland, as appears from the cases of Rigby and Single Speech Hamilton. The history of the great office of Master of the Rolls as a sinecure is typical of this aspect of gross scandal in Irish Administration. In the tenth year of Henry VII. the Mastership of the Rolls in Ireland was established as a judicial office. The last efficient judicial holder of the office was Christopher Wandesforde, who died in 1640, whereupon first Sir John Temple and subsequently Sir William Temple were appointed to the office, to be held as a sinecure. When, on the 23 rd February, I64I, a petition to the House of Lords was presented by Lord Lambert for the appointment of a duly qualified person to be Master of the Rolls, the Lord Chancellor informed the House of the Temple appointment. The post remained a sinecure, and two Bilis presented to the House of Lords in $177 \mathrm{I}$ and in 1783 for the purpose of making it a judicial office failed to pass (Mountmorres' Irish Parliaments, I., pp. 314-315). In 
I784 there was a curious discussion in the House of Commons on the habitual absence of the Master of the Rolls, and it was defended by FitzGibbon (Lord Chancellor Clare), who was then Attorney-General, on the very grotesque ground that it was conducive to the good administration of justice. "If the Master of the Rolls," he said, "was compelled to become a resident and efficient officer, it would render the business of the Court of Chancery more prolix and tedious than it is at present. There would be another appeal in Chancery suits, and this would be attended with great delay and inconvenience to suitors, and would give great additional reason to curse the law's delay." On the death of Rigby, in 1788 , the office was brought back to Ireland, but it was still treated as a mere lucrative sinecure, and was given to the Duke of Leinster. Immediately after the Union, the Mastership of the Rolls was re-established as a judicial office on the alleged ground of avoiding the inconvenience likely to arise from the absence of the Lord Chancellor in England. It was conferred on Sir William Smith, one of the Barons of the Exchequer, who had been raised to the Bench and made a Baronet for his services in the Irish House of Commons to the cause of the Union. The post of Lord Treasurer, which had been placed in commission in England since the reign of Queen Anne, was maintained in Ireland as a sinecure office, made hereditary in the family of the Earl of Cork, and continued to his heirs, the family of the Duke of Devonshire. The three Vice-Treasurers for Ireland only held their offices, which were also sinecures, at pleasure, but their position was one of great emolument and dignity, and it carried with it the rank of Privy Councillor in both countries. The system, however, of making lucrative sinecure 
offices, paid out of the Irish revenues, rewards for English politicians, so strongly prevailed, that the appointment of Henry Flood, the great Irish Parliamentary orator, in I775, to an Irish Vice-Treasurership, placed the administration of Lord North in very considerable difficulty with its supporters. The reduction of the great offices of the Treasury to sinecure posts extended the grave public mischief accruing from the farming out of the revenue, which was an undoubted grievance and a subject of strong protest. Amongst the instructions of the Parliamentary Commissioners to the King in 1640 was included the making of an earnest representation that the farming of the revenue be discontinued. On the 9th March, I666, a resolution was passed by the House of Commons against the farming out of the revenue of the Hearth Tax. The whole of the revenue, despite this resolution, was farmed out at first to Lord Ranelagh and subsequently to Sir James Shaen (Mountmorres' Irish Parliaments, II., pp. I40-I4I).

\section{APPENDIX IX.}

\section{AN ADROIT CHIEF SECRETARY.}

"The Chief Secretary ofEarl Harcourt, and sole Minister on whom the whole burden of public affairs lay, attended with a proportionable share of unpopularity, except during the agitation of the Absentee Tax, was Colonel (now Lord) de Blaquiere. A stranger in this country, he caught its manners, " living as they rose," or, at least, the manners of those whom he was obliged to cultivate, with peculiar and rapid discernment-he courted them, he fed them. But he knew the importance of a table, especially in this country, and distributed his best Marsoux with a very becoming profusion" (Hardy's Life of Charlemont, p. 317). 


\section{APPENDIX $\mathrm{X}$.}

\section{IF THE IRISH PARLIAMENT HAD SUPPORTED}

\section{AMERICAN CLAIMS.}

IN a letter to Lord Charlemont, dated Westminster, June $4^{\text {th, }}$ 1776, Edmund Burke deplores the opposition of the Irish Parliament, as distinguished from the Irish people, to the cause of Independence. "Your Lordship, he writes, "will think it odd that I can conclude a letter to you without saying a word on the state of public affairs. But what can I say that will be pleasing to a mind formed like yours ? Ireland has missed the most glorious opportunity ever indulged by Heaven to a subordinate State-that of being the safe and certain mediator in the quarrels of a great Empire. She has chosen, instead of being the enlister of peace, to be a feeble party in the war waged against the principle of her own liberties " (Hardy's Life of Charlemont, I., pp. 361-362). Mr. Hardy thus comments on Mr. Burke's letter, and incidentally gives an estimate of the power of the Irish Parliament on the destinies of Great Britain, in the opinion of statesmen fully competent from ripe experience to form an accurate judgment:

"What might have been the consequences at that time of Ireland acting in the manner Mr. Burke suggests, or, in other words, opposing the American War (supposing such an opposition), it is not easy to say. Could such an interference have been effected, it would, perhaps, have prevented a lamentable waste of blood and treasure, and possibly for some time longer have kept together the mother country and her colonies. Such a connection, however, could not have been permanent. The dread 
of such an interposition on the part of Ireland, and the possibility of our differing from England at some period or another, was unquestionably one of the principal arguments made use of at the time of the Union. It may not be superfluous to state what was partly said in the Irish House of Commons on the subject of the proposition that any person had an equal right with the Prince of Wales to the Regency. It never became a matter of direct debate there, but was constantly alluded to during the Regency question. . It was said, considering the possible effects of such a resolution, it was well for both countries that their Parliaments stood as they did, for their material independence might act as a material check on the possible intemperance of either, and had there been any protracted control of the Prince of Wales the independence of the Irish Parliament might shelter the people of England from the effects of party ambition, for no Minister could continue to act upon that resolution with the certainty of direct opposition to him on the part of the Parliament of Ireland. That, therefore, the independence of the two Parliaments constituted, if the phrase might be allowed, a sort of fourth estate, which would not suffer the possible occasional misconduct of either, was, in fact, the best preservative of the connection between the two countries. All this may, by those who are in the habit of disregarding Ireland, be considered as visionary, and the idea of any control at any time from the Parliament of this country laughed at as extravagant. Their general proceedings encouraged no such speculations, but I can, with truth, assert that this mode of reasoning was approved of by Mr. Burke, being assented to in private by Mr. FitzGibbon, and to the acquiescence of these two eminent men may be added 
the following historical document. It is now, I believe, very generally admitted that the Ministers, during the last four years of Queen Anne, were resolved, if possible, to bring back the son of James II. and place him on the Throne of these Kingdoms. From Ireland they expected everything, but the Parliament opposed them. Lord Midleton, a party man certainly, but a most able and upright senator and magistrate (he was Chancellor), writes in this manner of the Parliamentary proceedings in Dublin at that time: 'What effect that Session of Parliament had on the English Councils was visible in the succeeding Session of the British Parliament, at which time it was generally believed the Court intended to have brought in a Bill to empower the Queen to have appointed her successor, but the vigorous proceedings of the Irish Parliament in favour of the Protestant succession cast such a damp on these proceedings, etc.' In short, they abandoned the scheme. Such was the opinion of Lord Midleton with regard to the superior efficacy which particular conjunctures might give to the Parliament of Ireland. Let it be remembered, too, that this opinion was given, not in the heat of party or debate, but in a private letter, long after the event, to a particular friend, and never, I presume, intended to meet the eye of the public. If such, therefore, was the power of the Irish Parliament, according to Lord Midleton, at the beginning of the Eighteenth Century, when it was nothing compared to the Parliament in 1789 , it will not be said that too fond an opinion of its powers was entertained by Lord Charlemont or his friends " (Hardy's Life of Lord Charlemont, II., pp. 451-453). 


\section{APPENDIX XI.}

\section{THE IRISH PARLIAMENT AND FOREIGN POLICY.}

THE effect of the relationship between the Irish and the English Crowns on the position of Ireland as regards foreign policy has been fully and accurately described and expounded by Mr. Butt in the speech I have reproduced in the preface of this work. It is thus summed up by Mr. Lecky: "In foreign policy the position of Ireland was completely subordinate. The whole subjects of peace and war, alliances and confederacies, lay beyond her domain. . . . . She had, however, one power which might be very efficient, and also very dangerous, to the Empire. The actual participation of Ireland in the common cause could only be effected and sustained by the independent action of the Irish Parliament. If that Parliament, disapproving of the policy which led to the war, desiring to make its power felt in the only possible way in foreign policy, disliking the Ministry which made the war, and convinced that Ireland had no interest in its issue, thought fit to withhold its assistance, the Empire might, in the most critical periods, be deprived of a great portion of its strength, and Ireland, by a tacit agreement with the Empire, might be at peace, while England was at war. . . . I hasten to add that these things never occurred. Nothing is more conspicuous in the history of the Irish Parliament than the discretion with which it abstained from all discussions on foreign policy, and the loyalty and zeal with which it invariably supported England in time of war " (Lecky's History of England in the Eighteenth Century, VI., pp. 319-321). 


\section{APPENDIX XII.}

\section{A GREAT SPEAKER.}

"Mr. (LORD) PERY was, perhaps, one of the best Speakers that ever sat in the Chair of any House of Commons. His mind seemed to keep pace with every question and follow the debate in all its various forms. It was not an anxiety for a particular motion, but a general parental care of and solicitude for the well-being, the dignity of the House of Commons, and the wisdom of its deliberations. Hence, though always remembering that he was the servant of the House and not its dictator, it was perfectly easy for those who were accustomed to him, and took a part in the business, to know at once, from his looks whilst they were speaking, whether their speeches, in his opinion, gave an additional light or interest to the debate. There was no interruption, no impatience, but to make use of a dramatic allusion; he so blended himself with the entire business of the scene that an intelligent debater, by observing him, almost instantly felt where he was most right, or discovered where he was most wrong. He preserved order without encroaching on the popular nature of the House of Commons. He suffered no usurpation or Ministerial legerdemain from the Treasury Bench. The old Members were respected, the young were encouraged, all were attended to. When Mr. Fox was in Dublin during part of the winter of 1777 , he was much struck with and spoke in the most favourable terms of Mr. Pery's conduct in the Chair of the House of Commons, which he considered as a model. In private life, notwithstanding his grave and serious demeanour, no man was ever more friendly, more benign, and, to the young people, more accommodating or more pleasing, instructive and indulgent" (Hardy's Life of Charlemont, I., pp. 162-163). 


\section{INDEX.}

ABBOT, MR., $37 \mathrm{I}$.

Abercromby, Sir R., 297, 300, 3(1,3, 306.

Absentee Tax, 125, 131, 133, I40, 303.

Act of Explanation, 8 .

"for Irish Legislative Independence, 65 .

, , Legislative Union receives Royal Assent, 333.

Liberty of Conscience, 6.4 .

", of Settlement, 8, 6I, 86, I 79.

", , and Explana-

Addison, 108, 473. tion, 39, 4 I.

Adventurers Act, 8.

Africa, Trade with, 210.

Agar, Archbishop, 309, 366, 367, 368.

Ainsworth, Mr., 468.

Aix-la-Chapelle, Peace of, 84 .

Albemarle, Duke of, Io6.

Alien Act, 251.

Allegiance, Oath of, 155 .

Alinoner, Office of, 120.

Anerican Claims, 502 .

America, Trade with, 210.

American Colonies, War with, 131 , I 4 I, 147.

Amnesty, Act of, 315 .

Anabaptists, $4 \mathrm{I}$.

Anglo-Irish Colonists, I.

Annaly, Lord, I6I.

Aune, Queen, 34, 44, 72, 74, 75, 504

Arden, Mr., 108.

Armagh Address to the King, 292. 282,386 .

$$
\text { Archbishop of, } 367 \text {. }
$$

Armed negotiators, 145 .

Army Augmentation Bill, I 17.

Artizans Enigrate from Ireland, 137.
Ascendancy Party, 462.

Ashtown, Lord, 335.

Attainder, Act of, 62 .

Attorney-General, 21 .

Auckland, I,ord, I $71,263,301,321$.

Anghrin, Battle of, 461 .

Aronmore, Viscount, 199.

BACON, 17. His dictum on old timces, 454 .

Baillie, Mr., supplied tapestries for House of Lords, $46 \mathrm{r}$.

Balfour, Mr., 353, 365 .

Ball, Dr., 9, IOI.

Bank of Ireland, 463 .

Bankers and Mercliants oppose Union, 328.

Banks, Mr., 343.

Bantry Bay Expedition, $283,28 \%$.

Barrington, Sir Jonah, $310,335,339$, 343.

Barristers oppose Union, 328.

Bedford, Duke of, 91, 107,109, 370 .

Belfast, 1 57, 241, 289.

Bell used for divisions, 468,469 .

Beresford, 262, 276, 289, 301, 323 . J. C., $330,331,354$.

Berkeley, Bishop, 89 . "L Lord, ros.

Berusdorff, Count, 106.

Bessborough, Earl of, 133 .

Bethsworth, Serjeant, 406.

Bills, procedure respecting, 27 .

Birrell, Mr., 473.

Blackstone's Commentaries, 143

Blue Coat Hospital, 458.

Board of Treasury, 247.

Bolton, Sir R., 8.

Borlace, Lord Justice, 56, 62 .

Boyne, Battle of the, I 59 .

Bristol, 153,.

" Earl of, 195. 
Broderick, Speaker, 73.

Brougham, Lord, 225.

Brown, M.P. for Trinity College, 298.

Brownists, $4 \mathrm{I}$.

Brownlow, Mr., I 96, 2 I 2, 465.

Buckingham, Marquis of, 191, 221, 223, 253.

Buckinghamshire, Lord, 147,149 , I 54, 159, 168.

Burgh, Hussey, 145, 161, 163.

Burgoyne, Sir J., I 71, 297.

Burke, 37, I 33, I 53, I 56, 21 5, 253 , $262,267,384,492,502$.

Burlington, Lord, I08.

Bushe, Mr., I 66, 298, 325, 383, 388 .

Bute, Earl of, 368.

Butler, Sir R., 374.

Butt, Isaac, Speech, xiii-xxxi ; Proposal for Irish Parliament, 44 ; Settlement of Property, 45 .

Byrne, 241 .

CALDWELI, SIR J., IIO.

Callan, Lord, 368.

Calvin's Case, 3 .

Camden, I,ord, 275, 279, 285, 288, 291, 295, 297, 301, 309, 31 I, 3I $2,317,347$.

Campbell, Lord, 225.

Candelabrum in Parliament House, 468.

Canning, 344.

Carew, Sir G., 457.

Carhampton, Lord, 297.

Carlisle, Lord, I77, I 79, I81, 272.

Commissioner to American Colonies, I 7 I, I 52.

Carlow, Catholic College at, 280 .

Carrickfergus, 158.

Castlereagh, Lord, 40, 223, 31 4, 316 , $317,320,324,335,339,342$, $349,351,357,358,371,372-4$, $385,387,388,391,473$.

Catholic Convention dissolved, 246.

Catholic Emancipation, 250; last raising of question in Irish Parliament, 286.
Catholic Relief Bill passed, 246.

Cavendish, Sir H., I68.

Cease your Funning, 325.

Chair, the Chancellor's, and the Speaker's, 467, 468 .

Chamberlain, Mr. Justice, 353.

Chancellorship of Exchequer, I09.

Charlemont, Lord, $86,88,95$, IOI, $128,138,158,165,173,175$, 180, 195, I97, 20I, 229, 23I, $249,370,386$.

Charles I., 8, 34, 39, 40, 55 .

"II., Grants by, 34 ; Legislation of, 48 ; Irish Parliament of $1651,8,56,57$; False plot in reign of, 62 .

Chatham, Lord, $14 \mathrm{I}$.

Chichester, Sir A., 4, 38, 457.

Chiclester House, 458.

Chief Secretary, an adroit, $50 \mathrm{r}$.

Citizen's Journal, 93.

Clancarty, I,ord, 62.

Clanricarde, Lord, I 76.

Clare, Lord, 40, 301, 309, 320, 331, $340,343,359,386,455,466$.

Clarendon, Earl of, 38 .

Clelland, Dr., 268.

, Rer. Mr., 307.

Clifden, Lord, 367 .

Clive, Irord, 472 .

, Peerage, 31 .

Cloncurry, Lord, 326.

Clonfert, Bishop of, 369 .

Coercion Act of 1799,347 .

Coinage, debased state of, 78 ; new, $78,79$.

Coke, Lord, 3, 4, I 86.

Colchester, Lord, 371 .

$$
\text { Papers, } 463 .
$$

Cole," Lieut. -Col., 354,365 .

Colonial Trade, I32.

Commercial Code, Irish, 152.

Restrictions, 75.

Commissioners of Account, 124.

Commons, members of raised to peerage, 403 .

Congress replies to Britain's offer, I $7 \mathrm{I}$.

Connaught, 40, I 76 .

Connolly, Mr., 272. 
Constitution, Irish, 2.

Convention, The, 229 .

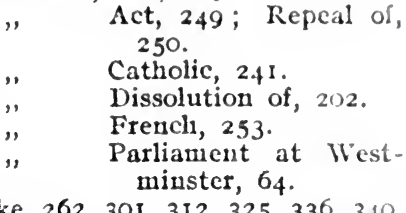

Cooke, 262, 301, 312, 325, 336, 340. $360,372,373$.

Cork, I93, 46 I.

Corn and Whiskey-making, 123.

Cornwallis, Lord, 32, I 74, 223, 273 , $297,312,316,317,320,322$, $326,330,332,340,342,346$, $350,353,358,361,362,36.5$, $366,367,368,371,372,374$, $376,386,387$.

Corruption by Government, 355357.

Corry, Isaac, 331.

" Lord, duel with Grattan, $351,392,394$.

Costumes of Members, $40 \mathrm{I}$.

Court of Claims, 42.-

Courts of Chancery, King's Bench, Common Pleas, Exchequer, 2.

Cromer, Archbishop, 49.

Cromwell : his soldiers, $4^{1}$; Régine of, $39,57,62$.

Crown Rents, 48 .

Curran, 230, 233, 290, 298; his jeu d'esprit, 464 .

Cussing, Thomas, 470 .

Customs Duties, 49, I 36 ; peculatious in, I I 5 .

DALY, Bowes, I I 7, I 45, I 78, 199. , St. George, 331 .

Daly's Club, 469 .

Darlington, Countess of, 106.

Davies, Sir J., 4, 52, 54.

De Beaufort, Duc, 95.

De Blaquiere, Lord, I 30, I 35, I 45 , 287,501 .

Declaration of Rights, 182 .

Defenders, 25I, 282, $28_{5}$.

Denmark, Queen of, 108 ; pensioned, I 28.
De Quincey, 403, 478 .

Derry, Bishop of, 195, 202, 229.

Desmond, 83 .

Destitution in Ireland, 160 .

Devoushire, Dukc of, 84,133 .

De Walmoden, Mdme, 106.

liamond, Battle of the, 282.

Dicey, Professor, 224, 455.

Differences between the Houscs, 405.

Dillon, Gerard, 63.

Dinner I'artics at Parliament House,

$$
4^{69} .
$$

, ," given by the Speaker, 470.

Disestablisiment of Irish Protes. tant Clurch, 250.

Dissenters, 22, 4l; their marriage, I 8. .

Divisions, metliods of taking, 475 , 476.

Dobbs, Mr., 350.

Dodington, ro8.

D'Olier, De I,avel, $4^{6} 1$.

Donegal family, $45 \delta$.

Dorset, Duke of, 84 .

Douglas, Chief Secretary, 252.

Down, County, 379, 380 .

Downshire, Lord, 386.

Doyle, Maior, 245.

"Drapier" letters, 79, 108.

Drogheda, 379 .

Duah, 205.

Dublin, City of, 386 .

" Corporation of, 2,8 .

Duff, Sir J., 3I5.

Duffy, Sir C. G., 54.

Duigenan, 260.

Dundas, $242,315$.

Dungannon, 175 .

Duration of Session, 4 I 4 .

Dyson, Jeremiah, 124 .

EAST INDTA COMPANY, 2 Io ; Service, 124.

Eden, Chief Secretary, Commissioner to American Colonies, I 7 I, I 79 .

Edgeworth, Miss, 268.

Edward III., 5 . 
Edward IV., 36. VI., 35, 49.

Egan, John, 476, 477.

Eighty Club, 453 .

Flizabeth, Queen, 23, 33, 35, 36, 50 .

Eilliott, Mr., 371 .

English Companies, 133 .

" manufactures tabooed, 160.

Englishmen put into important offices, 108.

Einniskillen, Lord, 317 .

Eirskine, 230.

Escheator of Munster, 365.

Exchequer, Chancellorship of the, 147.

Excise and Customs, 131 .

Explanation Act, 57 .

FAMINE of $1729,132$.

Featherstone, 374.

Fermanagh, 386 .

Peudal Tenures, Act for abolition of, 48 .

Finch, Sir H., 9.

Fitzgerald, Lord E., 316, 395.

$$
\begin{array}{ll}
, & \text { James, 33I. } \\
, & \text { Robert, 334. } \\
, & \text { T. J., 35I. }
\end{array}
$$

Fitz'’ibbon, 174, 230, 249, 256, 263 : $276,279,500$.

Fitzpatrick, Chief Secretary, I 80.

,' Colonel, I87, I 89.

Fitzwilliam, Lord, $237,253,256$, $279,282,301,303$.

Ilax, 137. Episode, 249.

Flood, Mr., 16, 501 .

" Sir F., I 8, 90, I 19, 122, 13I, $139,145,147,162,174,176$, $185,188,196,201,202,212$, $214,230,232,249$.

Foreign Policy, 505.

Forfeitures and Confiscations, 42.

Fortescue, 338 .

Foster, 167, 21 2, 276, 309, 323, 351, $390,392,466,467$.

Fox, 20, 179, I82, 192, $213,214,215$, $219,226,290,294,345,358$.

France, Rupture with, I 47.

Pranklin, Benjamin, 142 .
Freeman, Professor, his Constitutional Theory, 400 .

Free Trade. 162, 175; Riot, 163.

Freeman's Journal, Report of Meeting of Eighty Club, 480 .

French Revolution, 233, 240.

Fronde, The, 95.

Froude, 11, I30, 142, 261, 264, 273. 288.

Galway PeERAGe, 31 . , and Volunteer Associatio,n I 78 .

Gardiner, Colonel, 183 .

George I., IO4, I1 3 ; Declaratory Act, 142; Act of, Subordinates Ireland to Crown of Great Britain, 13 ; his mistresses, 106. II., 90, 104, 106, II 3 .

", III., 90 ; cognisant of bribery, 107 ; pensions, $107,113,127,128$; his indisposition, 218 ; Statue of, 462 .

Germany supplies England with sail cloths, I 37 .

Gibbet Rath, 315.

Giffard, John, 321 .

Gladstone, 294, 357, 382, 388, 453 , 479 ; Article in Contemporary Review, 388 .

Glasnevin, 473 .

Glass, Trade in, 164.

"Gold Pills for an Election," I07.

Gordon, 268.

Gordon Riots, 154.

Gormanstown, Lord, 17.

" Graces," The, 55.

Grattan, 19, 65, 83, I19, 140, I51, $156,157,162,163,166,174$, $176,177,180,184,186,201$, $203,212,214,218,220,228$, $232,234,243,246,249,254$, $265,272,279,284,293$, 298, 303, 321, 362, 370, 380, $471,478,479$; the volunteers, 171 ; proposes Vote for British Navy, 183 ; his reappearance in Parliament, 385 : duel with Corry, 392, 394 . 
Graves Peerage, 31 .

Grenville, Lord, 236, 236, 321,324 . William, 186.

Grey, Mr., 366, 378, 380, 393.

Grogan, Cornelius, 316 .

Guild of Mercliants, 386.

Habeas Corpus Act, 179. Suspended, 285 , Bill, 165,174 .

Halifax, I, ord, 98, 109, III.

IIallam, 1 I, 56 .

Hamilton, "Single Speech," $9 \mathrm{r}$, $109,494$. Sackville, 262.

Harcourt Administration, 206.

"I,ord, 127-130, 134, 1.41, $144,146,15 \%, 356$.

Sir WW., 462.

Hardwicke, Lord, 360, 369.

Hardy, 86, $94,99,128,198,370$.

Harley, 32.

Harrington, Lord, 84, 93.

Harvey, Bagnal, 316.

Hastings, Marquis of, 299.

Hawke, 233.

Heads of Bills, 26.

Hearth Money, 49.

Hely-Hutchinson, Prime Serjeant, $33,35,76,120,161,246,474$.

Hemp, Hempen Manufacture, $7 \%$, 137

Henry II., 2, 4.

, III., 3, 37 .

"IV., 5.

" V., 5.

" VI., 5 .

" VII., I 7-19, 23, 28.

" VIII., 23, 42, 80 ; Confiscations of, 48 .

Hereditary Revenue, 1 28, $212,247$.

Heron, Richard, $149,167,158$.

Hertford, Lord, 107,127 .

Hill, Sir G., 317.

Hillsborough, I,ord, 165,177 .

Hobart, Major, 235, 243 ; Catholic Relief Bill, 244.

Holland supplies England with sail cloths, 137 .

Hood Peerage, 31 .
Hooker, Mr., 91, 399.

Hotham Peerage, 31 .

Hours of Meeting, 408 .

Howe, Lady, 106.

Huguenot Colony, 461.

Hussey, Dr., 280.

INDEMNITY, Act of, 283,303, 347 331 .

Independents, 4 .

Industries (Irisli) interfered with. 137.

Insurrection Act, 283.

Ireland in the Fourth Institute, 4.

Ireton, 62.

Irish Legislation and the Englis! Privy Council after 1782 , 490.

, Parliament and American claims, 502. early struggles in for popular rights 47.

, , and the Englis'1 Privy Council, 485 .

and Foreign Policy, 505 . and Material Prosperity, 437 .

Composition of before the Union, 454.

meeting at varions places, 457 .

" Parliamentary Life, Address by Mr. Swift MacNeill, 453-48i.

, Patriot Parliament, 60.

" , Party, 143.

J ACOBNS, 380.

James I., 2, 4 ; Parliament of, 33 ; Parliamentary Opposition, 52.

" II., Proceedings of Irish Parliament declared null and roid, 10 ; Grants by, 34 ; for Liberty of Conscience, 64 ; at opening of Parliament, 464. 
" Job," description of a, I 10.

John, King, 2, 3.

Johnson, Dr., 94 ; his prediction, 388.

Juries, Grand, 182.

KEARNEY, Dr., 343.

Kendal, Countess of, 78, 106.

Kenmare, 235.

Keogh, John, 234, 24 I.

Kerry, Knight of, 359 .

Kildare, Lord, I24.

" Sheriff of, refuses obedience to Irish Court of Exchequer, 12.

Kilkenny marble, 463 .

King, Archbishop, 63.

,, Mr., 73, 359, 372.

Kingdom of Ireland, 23.

Kingsborough, Lord, I 76 .

Kingston, Earl of, 314.

Kinsale, 46I .

Knox, George, 245, 331 .

, Mr., 278, 298.

LAKE, General, 288, 297.

I,and Question, 44 .

,. thrown into pasture, 74 .

Langrishe, Sir Hercules, 38, IU8, I 19.

La Touche, 94, 154, 461 .

La Trobe, 461 .

Laurence, 346 .

Laws, CUSTOMS, USAGES, AND ETIOUETTE, 399-435.

Lecky, I30, et passim. , on Corrupt Practices, I 13.

L,inster, Conquest of, 62, , 76, 302 . Duke of, 223, 390.

Levant, Trade with, 2 IO.

Liberty against corruption, the fight for, 103.

Licences, Excise, and Customs, 49.

I,ifford, Lord, $16 \mathrm{I}$.

Linen and Cotton Manufactures, 70,124 .

Littlehales, Sir E., 3.59.

Liturgy, English, 49.

Lord Deputy, 2.
I oughborough, Lord, 182.

Lucas, C., 92.

." Iord, III.

MACAULAY, 71 .

Mace, the, $467,468$.

MacNevin, Dr., 158 .

Magna Charta, 2.

Maguan, 268, 306.

Mahou, 374 .

Malone, 25.

Malton, John, his description of Irish Parliament House, 459$46 \mathrm{r}$.

Mansfield, Lord, 186.

Manufactures, decay of, 76 ; exclusive use of Irish, 77 ; duties on, 210 ; resolution in favour of home products, 77 .

Marble, Irish, 463.

Marlborough, Duke of, 461 .

Marriages, Protestant and Catholic, IO.

Marsden, Mr., 359-361, 373.

Mary, Queen, 18, 35.

Maryborough, 38I.

Massereene and Ferrard, Lord, 467.

May, Sir E., 220.

Maynooth, 279, 455.

Membership of Parliament, Qualifi cation, Absence, Resignation, Holy Orders, Expulsion, 427.

Militia, Irish, I 39 ; soldiers transferred to the line, 387 .

Millenarians, $4 \mathrm{I}$.

Milton, Lord, 133 .

Mitford's Act, 236.

Moira, Lord, 299.

Molvneux, 65, 91, 81, 87, 73; The Case of Iveland, I I.

Money Bills, 24, 68, 90, 99, I 16 .I I 7, 122.

Monk, General, 4 I.

Moore, Arthur, 384,385 .

" Captain, 201 .

" Sir J., 297.

Morley, Lord, 2 I 5.

Mountjoy, Irord, 155 . 
Mountumorres, Lord, 22.

Muncaster Peerage, $3 \mathrm{I}$.

Munster, $173,176,3^{202}$; Settlement of, $\mathrm{C}_{2}$.

Mutiny Act, 166, 173, 174, 183.

NANTES, Revocation of Edict of, 461 .

National Debt, $76,84,147$.

National Movement, 172 .

$$
\text { , Museum, } 467 \text {. }
$$

Navigation Act, $70,216$.

Navy, British, sails made in Ireland, 137.

Neagh, I,ough, fish in, 458 .

Newenlam, Sir F., 156, 27 ().

Normanby family, 467 .

Normanton, Lord, 309, 367 .

North, Lord, 128, $132,135,152,155$; $162,210,213$; resigns, 179 , his jeu d'esprit, 474 .

Northington, Lord, 192, 196.

Nortlimberland, Earl of, 98,107, 109.

Nottingham, L,ord Chanceller, 9,57 .

Nugent, Lord, I52.

OAK, Irish, 469 .

O'Brien, Sir L., I6I.

$O^{\prime}$ Connell, I, 250, 267, 274, 305, $319,370,381,388,389,39$ ก.

O'Connor, A., $278,395$.

Octennial Bill, 95, I I $3, x_{1} 5$.

O'Donnell, Territory of, 54 .

Ogle, 260.

O'Hagan, Mr. Justice, lines by, $38 z$.

O'Neill, ' 'erritory of, 54,83 .

Orange Lodges, $386,38 \%$.

Orangemen, 328,343 ; and the Volunteer Movement, I 59.

Orange Society, 282, 285 .

Orde, 206, $214,229$.

Order, a new, proposed by rownshend, II4.

Ormonde, $56,5^{8}, 73$.

Ostmen, 2.

Outlawries of 1641 and 1688,74 .

PAIE, Landowners of the, 52, 53. Palmerston, I,ord, 108.
Parliament of 1698,59 .

duration of, inn: effect of legislation, loI ; origin of 1; composition of, 3(); and Iand System, 37 ; as affected by jublic opiniou, 67 ; sepicas. nial, 97; duration of, $98 ;$ A Sinister Administration, 127 ; etiquette of, 57 ; independence of, 78 ; opposition, 88 ; Volunteer movement, I57, 190 ; Orde's Commercial Propositions, 206; Keform and Catholic Disability, 227 ;

Catholic Emancipation, 271 ; majority for Government, 119; corrupt legislation, 282 ; hours of meeting, $407, \quad 408$; cliarges on public revenue, 413 ; Royal Assent and duratiou of session, $4^{\text {I }} 4$; Proxies and Protests, 410; Tacking, 4I2; processions on opening day, 464, 460; tone of, 433 .

, and Material Prosperity, 437.

Parnell, Sir J., 323, 331, 334, 339, $393,473$.

Parsons, I ord J ustice, 56, 233, 252, $262,272,278,284,287.29 S$, 334,384 .

Parties, the Court and Country, 86.

Pasture, Extension of, 148 .

Patrick, Saint, Order of, I15, 192.

Payment of Members, 424, 476.

Peel, Sir Robert, 360.

"Peep of Úay Boys," 251, 2 S2.

Peerage, Promotions to, 124 .

Peers, created and advanced, II 4 .

Pelham, 275, 287, 301, 326, 463 .

IN. 
Penal Code, 63, 150, 154, 235.

Pensions, 90, 132, 139 ; for Catholic Bishops, 65; struck off, 72, 106 ; increase of, 107 ; of non-residents taxed, ro6; to be reduced, 247 .

Perrot, Unveformed House of Commons, 405 .

Pery, 25, 122, I37, 161, 172, 323, $465,471,506$.

Petition, oldest Parliamentary Form, 375, 376 .

Philip and Mary, Explanation Act, 18, 19, 23, 29.

Phipps, Sir C., 75, I16, 467.

Pilkington's Case, 5 .

Pitt, the elder, $47 \mathrm{I}$.

Pitt, 35, 187, 204, 207, 211, 215, 219, $226,229,237,240,248,253$, $263,291,301,310,318,32 \mathrm{I}$, $331,340,344,351,357,363$, $37 \mathrm{I}, 373,375,378,380$.

Planting in Ireland, Act to encourage, 66.

Pledges, Parliamentary, 92.

Plunket, 298, 303, 308, 334, 376, 384,385 .

Ponsonby, I15, I 20, I 23, I25, I44, I $81,246,252,262,277,290$, $292,298,334,337,339,340$, $384,385,386,392,465,477$.

Ponsonby-Shannon Group, I 22.

Porter, Sir C., 467.

Portland, Duke of, 106, 180, 183 , $187,189,253,256,259,261$, $276,279,285,291,301,304$, $312,322,324,327,329,340$, $344,346,350,35 \mathrm{I}, 359,36 \mathrm{I}$, $362,363,367,368,371,373$, 387.

Preston, Mr., 368.

Poynings' I aw, 6, 15, 1 7-20, 22, 24 , $32,50,64,91,92,116,118,139$, $166,173,181,182,184,210$, $399,487,488,49 \mathrm{I}$.

Prayer Book, the Chaplain's, 468 .

Presbyterians, 156, 164, 233, 235, 251 .

Pretender, The, 77-81.
Prime Serjeant, Office of, 231.

Privy Councils, 19-22, 27, 32, 99, $120,123,133,156,167,174$, 183 .

Protestant and Catholic Marriages, 10.

" Church, establishment of, 50 .

Protestantism affected, 155.

Protestants flee to America, I 37. " and Roman Catholics, 33 .

Property Qualification, 97.

Proxies and Protests, 4 IO.

Prussia, Queen Dowager of, 106.

Public Works, Expenditure on, 1 IO.

Puritan Party, The, 56.

Purse, Power of the, 51 .

QUALIFICATION FOR MEMBERSHIP, 429.

Queen's County, 38I.

Questioning of Ministers, 477 .

Quit Rents, 48.

RaDsTock Peerage, 3I.

Rebellion of 1641,38 .

Redmond, W. A., 44 .

Mr., 83.

Reform Bill, I97.

Reformation, The, 49

Regency, The, 209, 218, 35I.

Reilly, Hugh, 230.

Relief Bill carried, I 56, 237.

Renunciation Act, I 85, I87, 191 .

Revenue Board, 108, I $24,125$.

$$
\text { Hereditary, } 75 \text {. }
$$

Revolution of 1688,90 .

, the French, 253, 267, 286.

Richard III., 5 .

Rigby, 26, 87, 109.

Riots of I 759,87 .

Robinson, 145 .

Roche, Sir Boyle, 196.

Rockingham, Marquis of, 1 33, 179 , I 87, I $88,191,232$.

Rodney, 233.

Rolls, Mastership of the, I 47. 
Roman Catholics, epithets applied to, 46 ; excluded from Parliament, 10.; indulgences to, 22 : Relief Act, 154.

Ross, Mr., 359, 360.

General, 332, 348, 371 .

Royal Irish Academy, 467,468 .

Rufus, William, $45^{8}$.

Russia supplies Fngland with sail. cloths, 1.37 .

Russian Troops, proposal to employ, 350.

Rutland, Duke of, 206, 207.

SACRAMENTAL Test, $156,164$.

Saint Albans, Duke of, 106.

, Andrew's Cliurch, 468.

" Margaret's, Westminster, 468.

Sandwich, I,ord, 143.

Saville, Sir George, 154 .

Scandals of Irish Administration, III.

Scotland, 267.

Scott, Attorney-General, 163 .

" Dean, 309.

", John, Farl of Clonmel, 309, 311 .

Seceders, 4 I.

Secretary to Lord Lieutenant, 473 : jobbery, $47 \%$.

Sedley, Catherine, 106.

Sessions, Annual and Biennial, 193.

Settlement, Act of, 57 .

" Cromwellian, 46.

", and Explanation, Acts of, 48 .

Shaftesbury, Lord, 458 .

Shannon, Lord, $120,125,131$.

" native Irish

Sheffield Peerage, 31 .

Shelburne, I $14,182,191$.

Sheridan, $214,264,319,331,340$, $344,346,380,472$.

Sherlock v. Annesley, 12.

Shiel, 44 .

Simnel, 17 .

Socinians, 4 I.
Soldiers on Irish Fistablishment, 114.

Somerton, Viscount, 367 .

Southwell, 108, 109, 474, 497.

Speaker of Irish Ilouse of Commons, 420,423 , $465,466$.

Spencer, Lord, 253.

I.ords, 118 .

Stainp Act, 142 .

Staples, Sir Robert, 478 .

Star Chamber and the Jommals of Parliament, 416.

Strafford, 6, 38, 55, 57, 62, 91, 266, 319.

Parliauent, 33.

Struensee, Count, 108 .

Stuart, House of Represeutation under, 34 .

Dr. William, 368.

Sugar Duty, 167.

Supply Bills, 137 .

Swift, 65, 77, 79, 86, 89, 93, :08, $160,406$.

Sydney, Lord, 16, 24, 49, 51, 68, I 16.

' TABLE of Parliamentary Patrou. age," 36 .

Tacking, $4^{12}$.

Tapestries in House of Lords, 461 , 462.

Tara, Lord, 368.

Taxation of America and Ireland, 507.

Irelaud, 359 .

Taylor, Sï Herbert, 359.

Teignmouth Peerage, 31 .

Temple, Lord, I86, 191, 275.

Theatre Royal, Dublin, 468.

Thurot, 158.

Tighe, Mr., 353, 365.

Tipperary, 381 .

Tithes, Appropriation of, 65 .

Tobacco Plant, Prohibition of, 9.

Tone, Wolfe, 233, 28r, 286.

Ione of Irish House of Parliament. 433 .

Tooke, Horme, 430 . 
Tottenlian, Colonel, "in boots," * $84,402,474,475$.

Townshend, Lord, 24, 104, 107, I I 3 , I I 4, I I6, I 19, I 2 I, I 24, I 26 , I $27-129,148,160,165,183$, I 86,356 .

Trade, Irish, Restraints on, 123.

" and Manufactures, 147 .

" of Ireland, 209.

Transubstantiation, Declaration against, 68 .

Trench, 25, 335 .

Trinity College, 468.

Tudors, The, 49 .

Tyrone's Rebellion, 42, 49.

Tyrone, Lord, 243, 334.

ULSTER, I 73, 297, $45^{8}$; plautation of, 39 ; settlement of, 52,62 ; ruin of, 137 ; Volunteer regiment, 175; under martial law, 288.

" Undertakers," 89, I04, I I 3, I20, 1 22, 127, I30, 494 .

Union, The, 75, 266, 318, 338 ; carrying through Parliament, 383-395. Act, of, 97,478 .

United Irish Brotherhood, $25 \mathrm{I}$.

" Irishmell, 234, 266, 282, $3 I I, 3 I 4$.

Upper Ossory, Iord, I33.

VICEREGAL, Government, I 27.

Vice-Treasurership, 140.

Villiers, Elizabeth, Io.

Vinegar Hill, Battie of, 155 .

Volunteer Movement, I 21 , I 38, I 50 , I $57, \mathrm{I} 75, \mathrm{I} 82, \mathrm{I} 83, \mathrm{I} 85$, $192,200,231$.

"Convention, 190, 249 .

Walsingham, Lady, 78, 106. Wandesford, Chr., 499.
Waterford, Marquis of, 334 . " Case of the Merchants of, 5 .

Wellesley, Arthur, 243, 245, 477

Wellington, Duke of, 477 .

Wesley, John, his description of the Parliament House, 469.

Westminster, Council at, 4; Parliament under Edward III., 5.

Westmorland, Lord, $217,235,242$, $254,263$.

Weston, 94 .

Wexford, outbreak in, 307.

Weymouth, Lord, I61.

Whaley. 375:

Wharton, Lord, 473.

Whiteside, 82, 21 5, 279, 478, 479.

Whitshed, Chief Justice, $77,8 \geq$.

Wickliam, Wm., 325, 359, 360 .

William III., 10, 16, 46, 70, I06, 163 ; Statue of, 462.

Windham, 253.

Wines, Duty on, $5 \mathrm{I}$.

Wolfe, Mr. George, 459.

Wollaghan Court-martial, 3 I 7 .

Wood, Wm., 78, 82 .

Woollen Trade, 10, 69, 72, 106, I64.

Woolsack, The, 466,467 .

Wright of Clonmel, brutal treatment of, 352 ; obtains damages in the law-courts, 353.

Writs of Error, 3 .

YeLVERTON, I 74, I 99, 323, 353,

$$
392 .
$$

Act, 27.

YORK, Richard, Duke of, 22, 42.

" family in Ireland, I 7 .

" and L,ancaster, 22 ; Wars of, 17 .

Yorke, Mr. 360.

Young, Mrs., 369 . 



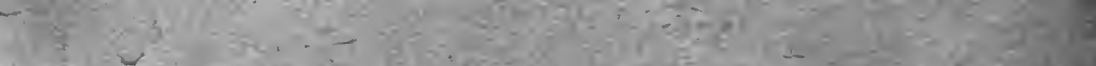

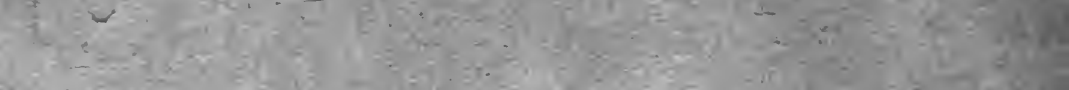
and

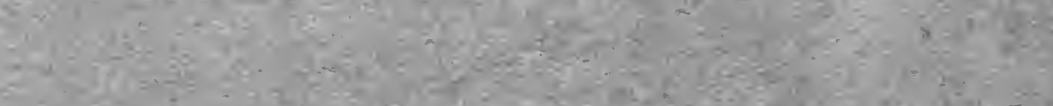

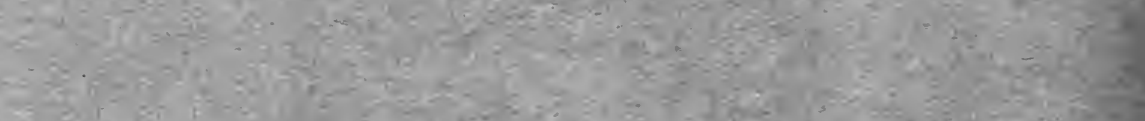

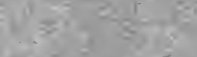

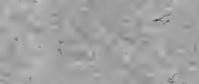
$(2 \cos 3$

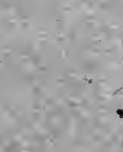

$$
\text { ain }
$$

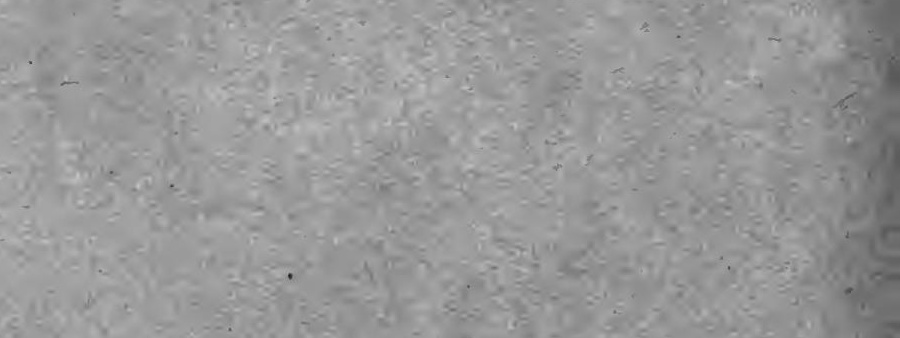

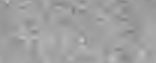

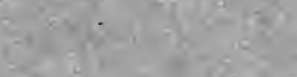

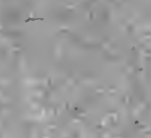

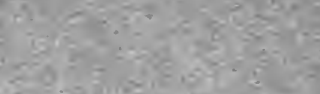


JN

1405

M33

MacNeill, John Gordon Swift The constitutional and parliamentary history of Ireland t1ll the Union

PLEASE DO NOT REMOVE CARDS OR SLIPS FROM THIS POCKET

UNIVERSITY OF TORONTO LIBRARY 
